
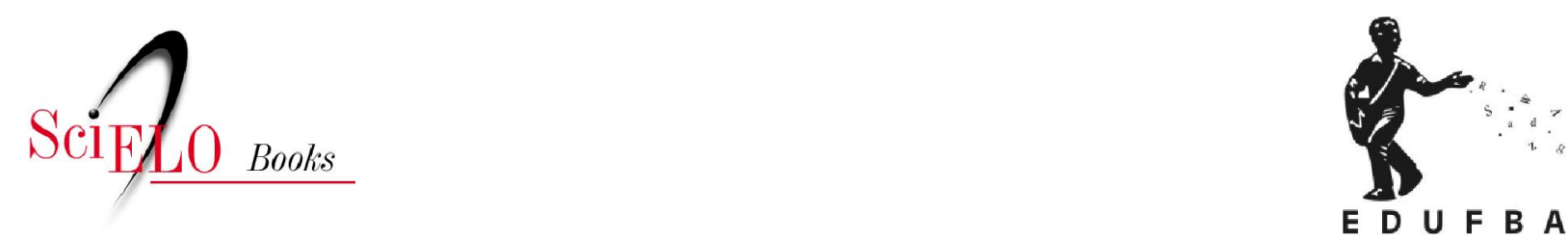

\title{
Gabriela, baiana de todas as cores
}

\author{
Sônia Regina de Araújo Caldas
}

CALDAS, SRA. Gabriela, baiana de todas as cores [online]. Salvador: EDUFBA, 2009. 272 p. ISBN 978-85-232-0933-9. Available from SciELO Books $<$ http://books.scielo.org $>$.

\section{(1) (1) $\Theta(9)$}

All the contents of this work, except where otherwise noted, is licensed under a Creative Commons Attribution-Non Commercial-ShareAlike 3.0 Unported.

Todo o conteúdo deste trabalho, exceto quando houver ressalva, é publicado sob a licença Creative Commons Atribuição Uso Não Comercial - Partilha nos Mesmos Termos 3.0 Não adaptada.

Todo el contenido de esta obra, excepto donde se indique lo contrario, está bajo licencia de la licencia Creative Commons Reconocimento-NoComercial-CompartirIgual 3.0 Unported. 
Gabriela, Baiana de Todas as Cores 
UNIVERSIDADE FEDERAL DA BAHIA

Reitor

Naomar Monteiro de Almeida Filho

Vice-Reitora

Francisco José Gomes Mesquita

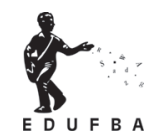

EDITORA DA UNIVERSIDADE FEDERAL DA BAHIA

Diretora

Flávia Goullart Mota Garcia Rosa

Conselho Editorial

Titulares

Ângelo Szaniecki Perret Serpa

Caiuby Alves da Costa

Charbel Ninõ El-Hani

Dante Eustachio Lucchesi Ramacciotti

José Teixeira Cavalcante Filho

Alberto Brum Novaes

Suplentes

Antônio Fernando Guerreiro de Freitas

Evelina de Carvalho Sá Hoisel

Cleise Furtado Mendes

Maria Vidal de Negreiros Camargo

\section{Apoio:}

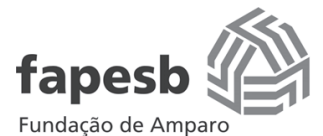

à Pesquisa do Estado da Bahica

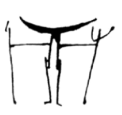

Fundação Casa de Jorge Amado 


\section{Gabriela, Baiana de Todas as Cores}

as imagens das capas e suas influências culturais

Sônia Regina de Araújo Caldas

Salvador -Bahia 2009 
(C)2009, by Sônia Regina de Araújo Caldas

Direitos de edição cedidos à EDUFBA.

Feito o depósito legal.

Capa e Projeto Gráfico: Angela Garcia Rosa

Revisão: Solange Fonsêca

Tratamento de imagens: Rodrigo Schlabitz

Sistema de Bibliotecas - UFBA

Caldas, Sônia Regina de Araújo.

Gabriela, baiana de todas as cores / Sônia Regina de Araújo Caldas ; apresentação Myriam Fraga, Lícia Regina Carvalho Moreira de Souza. - Salvador : EDUFBA, 2009.

272 p. : il.

Originalmente apresentada como tese do autor (doutorado - Universidade Federal da Bahia, 2003)

ISBN 978-85-232-0649-9

1. Capas de livros. 2. Imagens - Interpretação. 3. Análise do discurso. 4. Comunicação e cultura. I. Fraga, Myriam. II. Souza, Lícia Regina Moreira de. III. Título.

CDD - 401.41

Editora filiada à

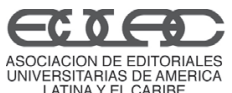

LATIARIAS DE AMERICA

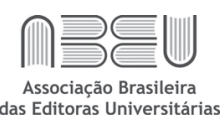

das Editoras Universitárias
$\mathrm{CBaL}$

EDUFBA

Rua Barão de Jeremoabo, s/n, Campus de Ondina,

40170-1।5, Salvador-BA, Brasil

Tel/fax: (7I)3283-6I60/3283-6I64

www.edufba.ufba.br | edufba@ufba.br 
Com todo o carinho e amor:

Aos meus pais José Joaquim Borges de Araújo Filho (in memoriam) e Risolêta Lopes Pontes de Araújo pela luz que me indicou o caminho do livro.

A Oberdan, meu namorado, pelo amor, companheirismo e comunhão sempre. Aos meus queridos filhos Pablo e Rodrigo, por fazerem a minha vida ter um sentido novo a cada dia. 


\section{Prefácio}

No universo de estudos sobre a obra amadiana, muitos deles já reunidos no acervo da Fundação Casa de Jorge Amado, a presente publicação emerge como um importante testemunho de como a obra pode ser recebida em contextos dos mais diversificados.

De autoria da pesquisadora e professora, Sonia Regina Caldas, o ensaio "Gabriela, baiana de todas as cores", resultante da tese de doutorado defendida em agosto 2003, na UFBa, vem, certamente, cumprir o papel de proporcionar aos estudiosos de literatura uma visão pormenorizada das ilustrações e das capas de várias edições do romance "Gabriela, cravo e canela", no Brasil e no mundo.

A Fundação Casa de Jorge Amado, que tem como finalidade preservar, organizar, manter e divulgar o acervo documental de seu patrono, vem procurando, desde a sua criação em julho de 1986, incentivar estudos e pesquisas sobre o universo amadiano na certeza de assim estar contribuindo para melhor compreensão e reconhecimento de sua obra, especialmente perante as gerações futuras.

Nesse viés, a Fundação se tornou um expressivo centro de produção cultural e editorial, mantendo vínculos com instituições representativas nacionais e internacionais.

A Divisão de Pesquisa e Documentação, constituída de cerca de 250.000 documentos, busca atender às múltiplas demandas de utilização do acervo, através de projetos específicos sobre literatura e cultura, apoiando desse modo inúmeras pesquisas que resultaram em alentada produção científica.

O grande desafio é promover incessantemente um canal de experiências e de intercâmbios culturais, incentivando e sistematizando a produção de estudos, teses e ensaios realizados a partir da obra amadiana, contribuindo dessa maneira 
para a divulgação de novas idéias e conceitos, estimulando a formação de uma consciência quanto à importância da literatura para a fixação de uma memória cultural.

Desse modo acreditamos que a presente publicação, além do objetivo específico de trazer à tona aspectos inusitados sobre o universo das capas e ilustrações nas diversas edições dos livros de Jorge Amado, através da cuidadosa e extensa pesquisa da professora Sonia Regina Caldas, terá o condão de ampliar o catálogo institucional de estudos e pesquisas, elaborados em torno das obras deste grande escritor baiano, produzidos a partir de documentos do acervo que ele deixou como legado de uma vida inteiramente dedicada à literatura.

Salvador, 30 de julho de 2009.

Myriam Fraga 


\section{Apresentação}

Não sei se ouvi ou li em algum lugar, mas a memória registrou. "Como saber o valor do presente sem desembrulhar o pacote?" e Sônia Regina oferece aos leitores sua "Gabriela, Baiana de Todas as Cores", presente que traz implícito um grande desafio: como desembrulhar esta Gabriela que vem, há cinquenta anos, viajando pelo mundo e fazendo girar ao contrário as rodas e engrenagens do progresso?

Este livro que me foi dada a honra de apresentar, distinção de uma ex-aluna da Análise do Discurso, é um espaço de reflexão e um movimento de pensamento, aberto ao diálogo, para discussão de como a linguagem das capas de Gabriela, Cravo e Canela das edições brasileiras e estrangeiras funcionam no processo de produção de sentidos dos leitores de diferentes culturas.

Assim construiu com maestria seu objeto de estudo e com extrema lucidez, deslizando entre a "luz e a sombra", apresenta a leitura do discurso de quarenta e oito capas do livro Gabriela, Cravo e Canela, mostrando sua interferência no "encontro do leitor com o discurso de origem" pela representação plural da personagem. Estas representações de Gabriela, a pluralidade de tipos e modelos, como escreveu a autora, "podem estar enriquecendo-a mediante a possibilidade de uma modificação infinita..."

Será que a Gabriela, do inesquecível Jorge Amado, cobiçada por tantos olhares, não é representação do bem-estar subjetivo das experiências de vida dos "não-civilizados", uma possibilidade de resgatar a condição humana, ameaçada pela privação de prazeres e amarrada à racionalidade que exige pensar antes de agir? Não estaria Gabriela entre os seguidores de Epimeteu (mito recriado e interpretado pelo filósofo renascentista Francis Bacon) que satisfazem a sua índole e preferem fruir o prazer do instante, imersos na pura alegria instintiva de viver? 
Estes discursos que embalam e porque não dizer embrulham Gabriela são provocativos, instigantes e abrem um novo campo de questões sobre o conhecimento da linguagem, sujeitos e sentidos.

Ao leitor caberá a produção de sentidos, ao atravessar este arco-íris de cores múltiplas e cambiantes e as divergências de representações desta misteriosa e indecifrável Gabriela.

Salvador, 31 de agosto de 2009.

Lícia Regina Carvalho Moreira de Souza 


\section{Sumário}

Um tom pessoal $\quad 13$

Qual a cor, afinal? $\quad$ I5

a $L u z \quad 18$

$\begin{array}{lr}\text { A luz e o livro } & 19\end{array}$

A sombra e a interdição $\quad 27$

A refração e a composição $\quad 29$

Os pigmentos e a obra literária 31

as Tintas da Paleta $e$ o Discurso das Capas 40

A mistura e a construção 4 I

O verniz e a sedução $\quad 52$

A harmonia e o contrato 56

O contraste e a censura 7।

as Cores Originais e as Capas Brasileiras 80

Primeira capa 81

$\begin{array}{lr}\text { Segunda capa } & 99\end{array}$

$\begin{array}{ll}\text { Terceira capa } & 107\end{array}$

Quarta e quinta capas $\quad 115$

$\begin{array}{ll}\text { Sexta e sétima capas } & 129\end{array}$

$\begin{array}{ll}\text { Oitava capa } & 145\end{array}$

Nona capa $\quad 153$ 
as Cores Terciárias e as Capas Estrangeiras

Primeira capa estrangeira

Segunda capa estrangeira

Terceira capa estrangeira

Quarta capa estrangeira

Quinta capa estrangeira

205

Sexta capa estrangeira

211

Sétima capa estrangeira

Oitava capa estrangeira

223

Nona capa estrangeira

a Propagação da Luz e os Efeitos Culturais 


\section{um Tom Pessoal}

Inicialmente, despontou um grande interesse em perceber as influências da linguagem não-verbal impressas nas capas de livros, consequentes dos questionamentos da pesquisadora de Semiótica e Análise do Discurso publicitário, da professora de Produção Gráfica e da Artista Plástica, posteriormente uma monografia apresentada ao Curso de Análise do Discurso na UCSAL na qual foram analisadas duas capas do livro Gabriela, Cravo e Canela; e, a seguir, a curiosidade de analisar outras capas, que provocou uma tese de doutorado defendida em agosto de 2003, na UFBA. Estes foram os matizes que formaram a cor final deste livro.

Para esta edição, fiz algumas modificações no sentido de produzir um texto que contribuísse para os estudos da análise do discurso não-verbal e das embalagens - capas e principalmente para a percepção da diferença entre uma boa obra literária e um bom produto no mercado editorial.

Em particular, agradeço às generosas orientadoras, professoras Lícia Regina Souza e Joselice Macedo, pela semente na teoria da análise do discurso, a Ívia Iracema Duarte Alves, pelo convite para fazer parte do seu projeto intelectual e pelo incentivo à pesquisa dos estudos culturais, assim como a Beth Brait, pela contribuição nos discursos e análises. Agradeço também a João Santana Neto, pela parceria nos estudos da semiótica e análise do discurso, a Maria José Passos, Bohumila Araújo, Gerald Morris, Lícia Pedreira, Carmem Medeiros e Silvia La Regina, pelo prazer compartilhado das descobertas nas traduções, a Solange Fonsêca e, mais uma vez, a Lícia Regina Souza, pelas revisões e adaptações.

Devo também mencionar meus agradecimentos, a FAMETTIG, UCSAL e FAPESB, pelo incentivo, a Myrian Fraga e aos funcionários da Fundação Casa de Jorge Amado por tornar possível este trabalho, fornecendo a matéria-prima. 
Sou grata, ainda, a EDUFBA, especialmente as professoras Flávia Garcia Rosa e Diana Tourinho, pelo interesse e incentivo, e a todos aqueles que colaboraram, em diferentes instâncias, para a realização deste livro.

Não poderia esquecer de agradecer a provocação constante dos meus alunos, partículas de luz, que constituem o mais fiel reflexo dos diversos fluxos luminosos da educação. 


\section{Qual a Cor, Afinal?}

Este estudo surgiu de uma conversa sobre que idéias as ilustrações e capas das várias edições passam para os leitores do romance Gabriela, Cravo e Canela. $\mathrm{Na}$ discussão proposta como pesquisa para a elaboração, inicialmente, de uma monografia e posteriormente de uma tese' ${ }^{\prime}$, foram observadas a construção e a leitura das imagens culturais da baianidade e, por ilação, nas capas estrangeiras, os ícones que sugeririam o imaginário do Brasil e do seu povo.

Como a pesquisa fez parte de um projeto maior ${ }^{2}$, este trabalho tentou responder a questão central do projeto: Seria possível um autor que circula entre a alta literatura e a literatura popular (tirando suas ferramentas das duas e articulando-se com a mídia), ser um autor que lê o Brasil e dá uma resposta alternativa a nosso descalabro e a nossa inferioridade com relação ao centro do mundo (países centrais)? Também outras hipóteses foram levantadas: Pode-se ler a ficção amadiana como uma interpretação da Bahia? Os livros de Jorge Amado fazem, apenas, a leitura da Bahia? Como a Bahia é lida? Baianos e estrangeiros a lêem da mesma maneira? Os críticos de outras culturas e mesmo de outras regiões do País lêem a Bahia como uma região exótica? A identidade baiana representa uma via de mão dupla (positiva e negativa) que pode estar influindo na análise e nos julgamentos dos críticos brasileiros e estrangeiros? Os livros de Amado fazem a leitura do Brasil?

Diante dessas indagações, chegou-se à definição do corpus objeto deste estudo. A partir da percepção de que o livro é uma mercadoria como as outras, dado o seu aspecto "nobre", e considerando suas origens e finalidade, observaram-se várias modificações gráficas importantes em cada edição. A partir dessas constatações, levantou-se a hipótese de que estas modificações influenciariam na dialogicidade da obra literária com o leitor e, conseqüentemente, no reconhecimento profissional de Amado. Com essa perspectiva, procurou-se observar como a obra literária Gabriela, Cravo e Canela, expressão de uma cultura, vem sendo mostrada através do discurso das capas e como aparecem as fissuras de sentido devido às diferentes condições de leitura.
Tese de doutorado Gabriela baiana de todas as cores, de autoria de Sônia Regina Caldas, aprovada pelo Instituto de Letras da UFBA (2003).

2 Projeto sobre Jorge Amado, sob a responsabilidade da professora doutora Ivia Alves, UFBA. 
Em muitas ediç̧̃es, a única ilustração da narrativa estava nas capas dos livros, e Amado, na maioria das vezes, não tinha nenhum conhecimento sobre o lay-out, que fica sempre a critério das editoras. Dada a importância da capa como embalagem de um produto, verificou-se que esta, como rotulagem da obra Gabriela, cravo e canela, era modificada em edições nacionais e, radicalmente, em algumas edições estrangeiras, alterando o enfoque, a depender dos interesses editoriais.

Rótulo é qualquer informação impressa na embalagem para identificação do produto e, sendo a capa também um discurso publicitário, com o objetivo de levar o observador-leitor ao consumo, este discurso foi analisado no romance Gabriela, cravo e canela, para investigar como vêm funcionando essas embalagens e suas conseqüências para o trabalho amadiano. A escolha do livro partiu de uma seleção prévia do projeto, por ser a primeira obra de Amado a ter uma vida mercadológica mais intensa, que possibilitou ou reiterou o lugar do escritor no cenário literário e cultural do País e, inclusive, no internacional.

Gabriela, Cravo e Canela teve sua primeira publicação em 1958, sendo definido pelos críticos como um romance que denuncia as injustiças sociais e políticas, perspassando por uma história de vida cotidiana, cheia de preconceitos, falsos moralismos com relação a sexo, amor e casamento. As diversas personagens femininas que conduzem os episódios, nesse romance, expressam a luta pela libertação da mulher, exaltando a simplicidade do cotidiano na cultura baiana.

Várias edições do romance foram encontradas no acervo da Fundação Casa de Jorge Amado, no total oitenta e duas edições (entre brasileiras e estrangeiras). A pesquisa foi ampliada em bibliotecas, livrarias, sebos e pela Internet, entre outras fontes. Inicialmente, as edições brasileiras foram separadas das edições traduzidas em países ocidentais, cuja cultura nos é mais próxima, como também das capas impressas em países orientais. Posteriormente, foi feita uma subdivisão de acordo com algumas especificações regionais e culturais. Este trabalho de observação do corpus conduziu à seleção de quarenta e oito capas, sendo selecionadas para análise nove capas brasileiras e nove capas estrangeiras.

Os critérios e as implicações para a análise dos discursos foram: a origem das capas, data da edição, autoria, técnica artística usada na ilustração e informações que poderiam promover uma aproximação com as condições de produção do autor da capa e com a cultura local. Foram ainda contempladas a situação do contexto social no momento de lançamento da edição e uma resumida biografia dos ilustradores, ou de quem assinava a capa, apesar de, na maioria das vezes, não ter sido encontrado registro destes profissionais nas edições, fato que sinaliza para uma falha dos editores. 
É importante registrar que cada publicitário, ou programador visual, ou ainda capista (como são rotulados na maioria das vezes), utilizava as linguagens verbal e não-verbal e textos de autorias diferentes para compor o seu discurso.

Como instrumental teórico para a leitura dos discursos foram escolhidas as teorias da análise do discurso, da semiótica, e as que embasam o mercado e a publicida$\mathrm{de}^{3}$. Determinado isso, resolveu-se relacionar o livro com um dos sentidos que este possui, que é o de "luz" para a humanidade, e estabeleceu-se um diálogo entre o livro e a cor, como produto da luz, para fazer ver as múltiplas cores da Gabriela.

Esta obra é constituída dos seguintes capítulos: A LUZ, que se refere ao livro e suas capas, abordando o histórico, tomando-o como luz para a humanidade, e a importância da luz para a percepção da cor.

O segundo capítulo aborda AS TINTAS DA PALETA E O DISCURSO DAS CAPAS, observando-se como as tintas que foram escolhidas pelo capista, vão imprimir sua idéia, seu pensamento, sua interpretação, como funciona o discurso das capas e qual o seu efeito publicitário.

O terceiro capítulo, AS CORES ORIGINAIS E AS CAPAS BRASILEIRAS, faz uma leitura das capas brasileiras como as mais próximas do contexto cultural descrito por Amado, de forma semelhante à descrição das cores originais ou naturais de um determinado local como as mais fáceis de serem identificadas e reconhecidas.

No quarto capítulo, denominado AS CORES TERCIÁRIAS E AS CAPAS ESTRANGEIRAS, é estabelecida uma relação entre as cores formadas por uma cor primária e outra secundária com uma terceira "cor", como o processo utilizado nas capas estrangeiras, resultado de uma leitura dos capistas de uma provável edição brasileira, na qual eles captaram as informações não somente do texto amadiano, como fonte primária, mas também da tradução e da ilustração da capa da edição lida, como segunda informação.

No quinto capítulo, A PROPAGAÇÃO DA LUZ E OS EFEITOS CULTURAIS, é feita uma reflexão sobre o que essas capas provocariam nos observadores-consumidores e possíveis leitores ao adquirir a obra.

Trata-se de um trabalho de análise dos processos constitutivos dos vários tipos de linguagem, dos efeitos de sentido, das ideologias infiltradas, da influência das ilustrações e do dialogismo com o público-alvo das diferentes culturas. $\bigcirc$ conjunto desses textos fica à disposição dos leitores, como sugestão para uma reflexão sobre os processos de produção de sentidos e de como aquilo que parece ser evidente ou sem-sentido se entrelaça, se transforma e pode estabelecer novos gestos de interpretação.
Tendo em vista essa conclusão, foram escolhidos como âncoras para a análise do discurso os autores: Michel Pêcheux (1990), Dominique Maingueneau (1997, 1998), Mikail Bakhtin (1988, 1995), Beth Brait (1996, 1997), Eni Pucinetti Orlandi (1987, 1993), Helena Nagamine Brandão ( 1997 1998, 1989). Para as análises semióticas, foram utilizados os estudos e as afirmações de: Umberto Eco $(1993,1997)$

Roland Barthes (1987), Aléssio Ferrara (1993, 1997) e, especialmente, o discurso não-verbal ancorado nas reflexões de RudolfArnheim (1992), Jacques Aumont (1995), Israel Pedrosa (1982), John Berger (1972) e M. Massironi (1982), que estudam as leis da forma, as cores e o sentido das imagens.

Para a leitura do discurso publicitário e suas implicações, o estudo se apoiou nas afirmações de: Jesus Martin-Barbero (1997), Sal Randazzo (1996) e Jean Baudrillard (1968), a fim de serem mapeados, delineadose comparados as diversas culturas e seus imaginários, receptáculos e préconstruídos. Foram utilizadas, ainda, as abordagens de: Edward Said (1990, 1993),

Néstor García Canclini (1998), Homi Bhabha ( 1998), Roberto Reis (1995, 1998), Renato Ortiz ( 1995), Franz Fannon ( 1983), Fredrich Jameson ( 1994$)$, Benedict Anderson (199I) e Michel Foucault (1979), entre outros, a fim de tentar inserir as capas nos seus respectivos contextos geopolíticos. 
"A história do homem ocidental é, em última análise, a história do livro."

Wilson Martins

"Aleitura é sempre apropriação, invenção, produção de significados."

Roger Chartier 


\section{a Luz e o Livro}

A luz branca que provém do Sol é a principal fonte luminosa com a qual o homem lida. Esta luminosidade é, na verdade, a mescla de luzes que contêm comprimentos de ondas diferentes, cuja mistura na retina do olho humano vai permitir a sensação de várias cores. Assim, a percepção visual é o processamento, em etapas sucessivas, de uma informação que chega ao olho humano por intermédio da luz. Portanto, existem cores e imagens porque existe luz, e a percepção visual é a relação entre o homem e o mundo que o cerca.

Logo, não existem cores "reais", pois o que a percepção humana capta são vários comprimentos de onda que compõem a luz, os que são absorvidos e refletidos pelos objetos que estão à sua volta. As cores percebidas por cada indivíduo vão depender dos fatores perceptivos, psicológicos e culturais. A imagem percebida dependerá da capacidade fisiológica do globo ocular de quem olha, e as sensações dependerão das influências psicológicas na sua experiência de vida e do significado ou simbolização de cada objeto na cultura em que esse indivíduo convive.

Nesse sentido, é a luz que faz o homem perceber as coisas, pois sem luz nenhuma imagem ou cor seria vista, sendo o livro, por sua vez, "luz" que dá horizonte cultural ao meio social, permitindo a disseminação do conhecimento para a humanidade. Sob esta perspectiva, procurou-se estabelecer uma relação entre o livro como "luz" que transmite o conhecimento e a verdadeira luz, que dá origem à percepção visual das imagens e das cores.

A leitura de um livro pode ser relacionada com a percepção da cor, considerando que ambas podem sofrer influência dos matizes. Na percepção da cor, os matizes seriam os comprimentos das ondas de luz que fazem ver cores diferentes, 
e na leitura do livro, poderiam ser os múltiplos sentidos dados ao texto pelo leitor, de acordo com a sua visão de mundo.

A cor, como reflexo da luz, não tem existência material, assim como o que foi narrado no romance Gabriela, Cravo e Canela também não tem existência real, sendo, por isso, chamado de ficção. $\bigcirc$ aparecimento da cor está condicionado à luz como objeto físico e estímulo, e ao olho humano como aparelho decifrador, tal como a existência dos personagens e imagens que Amado pintou com palavras nesta ficção, está condicionada ao produto livro como objeto físico e ao olhar do observador-leitor, que corporifica os personagens mediante os traços e cores impressos nas embalagens-capas

A chegada do livro na civilização pode ser comparada à entrada da luz, pois a criação do que hoje chamamos livro tornou-se de grande importância para a formação intelectual dos povos. Através da história oral e do livro, a maioria dos povos vem passando os seus conhecimentos para os seus descendentes e vem-se fazendo conhecer por outras civilizações, por isso o livro tem sido um sinal do poder social e do saber intelectual, sendo considerado símbolo da sabedoria e da ciência no universo, por isso é comum se ouvir dizer que o universo é um imenso livro.

Na história do livro, vários deles obtiveram lugares de destaque para a humanidade e contribuíram, dessa forma, para este olhar especial: os livros silibinos, que eram consultados pelos romanos para encontrar respostas divinas para suas angústias; o livro dos mortos, uma coletânea de fórmulas sagradas, que era enterrado com os mortos na sua tumba, a fim de que acompanhasse e ajudasse o falecido na sua travessia dos infernos até a chegada à luz eterna e o liber mundi, que era considerado a mensagem divina para seguidores do esoterismo islâmico.

O islamismo é considerado a religião do livro devido ao valor dado ao Corão. Na China, o livro é considerado atributo dos sábios. Para os adeptos do catolicismo, a Bíblia é considerada o livro dos livros, pois divulga a palavra de Deus. O cristianismo deu "a máxima consagração" ao livro. Era a religião do livro santo. Cristo é o único Deus que a arte antiga representava com um livro" (CURTIUS, 1979, p. 322). Na sua origem, o cristianismo produziu escrituras sagradas, documentos de fé. $O$ livro, portanto, traz consigo um valor que não é somente material.

A crença no valor simbólico do livro, por seus valores intelectuais, dificulta a visão deste como objeto comercial, isto é, como objeto de consumo corrente, puramente utilitário, perecível e dotado de valor mercantil. Vários conceitos 
foram associados ao livro durante a sua existência, a ponto de, para muitos leitores, o livro fechado significar a matéria virgem, a qual conserva o seu segredo, e o livro aberto, a matéria fecundada, pois o conteúdo já está tomado por quem o lê. Para outros, o livro era comparado a um coração, considerando que, aberto, oferecia seus pensamentos e sentimentos ao leitor, enquanto, fechado, os esconderia.

A responsabilidade da confecção de um livro, muitas vezes, é esquecida diante da simbologia de que o livro é um meio de difusão do saber de alguém, sua palavra, seus conhecimentos. O livro sintetiza o espírito de uma época, e sua realização gráfica nasceu da notável união da arte e da técnica, pois é obra conjunta de escritores, artistas e tipógrafos.

Pode-se definir o livro como um conjunto de diversas folhas de papel, pergaminho ou outro material, impressas ou manuscritas, reunidas e presas de modo a formar um volume destinado à divulgação. Sabe-se que o termo livro deriva do latim liber, que significa casca de árvore, e o termo biblos, de origem grega, tem o mesmo significado. Encontram-se registros de que a história do livro tem mais de cinco mil anos, apesar de grande parte dos autores, que o investigaram, afirmar a dificuldade de precisão quanto ao início da sua confecção'.

Outras civilizações se destacaram com publicações impressas em pequenas tábuas de argila no período VII a.C., mas o papiro foi o suporte que teve maior difusão, levando muito tempo para ser substituído pelo pergaminho, extraído da pele de animais, especialmente do carneiro, e confeccionado pelos habitantes de Pérgamo, que o denominaram, inicialmente, de membrana pergamena. O pergaminho foi sempre um material de preço elevado, o que provocou, segundo alguns autores, sua reutilização, resultando no fenômeno dos palimpsestos, com escritos anteriores que eram raspados e reescritos. Inicialmente, eles eram escritos apenas de um só lado, como os papiros, que foram chamados de volumen, até que descobriram a possibilidade de escrever dos dois lados, passando, então, a serem denominados de codex. Começam, então, a ter características semelhantes ao livro de hoje, pois esses manuscritos eram reunidos pelo dorso e recobertos com uma capa semelhante às encadernações modernas. Apesar desse aspecto, que até hoje é conservado, a noção de página somente aparece no fim da Idade Média, pois, anteriormente, mesmo sendo escrita dos dois lados, apenas possuía numeração em cada folha, originando as denominações retro e verso.

O livro em forma de codex viveu por mais de dez séculos e tornou-se característico da civilização cristã.

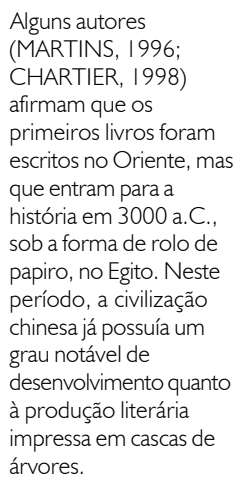
papiro, no Egito. Neste período, a civilização chinesa já possuía um grau notável de desenvolvimento quanto à produção literária impressa em cascas de árvores. 
2 Letra capitular primeira letra de um capítulo, normalmente impressa maior e mais decorada que as emais para chamar a atenção do leitor ou adornar a página (MARTINS, 1996).

${ }^{3}$ Vinheta - pequena ilustração que decora as páginas de um livro, revista ou jornal (RIBEIRO, I 987).

${ }^{4}$ Crisógrafos - artistas que trabalhavam com a utilização do ouro e prata na arte da ilustração, provavelmente por influência bizantina (MARTINS, 1996).
As ilustrações praticadas nos manuscritos medievais eram as miniaturas, pequenos ornamentos, letras capitulares ${ }^{2}$, fantasias, que funcionavam como decoração no impresso, e as iluminuras, desenhos ilustrativos do texto verbal impresso no livro. Encontram-se relatos de que a ilustração dos livros tem a sua origem na civilização romana, pois havia em Roma o hábito de ilustrar a história do texto com a representação gráfica dos episódios, ou então alegrá-lo com desenhos coloridos, que não tinham nenhuma relação com o texto verbal impresso. A diferença entre esses dois tipos de ilustração, para alguns autores, era apenas 0 número de cores empregado já que, na iluminura, a quantidade de cores era maior que na miniatura. Outros autores chegam a afirmar que a miniatura pode ser considerada a espécie e a iluminura, o gênero.

Existem registros que demonstram que a arte da ilustração dos livros se iniciou com os romanos, por volta do século III, mas algumas narrativas assinalam que os papiros e pergaminhos gregos já vinham enriquecidos com vinhetas ${ }^{3}$ e desenhos no próprio texto, muito antes dos romanos.

Diz-se que ilustrar é esclarecer, comentar, elucidar ou servir como exemplo ou modelo. Normalmente uma ilustração, como ato e efeito de ilustrar, adorna um texto verbal com imagens que o representam através das várias técnicas artísticas - desenho, pintura, fotografia e gravura. Immanuel Kant, grande influenciador do movimento filosófico lluminismo ou llustração, século XVIII, que tinha como objetivo a liberdade de pensamento para que reinasse a luz, afirmava que ilustrar é ter a coragem de se servir do seu próprio entendimento.

Ao mesmo tempo, as artes e as letras, desde a segunda fase da Idade Média, começaram a se deslocar dos conventos para os castelos e, com isso, os artistas passaram a representar, em suas ilustrações, os personagens com os traços e roupas dos seus contemporâneos, dando-lhes pormenores típicos, ou seja, uma "cor local". A partir desse momento, as representações passaram a ser chamadas de realistas e não simbolistas, daí a chamada fase "naturalista", que alcançou seu apogeu no século XV. As cores nas ilustrações vão sofrer influências orientais e, além do vermelho originário e do azul-claro comuns, os artistas passam a empregar nas suas iluminuras o dourado e o prateado, sendo denominados de crisógrafos ${ }^{4}$ os artistas que trabalhavam com caracteres em ouro e prata. Com isso, as ilustrações deixaram de ser binárias, impressas em apenas duas cores, ou ternárias, impressas em três cores, transformando-se numa verdadeira pintura que, com o passar do tempo, deu lugar à pintura moderna. 
Com essa transformação, os pigmentos que foram usados nessas iluminuras foram o preto, o branco, o vermelho, o azul, o verde, o glauco (amarelo) e o rosa (retirado do pau-brasil), e as ilustrações se tornaram uma "luz" colorida que invadia as páginas desses volumes, contribuindo para transformá-los em objetos de uma cultura própria, evidenciando, através das imagens impressas, o jogo das relações sociais e do poder.

Por muito tempo, o livro, produzido em abadias, castelos e conventos, era um objeto precioso, de grande formato, bastante ilustrado, mas pouco manejável. Com o advento das universidades, o livro passa a destinar-se à difusão e à circulação do saber. Consequentemente, surgem as oficinas livreiras dirigidas por leigos que, assim como os copistas, ofereciam seus serviços a particulares.

Com o passar do tempo, o alto custo do pergaminho foi superado por outro material descoberto pelos chineses e introduzido na Europa pelos árabes o papel, palavra que, etimologicamente, se originou do papiro. Desde a descoberta da técnica de fabricação do papel, marcada pelo ano de 75I, no Oriente, até quando alguns prisioneiros chineses foram obrigados a ensiná-la aos habitantes da Ásia Central, passaram-se, em média, seis séculos e meio. O grande desenvolvimento do papel está atrelado ao livro e à palavra escrita, pois, com esta união, a história da civilização ocidental passou a ser escrita no papel. Mas o papel somente passou a ser divulgado e vulgarizado a partir do século XVIII e início do século XIX, respondendo à necessidade de um material barato e considerado, na época, inesgotável, capaz de substituir com infinitas vantagens o pergaminho. Até o século XVIII, a fabricação do papel era manual, e a primeira máquina surgiu em 1798 e, coincidentemente, essas máquinas apareceram num período histórico de substituição da monarquia absolutista por regimes mais democráticos.

É importante observar a contribuição do papel, juntamente com a imprensa e, finalmente, do livro, para a Renascença e todo o desenvolvimento democrático da cultura ocidental. Com a facilidade de acesso a esses processos editoriais que proporcionaram a divulgação do pensamento, a cultura ocidental expandiu, para muitos países, principalmente os colonizados, os seus padrões estéticos e o seu modo de ver através das artes e, especialmente, através da literatura. O livro passou a ser um dos maiores meios de divulgação, mostrando uma hierarquia estética como legítima e a preservação de um senso comum de valores. Era o olhar de quem tinha possibilidade de fazer o livro sendo mostrado para outras civilizações, e, pelo valor dado ao livro, este olhar passava, na maioria das vezes, a ser visto como documento e verdade por quem lia. 
Dessa e de outras formas, o Ocidente continuou passando para outras culturas um corpo sistemático de representações e de normas, "ensinando" a outras civilizações a conhecer e agir, anulando a diferença do pensar e engendrando uma lógica de identificação que foi unificando o pensamento.

A conseqüência de ter em mãos a possibilidade de construção do livro e a divulgação desse produto favoreceram para que o discurso construído nos países ocidentais se tornasse, para os países não-ocidentais, semelhante ao que poderíamos chamar de "Discurso Competente" que, segundo Chauí (1989), é um discurso que se torna instituído, "que pode ser proferido, ouvido e aceito como verdadeiro e autorizado" porque foi emitido por quem tem conhecimento, por "supostos" especialistas que assumiram a posição superior de transmissão do conhecimento para outras culturas, com o respaldo do poder editorial.

Muitos desses discursos que, na sua maioria, eram baseados na realidade ocidental, passam a ser aceitos como verdadeiros por aqueles que compravam e liam os livros, mesmo que vivessem em culturas completamente diferentes. Este processo provocou uma obscuridade entre saber e poder, de forma que a competência instituída pelo saber de quem publicava o livro passou a ser uma arma para a dominação. Por meio do discurso publicado, era ensinado a cada leitor como se deveria relacionar com o mundo e com os demais seres humanos, instituindo modelos e provocando no leitor, muitas vezes, a ilusão de participação de um pseudo-saber. Este procedimento, ainda hoje, é muito discutido, já que alguns autores consideram que larga faixa do mundo não-europeu ou não-ocidental continua sofrendo grande influência da metodologia de pensamento da Europa. É evidente que outros fatores contribuíram para o domínio do pensamento europeu, mas não se pode deixar de mostrar a importante contribuição do livro.

Com o passar do tempo, as máquinas foram-se aperfeiçoando e a produção do papel bem como do livro, tornou-se cada vez maior. Este progresso técnico se acentuou, a partir do século XIX, ajudando a transformar o papel e, de forma consequente, o livro, em elementos de crescente difusão com imensa variedade e baixo custo, resultando, hoje, numa grande popularidade e com numerosos requintes de fabricação.

Por outro lado, alguns autores afirmam que os orientais também foram pioneiros na arte de imprimir, pois utilizavam, desde o segundo século da nossa era, algumas técnicas de impressão na pele humana, nos tecidos, na madeira e nos metais, construindo uma outra história, mas foi na Europa que estes processos de 
gravação se destacaram como uma projeção do manuscrito. Esta modificação na técnica de impressão do livro provocou reações, já que passou a ser "sobrenatural", pois era a arte de escrever sem a mão ou a pena, chegando ao ponto de vários colecionadores de manuscritos, na Europa, rejeitarem este novo processo de impressão e não aceitarem nenhum livro impresso.

O impresso, no Ocidente, aparece com as primeiras impressões xilográficas, técnica elaborada com o uso de madeira cavada num processo relevográfico, e nas quais as matrizes eram entintadas no alto relevo para, através de pressão, reproduzir a imagem no suporte. A xilografia imprimia em folha única como nos manuscritos, e, inicialmente, receberam o nome de tabelares ou tabulares porque eram feitas de tabuinhas. Os primeiros exemplares dessas impressões datam do século $X V$ e, na maioria, são reproduções de imagens de santos, baralhos e calendários. Ao lado dessas xilogravuras, aparecem outras técnicas e, posteriormente, destaca-se a gravura em metal, feita por meio de um processo calcográfico, ou seja, as matrizes recebiam as tintas nos sulcos do baixo relevo para, através da pressão, reproduzir a imagem no papel. Essas técnicas de gravação evoluíram chegando aos tipos móveis, que vieram a ser o primeiro passo para a chamada imprensa. Nesta nova arte, cuja criação foi atribuída a Gutenberg, as letras (ou tipo gráfico) eram construídas em metal separadamente, para, através da sua junção em palavras e frases, formar a matriz do texto. Difundiu-se rapidamente no transcurso do século $\mathrm{XV}$, chegando a mais de cem as cidades européias que instalaram oficinas tipográficas.

Os livros desse período tinham aspecto semelhante aos códices e eram chamados de incunábulos porque eram produto de uma arte incuna (no início), estendendo-se, mais ou menos, até o ano de I550. A partir, então, do surgimento da imprensa, as ilustrações manuais praticamente desapareceram, dando lugar, então, a ilustrações feitas mecanicamente.

A partir de I550, a impressão tipográfica expandiu-se e aperfeiçoou os tipos de caracteres usados. Em conseqüência, os livros, com o passar do tempo, perderam as características dos códices e assumiram uma fisionomia própria, com partes mais definidas como frontispício, numeração de páginas e o freqüente uso de ilustrações. A impressão de ornamentos e textos enfeitados acentuou-se durante o Barroco ${ }^{5}$, mas com a reação ao movimento, no fim do século XVIII, voltou a ser mais leve e harmônica. Nesse período, os progressos técnicos modificaram tanto os métodos de produção de textos impressos quanto o hábito de
Barroco - movimento artístico e literário nascido na Itália, vinculado à Contrareforma, que se espalhou por grande parte da Europa e América Latina. Caracterizava-se pelo uso excessivo de ornamentos muito rebuscados (MARTINS, 1996) 
${ }^{6}$ Tipografia - processo de composição e impressão baseado em tipos móveis, gravuras e clichês em altorelevo (RIBEIRO, 1987).

7 Planográfico processo de impressão caracterizado pelo uso de matriz plana, ou seja, sem calco ou relevo, passando a impressão por processos químicos (RIBEIRO, 1987). editores e leitores. Até 1800, falava-se apenas em tipografia ${ }^{6}$ para impressão gráfica, porém, mais ou menos nesse período, surge a litografia, ou seja, a impressão com matriz em pedra, de processo planográfico ${ }^{7}$, através de aderência e rejeição química, que deu origem à impressão off-set. É impossível deixar de registrar, também, a contribuição da invenção da fotografia em 1817, que favoreceu o aperfeiçoamento e a multiplicação das impressões em cores e tiragens sucessivas, além de outras máquinas com processos modernos oriundos da junção do aperfeiçoamento dos vários processos já descobertos ou inventados.

No século XIX, acelera-se a velocidade de composição do texto gráfico com a criação de máquinas mais potentes. Máquinas continuaram sendo inventadas no decorrer do século $X X$ até hoje, e o crescimento da indústria gráfica tornou-se revolucionário com o aparecimento da computação e de equipamentos que não mais utilizam chapa para imprimir, transformando radicalmente o processo de composição e impressão gráfica.

resultado de toda essa evolução gerou tiragens dos exemplares dos livros cada vez maiores, com qualidade sempre superior, conquistando camadas também cada vez maiores de leitores. A produção sempre crescente de livros de bolso e de coleções, que começaram a surgir por volta de 1930, e a venda de livros em bancas de jornal, em alguns países, foram de grande contribuição para a disseminação e vulgarização do produto livro, dado seu baixo custo.

que se percebe é a importância da criação e evolução do papel e da impressão gráfica para a história do livro, mas hoje um tipo diferente de livro já é uma realidade, o livro eletrônico, que aparece como conseqüência do aperfeiçoamento dos computadores, que permitem ao leitor o armazenamento de, em média, quatorze mil obras, em um pequeno aparelho com formato de um livro de pequeno porte, o que evita a conseqüente destruição da natureza para a fabricação da celulose, a matéria-prima usada na produção do papel industrial. Este novo livro vem facilitando, também, a aquisição de conhecimentos sem passar por alguns dos problemas até hoje não solucionados pela indústria do livro impresso graficamente. É importante salientar que o livro eletrônico ainda atinge pouquíssimas pessoas devido ao seu alto custo.

Enquanto a produção material do livro impresso vem crescendo, ultrapassando a maioria dos possíveis obstáculos, ao lado deste livro material, como citamos anteriormente, percebe-se um livro "espiritual", que possui uma carga aurática de luz devido a sua função de difusor do conhecimento humano. O livro "espiritual" 
é a aura que o livro adquiriu como objeto raro, visto que, desde a Idade Média, um escritor era apenas o que escrevia uma palavra inspirada por Deus, uma palavra que dizia de uma tradição, de alguma coisa que já estava ali, o escritor apenas a relatava e comentava. $\bigcirc$ livro era um objeto que poucos tinham possibilidade de compra, inclusive pelo requinte com que eram fabricados, com capas luxuosas, até de filigrana em ouro e incrustadas com pedras preciosas. Era um privilégio de poucos leitores e colecionadores a obtenção de um livro, por isso marcavam com o ex-libris, ou seja, com um brasão ou marca, que demonstrava de quem era a posse daquele exemplar.

Por outro lado, a concepção de que, entre alguém que escreve e alguém que lê, existe um livro, reforçou o seu papel como grande responsável pela comunicação e deu-lhe personalidade, levando-o a ser testemunho do espírito do homem que escrevia.

Apesar de ser considerado um objeto precioso, essa luminosidade do livro, que o caracteriza como meio de divulgação do saber do homem, possibilitandoIhe ver e conhecer o mundo, vem encontrando um grande obstáculo, gerando uma sombra na história da humanidade.

\section{a Sombra e a Interdição}

A luz quando encontra um obstáculo faz surgir a sombra. A interceptação da luz por um corpo opaco dá origem a um perfil escuro que chamamos de sombra. A sombra faz parte da percepção visual do homem, pois é através do jogo de luz e sombra que se obtem o contraste que faz parecer mais intensa a luz e que é de suma importância para a percepção das cores. Assim como a luz ao encontrar um obstáculo provoca a sombra, o livro, como iluminação para o conhecimento do homem, tem encontrado, na sua trajetória, um grande obstáculo, a censura, que tem provocado a sombra da interdição na história do conhecimento humano.

Toda cultura escrita esteve sempre ligada às repressões e aos gestos violentos. A participação das autoridades religiosas e políticas na história do livro provocou interdições de textos tidos como subversivos, o que gerou a destruição de milhares de exemplares e a condenação de autores, editores e, ainda, de leitores. Na história do livro, ao lado das relevantes contribuições para a publicação de 
grandes obras, há perseguições e até a fogueira, encarregada de proteger e "preservar" o patrimônio textual e os interesses do poder opressor. A criação de listas de livros desaconselháveis e proibidos pelas religiões, ideologias políticas e correntes de pensamento instituiu códigos de censura, como forma de organização. Esta atitude de destruição fez parte, seguidas vezes, da história do livro, objetivando erradicar as idéias de muitos autores. Esta sombria vontade de limitação de consumo de alguns livros foi de encontro à liberdade de interpretação dos leitores e ao direito do autor sobre a sua obra, tornando-se um castigo.

Um pensamento errôneo é admitir-se que a censura não existia em países liberais e democráticos como acontecia nos países de regime autoritário. Os acontecimentos ao longo da história provam o contrário. Em países considerados democráticos, há categorias de livros que não podem ser expostos nas vitrines, por serem classificados como pornográficos ou contra a segurança nacional. Sob a aparente idéia de proteção, o poder nestes países procura manter um discurso hegemônico. Como conseqüência dessa atitude, várias traduções, como também vários livros, sofreram modificações radicais, foram interditados e expurgados das prateleiras, o que continua até hoje, numa postura contrária à liberdade de expressão, que é direito de todo cidadão. A censura, nas artes em geral e, principalmente, na obra literária, através do tempo, vem atingindo requintes a ponto de serem selecionadas leituras para cada faixa etária, ou diferenciar o talento dos literatos como superiores e o de jornalistas como de segunda categoria, além de outras interdições de requintadas sutilezas. A obscenidade, a impiedade e a subversão são alvos preferidos dos códigos na censura à arte, até hoje. Além disso, a condenação, a crítica, a repreensão, as advertências, ou, ainda, os desejos inconscientes, os preconceitos, as omissões e outras manifestações do ser humano estão sempre sendo usados como ato ou efeito de censurar.

Apesar de toda esta sombra na luminosidade que o livro traz para a humanidade, a representação do livro como suporte da cultura e a sua história têm-lhe dado uma carga aurática superior e inestimável, fazendo com que o leitor esqueça de toda uma estratégia usada por alguns editores, na elaboração do livro no circuito comercial, para considerá-lo um produto de composição material como qualquer outro. Devido a essa aura adquirida, durante toda sua história, o objeto livro ainda continua sendo a "luz" para alguns homens, uma vez que é através dele que grande parte da aprendizagem se efetua. 


\section{a Refiração e $a$ Composição}

Um raio de luz solar separado através de um prisma triangular faz emergir, através de diferentes comprimentos de ondas, diferentes matizes de cores. Assim o comprovou Isaac Newton, quando descobriu que a luz podia ser refratada e que a sensação da cor branca era criada pelo impacto simultâneo de todos esses comprimentos de onda sobre os olhos do ser humano.

Coincidentemente, alguns homens veem a luz e não percebem como este fenômeno acontece, assim como eles veem o objeto livro e consideram que este ilumina a sua mente, através da absorção do conhecimento, sem perceber ou imaginar como é composto, quando o encontram pronto numa biblioteca ou livraria.

Assim como é importante conhecer a descoberta de Newton, para que a percepção da luz seja desmistificada e compreendida, é necessário observar como é construído o livro, separando-o por partes, para que se possa visualizá-lo como produto. Percebe-se, então, que a parte intelectual e a parte material formam a "luz"-livro, da mesma forma que os matizes de cores, numa síntese aditiva, formam a luz branca.

formato dos livros, ainda hoje, em sua maioria, é retangular, mas a evolução tecnológica das impressões e encadernações dos livros permite a sua construção com diferentes formatos, haja vista os livros infantis com formatos fantasias, confeccionados para atrair o leitor de menor idade. $\bigcirc$ recomendável é que o formato escolhido não seja incômodo para o leitor, isto é, deverá facilitar a forma de ele segurar o livro no momento da leitura.

Tecnicamente, o objeto livro compõe-se de duas partes - a material e a textual. A parte textual, ou intelectual, é o conteúdo significativo, e a material, é a parte física do livro, que se compõe de duas partes: a capa e o miolo. A capa, cobertura do miolo ou embalagem do livro, normalmente é constituída por uma folha de papel de gramatura ou peso maior, isto é, um papel mais grosso que envolve exteriormente o livro, para proteger e facilitar o seu armazenamento e transporte. A capa é o único espaço publicitário do livro e as editoras a usam para atrair os leitores nas estantes das livrarias ${ }^{8}$. Comunica a existência da obra literária que embala. Como o que vem impresso na capa se trata de rotulagem, normalmente informa o leitor sobre a obra literária que envolve, ostenta o nome da obra, do autor, e, quase sempre, vem acompanhada de alguma ilustração. 
A palavra diagramar significa fazer o projeto da distribuição gráfica de materiais a serem impressos: textos, títulos, fotos, ilustrações, logomarcas, de acordo com determinados critérios jornalísticos e visuais, ou seja, é o planejamento do espaço, técnica e esteticamente, dentro do formato desejado de uma comunicação, para que a informação chegue ao públicoalvo com o objetivo desejado. Diagramar tem origem no vocábulo diagrama, que significa representação gráfica esquemática de uma seqüência de operações ou de estrutura de um sistema. Quem diagrama e/ou ilustra as capas de um livro deverá, então, ler e conhecer a obra literária a que se destina a capa para, a partir daí, elaborar uma representação gráfica esquemática, que informe e seduza o observador-leitor para a compra do livro.
Os rótulos normalmente são divididos em painéis de acordo com a posição que o produto deve ser apresentado ao público consumidor.Uma embalagem pode ter vários painéis, os quais tendem a variar em quantidade e posição, de acordo com o formato do contingente do produto. A capa, como embalagem, permite a elaboração de mais de três painéis, ou seja, o principal, que é o espaço visualizado inicialmente pelo observador que olha para o livro, o segundo, que fica no verso deste primeiro, e o terceiro no verso da última capa, que é o quarto painel. Esses painéis são determinados pelo ritmo de visualização e manuseio do livro e a depender do volume e da encadernação ainda tem a parte que cobre o dorso do livro.

A criação da capa é feita, normalmente, por um funcionário da editora, que pode ser programador visual, diagramador, publicitário ou capista, como comumente é chamado, ou por algum profissional desse ramo indicado pelo autor da obra literária ou pela própria editora. O capista é um designer gráfico, mas o seu trabalho não é sistemático, é mais cultural que técnico, pois, na criação, deverá traduzir visualmente, com outros signos, a obra literária.

A diagramação faz parte da criação, constituindo-se na distribuição dos elementos que deverão ser expostos na capa, na escolha das ilustrações e textos críticos a serem colocados. Comumente, o projeto gráfico de uma capa atesta o valor da editora. Praticamente não há regras que comandem a disposição dos elementos, mas, normalmente, se exige do profissional que a faz um apurado gosto e bastante conhecimento técnico. Todos os elementos que vão ser colocados na capa devem ser tratados com a mesma importância, não só a ilustração em particular, como a escolha das fontes, cores e logomarcas. Cada elemento tem linguagem própria, inclusive as letras, visto que cada tipo passa para o observador determinada sensação, isto é, de elegância, de tradicionalidade ou de modernidade, por isso deve ser escolhido de maneira que se harmonize com o objetivo ou sentido do trabalho literário. A capa considerada ideal somente deverá servir para um determinado livro.

Quando um capista inicia a criação, diagramação ou elaboração de uma capa, é comum utilizar e incluir trabalhos de outros profissionais tais como fotografias, ilustrações, citações e outros discursos que legitimem o sentido que o capista quer demonstrar. O já conhecido é que ajuda o capista na interpretação gráfica. Por isso, é necessário que ele tenha um vasto conhecimento, pois cada livro aborda um assunto diferente, e este conhecimento é que o ajudará a estabelecer analogias.

A diagramação passou, com o tempo, do campo artesanal para o da especialização. $O$ capista deve desenvolver o seu discurso levando em conta contraste 
estético, forma, aproveitamento do texto, destaque, proporção, harmonia, impacto da comunicação sobre o observador e, acima de tudo, o ritmo com que a informação deve ser absorvida pelo público consumidor. É preciso que o capista pense no resultado final da capa no início do seu trabalho, visando à escolha dos materiais e à relação custo/benefício, principalmente fugindo do padrão, sem encarecer o projeto. A criação de um livro gráfico, normalmente, acompanha o estilo da época da sua produção e o assunto tratado no texto literário, sem ser repetitivo.

A diagramação pode ser simples, desejando apenas informar com ordenação e clareza, caracterizando-se pela discrição, como também se pode caracterizar por uma ornamentação, na qual os recursos utilizados, cores, tipos de letra, formato, ornamentos, linhas dominantes, cortes das fotografias, retículas, usados com fins estéticos, caracterizem-se por um design atraente e sedutor. A diagramação é uma arte comunicativa decorrente da condição de que a arte também é linguagem.

Quanto ao miolo, conjunto de folhas após a capa, pode estar em harmonia com a essência da obra literária ou não. Essas partes do livro se modificam de acordo com a especificidade da edição, variando se é mais luxuosa ou mais popular. Na mais econômica, há a necessidade de redução da quantidade de partes, colocando-se apenas as essenciais, pois o custo de confecção acaba sendo revertido para o público consumidor Também pode haver modificação no custo em conseqüência da quantidade de cores utilizadas. Quanto mais variações de cores, mais aumenta o custo.

Nas impressões dos livros e das capas, as cores escolhidas pelo capista ou pelos ilustradores aparecerão, sempre, devido ao uso de determinados pigmentos, que vão variar de acordo com os recursos técnicos usados no trabalho.

\section{os Pigmentos e a Obra Literária}

Os pigmentos são a matéria-prima da cor usada em alguma impressão e podem ser orgânicos de origem animal, vegetal ou sintéticos, criados através de processo químico. Os primeiros pigmentos usados pelo homem para pintar ou imprimir imagens foram feitos de terra colorida e, posteriormente, de tinturas retiradas de animais e plantas. Para preparar a tinta, esses pigmentos eram moídos com um meio agente ${ }^{10}$ ou aglutinante para sua fixação na elaboração da mensagem impressa. A escolha do tipo do pigmento a ser usado em uma determinada
10 Meio agente - aglutinante como óleo, ovo, cera ou resina usados para juntar as partículas do pigmento e aderi-los à superfície que está sendo pintada. 
impressão varia de acordo com a técnica empregada pintura, gravura, fotografia, desenho, off-set, rotogravura, serigrafia entre outros. Hoje, são muitas as técnicas usadas para imprimir uma mensagem. A existência dos pigmentos é que vai permitir a impressão do pensamento do homem no livro gráfico. Esses pigmentos são a matéria-prima para a confecção da obra literária e para a confecção das capas dos livros que, em sua maioria, são impregnadas de várias cores. Sem o pigmento, o homem dificilmente teria acesso ao código escrito e às imagens coloridas impressas. Neste trabalho por exemplo, torna-se essencial o conhecimento da matéria-prima que é o romance Gabriela, Cravo e Canela e de quem o escreveu, para a leitura desse texto.

Quando se fala em autoria, sinaliza-se para a pessoa que está na origem, que cria uma obra literária. É o autor que dá identidade e autoridade ao texto. A responsabilidade da autoria já foi muito discutida por toda a história do livro, chegando ao ponto de certos gêneros, para circularem, terem a necessidade da identificação da autoria. Esta identificação era obrigatória não somente para dar o mérito a quem elaborou a obra de arte, mas também para condenar aqueles que eram responsáveis pela ortodoxia política ou religiosa. Este fato chama a atenção para o risco de uma publicação, como também para a linha tênue entre o que pode ser o processo interpretativo e o esclarecimento de realidades difíceis de compreender. Demonstra a dificuldade que a sociedade ainda tem, de fazer a separação entre a censura e a liberdade de escrever.

A presença da autoria coloca em questão, ainda, a função do autor que, para publicar, utiliza-se de um patrocínio. Ao colaborar com a publicação, o patrocinador muitas vezes impõe o que deve ser escrito, chegando ao extremo de modificações nos textos de acordo com os seus interesses.

Também se discute a responsabilidade do autor quanto ao sentido e à significação do que narra, sua intenção, seu projeto original. $O$ sentido de um texto não poderá ser reduzido ao suposto sentido que tem para o autor e seus contemporâneos, pois deve ser incluída a possibilidade de modificações diante da faixa etária dos leitores, dos contextos socioculturais diversos, sem esquecer a situação de gênero.

Por outro lado, os autores e intelectuais sempre desempenharam uma função importante na hierarquia do poder, como organizadores sociais, formadores de opinião e profissionais, que buscam construir a "Nação". Neste aspecto, a literatura aparece como privilegiada, pois relata costumes culturais e variações linguísticas que contribuem para criar um sentimento de unidade. 
Assim, não se pode deixar de, mesmo em síntese, falar sobre o autor do referido texto literário em estudo, matéria-prima para a elaboração deste trabalho. Conhecer o autor é uma forma de aproximar as leituras produzidas de sua visão de mundo e do contexto político, social e cultural no momento da criação. É observar as condições de produção dos discursos. Foi muito difícil relatar, resumidamente, a vida de Amado diante de tantos feitos. Foram selecionados alguns fatos que demonstram não só o reconhecimento da sociedade, mas também a interdição do seu trabalho intelectual.

Jorge Amado nasceu na Bahia, em Ferradas, município de Itabuna, considerada a terra do cacau pelo grande cultivo deste fruto na região. Filho do Coronel João Amado de Faria e de D. Eulália Leal Amado, nasceu em 1912, numa fazenda do pai. Aprendeu a ler, inicialmente, com a sua mãe e, posteriormente, foi para llhéus onde passou a infância e cursou as primeiras letras, trabalhou com seu pai e, depois de algum tempo, foi para Salvador continuar seus estudos no Colégio Antônio Vieira e no Ginásio Ipiranga. Em Salvador, passou a trabalhar nos mais diversos jornais.

Segundo alguns autores, ele se juntou a alguns boêmios, jovens literatos de certa Academia a que chamavam de Academia dos Rebeldes ${ }^{\prime \prime}$. Com 17 anos, passou a freqüentar os terreiros da Bahia, onde foi bem recebido, participando dos rituais do Candomblé com muito respeito. A sua experiência nas lavouras do cacau e a consciência das dificuldades vividas pelos trabalhadores tornaram-no anti-racista. Como jornalista, viveu defendendo pais-de-santo que comumente eram presos por praticarem suas crenças. Posteriormente, instalou-se na Capital Federal, que, na época, era o Rio de Janeiro, para estudar Direito, e prosseguiu escrevendo. No Rio de Janeiro, conviveu com vários intelectuais ${ }^{12}$. Aproximouse do editor Augusto F. Schmidt, publicando, em I93I, seu primeiro romance, O país do Carnaval, sucesso editorial que recebeu apoio da crítica e aceitação do público. Ainda nesse ano, são publicados os contos "Sentimentalismo" e "O homem da mulher e a mulher do homem" no Jornal O Momento, em Salvador.

Na Faculdade Nacional de Direito formou-se Bacharel em Ciências Jurídicas e Sociais em 1935, não tendo jamais exercido a profissão. Com 19 anos, já era um escritor respeitado pelos regionalistas, pois sua literatura revelava os problemas sociais do Brasil, sua diversidade regional e as características das religiões e cultos de origem africana praticados pelo povo baiano. Nesta época, Jorge Amado se envolve com o Partido Comunista e, em 1933, publica a obra Cacau, que obteve destaque bem maior que o romance anterior. Amado narra as dificuldades vividas por quem trabalhava nas fazendas de cacau, sendo seu primeiro romance
"I João Cordeiro, Dias da Costa, Alves Ribeiro, Edson Carneiro, Sosígenes Costa, Walter da Silveira, Couto Ferraz e Clóvis Amorim. Com dois desses companheiros, Dias da Costa e Edson Carneiro, publicou a novela Lenita.

${ }^{12}$ Vinícius de Morais, Jorge de Lima, Aurélio Buarque de Holanda, Santiago Lima, o seu primo Gilson Amado e outros. 
${ }^{13}$ Nesse mesmo ano, Getúlio Vargas, líder político, deu um golpe e implantou, no Brasil, a ditadura do Estado Novo. Desta vez, Amado perdeu mais de dois mil exemplares dos seus livros queimados numa praça de Salvador pelo Exército, por serem considerados obras subversivas.

${ }^{14}$ Nessa época, lança um pequeno livro de poemas, A estrada do mar, o qual editou por conta própria e distribuiu para amigos, apesar da censura persistente aos seus trabalhos literários. traduzido para uma língua estrangeira. Censurado por questões políticas, o livro foi apreendido pela polícia, mas pouco tempo depois foi liberado.

Tornou-se tradutor de importantes autores da América Latina e publicou outro romance, Suor, que, segundo o escritor, completa a trilogia de aprendiz. Logo em seguida, lança Jubiabá, um romance que enfoca os problemas raciais e preconceitos contra as crenças populares e apresenta o primeiro herói negro do romance brasileiro, líder grevista em Salvador. Em 1936, publicou Mar morto. Em razão de um levante comunista, chamado Intentona, foi preso por seu ideário político e social.

Depois de libertado, Amado viajou pela América Latina, foi aos Estados Unidos e iniciou novas amizades com muitos escritores, entre eles Pablo Neruda, companheiro de Partido. Continuou a sua viagem pelo Brasil, logo publicando seu sexto romance, Capitães de areia, aventura em que o autor defende a vivacidade e a coragem dos meninos de rua abandonados, um problema social ainda hoje presente nas grandes cidades brasileiras. Em 1937, Amado foi novamente preso devido ao seu envolvimento com uma campanha para eleger José Américo de Almeida à Presidência da República' ${ }^{13}$.

Em 1938, vários dos seus romances já estavam sendo traduzidos e editados em diversos países da América, Europa e Ásia. No Brasil, Amado ocupou-se com atividades políticas, combatendo a ditadura, denunciando o fascismo e defendendo a anistia para alguns presos, e passou a trabalhar em diversos jornais do Rio de Janeiro e São Paulo' ${ }^{14}$.

Em 1939, compôs com dois amigos de partido político, Dorival Caymmi e Carlos Lacerda, a serenata Beijos da Noite, e, em 1941, publicou a biografia $O$ ABC de Castro Alves. Já em 1942, Amado, em parceria com Graciliano Ramos, José Lins do Rego, Rachel de Queiroz e Aníbal Machado, publicou o romance Brandão entre o mar e o amor, quando ainda exilado na Argentina e Uruguai, iniciando depois, em Montevidéu e Buenos Aires, outra biografia, a de Luís Carlos Prestes, dirigente comunista que se encontrava prisioneiro do chamado Estado Novo. Este livro, cujo título é Cavaleiro da Esperança, foi publicado em 1942 no Brasil, mas foi vendido na maioria das cidades brasileiras por contrabando, servindo como campanha de anistia para a libertação de Prestes.

Depois desse exílio, Amado retornou ao Brasil e logo foi preso em Porto Alegre e confinado na Bahia. Depois de solto, ainda atuando na imprensa, escreveu Terras do Sem Fim, que publica em 1943 e, em 1944, São Jorge dos Ilhéus, período em que Amado se separou da primeira esposa. Em 1945, participou do Congresso de Escrito- 
res que aconteceu em São Paulo com merecido destaque, pois este evento foi um Encontro de relevância contra a política imposta pelo Estado Novo ${ }^{15}$.

Ainda em 1945, foi eleito deputado pelo Estado de São Paulo com grande votação, e, como parlamentar, defendeu e fez aprovar a liberdade de culto, impedindo, a partir daquele ano, que alguém fosse preso por ser aliado de algum culto afro no Brasil, além de criar uma lei para defender os direitos do escritor brasileiro.

Em 1946, foram publicados Seara Vermelha, romance, também dedicado ao líder político Carlos Prestes, e ainda o texto político Homens e coisas do Partido Comunista, considerado por alguns críticos como propaganda partidária.

Em 1948, o Partido Comunista tinha voltado à clandestinidade. Após sua expulsão do parlamento, Amado foi exilado para Paris, onde viveu com Zélia e o filho João Jorge até 1950. Na Europa, Amado conviveu com intelectuais renomados, que se tornaram seus amigos, como Jean Paul Sartre, Simone de Beauvoir, Pablo Picasso e Albert Camus, que davam ao seu trabalho o merecido reconhecimento. Durante esse período, Amado viajou por toda a Europa, conheceu Moscou e escreveu para o seu filho, durante a viagem, o livro infantil O Gato Malhado e a Andorinha Sinhá, que somente foi publicado em 1976'.

Em I95I, lança O Mundo da Paz, um livro também considerado como guia de viagens, com propaganda dos países que se diziam socialistas, obra que obteve bastante sucesso apesar de ter sido proibida no Brasil. Por causa deste livro, Amado foi novamente processado. Ainda em Dobris, escreve sobre a tragédia que foi o Estado Novo, a trilogia "Os ásperos tempos", "Agonia da noite" e "A luz do túnel", reunidos sob o título Subterrâneos da Liberdade, que é considerada um relato sobre a ditadura do presidente Getúlio Vargas no Brasil'17. Recebeu o Prêmio Stalin, de grande importância para os soviéticos, que, posteriormente, passou a chamar-se de Prêmio Internacional Lenin.

Voltou ao Brasil em 1952, depois de viagem pela China e Mongólia, e passou a residir no Rio de Janeiro. Trabalhou na Editora Vitória, ligada ao Partido Comunista, dirigiu a coleção Romances para o Povo, presidiu a Associação de Escritores Brasileiros e foi chefe da redação da revista Para Todos. Em 1956, abandonou o Partido Comunista, muito abalado com as denúncias que Krushev fez contra Stalin, em Moscou, no XX Congresso do Partido Soviético. Afirmou publicamente que deixou a militância partidária porque o impedia de ser um escritor pleno. A partir dessa data, seus romances se modificaram, passando a ter diferentes características, levando vários críticos a considerá-los como representantes de uma nova fase.
${ }^{15}$ Justamente quando Amado estava envolvido com todo esse movimento político de esquerda, conheceu Zélia Gattai, que passou a ser sua companheira em 1945, ano em que foi novamente preso e, depois de solto, publica um guia de viagens chamado Bahia de Todos os Santos: Guia de ruas e de mistérios, escrito em São Paulo, onde trabalhava para a imprensa e dirigia o jornal do Partido Comunista.

${ }^{16}$ Ainda exilado, Amado perdeu a sua filha mais velha, Eulália, e não pôde comparecer ao enterro. Em 1950, foi expulso também da França e foi residir em Dobris, na Rússia, num castelo onde funcionava a União dos Escritores da

Tchecoslováquia, até 1952.

17 Também em 1951, em Praga, nasceu sua filha Paloma Amado, também fruto do seu casamento com Zélia Gatai. 
${ }^{18}$ Xangô - um dos orixás das cerimônias religiosas afrobrasileiras,

relacionado aos elementos da natureza, raio e fogo.

${ }^{19}$ Ainda nesse ano, foi eleito para a cadeira de número 23 da Academia Brasileira de Letras.

${ }^{20} \mathrm{Em}$ 1971, recebeu o Prêmio da Latinidade na França.

${ }^{21}$ Em 1977, recebeu o título de Comendador da Ordem de Andrés Bello, na Venezuela e, em 1979, o título da Ordem das Artes e das Letras na França.
Em 1957, estabelece uma grande amizade com uma das maiores ialorixás da Bahia, mãe-de-santo do terreiro do Gantois, mais conhecida como Menininha do Gantois, e, pouco tempo depois, recebe uma das mais altas honrarias do Candomblé, passando a ser um ministro de Xangồ ${ }^{18}$. Depois que foi elevado a ministro (ogã) do Candomblé, Amado passou a ter obrigações para com a comunidade ligada a esse culto.

Em 1958, publica uma obra que é considerada pela crítica um dos seus mais importantes romances, por descrever o jeito de ser do brasileiro, como afirmam alguns autores. Intitulado Gabriela, Cravo e Canela, o livro enfoca temas variados como a opressão das mulheres, o coronelismo e alguns problemas sociais brasileiros.

A partir dessa publicação, Amado passa a dar mais atenção, em seus romances, aos anti-heróis - os chamados vagabundos, as prostitutas e os bêbados. Esta nova fase do trabalho amadiano revela a vida popular da Bahia, com o hibridismo racial do seu povo, seus cultos e religiões, sua culinária, considerada por muitos como exótica pelas misturas extravagantes, e, principalmente, o universo social e cultural baiano, extremamente complexo e variado. Dá visibilidade aos grupos socialmente desfavorecidos e excluídos, ao lado dos seus opressores, e destaca as injustiças sociais e a beleza do ser humano. Segundo alguns críticos, esta "nova" narrativa amadiana evidencia o caráter múltiplo do povo baiano e a diversidade de cores na sua formação.

Em 196I, publica duas novelas - A morte e a morte de Quincas Berro D'água, considerada por alguns críticos como exemplar em ousadia e humor, e Os velhos marinheiros $^{19}$. Em 1964, lança a primeira edição de Os pastores da noite, e, em 1965, é a vez do conto As mortes e o triunfo de Rosalinda. Já em 1966, publica um dos seus mais divulgados romances, Dona Flor e seus dois maridos.

Em 1969, lança Tenda dos Milagres, no qual aborda a miscigenação, usando uma forma de narrar considerada por alguns críticos como carnavalizada e inspirada na literatura de cordel $^{20}$. Em 1972, publica Tereza Batista cansada de guerra e, em 1977, Tieta do Agreste, outro romance, que tem como personagem principal uma mulher, retratando, como na maioria de seus personagens femininos, mulheres mal-amadas, oprimidas, valentes, moralistas, fogosas, mas sempre personagens femininos com características bem brasileiras ${ }^{21}$.

Em 1979, publica Farda fardão camisola de dormir: fábula para acender uma esperança, considerado pela crítica como um romance bem humorado, menos crítico. Em 1984, edita Tocaia Grande: a face obscura, um romance considerado por alguns críticos como audacioso. Ainda em 1984, publica a história para crian- 
ças A bola e o goleiro, e, em 1986, O capeta Carybé, uma homenagem ao amigo e artista plástico Carybé.

Em 1988, publica o romance $O$ sumiço da Santa: uma história de feitiçaria e, ainda, o conto História de Carnaval. Em 1989, publica o conto De como o mulato Porciúncula descarregou o seu defunto ${ }^{22}$. Em 1992, registrou, no seu livro de memórias Navegação de Cabotagem, uma homenagem à vida ${ }^{23}$. Edita, no mesmo ano, seu último romance A descoberta da América pelos turcos, uma homenagem aos brasileiros de fora, e posteriormente, em 1993, publica outro texto político Discursos ${ }^{24}$.

Apesar da idade avançada, Amado não parou de escrever e deixou dois livros inacabados Boris, o Vermelho e A apostasia universal de Água Brusca.

Faleceu em 6 de agosto de 200I, aos 88 anos, deixando uma quantidade imensa de publicações, um registro literário que retrata a miscigenação da Bahia, seus costumes, sua cultura, sua língua popular, e um vocabulário absolutamente baiano.

A obra Gabriela, Cravo e Canela escolhida como matéria-prima desse trabalho, como dito anteriormente, foi publicada 27 anos depois do lançamento do primeiro livro de sua autoria e marcou uma nova etapa na produção intelectual do autor, de acordo com a crítica. Esta nova narrativa amadiana é caracterizada como lúdica, humorística e sem maiores preocupações político-ideológicas.

O romance, cuja trama se desenvolve em 1925, tem como cenário a cidade de llhéus, no sul da Bahia, conhecida pela luta de posse de terras férteis para o cultivo do cacau. Amado focaliza, em seu texto, a cidade num momento de transformações políticas e econômicas, com o progresso se instalando e transformando a fisionomia da cidade. Neste ambiente é que o autor desenvolve o seu imaginário, narrando a história de vários personagens, entre eles, a da brasileira Gabriela e do árabe Nacib. Na narrativa, Amado descreve dois grupos políticos interessados em defender os interesses citadinos: os coronéis, que representam a oligarquia local, conservadora inclusive pelo exercício constante do poder, e o grupo de oposição, representado pela classe média em ascensão, interessada em instaurar, no local, uma nova ordem e, principalmente, o chamado progresso. Neste contexto é que Amado representa alguns dos seus personagens masculinos e femininos, inclusive a Gabriela, com seus valores, preconceitos, relações interpessoais com a família patriarcal brasileira, suas raízes, suas rígidas divisões de papéis, além da mistura saudável entre estrangeiros e brasileiros no cotidiano ilheense.
22 Também recebeu o Prêmio Dimitrov, em Sofia, o Prêmio Pablo Neruda, em Moscou, e o Prêmio Etrúria de Literatura, na Itália. Já em 1990, tornou-se também Doutor Honoris Causa em Língua e Literatura da Universidade de Dagli Studi, em Bari, Doutor Honoris Causa da Universidade de Israel e recebeu o Prêmio Cino del Duca e o Prêmio Mediterrâneo, ambos na Itália.

${ }^{23}$ Foi titulado como Comendador da Ordem do Mérito de São Jorge dos Ilhéus, na Bahia, e Comendador da Ordem de Maio, na Argentina.

${ }^{24}$ Continuou sendo homenageado recebendo os títulos de Doutor Honoris Causa das Universidades de Pádua, na Itália, em 1995, de Sorbonne, na França, de Lisboa, em Portugal, e de Bolonha, na Itália, em 1998. Em 1997, já havia também recebido os seguintes prêmios: Prêmio Vitaliano Brancatti, na Itália, Prêmio Luís de Camões, em Portugal, Prêmio Jabuti e Prêmio Ministério da Cultura, no Brasil. 
Os personagens femininos - esposas, filhas de coronéis, solteironas, empregadas domésticas e prostitutas - se destacam como elementos muito importantes no enredo, chegando a ponto de alguns capítulos serem intitulados com nomes de mulheres, tais como: $O$ langor de Ofenísia, A solidão de Glória, $O$ segredo de Malvina, O luar de Gabriela, nos quais o narrador descreve o universo feminino, procurando identificar os vários papéis atribuídos à mulher e os seus diferentes comportamentos na sociedade brasileira.

Sobre as mulheres, Amado, em entrevista a Raillard (1990), afirma que é verdade que as mulheres têm papel ativo nos seus livros. $\bigcirc$ que ele sempre dizia e repetia é que a mulher, no Brasil, é explorada como classe e também como sexo. Ela é duplamente oprimida: como o são todas as pessoas do povo brasileiro e, particularmente, porque é mulher. Foi por isso que ele quis que alguns dos seus personagens fossem mulheres, apresentando a luta do povo brasileiro, citando Gabriela como exemplo.

Nesse texto amadiano, o personagem Gabriela recebe duas referências - cravo e canela, duas especiarias trazidas pelos portugueses no período colonial para o Brasil e que são muito usadas como condimentos na culinária brasileira, fazendo alusão à cor e ao sabor desses temperos, deixando subentendida a relação da personagem mestiça, morena, com a cor marrom da canela e o cheiro e sabor do cravo e da canela. Esta referência já coloca o personagem feminino mestiço relacionado ao ato de comer, de degustar e saborear, como explica muito bem Sant'Anna, no seu livro $O$ canibalismo amoroso (1993): a mulher fruto, que relaciona erotismo e culinária, a mulher para ser comida, ligada à alimentação erótica e gastronômica, que confunde o comer literal e o metafórico, diferente da mulher de etnia branca sempre associada à mulher flor para ser sentido apenas o seu perfume.

A Gabriela surge na trama como retirante do sertão, região bastante seca, chegando a llhéus suja, empoeirada, vestida de trapos, na miséria, sendo contratada pelo árabe Nacib como empregada doméstica, passando não somente a cozinhar como também a satisfazê-lo sexualmente. A Gabriela revela-se como mulher ideal, segundo os anseios de Nacib, cozinheira e amante. De acordo com Amado, em entrevista a Raillard (1990, p. 277):

A Gabriela é quase um símbolo do povo na sua inocência, sua ignorância do comprometimento, fora de todas as regras, de todas as convenções inventadas pela sociedade. É alguém que modifica as regras do jogo, ou que ao menos ajuda a modificá-las, uma mulher simples e despojada, tão despojada quanto o povo. 
Em volta desses dois protagonistas, gira toda a trama, inclusive o assassinato da esposa de um dos coronéis por ter sido encontrada, pelo seu marido, na cama com o seu dentista, culminando com a primeira prisão de um coronel por assassinato da sua esposa.

Este romance amadiano tem tido grande sucesso de público em vários países, haja vista as várias edições, estando, atualmente, na $100^{a}$ edição no Brasil. É um dos trabalhos de Amado mais traduzidos, com registro de mais de trinta e cinco idiomas, inclusive a quantidade de edições foge ao controle da família do escritor baiano e da Fundação Casa de Jorge Amado, que preserva e estuda o trabalho do romancista. Além de tudo, tem tido também constantes adaptações para cinema e televisão, histórias em quadrinhos e fotonovelas. Sobre o controle das edições, Amado relata a Raillard (1990) que as editoras não avisavam nada ao autor, ele ficava sabendo dos lançamentos por acaso e a duras penas conseguia obter um exemplar do seu próprio livro. Este comentário foi feito quando ele relatou sobre uma edição cubana, a que só teve acesso porque a enviaram para que autografasse.

Assim, quando Amado escreveu Gabriela, cravo e canela, matéria-prima da construção das capas de cada edição publicada, já pressupunha que, a interação autor, texto e cada leitor diferente, propiciava inúmeros e distintos diálogos.

Perceber melhor a dialogicidade entre o discurso de Amado e o discurso das capas é identificar o que chamamos discurso e os signos escolhidos para sua representação. Tais signos podem ser comparados com os pigmentos ou tintas escolhidas para dar cor a uma determinada impressão, isto é, com a seleção de cores feita por um pintor para composição do seu discurso. Um escritor, um artista gráico ou um ilustrador escolhe os signos criteriosamente para dizer o que se passa em sua mente, para simbolizar a sua criação. Para isso, percorre uma infinidade de signos do seu conhecimento, tentando ajustá-los a uma possível interpretação, assim como o pintor coloca diversas cores de tinta na paleta para conseguir, através da mistura, a representação ou tonalidade ideal.

É fundamental observar como os capistas elaboraram os seus discursos, para analisar e compreender como escolheram os signos e pigmentos para representar o discurso amadiano, nas capas das diferentes edições brasileiras. Para tanto, são aqui utilizados alguns recursos da Teoria da Análise do Discurso e da Semiótica, com o objetivo de chegar a uma leitura, entre as múltiplas possíveis, das capas elaboradas para o público-alvo brasileiro. 


\section{as Tintas da Paleta e o Discurso das Capas}

"A linguagem em si mesma é uma complexa e maravilhosa mistura de padrões, o simbólico e o expressivo, nenhum dos quais poder-se-ia desenvolver até à sua atual perfeição sem a interferência do outro"

Edward Sapir 


\section{a Mistura e a Construção}

Os pigmentos é que dão origem às tintas. Antigamente, eram misturados às gorduras animais e aquecidos para serem trabalhados. Os primeiros pigmentos usados na pintura foram óxidos de ferro, carvão e osso queimado, hoje existe uma variedade de produtos químicos que são usados pelas indústrias de tintas para conseguirem uma gama de cores que cada vez chega mais perto das cores naturais. O pintor, quando vai pintar uma tela, escolhe cuidadosamente as tintas que utilizará no seu trabalho e coloca-as na paleta para que vá retirando, aos poucos, com o pincel ou espátula, no intuito de dar forma e expressão a seus pensamentos.

Para representar seu pensamento no discurso, seja verbal ou não-verbal, tanto o pintor, quanto o ilustrador ou o capista podem se utilizar não só das várias técnicas de representação da forma, como também dos pigmentos que a paleta de tintas oferece. Como a escolha não é aleatória, para a construção de uma capa, os profissionais precisam conhecer o sentido das formas e das cores que estão utilizando, considerando o contexto do público-alvo daquela comunicação. A cor é um signo como qualquer outro e, para ser usado, deve buscar o movimento de interação com o(s) sentido(s) que representa em cada contexto. $\mathrm{Na}$ construção de um discurso para uma capa de livro, a seleção dos signos, cores, imagens textos, títulos e logomarcas, será responsável pelo sucesso ou fracasso da comunicação.

O discurso elaborado para seduzir o público-alvo na compra de um livro é, antes de qualquer coisa, criar imagens com conteúdo significativo, a partir das idéias da obra literária que será colocada à venda. As capas são normalmente simbólicas e estabelecem uma relação com o imaginário do leitor que as apreende no seu todo, produzindo efeitos de sentidos, sem necessidade de traduzir a cadeia de imagens 
e textos em idéias e conceitos. O discurso publicitário das capas é construído, na maioria das vezes, com as linguagens verbais e não-verbais, num processo de diagramação. Nas capas, percebe-se a presença de uma ilustração e um texto com as informações básicas sobre a obra literária, que variam de acordo com o tipo de publicação, os interesses da editora e a cultura do público-alvo.

Como em outras linguagens, na linguagem artística, existe um sujeito-emissor e/ou locutor, fonte da comunicação de um discurso, que transmite a informação originada da fonte, exposta em um veículo - jornal, revista, livro, filme - e um receptor-observador-leitor-alocutário que reconhece e decifra os signos para chegar à compreensão. Segundo a teoria da análise do discurso, o sujeito-emissor tem três propriedades: uma atividade psicofisiológica necessária à produção do enunciado; ser o autor-origem dos atos de emissão, ou seja, ordem, pergunta e asserção; e um ser designado em um enunciado pelas marcas de primeira pessoa. Sendo assim, pode haver vários sujeitos em uma enunciação, assim como há uma necessidade de distinção entre sujeitos-personagens, enunciadores e locutores. A mistura das várias vozes no discurso das capas concretiza a heterogeneidade discursiva e a polifonia. Nas capas, são usadas diferentes estratégias discursivas, como o discurso direto, que conserva as marcas próprias e a identidade de quem diagrama e elabora a capa, e o discurso indireto no qual o autor utiliza a subordinação.

Os discursos dos capistas são compostos de pré-construídos num processo de reconfiguração incessante e, segundo Maingueneau (1998, p.86), “[...] o interdiscurso é um conjunto de discursos de um mesmo campo discursivo ou de campos distintos, de épocas diferentes", ou, ainda, "[...] um conjunto de relações entre diversos intradiscursos" (1984, p.30). Portanto, ao elaborar a capa, o capista intervem na sua construção como sujeito do discurso, integrando textos preexistentes ou pré-construídos (enunciados anteriores, já construídos e admitidos numa coletividade) que fazem parte do domínio de seu saber, que constituem recortes do interdiscurso. É transitando pelo discurso de Amado que o capista constitui o intradiscurso e trabalhando a tessitura, a construção linguística e artística através da diagramação, numa dimensão horizontal.

Nos discursos das capas, é possível observar informações implícitas que podem estar pressupostas e/ ou subentendidas. Os pressupostos são vistos como ideias expressas de forma não explícitas, mas apresentadas como se fossem aceitas por todos, enquanto os subentendidos, como insinuações não marcadas no discurso, tornando-se assim responsabilidade do observador-leitor. 
O discurso publicitário, na sua maioria, aproveita-se de pressupostos e subentendidos, abrindo espaço para várias interpretações, seja através da linguagem verbal ou não-verbal. A teoria da semiótica subliminar de Calasans (1989) comprova a hipótese de existirem traços subliminares visuais e gráficos em várias peças publicitárias projetadas pelo responsável na criação. O Silogismo Subliminar e a Lei da Totalidade da Gestalt provam que uma mensagem lacunosa, incompleta ou fragmentada, quer num texto escrito, quer em imagens de baixa definição, exige do observador que complete o vazio de sentido, passando nesse momento a ser cúmplice da construção de sentido da mensagem. Nas imagens publicitárias que possuem modelos parcialmente vestidas, os autores esperam que o observador complete a forma vista de acordo com o seu imaginário. Essas percepções e a materialidade linguística, como verbos factivos ou contrafactivos, marcadores aspectuais, interrogativas parciais e outros, influenciam e manipulam o observador-leitor, levando-o a utilizar uma informação recebida anteriormente, convertendo-a num pressuposto. Percebe-se, assim, que o discurso das capas, assim como qualquer discurso, é não apenas a linguagem em interação (emissor e receptor), como também a linguagem em relação às suas condições de produção. Quanto às condições de produção, segundo Sytia (1995, p.77), "[...] trata-se dos fatores pragmáticos do ato da produção discursiva, ou seja: situacionalidade, intencionalidade, aceitabilidade, intertextualidade e informatividade". As condições de produção são responsáveis pelas marcas formais deixadas pelo contexto histórico-social dos interlocutores no discurso da capa. O lugar de onde o locutor fala vai estar representado no que ele diz, seja ele autor literário ou capista, porque as condições de produção são representações dos lugares determinados na estrutura de uma formação social, que manifestam a subjetividade e as relações do indivíduo no grupo. São forças individuais e imaginárias que contam o lugar social e a posição dos interlocutores.

Essa dinâmica na constituição do discurso da capa vai fazer do emissor-autorcapista e do receptor-leitor, público-alvo, seres que agem como parte de uma engrenagem que pode transformá-los em sujeitos manipulados. Diante disto, o capista passa a ser essencialmente histórico, envolvido com o seu contexto, e, como a capa é produzida mediante um envolvimento com outros discursos historicamente já construídos, os interdiscursos, outras vozes irão aparecer.

O observador-leitor, aquele que lê e que vê os códigos presentes na capa, atribuindo sentido(s), através dos processos de comparação e avaliação, entre 
outros, é quem vai chegar às conclusões. A recepção da capa, portanto, pode ter pouco a ver com o resultado interpretativo do capista, pois os códigos usados na capa não têm sempre o sentido que o capista lhes quer dar, mas o(s) sentido(s) diante das condições de produção e de leitura do receptor. Percebe-se, então, que existe um diálogo permanente entre autor e cada leitor, pois a interpretação dependerá dos juízos de valor implicados. Segundo a teoria bakhtiniana, a linguagem é dialógica num duplo sentido: na interatividade entre o dito e o compreendido e, ainda, no sentido de que o discurso é constituído de outros discursos com os quais se relaciona. (BAKHTIN, 1884). $O$ discurso das capas, no corpus por exemplo, mantém uma relação interdiscursiva com o texto de Amado, a matériaprima com a qual o capista sempre dialoga. Sendo assim, o capista procura utilizar, em seu discurso, signos que aproximem a interpretação do observador-leitor ao objetivo desejado.

Pode-se também, ao observar uma capa, encontrar a intertextualidade, pontos de referência que se estabelecem entre o discurso e o contexto, interferências do conhecimento partilhado ou citações presentes no discurso. Algumas fotos, citações de autores renomados e ilustrações são intertextos usados pelos capistas. A formação discursiva, segundo Maingueneau (1998, p.68) "[...] é o lugar específico da constituição do sentido, é o que determina o que pode ser dito a partir de uma posição dada em uma conjuntura, mantendo uma coerência visível horizontal". A formação discursiva pode designar conjuntos de enunciados relacionados a um mesmo sistema, sistema de regras que funda uma unidade de enunciados sócio-historicamente circunscrita, certa conjuntura histórica, um espaço entre uma concepção constrativa e interdiscursiva ou, ainda, os posicionamentos ideológicos marcados.

Neste trabalho, adotou-se o conceito de formação discursiva para discursos ou parte destes que tenham posicionamentos ideológicos marcados. Desta forma, na análise das capas, não poderemos deixar de observar o caráter históricosocial da formação discursiva, que é a ideologia.

A ideologia é um conjunto lógico, sistemático e coerente de representações (idéias e valores) e de normas ou regras (de conduta) que indicam e preservam aos membros da sociedade o que devem pensar, o que devem valorizar e como devem valorizar, o que devem sentir e como devem sentir, o que devem fazer e como devem fazer. (CHAUÍ, 1981, p. I 13). 
Segundo Eagleton (1997, p. 134), "a ideologia não é primariamente uma questão de idéias; é uma estrutura que se impõe a nós sem necessariamente ter de passar pela consciência". Sendo assim, as posições do capista vão aparecer como partes do dito que delimitam a sua identidade, já que, entre o locutor e a linguagem, existe sempre a ideologia construída de processos de significações que constituem os imaginários. A ideologia tem uma materialidade implícita no discurso da capa e aproxima a relação do imaginário do capista, com a realidade. O sentido dado na construção das formações discursivas é marcado por suas posições e práticas ideológicas.

Por meio da linguagem, o capista argumenta, justifica, simplifica, esquematiza e apresenta caráter codificado, dando uma visão de conjunto não somente do grupo em que vive, mas da sua história de mundo. O papel da ideologia é perpetuar a energia inicial dos sentidos, necessidade ligada a um ato fundador, para um grupo social, de inferir uma imagem de si mesmo, de representar-se, de encenar. A ideologia no discurso publicitário se manifesta, na maioria das vezes, por meio de máximas, slogans, clichês e formas cristalizadas em que a retórica está sempre presente, sendo operatória e não temática, sedimentar. Cada receptor pertencente ao público-alvo movimenta-se para pensar através dela, pois representa, ao mesmo tempo, conservação e resistência às modificações. Por isso, pode-se dizer que o "novo" só poderá ser recebido através do típico, oriundo da sedimentação dos sentidos, memória discursiva, e da experiência social. Entretanto, apesar da cristalização das posições ideológicas, observa-se que toda capa, no processo de sua vida futura, pode enriquecer-se de novos significados, de novos sentidos, sinalizando o movimento do discurso constituido na época da sua criação. Podem continuar existindo sentidos de forma latente ou potencial, que só se revelarão em contextos culturais capazes de acolher e favorecer um desdobramento fecundo por meio do diálogo.

Na construção da capa, o capista preocupa-se com um suposto leitor, um leitor virtual, imaginado por intermédio da pesquisa de identificação do públicoalvo. Ele o identifica quando observa a grande massa heterogênea e seleciona por grupos de interesses, buscando uma suposta homogeneidade para comunicação. O publicitário ou capista, por exemplo, mobiliza estratégias, no nível pragmático e semântico, que facilitem a comunicação a partir de indicações, pistas e formas usadas na sua diagramação, que deixam os espaços disponíveis para a entrada do outro, nos implícitos, pressupostos e subtendidos, pela consciência de que um 
Sujeito assujeitado indivíduo que, através do discurso, é levado a ocupar seu lugar e identificar-se ideologicamente com grupos ou classes de uma determinada formação social (BRANDÃO, 1995). texto é sempre incompleto e reticente. Enquanto isso, o observador-leitor recria e busca compreender o que se oculta na tessitura do texto da capa. A leitura desse observador vai ocorrer mediante aos movimentos contínuos que recortam o interdiscurso, filtrando-o através de uma seleção que possibilite compreender os sentidos possíveis.

Nessa perspectiva, o autor da capa, ao elaborar o seu discurso, se preocupará em indicar ao leitor a maneira como a capa deve ser lida e imprimirá, mediante a sua marca pessoal, um universo de significações resultante do diálogo com esse leitor imaginário. A atividade de leitura, assim como a elaboração da capa, são coenunciações de dois sujeitos, que harmonizam diferentes vozes em busca da unidade e da coerência e reconhecem esses sujeitos, na sua complexa multiplicidade, como seres nem totalmente assujeitados' ${ }^{\prime}$, nem totalmente livres. Tanto quem ilustra como quem redige, quem diagrama a capa, observa e lê dão conta de que a percepção e a compreensão ocorrem através da consciência num processo de significação. Tal processo acontece ao se transladar do plano da expressão para o plano do conteúdo, com todas as limitações pertinentes ao homem, à sua individualidade e ao espaço-temporal do contexto sócio-histórico no momento da enunciação.

capista, no seu discurso, também se utiliza da estética. A estética pode ser um conjunto de princípios fundamentais numa expressão artística em conformidade com determinado ideal de beleza. O capista, consciente desses princípios, preocupa-se em identificar o público-alvo a ponto de selecionar peculiaridades da sua forma de vida e agrupá-las por interesses, para que a mensagem não somente chegue até ele com a objetividade desejada, mas que também o receptor, ao observá-la, seja atraído e seduzido. Para que isso ocorra, é necessário ter em conta esse jogo da comunicação visual, que implica num processo de significação, no qual o sinal é uma forma significante a ser preenchida pelo observado, com possíveis significados.

Como mensagem estética, o autor da capa não poderá prever que sensações devem surgir, provocar ou inspirar no observador, mas, ao identificar o grupo em que esse observador se insere, poderá identificar, as preferências, os interesses, o gosto e as particularidades que provocam, nos participantes de cada grupo, determinadas sensações. Desta forma, poderá despertar a atenção do observador, solicitando-o para várias interpretações ou várias sensações. Por outro lado, as sensações esperimentadas pelo receptor, agradáveis ou não, poderão 
provocar uma visão ambígua e múltipla de significação. Algumas sensações podem ser provocadas sem matrizes combinatórias fixas convencionadas, mas aptas para gerarem inesperadas variações, tratamentos originais, transformando-se num instrumento de conhecimento para o observador. Por isso, os capistas se preocupam com a estética no seu discurso, observando o significante usado e suas possibilidades de interpretação, reconsiderando criticamente as alusões, o dizível e o já dito. Por outro lado, o leitor, poderá ter, também, a sensação de estranhamento, que nada mais é que um efeito resultante da representação divergente das fórmulas fixas, como se aquela representação fosse vista pela primeira vez. Sob uma perspectiva semiológica, Eco (1997, p.52) considera que "[...] a mensagem como função estética é, antes de tudo, estruturada de modo ambíguo em relação ao sistema de expectativa do código". E essa ambigüidade é um dos recursos mais usados nos trabalhos artísticos e um dos mais almejados nos discursos publicitários. No discurso estético, também podemos encontrar uma dupla face, o sentido encontrado pelo observador-leitor e um significado "intervalar", uma existência fronteiriça, um estranhamento que, assim como pode inovar, poderá obscurecer invadindo a sombra.

Em geral, o diagramador da capa seleciona a abordagem dos dados, a argumentação, o estilo, como dizer a mensagem prevista, o tamanho e o formato da capa e a precisão que acredita ser adequada ao leitor virtual. Tudo se passa num jogo simbólico e até lúdico em que o sentido não passa apenas pela palavra e/ou pela ilustração, mas perpassa pelas idéias que estes significados, valores vivos e simbolismos permitem. Como diz Bakhtin, (1993, p.32) "[...] a palavra exprime, cuida da atitude valorativa em relação ao objeto, positiva ou negativa, e, com isso, o põe em movimento, fazendo dele um elemento da eventualidade viva".

Considera-se, também, que a mensagem elaborada pelo capista pode constituir uma redução da informação, visto que representa uma escolha e não outras, dentre os vários símbolos equiprováveis. Mas esse não-dito, o silêncio no discurso, é cheio de significados. É provável que o capista, ao escolher determinado enfoque do texto amadiano para representar, considere-o como o mais objetivo em relação ao que quer chamar a atenção do público-alvo. Consequentemente, o que não foi dito terá motivos para ser silenciado. $\bigcirc$ sentido é essencialmente uma correlação ou uma conotação, e o processo de decodificação sofrerá influências das direções, não só dadas pelo decodificador, como também induzidas pelo autor da capa, pois, no processo da decodificação, o observador pode, 
inconscientemente, seguir a ordenação e o ritmo dados pelo capista, de acordo com a ordem prioritária dos elementos expostos na capa, como tamanhos maiores ou menores dos ícones, cores mais ou menos impactuais ou luminosas, ou a perspectiva, seguindo o gráfico que o capista gostaria que o olhar do receptorleitor- observador fizesse, ao receber as informações da capa.

Ver algo implica determinar-lhe um lugar no todo, uma localização no espaço, uma posição na escala de tamanho, claridade ou distância. Especificamente, estas características são propriedades do campo visual total, como uma forma de apropriação, porque o visto é o descoberto codificado, começa e termina no olhar. As várias qualidades das imagens produzidas pelo sentido da visão não são estáticas, logo, pode-se dizer que a experiência visual é dinâmica, é antes de tudo uma interação de tensões dirigidas. Essas tensões são chamadas de "forças", pois são inerentes às observações feitas com relação a tamanho, configuração, localização ou cor. Durante a percepção, o observador vai chegar espontaneamente a conclusões ou a induções perceptivas derivadas de conhecimentos adquiridos previamente, considerando que a percepção é um campo contínuo de forças, onde as linhas são pontos que se inclinam para uma determinada direção.

Como apenas se vê aquilo que se olha, pois ver é um ato voluntário, como resultado, o observador vê aquilo que está ao seu alcance, o que se sabe e o que se julga afetam o modo de ver as coisas. Além disso, nunca se olha para uma só coisa de cada vez, sempre se vê a relação entre as coisas e o próprio observador, pois a visão está sempre em movimento. Quando o ser humano adquire a faculdade de ver, apercebe-se de que também pode ser visto, logo os olhos do outro se combinam com os seus para tornar crível que faz parte deste mundo visível. É a natureza recíproca da visão que a torna dialógica. $\bigcirc$ observador sabe que vê as capas, inclusive, porque o outro as vê.

A percepção é o elemento mais importante quando se fala de linguagem não-verbal. A percepção visual é o processamento, em etapas sucessivas, de uma informação que chega por intermédio da luz aos olhos, sendo capaz de localizar as três características da luz: sua intensidade ou valor, seu comprimento de onda ou matiz e sua saturação. Quanto à intensidade da luz, pode-se dizer que, através dos bastonetes - células do nosso globo ocular -, temos a visão fotóptica - a visão dos objetos iluminados pela luz diurna - e a visão escotóptica - percepção dos objetos sem iluminação intensa, noturna, com características opostas à precedente, percepção acromática e de fraca acuidade. Através destas percepções é que 
ocorre o contraste de sombra e luz. Já o comprimento de onda da luz vai-nos fazer perceber a cor, através dos cones - células do nosso globo ocular. O sentimento de luminosidade provém do sistema visual, da luminância dos objetos e das reações do comprimento de ondas das cores emitidas ou refletidas. $\bigcirc$ comprimento de onda é que define o matiz, a saturação e a pureza da cor, porque as cores do espectro solar têm saturação máxima. A luminosidade é vinculada à luminância, ou seja, quanto mais elevada for, mais a cor estará próxima do branco. O branco é a cor mais luminosa, por isso é a principal fonte luminosa com a qual lidamos e a união de todas as cores do espectro.

As cores, como já referenciado, podem ser distinguidas em aditivas, mistura de luzes, isto é, um feixe de luzes de cores consideradas primárias - vermelho, verde e azul - RGB, e subtrativas mistura de pigmentos, já que o pigmento absorve a luz e a nossa percepção capta apenas o matiz que é emitido. Logo, cada pigmento adicionado absorve novos comprimentos de onda, tratando-se, portanto, de uma subtração. As cores usadas nas capas são impressas, sendo então subtrativas, pois são pigmentos da tinta da impressão. Os cones retinianos é que vão responsabilizar-se pela absorção de cada comprimento de onda diferente, sendo que, para uma pessoa normal, estes comprimentos vão de $0,440 \mu$ a 0,700 $\mu$, em média. Já o agrupamento das células, da retina ao córtex, vai ser responsável pela variedade da percepção e pelas dimensões essenciais do mundo visual.

Quanto à distribuição espacial da luz - as bordas visuais, os olhos são também equipados para perceber os limites espaciais dos objetos e suas bordas. A borda visual designa a fronteira entre as superfícies de luminância diferente. Esta borda vai mudar a depender do ponto de vista. Por isso, em algumas ilustrações percebe-se claramente a representação da borda visual dos objetos. $\bigcirc$ sistema visual está equipado para reconhecer não só a borda visual dos objetos, mas também a sua orientação, fendas, linhas, ângulos, segmentos, superposições, cores, sempre simultaneamente, por isso a percepção de um objeto afeta a percepção dos outros. A percepção não é um processo instantâneo, certos estágios são rápidos, outros mais lentos, e o processamento da imagem se faz sempre no tempo, a exemplo da adaptação visual dos movimentos do globo ocular - regulares e irregulares, de compensação e de perseguição. Como o mundo em que vivemos sempre tem a mesma aparência, isto nos dá o parâmetro referencial e a percepção dos aspectos invariáveis do mundo como: o tamanho dos objetos, formas, localizações, orientações e propriedades das superfícies, que vão estabelecer a noção de 
constância perceptiva. Por exemplo, na capa inglesa da editora Abacus, ano 1984 , pela constância perceptiva, percebe-se o destaque dado ao pássaro, pelo fato de o ilustrador colocar o pássaro em tamanho muito grande com relação à figura de mulher representada ao lado.

Os efeitos psicológicos que a forma e a cor provocam no ser humano são chamados de percepção, diferenciando de sensação, simples estimulação dos órgãos sensoriais, porque, no momento da percepção e captação da imagem pela visão, os conhecimentos e experiências anteriores, o imaginário e a visão de mundo do observador vão provocar a significação, o olhar. Tanto as cores como as formas vão ter influência sobre o psiquismo humano e vão produzir efeitos de sentido. A influência psíquica da cor tende mais para aspectos emotivos, enquanto a forma tende para a predominância lógica. Qualquer representação gráfica, por mais fiel à realidade, precisa nos pormenores e particularizada, é sempre uma interpretação e, por isso, uma tentativa de explicação da própria realidade. O olhar do capista representado é o resultado de uma multiplicidade de escolhas que passam pelo filtro do código e por sucessivas aproximações para sua construção. São escolhas entre as qualidades visivas, e estas escolhas serão determinadas e impostas pelo tipo de informação que se quer dar, pelo grau de comunicação que se deseja estabelecer.

Dessa forma, qualquer traço na superfície é considerado como sinal e a construção de um discurso com vários sinais será cada vez mais dilatável para cobrir a possibilidade expressiva, enquanto sua escolha e organização vão trazer a construção de sentido que, junto com a leitura do observador, irá manter a dialogicidade. O olhar do observador, a sua percepção e as suas orientações cognitivas, resultado da sua seletividade e visão de mundo, vão-se modificar segundo o contexto sociocultural. A linguagem não-verbal é mais imediata que a linguagem verbal, mas também é arbitrária, inventada e cultural. É importante aprender a reconhecê-la, empregando as propriedades do sistema visual, usando a abordagem pragmática por meio da confrontação de hipóteses e a abordagem cognitiva em que fatores sociológicos, psicológicos e semiológicos vão influenciar na interpretação e até mesmo na aceitação da imagem. A partir dessa dialogicidade, é possível chegar aos atos de pensamento, privilegiadamente pelo ato "visual", considerado o mais próximo do pensamento. Todos os sistemas usados para representação do mundo foram escolhidos por algo além da simples capacidade de informação e, conscientemente ou não, cada sistema é destinado a exprimir certa 
idéia, certa concepção visível. A representação de espaço e tempo, na imagem, é, quase sempre, uma operação determinada por uma intenção mais global de ordem narrativa, mediante a diegese, uma construção imaginária, um mundo fictício que tem leis próprias, mais ou menos parecidas com as leis do mundo natural ou pelo menos, com a concepção variável que dele se tem.

"Toda construção diegética é determinada em grande parte pela sua aceitabilidade social, logo por convenção, por códigos e pelo simbolismo em vigor na sociedade", como diz Aumont (1995, p.248). O sentido da imagem, como elemento representativo do objeto, possui sempre uma comparação implícita com múltiplos sentidos. A figura artística também é um enunciado, uma configuração mais ou menos única, que se diferencia da regularidade do discurso pelo fato de procurar produzir sentido de um modo mais original. Passa a ser considerada mais interessante quanto mais nova e mais inédita, ao contrário dos chamados "chavões", plágios, cópias ou contaminação do icônico, muito encontrados nas representações gráficas. Por outro lado, a expressão do criador, como representação regulada e reconhecida socialmente, pode ser comparada a um organismo vivo. Os taxemas são signos indicadores e atribuidores de lugares, tais como roupas e postura do corpo, que se modificam no curso da interação.

Já os gestos e mímicas são considerados expressivos por reproduzirem o estilo de vida, hábitos, formas usuais e costumes coletivos. Diversos aspectos da cultura afetam sensivelmente anexos, laços e formas de interação social que regem o comportamento em sociedade, como os movimentos corporais, em particular, o movimento dos olhos e as características dos olhares. Cada gesto situa os membros de uma dada comunidade e, ao mesmo tempo, trai suas peculiaridades, o que os constitui diferentes e individuais, socialmente.

O gesto é uma ação corporal visível que transmite certo significado por meio de uma expressão voluntária. Codificado, difere da pura manifestação emotiva que, a exemplo de tipos e cacoetes, não é considerada parte intencionalmente significativa de um ato de interação social. Atos ou ações práticas não são gestos na acepção semiótica do termo, ainda que encenem a intenção de exprimir um sentimento. $O$ gesto é uma representação intencional codificada pela sua função referencial, podendo ser-Ihe atribuida uma função fática.

A cinésica, por exemplo, estudo sistemático dos movimentos corporais observáveis em situação de comunicação, torna cada detalhe do corpo um elemento significante que, interpretado, corresponde a um significado. Este gesto, 
quando fixado, dá forma mais ou menos definitiva para certo uso social como reprodução da realidade, passando a ser um registro da realidade visível, como no desenho e na fotografia.

A fotografia é considerada a arma suprema da representação, já que oferece uma legitimidade, ao produzir automaticamente uma vista opticamente perfeita, um "embalsamento" da realidade. Nesta perspectiva de registro automático da realidade, a foto, como discurso nas capas, pode tornar-se uma armadilha, porque contém a intenção do fotógrafo na captação do movimento, ângulo e luminosidade convenientes e a expectativa do observador a que será destinada. Portanto, na dialogicidade continua os efeitos sócio-histórico-culturais dos sujeitos, como confirma Aumont (1995, p. 192) nas suas reflexões sobre o simbólico:

O contexto simbólico revela-se também necessariamente social, já que nem os símbolos e nem a esfera do simbólico em geral existem no abstrato, mas são determinados pelos caracteres materiais das formações sociais que os engendram.

Dessa forma, o capista vai construindo o seu discurso, utilizando textos linguísticos, fotografias, desenhos ou pinturas, ou seja, linguagens verbais e nãoverbais, sempre com o objetivo de informar, mas também de seduzir e convencer o observador-leitor e possível consumidor.

\section{o Verniz e $a$ Sedução}

Um dos recursos usados como artifício para realçar as cores impressas e dar beleza à produção gráfica e artística é o verniz, uma preparação não pigmentada, translúcida e brilhante, que dá uma aparência superficial de brilho. Este recurso sempre foi muito utilizado nas pinturas e, hoje, é considerado um dos melhores efeitos para acabamento gráfico de embalagens e capas de livros e revistas para agregar valor ao impresso e propiciar um aspecto diferenciado e de melhor qualidade ao produto. Atualmente, existe no mercado uma variedade muito grande de vernizes, como os que dão aspecto de brilho, transparência, aroma, textura, até os que fazem a cor impressa anteriormente se modificar com o toque das mãos ou ao ser exposto a temperaturas frias ou receber o calor do sol. Assim, o capista tem a possibilidade de escolher a sensação desejada, tentando transmitir 
uma falsa idéia de realidade, no sentido de seduzir cada vez mais o possível consumidor-leitor. Além desse artifício, o capista utiliza muitos outros, sempre com a intenção de encantar o observador-consumidor.

A imagem, no discurso jornalístico e publicitário, devido à sua polissemia e através da sua cadeia flutuante de significados, necessita, na maioria das vezes, ser sustentada por um texto verbal com menor ambiguidade. Na publicidade, a linguagem visual é de suma importância, pois objetiva criações de imagens de vida peculiares a cada observador do público-alvo. A relação entre os produtos divulgados e a sua repercussão em termos de consumo tem que ser ligada, diretamente, à configuração de imagens de vida a que esses "produtos" se associam estreitamente. É necessário observar que a linguagem da propaganda fica desatualizada e necessita, por isso, constantemente ser renovada. É imprescindível que o conjunto de signos usados apresente uma determinada "personalidade cultural", um conjunto de traços comuns a todos os membros de um grupo cultural, e reflita valores e atitudes sociais. Esse processo diário dos publicitários, no momento da sua criação, faz com que a propaganda, ao ser veiculada, influencie e seja influenciada pelo meio em que atua, refletindo, assim, o pensamento coletivo e contribuindo para aprimorar ou deslocar o pensamento do público observador. $\bigcirc$ discurso publicitário se inscreve em orientações ideológicas implícitas, que guiam a maneira como se selecionam os fatos e se determina o tratamento a eles dispensados.

Uma das etapas do marketing, assim como da propaganda, é a promoção de vendas, que explora os mecanismos psicológicos da compra, funcionando por intermédio de motivações e impedimentos. $\bigcirc$ ato da compra está ligado ao peso das motivações em relação aos impedimentos. Contudo, o comportamento da compra também pode ser explicado em termos de elementos racionais, irracionais ou emocionais. Os fatores racionais conscientes levam o consumidor a uma decisão abalizada, ligada ao objeto, enquanto os fatores emocionais inconscientes estão ligados não diretamente ao objeto, mas à imagem a ele associada, como sua importância, discurso, estilo, marca, relações com a profissão, etc. Esse comportamento, na hora da compra, vai-se modificar a depender dos dados socioculturais e das informações que os consumidores possuem a respeito do produto.

mecanismo da promoção de venda será ativado sempre que os impedimentos forem muito intensos ou as motivações muito fracas, oferecendo ao consumidor motivações suplementares e uma resposta às objeções. As promoções 
2 Prospect-cliente ou comprador em perspectiva. de vendas podem acalmar as apreensões do prospec ${ }^{2}$ e superar os impedimentos psicológicos que formam uma barreira à compra, ou oferecer uma motivação suplementar. Um elemento decisivo para promover a venda é a embalagem, além das funções de recipiente ou invólucro destinado a acondicionar mercadorias, a fim de protegê-las de riscos, facilitar seu transporte, estocagem, venda e consumo. Além das funções físicas da embalagem, esta tem como recurso significativo identificar, diferenciar e exibir o produto aos olhos do consumidor. Nos pontos de venda, na hora da compra do produto, é que o consumidor decide sua preferência, mesmo que a marca do produto esteja respaldada por forte campanha publicitária. Logo, sua escolha dependerá, em grande parte, de uma embalagem apropriada e convincente.

Uma boa embalagem pode ser responsável pela liderança desse produto no mercado. A embalagem age como uma vitrine, refletindo as características intrínsecas do produto, bem como o estágio de desenvolvimento em que se encontra seu fabricante e, consequentemente, a sociedade como um todo. Por isso, recomenda-se que a embalagem não seja apenas graficamente satisfatória, mas que mantenha a integridade do produto e interaja com ele em perfeita harmonia.

Portanto, o lugar da embalagem é o lugar do produto, da indústria e do marketing, e o que vai interessar neste capítulo é o lugar do marketing, da amplitude mercadológica, isto é, como a embalagem chama a atenção, transmite as informações, vence a barreira do preço e desperta o desejo de compra no provável consumidor.

Há vários tipos de embalagens: de transporte, uso, display, conjunto, unitária e de consumo. As que interessam, neste estudo, são as de consumo, porque efetivam o contato do produto com o consumidor. As capas dos livros são consideradas embalagens de consumo.

Como dito anteriormente, um dos fatores essenciais no momento da aquisição do produto é o processo decisório. Trata-se do momento em que o indivíduo analisará os prós e os contras para a aquisição do produto ou se deixará levar pelo impulso irresistível, comprando itens de que talvez não usufrua jamais. A hora da tomada da decisão começa na infância e acompanha o homem até o fim dos seus dias, e, de certa forma, a decisão mercadológica sempre acarreta ganhos e gastos. A freqüência e a importância das escolhas variam de acordo com variáveis como idade, status social e outras. Há duas abordagens quanto ao comportamento do consumidor: a distributiva - que dá ênfase aos consumidores quantitativamente, 
e a analítica - que dá ênfase à forma pela qual a decisão é tomada em termos de um processo que obedece a uma sequência, que leva ao ato de compra. Esta sequência consiste no reconhecimento do problema na procura externa, na avaliação de alternativas, no processo de compra e na avaliação pós-compra. Tal processo, no entanto, não segue obrigatoriamente todos estes passos no nível do consciente e pode ocorrer sem que o consumidor tenha consciência do problema.

comportamento pode ser estimulado em função de um input físico ou social que, combinado com fatores internos, levará à compra. Esse comportamento forçará o indivíduo a uma procura externa de alternativas para aumentar seus conhecimentos a respeito do produto, e as informações obtidas devem ser avaliadas e comparadas com as já existentes, passando para a seletividade perceptiva, motivações, valores, personalidade, e a atitudes que levam ao ato de compra. Finalmente, a forma mais comum e mais simples do processo decisório é aquela em que o problema é reconhecido, havendo, em seguida, a aquisição. As informações necessárias para esse processo decisório devem estar expostas na embalagem por meio da rotulagem.

A capa, então, funciona como um rótulo, sendo utilizada para atrair e informar o consumidor sobre o que existe na obra literária e o discurso nela contido, consequentemente, influenciará no processo decisório do consumidor. A capa como rótulo deverá, também, estar subdividida em painéis nos quais deverão estar expostas as informações sedutoras para o consumidor, as que são importantes para o produtor e as de natureza obrigatória impostas pelas instituições fiscalizadoras das embalagens, as quais, normalmente, interessam muito mais ao consumidor por serem mais verdadeiras.

Na construção dessa rotulagem, o publicitário deverá procurar chamar a atenção, transmitir a informação básica para a compreensão do que está sendo oferecido, ressaltar os atributos, como também agregar valores a esse produto, de forma que encante, seduza e conquiste a simpatia e o entusiasmo do consumidor. Isso atualmente acontece de tal forma que, como resultado, dificilmente serão encontrados como líderes de venda no mercado, os produtos que não tenham embalagens sofisticadas, bonitas e sedutoras.

Outro aspecto observado é a qualidade da embalagem que ajuda na formação da imagem da empresa que a fabricou, incentivando, dessa forma, a utilização de novas tecnologias para aumentar o requinte na produção editorial e, ao mesmo tempo, para destacar a representação da empresa no mercado. 
Portanto, nas capas de Gabriela, Cravo e Canela, serão observados, através da embalagem-rótulo, os elementos que seduzem para a compra do livro, o "verniz" usado pelo capista para encantar o consumidor, e a relação das informações obrigatórias, que estabelecem uma harmonia e um contrato com o produto interno, a obra de Jorge Amado.

\section{a Harmonia $e$ o Contrato}

Percebe-se que existe, na maioria das vezes, uma relação entre as partes de um trabalho, artístico ou literário, uma harmonia entre formas, ritmo e cores, de modo que resulte numa boa disposição e ordenação entre seus elementos. Comumente, a harmonia das cores é confundida com a combinação, mas harmonia é o equilíbrio de um conjunto de partes para formar a totalidade em relação aos elementos que se integram. Para que surja a harmonia, é necessária a superação dos conflitos das forças contrárias, expressas pela presença e ação das cores complementares que, impressas juntas, uma ao lado da outra, aparecem com mais intensidade e completamente distintas, apesar de todos os matizes serem neutralizados ao se misturarem na paleta. Normalmente, há uma grande dificuldade de conseguir harmonia para quem trabalha com cores puras, como também para que as cores conflitantes sejam modificadas. $\bigcirc$ artista costuma misturar essas cores puras com a cor preta ou com a cor branca para diminuir a vibração do matiz e, consequentemente, lograr uma harmonia entre elas.

Num trabalho publicitário gráfico, a harmonia das cores e dos signos é extremamente importante, pois o resultado do trabalho deverá ser um conjunto harmonioso e impactual para se destacar em meio a tantas comunicações a que o consumidor está exposto. $\bigcirc$ capista deverá estar atento a toda sorte de conflitos, não somente quanto à harmonia das cores, como também quanto à harmonia das formas utilizadas, com o sentido que essas formas devem representar.

Já foi mencionado que as pessoas que convivem num mesmo meio social e possuem um mesmo corpo de práticas e códigos, estão, presumivelmente, envolvidas num contrato que estabelece um determinado uso de representações comuns a todos que as utilizam e esse tipo de contrato funciona no momento em que o capista seleciona os signos para se fazer compreender por determinado 
público. Mas, quando os editores se envolvem no resultado do trabalho do capista, um novo contrato passa a ser estabelecido.

Os editores, na maioria das vezes, recomendam que a embalagem do livro seja sempre um objeto atraente e bonito, com a finalidade de seduzir aqueles que entram na livraria, os possíveis consumidores. Enquanto o capista está preocupado em estabelecer equivalências visuais, que cheguem o mais próximo das relações feitas na cultura do público-alvo, sem perder a fidelidade ao contexto histórico-social do autor da obra literária num trabalho não somente técnico ou sistemático, mas cultural. $\bigcirc$ contrato com a editora força-o a lidar com situações de difícil representação, o que dificulta bastante o seu trabalho, sem falar nas capas de livros em série. Para que o leitor identifique determinado exemplar ou número da série, é necessário manter uma uniformidade no conjunto e, ao mesmo tempo, uma diversidade para destaque da seriação. $\bigcirc$ momento da criação da capa é um desafio para quem o faz, pois, além de fazer surgir o "novo", este novo poderá agir sobre o observador-consumidor como um fetiche, como sobrenatural.

O capista deverá demonstrar para os editores contratantes a eficiência das capas elaboradas, para também atingir o objetivo da empresa, que é vender. A composição criada para embalar o livro é uma proposta que, normalmente, será selecionada de várias outras criações apresentadas à editora, mas os requisitos para escolha nem sempre são os de fidelidade à obra literária e ao contexto cultural do autor do livro, pois o objetivo maior é a venda. Outro elemento que entra na relação é o gosto pessoal dos editores envolvidos com a produção, que sempre interfere de maneira imponderável, já que sua visão, olhar e interesse são com a venda e não com a representação do texto literário.

Para a aprovação de uma determinada criação elaborada para alguma capa, os editores observam, principalmente, o custo/benefício da edição, interferindo consequentemente no resultado do trabalho. Muitas vezes, a limitação da verba modifica os resultados obtidos visualmente, distanciando as relações e a sintonia com os objetos representados. Tamanho e formato do livro, tipo de papel usado e redução da quantidade de cores da impressão, assim como o tipo da encadernação, são elementos que modificam o custo do livro e, ao mesmo tempo, interferem na qualidade da mensagem da capa, aproximando-se ou se distanciando do objetivo almejado pelo capista na comunicação com o público-alvo.

O autor da capa de um livro, portanto, deverá elaborar o seu trabalho mediante três parâmetros: leitura e interpretação do texto literário, público-alvo ao 
qual se destina aquela publicação e imposições feitas pela editora que irá publicar o livro. Quanto à interpretação do capista, alguns recebem da editora a obra literária para ler, ou na língua do próprio autor que, quando acontece ser a sua própria língua, torna mais fácil sua compreensão, ou ainda num idioma que pode ser desconhecido ou de pouco domínio. Outra forma de acesso à obra literária original é através de traduções, o que já modifica o texto original devido às coenunciações. Também os releases são muito usados pelos editores, para dar informações aos capistas sobre os livros que deverão ilustrar, ou as capas que irão criar. Esses releases são informações resumidas sobre o conteúdo do livro e que, na maioria das vezes, o capista lê. Este, quando tem acesso, conversa com o autor para maiores esclarecimentos. Muitas vezes, acontece uma leitura bastante superficial da obra literária, além da interferência da terceira pessoa, autora do release, pois não se pode esquecer que, em qualquer discurso, o autor seleciona o que vai informar de acordo com o seu olhar, já que ele é quem enuncia.

Então, o trabalho final da capa é resultante de várias representações. Amado apenas pintou com palavras e quem as representou, através do release, assim o fez para que o publicitário-capista realizasse o seu trabalho, que já é outra representação. Portanto, no processo de construção das capas, provavelmente há uma sequência de representações com sentidos diferentes do sentido imaginado e sugerido por Amado. Tais representações fazem pensar no retorno às origens como função de apresentação, mesmo sabendo que, tendo uma obra literária como origem, nada se tem de "certo". Sobre isto, as palavras de Derrida (1972, p. 155):

Como encampar uma produção atingida pelo "mal da repetição", pelo que na repetição se desdobra, se redobra, repete a repetição, e com isso, separado da "boa repetição"(a que apresenta e reúne o ente na memória viva) pode sempre, abandonado a si próprio, não mais se repetir.

Quanto às capas elaboradas através de traduções, existe também uma coenunciação que pode gerar modificações radicais e, com isso, afetar consideravelmente não só a leitura do publicitário que irá elaborar a capa, como também a percepção do leitor. Traduzir é transpor uma mensagem de um código ou sistema de signos para outro. No momento em que o tradutor lê e capta a significação de um texto automaticamente, existe também uma dialogicidade referente à mensagem elaborada por Amado e uma interpretação e entendimento do tradutor, 
segundo sua visão de mundo e sua experiência perceptiva. Nessa leitura, acontece a dialogicidade, como Sousa (1995, p.203) deixa claro nesta afirmação:

Nos contratos de leitura, o receptor já está contido na medida em que a emissão ao imaginar que "ele sabe" constrói o contrato de acordo com certas modalidades (identificatórias, imaginárias, culturais) que exigem que o receptor trabalhe ativamente no interior do discurso. Nesses termos ele é ativo porque age no interior do discurso, não só sendo interpelado, mas também se reconhecendo! O seu ler também é um fazer, porque o contrato, explícita ou implicitamente, estrutura-se também no reconhecimento da existência da esfera do "outro", do qual também são extraídas as regras com que ele é interpelado.

○ contexto sócio-histórico-cultural e também as implicações de ordem individual, não só culturais como linguísticas, originárias do confronto de duas línguas de estruturas diferentes, podem induzir o tradutor a criar soluções, adaptações e assimilações que o levam à libertação das normas e ao uso da língua de chegada. A transferência de um texto, principalmente literário, de uma língua para outra, causa enormes polêmicas. Existem várias modalidades de traduções ("fórmulas" de tradução já instituídas), mesmo assim não se pode ignorar que a tradução é um processo que tem a língua como matéria-prima, mas também como produto, e, como toda manifestação de uma língua num discurso, a tradução também está sujeita a contingências de ordem individual do tradutor, cultural ou linguística, mas originárias sempre do confronto de duas culturas diversas. Então, haverá tantas versões diferentes quantos forem os tradutores, pois cada tradutor, assim como capista, elabora o seu discurso dialogando com a matéria-prima do seu trabalho, o texto de Amado, mas representa-o segundo seu conhecimento e seu estar no mundo.

Alguns autores apontam três abordagens para a tradução: a matricial, considerada transparente, que acompanha o texto original como guia, e não como texto autônomo; a assimilativa, na qual o tradutor constrói uma adaptação em que os referenciais básicos passam a situar-se no âmbito dos usos e costumes linguístico-culturais da língua em que o trabalho foi traduzido; e a criativa em que o autor assume a coautoria sem disfarces, formulando na língua de chegada suas leituras, vivências e sensibilidades. Grandes são as dificuldades dos tradutores que têm como trabalho línguas que se originam de uma cultura híbrida, formada de várias culturas completamente diferentes, pela mistura de costumes, hábitos, comidas, músicas, expressões idiomáticas e outras características de diferentes 
povos. A carga antropológico-cultural do significante sugerida pelos escritores que convivem com essas culturas, dificilmente será recuperada pelo tradutor, que não encontra equivalência em sua cultura.

Segundo Pedreira ( 200 I, p.27):

O processo de formação identitária deflagrado pela tradução é, portanto, uma faca de dois gumes, que constrói uma representação doméstica para um texto de uma cultura estrangeira e pode gerar simultaneamente uma compreensão conformada por uma posição ideológica sedimentada sobre interesses, códigos, canones e agendas próprios de certos grupos sociais.

Então, mesmo que o tradutor consiga se aproximar bastante do significante da língua de origem da obra literária, considera-se impossível traduzir a musicalidade, o ritmo e a originalidade de determinadas expressões. Estas dificuldades fazem pensar no autoritarismo da tradução, quando o receptor torna-se passivo à coenunciação do tradutor por desconhecimento da obra original. Por outro lado, existem signos cuja carga cultural é mais fácil de ser percebida, ajudando o trabalho da tradução, porém a maioria tem uma amarração cultural ao grupo que os utiliza, ou neles está representado, fazendo crer na sua intraduzibilidade. Daí se poder afirmar que a relação da tradução é a relação da diferença. Venuti (1998, p. 68) observa:

Circulando pela Igreja, pelo Estado e pela escola, uma tradução pode ser bastante poderosa para a manutenção ou revisão de toda a hierarquia de valores da língua alvo. O caráter conservador ou transgressor da tradução será determinado pelas estratégias discursivas aliadas aos fatores de recepção, que incluem desde a ilustração da capa à publicidade e às resenhas, até os usos que dela serão feitos em instituições sociais ou culturais, sem esquecer a maneira como ela é lida e ensinada.

A língua, enquanto idioma, está ligada à noção de país, de pátria, de povo e de cultura, por isso é também conhecida como critério de reconhecimento e identidade nacional e cultural. Ao ser traduzida sem preservações, passa a existir um total apagamento das delimitações nítida e historicamente demarcadas, perpetuando um estranhamento e resultando, consequentemente, em "exotismo" da cultura traduzida.

Pode-se observar que o título Gabriela, Cravo e Canela sofre modificações radicais em algumas edições traduzidas, distanciando-se da obra original, haja vista 
títulos como Mulatka Gabriela (Mulata Gabriela), da Tchecoslováquia (Editora Odeon, 1967), e Gabriela, fille du Brésil (Gabriela garota ou filha do Brasil), da França (Editora Seghers-Linter, 1959), que foram modificados de acordo com o interesse das editoras e ancorados em uma representação não-verbal da personagem Gabriela na capa do livro. O modelo impresso pode parecer uma representação da Gabriela, mas pode ser visto como um estereótipo da mulata brasileira para os observadores-leitores da Tchecoslováquia, que a desconhecem. O modelo colocado nessa capa, junto ao título mulata brasileira, é uma pintura surrealista de autoria de Rufino Tamayo, muralista mexicano, que, em suas pinturas, costumava misturar figuras primitivas do México com imagens futuristas. No modelo impresso na capa francesa, assinado por Di Cavalcanti, pintor brasileiro, colocado abaixo do título Gabriela, garota ou filha do Brasil, pode passar a ser uma representação da mulher brasileira para os leitores da França. Os que não conhecem as mulheres que nascem e vivem no Brasil, e, ao observarem ser a ilustração feita por um artista plástico brasileiro, podem passar a aceitar o modelo da ilustração impressa como exemplo da mulher brasileira, considerando o suposto conhecimento do ilustrador.

Na publicidade, geralmente, o título sugere, a ilustração demonstra e o texto persuade e convence. Quando o observador-leitor lê o título, faz sua suposição e, vendo logo abaixo uma imagem, imagina que aquela representação é a demonstração da sugestão do título. A ilusão se realiza com mais facilidade quando se organiza uma situação para que seja esperada.

Por outro lado, a ilusão pode ser, também, mais eficaz, quando as formas utilizadas já são socialmente admitidas e até desejáveis, confirmando um estado imaginário particular de determinado grupo. É preciso estar atento a esta prática, cheia de riscos, pois existem marcas ideológicas que funcionam como marco estrutural das cognições sociais. Gabriela, cravo e canela é uma obra literária escrita por um dos escritores mais traduzidos do Brasil e que, no seu texto, fala da Bahia e, por ilação, do Brasil, país que possui uma carga cultural marcada pela mistura de várias raças. Amado, nesse romance, retrata a diversidade de uma cultura proveniente das várias origens desse povo de características regionais marcantes. A experiência literária propicia conhecimento do mundo aos homens, e o leitor, na ação da leitura, é um caçador de signos, um intérprete. Sendo assim, algumas das narrativas literárias, nas quais ocorreram problemas de tradução, provavelmente perderam sua função de fazer ver, e podem ter passado a serem mímicas. 
A mímica pode ser simultaneamente semelhança e ameaça, problematiza os signos de prioridade e, na maioria das vezes, há um reconhecimento parcial do objeto, parecendo quase o mesmo, mas não exatamente. Bhabha (1998, p. 135) refere-se à mímica como metonímia da presença, afirmando que ela "[...] cruza as fronteiras da cultura da enunciação através de uma confusão estratégica dos eixos metafórico e metonímico da produção cultural do sentido". A mímica é uma forma de semelhança que diverge da presença, expondo-a em parte, e, ao mesmo tempo, é uma ameaça porque produz efeitos de identidade conflituosos, discriminatórios e fantásticos. No momento em que isso acontece na tradução do romance amadiano, e na conseqüente capa que o embala, esse livro pode estar perdendo a sua autoridade representativa.

No processo de tradução, há sempre colisões superficiais de significações e oposições de sentidos que não podem ser traduzidos, de uma cultura para a outra e, consequentemente, as formas satíricas podem ter o seu sentido modificado pelas suas sutilezas. As singularidades do Brasil, país de origem de Jorge Amado, e especificamente as da Bahia, podem não aparecer no texto traduzido por desconhecimento do tradutor, resultando em efeitos caricaturais e exagero de algumas características para fácil reconhecimento e identificação do novo públicoalvo. $\bigcirc$ uso dessas caricaturas, simulacros e estereótipos na tradução da literatura amadiana irá perpetuar, em outras culturas, o imaginário sobre o povo brasileiro. $\mathrm{Na}$ emergência da interpretação do texto literário, o capista perpetua o imaginário do leitor estrangeiro, quando influencia nas representações através da utilização do discurso sobre o Brasil, já instituído no país de chegada. Nesse discurso, o olhar do sujeito que o fez está sempre presente, sendo usado como verdade mesmo em proposições diversas, dificultando as diferentes interpretações e perpetuando o imaginário pelo desconhecimento e distanciamento da realidade.

Trata-se de um discurso que possui um vínculo interno com um passado que não cessa nunca e se conserva no presente, não permitindo o trabalho da diferença temporal e bloqueando a purificação da realidade, apesar das últimas formas e aspectos que possam ter tomado.

Esse discurso apaga ao mesmo tempo em que atualiza, perpetuando o discurso de dominação cultural. Quando um publicitário se utiliza do discurso da capa para representar um romance, ou um personagem de um romance brasileiro, fica subentendido, para o observador-leitor, que o autor do discurso enuncia como quem conhece e sabe o que diz. E o observador-leitor, ao assumir a repre- 
sentação baseada no imaginário do autor da tradução ou da capa, através da dialogicidade, pode admitir o modelo apresentado, relacionando-o com as informações baseadas no discurso sobre o Brasil presente na sua cultura. Então, podese concluir que, nas representações das capas, ocorre quase sempre um comprometimento do texto literário resultante da tradução, já que o significado se encontra na trama das convenções que determinam, inclusive, o perfil, os desejos, as circunstâncias e os limites do próprio observador-leitor. E como consequência desse comprometimento o capista fará a capa segundo o que o texto traduzido representa, provavelmente outro texto, não mais o discurso primeiro, o texto amadiano.

Quanto ao segundo plano, o público-alvo ao qual se destina a capa, o destinatário, pode-se observar que, normalmente, quando o autor da criação da capa seleciona os signos para colocar no seu discurso, procura relacionar cada signo com o que o público pode identificar. Ao mesmo tempo, encontra dificuldades com a representação dos personagens híbridos, especialmente modelos que não fazem parte do contexto sociocultural do público-alvo. Por esta razão, o capista irá substituir os conceitos cristalizados na cultura de origem da obra literária, por outros presentes na cultura do público-alvo. Há um processo de modelização, principalmente, no momento em que o capista constrói os modelos, pensando em uma possível sedução do leitor e/ou nas expectativas desse leitor. Nesse instante é que entra o "novo", e o perigo é que, no momento de observação da imagem elaborada na capa, muitas vezes, esta imagem é a única referência nãoverbal usada para enriquecer a compreensão do leitor. Isto poderá levar espontaneamente o observador a conclusões ou a indicações perceptuais, derivadas de conhecimentos adquiridos previamente, induzindo-o a interpretações, muitas vezes, distantes do texto literário. O capista constrói um discurso que não deixa de ser discriminatório, pelas escolhas dos signos, e autoritário, pela sedução que impõe. Utiliza-se de requintes para dificultar a percepção dos argumentos racionais do público no momento decisório da compra e aproveita o estético para atrair e seduzir.

No discurso publicitário usado na capa da editora Abacus (Londres, 1984), a forma plástica mostra a imagem de uma mulher de tez clara, cabelos cacheados, com uma flor vermelha na cabeça, usando um vestido de estampa delicada nas cores rosa e violeta, e com as mãos abertas, libertando um pássaro amarelo e preto. Em primeiro lugar, a figura e os índices - flores e pássaros - indicam não 
ser de um país europeu, mas de regiões tropicais. A articulação também da mulher com elementos da natureza pode indicar um rebaixamento da mulher e da cultura em que vive, como ser humano pouco intelectualizado, ligado aos instintos. Entretanto, esses elementos icônicos escolhidos para ilustrar o romance, nessa capa, lembram a personagem Gabriela, no momento em que liberta o pássaro recebido de Nacib, como narra Jorge Amado. A forma de uma mulher jovem com as mãos abertas, na cinésica, evidencia submissão, bondade e a impressão de uma pessoa não ameaçadora, o que o gesto de libertação vem reafirmar. Como a cor produz uma experiência essencialmente emocional, enquanto a forma corresponde ao controle intelectual e lógico, o vermelho da flor, na cultura brasileira, pode lembrar ao observador energia, vibração, paixão, amor ardente, exibição sexual e atração, por ser a cor de maior comprimento de onda do espectro, a que causa mais impacto, a observada mais rapidamente e que chama mais atenção. A flor, elemento da flora, aponta para a ingenuidade, produzindo a relação entre cultura e natureza e se instala num jogo polissêmico, pois, por ser de cor vermelha, produz efeitos de sentido que podem representar sedução e adorno e, psicologicamente, poder sexual e paixão, por estar no cabelo, o que já é uma "pista", que antecipa a atmosfera da narrativa na perspectiva da personagem Gabriela. Percebe-se que o modelo usado nessa capa apresenta características de uma mulher morena porque, provavelmente, seria mais fácil a identificação com o público-alvo, assim como os artifícios usados na imagem, a flor vermelha e o pássaro, podem ter sido usados para seduzir o observador para o que se passa em regiões tropicais.

Tais escolhas, provavelmente, foram determinadas e impostas pelo tipo de informação que o capista quis dar, e pelo grau de comunicação que ele desejava estabelecer, confirmando a afirmação de que nenhuma representação é ingênua, pois, na sua maioria, os autores trabalham a linguagem tendo em vista conquistar a adesão da atenção do público.

Nessa análise, é fundamental aprender a reconhecer o emprego das propriedades do sistema visual, utilizando a abordagem pragmática por meio da confrontação das hipóteses e a abordagem cognitiva em que os os fatores sociológicos, psicológicos, semiológicos vão influenciar na interpretação e até mesmo na aceitação da imagem, como afirmam Pereira \& Neto (|993, p.23|)

[... ] as convenções não podem, portanto, restringir-se às representações. Devemos entendê-las, enquanto ideologia, como resíduos extra-semióticos de valores e 
crenças geradoras de dominação social. O que importa não está nos signos, e sim no que - vindo da exterioridade social - os constitui enquanto não só expressão política e social, mas também como instrumento de poder e subjugação.

Quanto ao terceiro plano - as imposições feitas, pela editora, para a publicação do livro -, observa-se que, ao selecionar o capista, esta o legitima como quem sabe ler e sabe fazer, e, utilizando os argumentos da sua autoridade intelectual, impõe-Ihe que construa modelos identificáveis pelo público-alvo. Com isto, ajuda a perpetuar esses modelos e mantém sentidos pré-construídos, ou deixa o leitor no limiar do imaginário ao relacionar esse modelo com as referências do texto literário. Na maioria das vezes, através do discurso estético, a editora poderá estar disfarçando um discurso hegemônico e disciplinador, selecionando o que não interessa em termos ideológicos e de vendas. Através dos múltiplos e variados discursos das diferentes capas, as editoras também tornam a obra literária multirreferencial e ainda se tornam responsáveis pelo destino intelectual da "nação", quando criam tendências, selecionam autores e obras, valorizam ou não o autor e a obra por motivos de ordem política, pelas qualidades "artísticas" ou pela quantidade de obras vendidas. Por isso, faz-se necessário pensar a respeito de colocações como a do editor baiano Gumercindo Dórea, no III Encontro de Editoração na Bahia (1993, p.45):

Numa das Bienais Nestlé, a Mesa formada, citavam-se todos os grandes autores brasileiros vivos, mas não era citado Adonias. Uma pessoa presente levantou-se e disse: "Por obséquio, os senhores se esqueceram de colocar no rol dos autores citados o nome de Adonias Filho" O presidente da Mesa envergou a sua carapaça, virou e disse: "Nós não citamos aqui nesta Mesa homens que compactuaram com a Revolução de 1964". Houve aquele silêncio. Eu não estava e quem me contou isso foi a pessoa que fez a interrogação, mas ninguém mais disse uma palavra. Então, esta é a lei do autor que não conta com o apoio de determinados meios ideológicos que, sobretudo no Brasil, ainda dominam com uma força extraordinária.

Mediante as estratégias de marketing, os editores costumam procurar manter o caráter elitista, facilitando ou dificultando a possibilidade de editar e a aquisição das obras literárias em virtude das condições impostas aos consumidores, como distribuição e preço. Observemos estas duas citações de um dos ilustradores de vários livros de Amado, ainda nos Anais do III Encontro de Editoração na Bahia (CALASANS NETO, 1993, p. 174): 
Para você chegar as portas de um editor, eu estou falando em termos brasileiros, é difícil, eles querem editar o que tem retorno, nem posso condenar, porque eles estão botando a grana deles. Então é essa a meu ver, a grande luta, atualmente, entre o livro e o público.

Eu acho isso importante e acho que cada dia mais se perde leitores, simplesmente, por culpa dos editores, encarecem a obra, divulgam mal seus livros e, num país continental deste, a distribuição é ineficiente, porque a coisa mais fundamental para uma edição é a sua distribuiç̧ão.

Além disso, as editoras também modificam títulos e expressões quando mantêm os interesses do poder em suas estratégias econômicas, quando ajudam a preservar o discurso hegemônico dos grupos dominantes e quando, por meio da escolha das capas para publicação, interferem na interpretação da obra literária mediante a relação com a ilustração exposta.

Na personalização dos modelos, os editores costumam, também, buscar modelos facilmente identificáveis, mas que só serão publicados se não atrapalhar os interesses da empresa editorial. Observemos a afirmação de mais um ilustrador das obras de Amado:

Ilustrei cinco livros de Jorge, inclusive um, que eu nunca menciono, porque eu ilustrei em Portugal e eu não sei se eles publicaram com as ilustrações ou não, que é "Farda, Fardão e camisola de dormir." Eu desconfio que eles não publicaram com as ilustrações pelo seguinte: porque era justamente naquela época em que o Figueiredo era o presidente do Brasil e eu não sei por que me veio a cabeça aquela história, como a história do Jorge, um negócio assim de generais que pretendem ser acadêmicos de letras, então eu aproveitei e fiz, quase todos os desenhos eram caras conhecidas, era a do Figueiredo, era de não sei quem, os integralistas, com aquela coisa na manga que eles usavam, eu botei a cara do Filinto Muller, botei a cara do próprio Figueiredo e eu tenho a impressão que não publicaram isso, com medo, talvez, eu não sei, nunca vi o livro. (TEIXEIRA, 1993, p. I76-177).

Observa-se, ainda, que a maioria dos editores utiliza parcerias conceituadas e sobrecapas para atrair o consumidor no momento da compra. Essas parcerias e a utilização de sobrecapas funcionam, muitas vezes, como anúncio de oportunidade, em datas comemorativas e/ou chamando atenção, e, ainda, fazendo referência a algo relativo àquela obra, mas que possivelmente deveria estar mais evidente na lembrança do público naquele momento. 
Frequentemente, as editoras contratam críticos para escreverem sobre as obras que irão editar e colocam suas opiniões nas contracapas ou nas orelhas dos livros, para imprimir ao discurso mais autoridade através da voz crítica que destaca, aponta e seleciona, indicando o seu próprio gosto, massificando juízos e opiniões. Na verdade, só se fala do que se conhece, e o discurso crítico, ao ficar entre a obra e o público, é dotado das duas competências básicas: saber ver e saber dizer - e, por meio destas, apresenta ao leitor-leigo as qualidades que identificam o objeto-produto.

A tendência da propaganda e da indústria cultural em massificar o comportamento de consumo, pela distinção de classe e público-alvo, faz o texto crítico oscilar entre o estilo jornalístico e informativo e o estilo crítico, com características específicas de apreciação e julgamento da obra. A crítica, muitas vezes, institui a novidade e a experimentação como critérios de julgamento, em substituição aos tradicionais padrões de beleza e harmonia, e procura estimular no leitor as reflexões, mediante o jogo intrigante do dito e do não-dito no seu discurso.

Como fazer crer, convencer e fazer-fazer, persuadir, não se consegue facilmente nem com rigidez, o autor do texto verbal impresso na capa junta os discursos jornalístico e crítico para que, ao mesmo tempo, informe e produza o argumento de autoridade que seduza o consumidor. Como toda argumentação se desenvolve em função do auditório, segundo Perelmam (1996), a argumentação utiliza técnicas discursivas que permitem provocar ou aumentar a adesão do público-alvo às teses apresentadas. $O$ escritor do texto verbal escolhido pela editora, então, chama a atenção da grande massa, ou seja, de todo e qualquer leitor com o texto jornalístico, e posteriormente faz uma seleção, por meio da argumentação do discurso crítico, com a referência a valores que mais se aproximam daquele público-alvo, obtendo, com isso, a adesão através de persuasão e convicção. É pela argumentação que o capista determina a escolha dos elementos a serem colocados na capa, e o modo de torná-los relevantes. Como as conclusões de uma argumentação também não são restritivas pela própria dialogicidade entre autor e leitor, a importância da argumentação passa a ser não só a seleção de dados, mas igualmente a interpretação e a significação que lhes são atribuídas.

O discurso crítico colocado nas capas pelas editoras, na maioria das vezes, é composto de argumentos estabelecidos em ligações de coexistência, sendo por isso, segundo Perelmam (1996), um argumento de autoridade, evocada pela instituição editorial e pela posição do crítico autorizado pela própria editora como 
capaz para tal enunciação. Este argumento, baseado em ligações que se fundamentam na estrutura "real", normalmente se espelha em exemplos ou modelos e ilustrações. $\bigcirc$ título do romance sempre está sugerindo, a ilustração demonstrando e o texto persuadindo e convencendo o observador-leitor e, uma vez que os acordos iniciais entre capista e o público-alvo ficaram estabelecidos, a argumentação se desenvolve em direção à sua finalidade. Petri (1994), referindo-se às análises aristotélicas sobre a dialética, caracteriza a argumentação como a arte de raciocinar a partir de opiniões geralmente aceitas. Provavelmente, com esses argumentos e afirmações preconcebidos que os autores escreveram o discurso crítico impressos nas capas objeto deste trabalho. Já o leitor-observador do discurso da capa provavelmente aceitará a crítica quando a inserir numa geração, num movimento, numa tendência, e usará essa inserção na contemporaneidade como traço de aceitação. Algumas das afirmações, mesmo quando generalizadoras, não serão contestadas ao se configurarem como retrato de um país ou modismo.

Esse jogo discursivo versa sempre sobre a oposição entre as qualidades internas da obra e o seu valor de mercado, incluindo aí o gosto da época e as exigências do público consumidor. Quando o crítico fala do artista, coloca-o como ser "especial", "estranho" ao comportamento de um cidadão comum, inclusive com o seu trabalho, que é sempre pleno de prazer, como se o próprio repouso fosse uma forma de trabalho e de criação. Na edição brasileira da editora Record ( 1995), a referência a Jorge Amado como irreverente é apresentada ao público por meio de uma foto assinada por sua esposa, Zélia Gattai, numa posição de relaxamento com um pássaro sobre a caneta, escrevendo, como uma figura enigmática, diferente, que trabalha se divertindo. $O$ observador, ao ver essa foto, pode não perceber que houve uma intencionalidade no momento da fotografia e, mesmo que não tenha havido, o olhar da fotógrafa pode ter objetivado isso. Por isso, percebese a presença de uma carga aurática quando se fala de um artista, sempre evidenciando comportamentos que o colocam como engraçado e diferente dos outros profissionais, como disse Teixeira (1993, p. I77) no III Encontro de Editoração na Bahia:

Jorge trabalha muito engraçado, eu não sei se vocês já viram, mas ele trabalha lá na casa dele, tem uma varanda, e ele trabalha ali numa mesinha com uma cesta de comida ao lado. Então, aquela cesta de pão, frutas, porque ele gosta de estar comendo. E nessa época ele tinha um gato chamado Nacib. A função do gato era de peso de papel. O gato era preguiçoso, safado, parecia da família Amado. Ele colocava o 
gato como peso que ficava quietinho ali, ele ia tirando o papel e batendo à máquina. Pois bem, eu ficava olhando. Vi que ele escrevia falando com os personagens. Então, vez por outra o telefone tocava e ele levantava daquela mesa, partia para o telefone, falava e falava, depois voltava para a máquina, depois o telefone tocava de novo. Eu ficava olhando aquilo e um dia perguntei: Jorge, por que não coloca esse telefone lá naquela mesa, está faltando só um telefone ali? Ele disse: "Isso é um aparelho maldito, se eu colocar aqui não vou trabalhar". Era um negócio engraçado.

Assim, o capista, através do seu discurso, reproduz os parâmetros e as exigências do jogo mercadológico, que determina os mecanismos de produção e consumo e até interfere na construção temática e formal da obra.

No discurso crítico, sempre permanece a precariedade nos julgamentos e a fluidez nos critérios de apreciação, fazendo ver que os melhores artistas e os que mais vendem são aqueles bem-sucedidos, diferentes, extravagantes. Há, então, uma opção pela ambiguidade: separa-se a avaliação mercadológica do padrão estético, para em seguida justificar o segundo pelas regras do primeiro. A aceitação de mercados e dos círculos geradores de prestígio passa a ser critério que referenda o valor estético da obra literária. Daí ser tão importante para as editoras mostrar para o público-alvo a aceitação da obra literária no mercado local através da compra, pois este jogo de mercado é tão forte que penetra na substância das obras, tornando-as leis estruturais de valorização do produto. $\bigcirc$ prestígio da venda no circuito cultural torna-se elemento definidor do seu valor, assegura ao artista um lugar de destaque, sua indicação ao leitor e a segurança no investimento. É assim que um bom produto pode superar uma boa obra de arte. $\mathrm{O}$ crítico, então, utiliza-se do seu discurso para orientar a leitura do observador leigo, oferecendo-lhe um olhar esclarecido e mais atento por estar ciente do seu papel formador de opinião. E comprova suas afirmações, por meio de dados estatísticos das vendas do produto, para que o leitor assimile o discurso crítico e se sinta competente para investir na compra do livro, sem se dar conta da consciência ideológica do sujeito que constituiu o texto da capa.

Ainda analisando o discurso verbal impresso pelas editoras em capas de livros, observa-se, também, a seleção de algumas palavras, silenciando outras, que apontam para alguns implícitos. A crítica é uma forma de censurar, não tanto pelo que informa, mas pelo que deixa de dizer, e o critério de escolha se configura em dizer isto e não aquilo, de forma a direcionar a compreensão do leitor para a compreensão desejada pelo locutor. 
Quanto ao discurso não-verbal, a posição dos editores e capistas na escolha da ilustração ou do ilustrador é também, às vezes, muito difícil pela falta de características detalhadas dos personagens, na obra literária, como relata Floriano Teixeira (1993, p. 174):

Por exemplo, Gabriela. Eu já vi Gabriela de todo jeito, até eu já fiz uma Gabriela. E eu perguntei para ele [Amado] como era a Gabriela fisicamente. Porque tinha a Sônia Braga, tinha as Gabrielas de Di Cavalcanti. "Olha, Gabriela não é isso que as pessoas fazem por aí. Gabriela é uma mulata de cabelo duro, mas ela é dengosa, é roliça." Toda mulher de Jorge é roliça porque parece gordura, coisa assim de comer.(risos). Então, ele disse: "ela tem todas as características do mulato cabo verde, que é esse mulato bonito do nariz afilado, cabelo meio liso ondulado." Então, muitas das vezes você tem que adivinhar como é aquela figura, como foi o caso de Dona Flor, como foi o caso de outros livros que eu ilustrei com Jorge. Você tem que adivinhar. Ele não diz como o personagem é fisicamente.

Então, quando a própria obra literária não define o personagem com detaIhes, o modelo da ilustração passa a ser a única referência e, portanto, maior será o poder de relação das representações nas capas ou ilustrações internas do texto literário.

Na rapidez em que se dá o consumo, o público não tem tempo de questionar e a maioria das pessoas não analisa as regras sociais que deram origem a determinados produtos. Não procuram descobrir os vestígios e marcas do sistema produtor que o engendrou, já que estes permanecem "invisíveis" superficialmente, mas latentes para quem os analisa. As informações passadas ao público pelas embalagens não revelam explicitamente o que está por trás desse discurso. Na maioria das vezes, servem para ocultar o que representam, ou para intermediar, nem sempre abreviando o caminho entre emissor e receptor, mas apenas evidenciando qualidades que são do interesse do editor.

Interessados em divulgar os pontos de vista políticos e sociais dos seus respectivos países, as instituições editoriais provocam inúmeras distorções, chegando a ponto de modificar características incomparáveis de alguns personagens, como afirma Teixeira (1993, p.|80-181):

Era a capa do livro que eu tinha feito com um quadro, porque aquilo ia ser exposto na Bienal do Livro em São Paulo. Então Alfredo Machado (editor) trouxe aquilo e disse: "Você fez um negócio desse e não pode. Eu não vou colocar uma velha na capa do livro." Eu disse que foi o Jorge quem me pediu para colocar essa velha. Ele disse: 
"Jorge não entende de livro, rapaz, quem entende de livro sou eu. Coloque uma mulher nova, bonita, porque mulher nova é que vende livro." Então, eu fui fazer uma mulher nova.

Por outro lado, a leitura é apropriação e produção de significados, e a dialogicidade entre autor e leitor permite que o leitor subverta aquilo que o livro pretende impor. Será que os leitores estão cercados de limitações, derivadas de convenções e hábitos de leituras, como também de estratégias armadas pela elaboração das comunicações de massa que hoje fazem parte da elaboração do livro? Será que existe uma censura sutil, funcionando mediante o silêncio de algumas informações, da negação do que é considerado impróprio, ilegível, irreconhecível, do uso das coenunciações nas traduções, das imposições canônicas, dos cortes e modificações de texto, do uso das metáforas, dos estereótipos e da revitalização dos mitos, na busca de uma harmonia entre texto literário, modelo e público-alvo?

\section{o Contraste e a Censura}

Quando o capista se preocupa com a harmonia na criação, automaticamente está atento aos contrastes, já que se trata da oposição entre as cores, fazendo uma sobressair à outra. Acontece uma diferença acentuada, principalmente quando se colocam cores complementares lado a lado. $\bigcirc$ uso de muito contraste causa geralmente a sensação de impacto ao observador e exibe modificações de valor do tom, chegando, às vezes, a confundir a percepção nítida dessas cores pelo observador. Essa sensação de mistura de tons e de perda da nitidez, pela intensidade do contraste, muitas vezes não é percebida por quem olha, devido à ação recíproca de uma cor sobre a outra, provocando, às vezes, indução de uma nova cor devido à saturação das células responsáveis pela absorção das cores no globo ocular humano.

Esse grande contraste ou oposição pode não apenas acontecer na utilização das cores, mas também na utilização dos signos devido a algumas estratégias impostas ao capista pela editora, resultando em sérias modificações no seu trabalho e, consequentemente, na relação entre capa e obra literária.

A sociedade, devido à rapidez do consumo, não percebe a finalidade do discurso publicitário em travestir os conteúdos dos desejos do consumidor para 
que não sejam reconhecíveis pela consciência. Sabe-se que os procedimentos de deformação usados pela censura são deslocamentos, condensação, omissão e transformação de uma representação em seu contrário. Nas capas, esses procedimentos são manifestados e a análise desses processos de simbolização é importante no estudo da cultura. A cultura é uma construção histórica, um produto coletivo no qual a mudança é um aspecto fundamental. Através da história da cultura, desenvolve-se um universo de legitimações. Os estudos culturais procuram entender o sentido dessas representações, concepções práticas para a sociedade que as vivenciam. Os meios de comunicação propõem estilos de vida, modos de organizar, vestir, decorar, escrever, falar, sonhar, sofrer, amar, lutar e, principalmente, pensar e simbolizar o real.

A forma de se dirigir a cada receptor parece individualizada, mas na verdade as mensagens são comuns a todos, pois são elaboradas procurando sempre a homogeneização e o amaciamento dos conflitos sociais. Estabelece-se uma contradição entre exigências produtivas, técnicas de estandardização e o caráter individualizado e inovador necessário ao consumo da indústria cultural. Os modelos-guias, as formas arquetípicas do imaginário, os temas míticos, os personagens-tipos constituem uma estrutura interna constante que a indústria cultural utiliza.

Se algumas capas estrangeiras mostram em suas ilustrações novos modelos da personagem Gabriela que funcionam para os seus públicos-alvo como um signo autônomo e singular, que não é a representação da mulata brasileira nem de uma mulher do país que originou a capa, esta representação torna-se um signo intervalar. Esse "novo" signo funcionará como um interstício cultural originado de uma necessidade de representação situacional para comunicação e posterior consumo do livro.

O consumo dos produtos é, ao mesmo tempo, autoconsumo da vida individual e autorrealização, por isso o desenvolvimento industrial cria sempre novas condições de vida para fazer emergir novas necessidades individuais. Esse consumo torna irreal uma parte da vida dos consumidores, mediante a projeção de universos imaginários em duas direções diversas: distraem, enganam e consolam com a fantasia e, ao mesmo tempo, impelem a imitar os novos modelos para a procura da felicidade. Sendo assim, as capas desempenham uma função importante, na medida em que agem como elementos ativos dessas estruturas. Isso acontece porque suas representações se adaptam continuamente às pressões, às contradições que emergem da sociedade, englobando-se e integrando-se ao próprio sistema cultural. 
Nessa perspectiva, foram investigados as funções sociais e os efeitos das capas dos livros de Gabriela, Cravo e Canela, o modo como são articuladas dentro da relação comunicativa e o mecanismo de reconhecimento e de atribuição do sentido, parte essencial nessa relação. Partindo dessas observações, foram analisadas as convenções de linguagem que assumem o lugar de "verdade", nos termos da adequação da coisa a sua representação, forçando leitores e observadores a procederem de acordo com a rígida seleção de regras, modelos e formas simbólicas que sustentam a identidade do objeto, do sujeito e do outro, tentando o apagamento da dinâmica natural de reconhecimento. Não estaria acontecendo um processo de censura ao tentar impedir o interlocutor de sustentar outro discurso?

Lembrando da construção do pensamento do povo brasileiro ao longo da sua formação e das várias influências sofridas, tendo em vista as situações históricas, políticas e culturais, sabe-se que larga faixa do pensamento brasileiro foi produzida dentro de uma visão eurocêntrica, resultando numa relação Ocidente/ não-Ocidente como exótica e sempre com uma imagem negativa do outro nãoocidental. Considera-se, então, de acordo com Said (1995, p.245):

[... ] 'Ocidente' e os 'outros' culturais por ele dominados não se restringem uma forma de entender um relacionamento desigual entre interlocutores desiguais, mas constitui uma porta de acesso para o estudo da formação e do significado das próprias práticas culturais ocidentais. Eteremos de levar em conta a persistente disparidade de poder entre o Ocidente e o não-Ocidente, se quisermos entender bem formas culturais como o romance, o discurso etnográfico e histórico, certos tipos de poesia e ópera, formas nas quais abundam alusões a essa disparidade e estruturas nelas baseadas.

Como o objeto de investigação deste trabalho são discursos que dialogam com uma obra literária que fala da Bahia-Brasil, decidiu-se averiguar se nas capas aparecem marcas desse discurso ocidental, passado através do tempo, e se interferem reforçando e familiarizando formas estereotipada de pensamento. Sabe-se que países colonizados como o Brasil não são representados realisticamente, perpetuando um processo anedotal e ficcionista devido aos poderes de relação. As generalizações, que colocam os indivíduos colonizados como uma massa indistinta e estereotipada, continuam sendo acreditadas e representadas num período atemporal, repercutindo numa paródia, com descrições que passam a ser divertidas. Assim, alguns capistas estrangeiros, ao representarem a mulata brasileira descrita por Amado na personagem Gabriela, podem estar utilizando esse imaginário, projetando-o em cópias malfeitas, imagens avessas, rebeldes, retratando-a com 
julgamentos preestabelecidos, transformando-a em clichês, generalizações e apreciações estereotipadas, e até em simulacros por meio de um processo de censura.

O simulacro como representação na relação Ocidente/não-Ocidente é usado, na maioria das vezes, como imagem sem semelhança. Contesta tanto a noção de modelo como a de cópia, já que é um simulacro originado de um fantasma, formado com dados que reforçam os paradigmas dos europeus e que, ao mesmo tempo, demonstram a sua forma de apropriação. Trata-se de uma representação do outro que se transforma e deforma de acordo com o ponto de vista do seu criador. Essa dessemelhança pode acontecer devido às grandes distâncias que 0 observador que o constrói não consegue dominar. E, exatamente porque não as domina, experimenta essa expressão desigual como semelhança. Essa dissimilitude, o tempo que ilude e as generalizações sempre em terceira pessoa, assumidas como padrão global na comunicação, contribuem para dificultar a observação da sociedade. Funciona sempre o imaginário ou o conhecimento adquirido pelo discurso fundador sobre o Brasil e instituído no país de origem do observador estrangeiro. Por isso, nas representações, os estereótipos fazem parte dessa estratégia discursiva, produzindo uma simplificação e um efeito de verdade. Bhabha (1998, p. I I0), refletindo sobre esse assunto, observa:

O que é, portanto, uma simplificação no processo da representação estereotípica tem um efeito de colisão sobre o seu foco central de abordagem da política do ponto-de-vista. Eles operam com uma noção passiva e unitária de sutura que simplifica a política e a estética do posicionamento do espectador, ao ignorar o processo ambivalente, psíquico, de identificação que é crucial ao argumento.

A possibilidade de reconhecimento das características do povo brasileiro por meio das ilustrações das capas pode perder-se nas generalizações, e simplificações, impedindo que o observador inicie um processo de identificação através do signo.

$\mathrm{Se}$, no momento da comunicação, o signo opera sempre numa estrutura de repetição, para que possa ser reeditado e reconhecido, produz sempre uma representação de uma apresentação já feita naquele ambiente cultural em outro momento passado. Essa representação como forma de pensar e de ver alguém, o "olhar estereotipado", apaga as singularidades da visão e observação peculiares do indivíduo, endossa os discursos preconceituosos, discriminatórios, moralistas, estrategicamente construídos para a dominação e para uma evidente superioridade que impedem a demonstração das formas singulares da interdição e de uma censura velada. 
Esse sistema de representação, utilizado como verdade, está presente nas capas do livro Gabriela, Cravo e Canela, demonstrando um Orientalismo que está latente e manifesto, porque funciona como repositório inconsciente da fantasia, polarizando sempre poder e saber. $O$ valor histórico do texto amadiano, nesse livro que descreve e faz conhecer particularidades do povo baiano, pode estar sendo modificado, porque não permite revelar as singularidades, visto que os modelos são os do paradigma discursivo do conhecimento da Bahia-Brasil que circula na sociedade do país responsável pela editoração. Instala-se a multiplicidade do olhar, ou seja, as diferentes interpretações. $O$ texto modificado pelas traduções e interpretações metafóricas, usadas nas ilustrações das capas, poderão contribuir para a manutenção da imagem da Bahia, do Brasil e do povo brasileiro que o leitor estrangeiro já conhecia, dificultando a percepção do "olhar" de Amado.

Na perícia de construção e recepção dessas interpretações metafóricas usadas como ilustrações, os significados não são atribuídos adequadamente ao contexto e o mais perigoso é que, possivelmente, essas metáforas podem ser explicadas e entendidas pelo público-alvo por outras metáforas.

Como as metáforas são importantes na construção do mundo conceitual, no processo cognitivo do outro e na formação de significados, são por demais utilizadas, e pouco são os usuários que param para refletir sobre sua origem. Conduzem o pensamento do sujeito leitor por meio de conceitos falsos de analogia e similaridade. $O$ capista pode misturar um referente extraído do texto amadiano a um referente extraído do seu imaginário como intérprete. $\bigcirc$ uso das metáforas e dos estereótipos pode vir carregado de segundas intenções que impedem a circulação e a articulação de significantes, que resultam na problemática ver e ser visto.

Quando as representações sociais que nos foram transmitidas, são apenas reproduzidas, são mantidas as relações sociais necessárias para a manutenção das relações de produção da vida material em sociedade. Por isso, o discurso colonial é tão assimilado pelo discurso propagandístico e torna-se um repertório de posições conflituosas, fornecendo uma identidade encenada e fantasmática. Os textos brasileiros considerados por alguns como homogêneos tornam-se conflituosos diante das relações de poder, porque cada texto feito reforça uma imagem estereotipada de pensamento deixada pela colonização. As sutilezas provenientes da nossa cultura híbrida, presentes nos textos de Amado, não podem ser facilmente perceptíveis por estrangeiros, que convivem com uma cultura completamente diversa. Sendo assim, as generalizações radicais passam a dominar, o conhecido e 
3 É evidente que, quando falamos em metáfora aqui no texto, aplica-se por extensão aos outros topos fundamentais que são a metonímia, a sinédoque e a ironia, como também estão incluídas as três possibilidades de tradução: a tradução de uma metáfora pela mesma, por uma diferente e por uma não-metáfora. o pré-construído serão repetidos dada a incapacidade do estrangeiro de lidar com a diferença, dando lugar às metáforas que passam a simbolizar o social, para assegurar um ponto de identificação e, conseqüentemente, essas metáforas só serão possíveis de serem identificadas com precisão entre parceiros de um mesmo grupo cultural, através de um "saber compartilhado" (PAIVA, 1998, p. 124).

Na elaboração das capas, os capistas não têm consciência do grau de especificidade das metaforizações que estão trabalhando e as conseqüências dos implícitos contidos nessas figuras de linguagem na comunicação com o público-alvo. Caso seja uma metáfora ${ }^{3}$ latente, uma imagem temática e consagrada pelo uso, provavelmente não haverá problemas na repetição do símbolo ou tradução ipsis litteris, mas tratando-se de uma metáfora viva, o capista deverá considerar com muito cuidado o sentido primário daquela imagem ou expressão na cultura do escritor da obra literária, para que o sentido não seja modificado. Em geral, há um jogo associativo entre objeto e imagem, sem relação com o posicionamento étnico-cultural da imagem descrita pelo escritor.

As singularidades do texto amadiano, consequentes dessa população colonizada e híbrida, são resultantes desse conjunto "pulsante e interconectado" que é a cultura brasileira. Será difícil, portanto, para o estrangeiro perceber o branqueamento de algumas raças, o apagamento de marcas populares através do discurso disciplinador da história, e as "sub-raças" resultantes da sobrevivência de uma cultura hegemônica. No espaço entre a dominação e a subordinação, também será difícil perceber a resistência das culturas dominadas, da periferia com relação ao centro, e as presentes dicotomias entre tradicional e moderno, urbano e rural, erudito e popular, hegemônico e subalterno, presentes no Brasil.

Talvez por tudo isso, as Gabrielas representadas em algumas edições estrangeiras sejam apresentadas brancas, com cabelos lisos, substituindo a mulata do texto amadiano, provavelmente pela dificuldade de percepção, por preconceito ou para que haja um reconhecimento e uma identificação com o público-alvo. Homi Bhabha (1998, p. III), nesse sentido, observa:

[... o discurso colonial produz o colonizado como uma realidade social que é ao mesmo tempo um "outro" e ainda assim inteiramente apreensível e visível. Ele lembra uma forma de narrativa pela qual a produtividade e a circulação de sujeitos e signos estão agregadas em uma totalidade reformada e reconhecível. Ele emprega um sistema de representação, um regime de verdade, que é estruturalmente similar ao realismo. E é com o fim de intervir no interior desse sistema de representação que 
Edward Said propõe uma semiótica do poder "orientalista.", examinando os diversos discursos europeus que constituem "o Oriente" como uma zona do mundo unificada em termos raciais, geográficos, políticos, e culturais.

Então, para o reconhecimento dos seus modelos, o capista está sempre reformando e adaptando-os ao público-alvo, deixando subentendido que o que está no lugar conhecido é que deverá ser repetido, também para manter a oposição entre pureza e mistura racial numa relação político-discursiva.

Não se pode deixar de registrar a presença do fetichismo como recusa da diferença, pelo uso da metáfora como representação e da metonímia como substituição da ausência, da falta, como uma parte que substitui o todo, a sombra, como recusa e defesa de não querer reconhecer o outro. Se o fetiche é o objeto ao qual são atribuídas propriedades mágicas, especiais ou sobrenaturais, no momento em que um capista estrangeiro nega o reconhecimento e a representação do outro, mulato brasileiro, torna esse outro uma fantasia, um fetiche, porque sabe que existe, mas nega a sua presença e representa-o com um tipo físico semelhante ao seu. Desta forma, a representação dessemelhante passa a ser a sombra da representação negada através de um efeito metonímico. Bhabha (1998) justifica essas atitudes através dos comportamentos psicanalíticos, citando a psicopatologia do reconhecimento da diferença, na qual o sujeito perde a ilusão da completude e se transforma no sujeito do desejo. Dentro desse princípio, o fetiche representa um jogo simultâneo da ausência, da diferença e da falta percebida, uma crença contraditória como reconhecimento e recusa. O reconhecer e recusar pode ser um ato de censura.

O fetiche ${ }^{4}$ é testemunho de que a realidade foi constatada, embora recusa$\mathrm{da}$, e surge como uma forma de desligar o eu da realidade e dissimula tornandose, às vezes, mais importante que a própria realidade.

Já o desejo surge da imaginação e são os efeitos metonímicos ligados à linguagem que instituem o objeto do desejo. Este dá sentido à vida do consumidor, surgindo da defasagem entre a necessidade e a demanda. Apresenta-se como uma forma de desligar o eu da realidade e nasce da imaginação, ligando o real ao simbólico. Se o simbólico, na comunicação propagandística, consegue inscrever o desejo no inconsciente e se o significante pode exprimi-lo é porque o símbolo rege o mundo das propagandas. O simbólico, na propaganda, organiza de forma subjacente as formas predominantes do imaginário, por meio de efeitos como

\footnotetext{
4 Segundo Bhabha (1998, p. I 16): "No discurso o fetiche representará um jogo simultâneo entre a metáfora como substituição (mascarando a ausência e a diferença) e a metonímia (que registra contiguamente a falta percebida)"
} 
A propaganda sempre procura utilizar dos pressupostos da teoria psicanalítica, quando incentiva o hábito de consumo das pessoas, levando-as a serem exploradas de forma inconsciente pelos mecanismos enganadorese manipulativos da linguagem, como confirmam Santana Neto e Caldas (1994, p.449):

"O consumidor conserva uma aparência de árbitro mas está condenado a responder a estímulos cujos mecanismos, muitas vezes, não lhe são claros, justamente por que a linguagem que 0 comanda atingiu requintes de extrema sutileza"

${ }^{6}$ No momento em que a propaganda compensa a monotonia da vida cotidiana pelo emprego da fantasia, não faz mais do que mostrar às pessoas como elas podem vir a ser o que elas não são. Santana Neto e Caldas (1994. p.452) dizem que, quando somos receptores da comunicação, acontece "[...] a oposição do que somos e do que gostaríamos de ser não mais existe e o receptor assume o sonho. Sonho esse que passa a ser realizável pelo poder de compra e o amor próprio retirado pela publicidade é devolvido no ato de compra". competição, agressão ou sedução, e o consumidor acede a essa ordem simbólica por intermédio de operações e negações ${ }^{5}$. Se a linguagem é o simbólico e o sujeito existe na linguagem, a negação de um símbolo existente na linguagem torna-se uma defesa do ego.

O discurso propagandístico inicia substituindo o indivíduo por um indivíduofetiche (fantasia) que é a massa, através da sua homogeneização, e, como o objetivo é tornar essas pessoas iguais aos produtos que consomem, as relações humanas que antecedem as mercadorias desaparecem no ato da troca mercantil. Estas alimentam a fantasia, levando o consumidor a um futuro continuamente adiado, mas insistindo sempre numa ponte que liga o sonho à realidade. No momento em que a propaganda compensa a monotonia da vida diária do consumidor, estes produtos novamente se tornam fetiches ${ }^{6}$.

Quando o capista, consciente de que seu trabalho deverá, em parte, assegurar a venda do livro, coloca a imagem de uma mulher sedutora, atraente e bonita, representando a Gabriela, poderá estar pressupondo que as leitoras-observadoras se sentirão atraídas pelo livro que fala sobre a história de uma mulher cujas características gostariam de ter, e os homens, por um tipo ideal de mulher que também gostariam de ter.

Vale registrar que as capas, como propaganda, trabalham as atitudes sociais dominantes e revitalizam os mitos antigos. Ao observá-las, pode-se medir a temperatura ideológica do momento. A ideologia das pessoas equivale aos valores e práticas sociais assumidos, que pertencem ao domínio do senso comum e permitem alcançar a essência do que é visível para todos. $\bigcirc$ mito, ao se repetir em diferentes contextos, produz múltiplos sentidos, pois não há sentidos eternos, mas sentidos eternizados. Ao se observar o mito, pode-se perceber a eficácia e o valor social desse tipo de narrativa, a partir da qual a sociedade se expressa, indica seus caminhos, discute consigo mesma. Segundo Lévi Strauss (1955, p.52): "[...] o valor do mito como mito persiste a despeito da pior tradução", por conseguinte, a tradução tem validade zero no caso do mito. Exatamente porque este não possui sólidos alicerces de definições, ele flutua, seu registro é o imaginário e sua possibilidade intelectual é o prazer da interpretação. Como a interpretação é incerta, pois depende da experiência do intérprete, o mito passa a ser construído de acordo com os interesses ${ }^{7}$.

Tanto o discurso literário como o artístico e o propagandístico se utilizam do mito para dar sentido a suas afirmações, recorrendo ao já-dito, para produzir a impressão de que o sentido só pode ser um. 
Finalmente, é importante registrar que o jogo estratégico das capas não passa de um mero ritual de legitimação, pois são apresentadas à população permeadas de juízo de valor, normas a serem seguidas, insinuações ou mesmo orientações diretas de como as coisas devem ser, o que é bom ou ruim, o que pode e não pode ser feito, levando o público a agir de acordo com os valores desejados pela ideologia dominante, pelo discurso competente que, ao mesmo tempo, "informa", controla e manipula mediante um processo silencioso e contínuo ${ }^{8}$. Algumas metáforas, estereótipos, mitos, arquétipos e fetiches presentes nos discursos das capas podem estar sendo usados como uma censura velada, que reconhece e identifica a realidade social, mas não se compromete, negando-a em suas representações.

Sabendo que cada realidade cultural possui sua lógica interna e considerando as relações entre essas culturas, serão observadas, através dos discursos de cada capa, as representações escolhidas para cada realidade cultural, para perceber como estas se relacionam e como funcionam, e quais os sentidos que, ao se perpetuarem, vêm hierarquizando os povos, as nações. Com essa percepção, serão analisados em seguida, os efeitos da colonização, apagamentos, estranhamentos e cristalizações que podem estar presentes, até hoje, na cultura brasileira. 


\section{as Cores Originais e as Capas Brasileiras}

... escrevo em baianês, língua decente, afro-latina...

Jorge Amado

" Cada palavra evoca um contexto ou contextos, nos quais ela viveu sua vida socialmente tensa: todas as palavras e formas são povoadas de intenções..."

Mikhail Bakhtin 


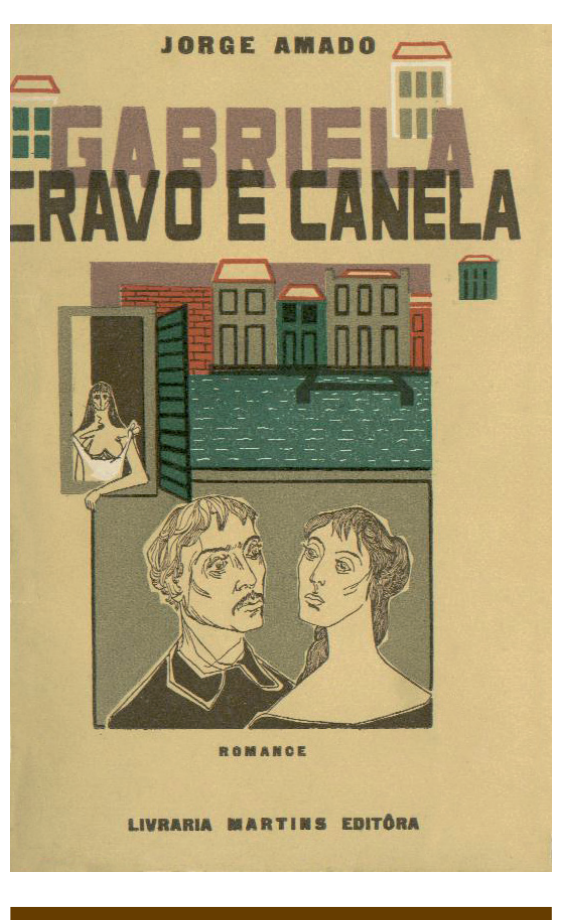

\section{Primeira Capa}

Título Gabriela, Cravo e Canela

País BRASIL

Editora Livraria Martins Editora

Ano 1958

Autoria da capa Sem Referência

Autoria da ilustração Clóvis Graciano

Técnica da ilustração XILOGRAVura 
As primeiras pinturas feitas pelo homem estão registradas nas rochas das cavernas, e os pigmentos para imprimir essas pinturas rupestres foram retirados da natureza e muitos deles da terra. Esses pigmentos locais e duradouros refletem a sua origem e demonstram a cor do local e do tempo no qual a pintura foi executada. Pinturas feitas com pigmentos retirados da terra, do local onde estarão sendo feitas, dão ao observador a sensação de fidelidade. Hoje, devido à origem, a expressão tons terrosos é usada, também, para as cores que se assemelham às cores de terra do tipo: marrons, ocres, vermelho escuro, preto e outros. Mas, para compreender a história de uma representação pictórica, não se pode deixar de observar de onde vieram os pigmentos usados, para contextualizá-las. Assim, foram relacionados os tons terrosos, que demonstram a origem de uma pintura, como "pistas" para contextualizar o discurso.

Nesse sentido, é essencial observar a origem não só dos pigmentos, como a situação no momento de cada criação, para entendê-las. Partindo desta premissa, serão observadas, as condições de produção, as formas e tonalidades dadas pelos capistas brasileiros, cuja origem é semelhante à de Amado, na representação do romance Gabriela, Cravo e Canela.

Identificado o lugar onde foi publicada a capa, o passo seguinte foi delinear o contexto de cada edição para uma aproximação do significado das representações usadas.

Quanto aos pigmentos terrosos e ao contexto da época, percebe-se que o Brasil, país de origem de Amado, possui a maior extensão na América Latina, tem 
a língua portuguesa como língua oficial, e o seu povo tem como religião dominante a Católica Romana e, em menor quantidade, protestantes com várias denominações, além da prática de muitos cultos de origem africana. Essas religiões se misturam devido à história da colonização do seu povo, principalmente em algumas regiões em que há grande participação de negros trazidos da África, na época da escravidão. Também integram a população brasileira, imigrantes europeus transferidos para o Brasil por fluxos migratórios internacionais, desde o começo da colonização, e que se juntaram aos índios, habitantes autóctones do lugar.

Um dos fatores que também contribuiu para a emigração de alguns estrangeiros que vieram a se estabelecer no Brasil, em séculos mais recentes, foram as violentas guerras que atingiram alguns países, motivando muitas famílias a reconstituir suas vidas no Brasil. A união das várias etnias, principalmente as consideradas raças branca, negra e indígena, fez da população brasileira um povo mestiço no tipo biológico, com características peculiares, em que a mistura de culturas muito diferentes teceram a cultura brasileira, híbrida e singular.

Segundo o censo de 1999, o maior conglomerado de pessoas, no Brasil, se encontrava na Cidade de São Paulo, e a população brasileira era de, aproximadamente, 169,6 milhões de habitantes, com 54\% de brancos, 39,9\% de pardos, $5,4 \%$ de negros, $0,5 \%$ de amarelos e $0,2 \%$ de indígenas. É importante salientar que, devido ao preconceito racial, ficou registrado, nesse censo, que muitos negros, ou seus descendentes, davam diferentes denominações para o seu tipo racial, considerando a cor da pele. Segundo alguns autores, um registro de mais de I 00 denominações foi grafado para o mestiço ou para os tipos étnicos resultantes da mistura de negro e índio ou negro e branco.

Outro dado merece ser considerado, a modernização do País que, após a década de trinta, foi consolidado um polo industrial no Sudeste, abrindo novas fronteiras agrícolas nas Regiões Centro-Oeste e Norte. A partir de 1945, houve uma rápida industrialização, que tornou o Sudeste um importante centro manufatureiro. Apesar da industrialização e uma sequência de planos econômicos, o País continua, até hoje, com renda per capita baixa em relação aos países chamados de "primeiro mundo", persistindo a marca das desigualdades sociais e do analfabetismo. Ocupa a $69^{\mathrm{a}}$ posição no ranking mundial quanto à qualidade de vida.

A Bahia, local onde se passa a história de Gabriela e onde nasceu Amado, é o mais populoso dos Estados da Região Nordeste, com extensa faixa litorânea, clima tropical e um contingente significativo de negros. Possui regiões com características 
bem diferentes, chegando alguns autores a afirmar que existem várias "Bahias". A história oficial do Brasil informa que os primeiros estrangeiros que chegaram ao País aportaram na Bahia, por isso foi uma das regiões de grande atração populacional, mas, com o colapso da agricultura açucareira, passou por uma estagnação econômica que gerou pobreza e analfabetismo.

Salvador, capital do Estado e primeira capital do Brasil, tem grande parte da sua arquitetura marcada por construções do período colonial, com muitas igrejas, ruas estreitas e ladeiras íngremes. Segundo muitos autores, Salvador possui a comida mais mestiça do Brasil, com a mistura de ingredientes africanos, indígenas, europeus e intervenções do Médio e Extremo Oriente. As marcas da ancestralidade sobressaem tanto na culinária quanto na música. Além disso, a Bahia possui, na sua história, uma velha classe dominante, "os coronéis do sertão", também descritos por Amado no romance.

É bom lembrar que, na agricultura da Bahia, existem três áreas que se apresentam prósperas, e o sul do Estado é uma delas. Por longo período, concentrou uma série de empreendimentos devido ao plantio do cacau. As características dessa região, no início do crescimento, são descritas por Amado no romance Gabriela.

A capa da primeira edição de Gabriela Cravo e Canela, em 1958, é de autoria de Clóvis Graciano. As influências do contexto em que se insere o autor são de suma importância para "[...] a avaliação dos fatores pragmáticos do ato da produção discursiva, ou seja, avaliação da instância verbal da produção do discurso como: situacionalidade, intencionalidade, aceitabilidade, intertextualidade e informatividade", segundo Sitya (1995, p.77). Assim, procurou-se investigar a situação social na época da produção da capa, através das notícias jornalísticas, nacionais e internacionais, especialmente no período de lançamento de cada edição.

Os destaques jornalísticos no Brasil, em 1958, informavam que os governantes faziam muitos planos para a mudança da sede do governo e capital do País, do Rio de Janeiro para a nova capital no Planalto Central brasileiro e que se chamaria Brasília. Havia um novo caminho para o progresso. Já se comentava sobre a entrada da indústria automobilística no Brasil e a tentativa de utilização da mãode-obra nacional aliada ao capital estrangeiro. A imprensa noticiava que o presidente J. Kubitschek, em plena gestão, estava recriando o Brasil. Todo esse desenvolvimento trazia novidades importantes para a cultura urbana brasileira, como a arquitetura de Lúcio Costa e Niemeyer, o novo ritmo musical, a Bossa 
Nova, e a criação do Cinema Novo, movimentos que, apesar da apropriação de técnicas estrangeiras, voltavam-se para as raízes nacionais. O povo brasileiro olhava para suas necessidades, a meta era construir em cinco anos o que deveria ter sido feito em 50. O lema era 5 por 50 ou 50 anos em 5. Nesse mesmo ano, foi lançada outra obra de Amado pela produtora Festa Discos do Rio de Janeiro, o disco Canto de Amor à Bahia e Quatro Acalantos de Gabriela, Cravo e Canela, com locução do próprio Jorge Amado e música de Dorival Caymmi. O disco obteve grande sucesso de público, chegando à sexta edição e ultrapassando a venda de cinqüenta mil exemplares em um ano.

As manchetes internacionais relatavam as tensões no Oriente Médio por causa da guerra fria e destacavam que o mundo árabe tentava unificar-se, defendendo-se contra o Ocidente, Israel e os governantes conservadores. Esse movimento pan-árabe que, nos anos 50/60, tentava unificar o mundo árabe contra Israel e o domínio ocidental, tinha como líder o presidente egípcio G. A. Nasser, que havia desafiado o Ocidente ao nacionalizar o Canal de Suez. Ele apoiava todos os movimentos que lutavam contra o domínio branco na África. A luta era contra a nobreza conservadora, e a Casa Branca via o nacionalismo árabe como caminho para o comunismo.

Como se pode observar nessa breve síntese, os enfoques jornalísticos demonstravam o clima de mudança que acontecia no contexto político, social e econômico na época de lançamento do livro. Era muito semelhante ao que Amado trazia para a ficção: os árabes em evidência internacional, a luta contra o conservadorismo e opressores e a utilização da mão-de-obra nacional eram temas das grandes discussões do momento. Esse romance amadiano e sua capa estavam inseridos nessas discussões ao narrar a história de um árabe envolvido com uma brasileira imigrante tangida pela seca, personagens participantes de um cenário desenhado pelo poder opressor dos coronéis, que sinalizava para a necessidade de mudanças para que o progresso se instalasse.

As representações impressas nas capas das várias edições também vão deixar pistas da época em que foram realizadas, pois aglutinam características do contexto social do ilustrador e do momento da criação, tais como: tendência ilustrativas, preferência de cores, tipos de pigmentos e outros.

Todo pigmento para ser utilizado e fixado, num suporte qualquer, necessita de um meio aglutinante, que junte, reúna, cole e fixe para que apareça a cor. São vários os aglutinadores usados para aplicação das cores: óleo, gema de ovo, goma, 
Expressionista adepto ou seguidor do expressionismo, que é uma técnica de pintura, desenho e escultura, surgida no início do século $X X$, que tende a deformar ou a exagerar a realidade por meios que expressam os sentimentos e a percepção de maneira intensa e direta (FERREIRA, 1975, p. 600). resina e outros. $\bigcirc$ meio aglutinador é que vai dar a solidificação ao pigmento. As receitas para a produção das tintas são, hoje, numerosas, variando bastante o tipo de aglutinador, mas o meio de aglutinação das cores pode ser também escoIhido pelo artista, de acordo com o objetivo do trabalho, já que o tipo do meio aglutinante pode modificar o resultado das cores.

A função do meio aglutinante pode ser comparada com o papel do capista e do ilustrador, quando une os pigmentos, mistura as tintas, escolhe e mistura as formas para representar seu pensamento na capa. Fazem parte do trabalho do capista a seleção dos elementos que irá imprimir na capa, a aglutinação desses elementos de acordo com o objetivo da sua informação, semelhante ao ilustrador na escolha dos signos para representar o seu pensamento na ilustração. $\bigcirc$ conhecimento de quem é o ilustrador da capa é indispensável, pois pode facilitar o entendimento das escolhas dos signos para representar a obra literária.

Como não há indicação de autoria da maioria das capas analisadas neste trabalho e como a ilustração escolhida normalmente é a que mais demonstra o sentido da capa, a imagem ilustrativa será sempre o principal alvo de reflexões.

A ilustração escolhida pelo capista para a primeira capa desse romance de Amado é de autoria de Clóvis Graciano. Seu perfil poderá contribuir para a análise do seu foco de escolhas e seleções. Paulista da cidade de Araras, ele nasceu em 1907. Estudou no curso livre de Desenho da Escola Paulista de Belas Artes e tornou-se adepto do figurativismo expressionista', tendo como modelos Portinari, pintores do Cubismo e muralistas mexicanos. Seu trabalho tem como característica a linearidade e a expressão do movimento. Dedicou-se a pinturas murais e à ilustração de obras literárias. Os temas mais utilizados em seus quadros são meninos com passarinhos e dançarinos, somente alguns poucos revelam um estilo dramático, como o Auto-Retrato. Graciano fazia parte do grupo Santa Helena, formado por artistas amadores que, em meados dos anos trinta, reuniam-se para desenhar e trocar idéias sobre artes. Em 1937, participou do ${ }^{\circ}$ Salão da Família Artística Paulista, fazendo parte do grupo de artistas que se destacou pelo senso de equilíbrio, dado o respeito aos conhecimentos técnicos acadêmicos e às diferentes formas de representação. Esses artistas diziam estar libertos dos preconceitos do Modernismo. Esse grupo ficou registrado como exemplo vivo da chamada "pintura nova" de São Paulo.

Como qualquer discurso ao ser elaborado tem relação com outros textos, como interdiscurso as capas dialogam principalmente com o texto amadiano, sua 
matéria-prima e com outros discursos para os quais a capa aponta, por meio da sua dialogicidade e interpretação, seu futuro discursivo ${ }^{2}$. Pode-se também incluir a relação de forças que liga o ilustrador da capa ao lugar social de onde fala, ao texto que ilustra e ao público-alvo. Ao definir o público-alvo como potencialmente letrado, Clóvis Graciano seleciona os signos através da diegese ${ }^{3}$, antecipando a leitura mediante uma previsão do imaginário do outro. Assim o capista escolhe os signos para a sua ilustração para que o leitor-observador faça a seletividade em sua interpretação de acordo com o objetivo almejado ${ }^{4}$.

Cada signo que o ilustrador usa, pressupõe uma transparência, identificação e entendimento pelo público-alvo mediante a sua cultura.

Considera-se transparente toda cor impressa que se deixa atravessar pela luz, evidentemente clara, ou que permite distinguir nitidamente. Adimitindo-se que o livro é a "luz" que dá a conhecer alguma coisa, a ilustração deverá demonstrar, pela sua transparência, o entendimento que o ilustrador tem da obra literária. Sendo assim, procurou-se observar o que transparece no discurso não-verbal, admitindo como mais transparente e semelhante às formas e cores que podem ser lidas através da relação.

Foi observada, inicialmente, a capa da primeira edição brasileira pelo tamanho dos dois retângulos que a compõem: um maior, que dá o formato da capa, no qual estão colocados nome do autor da obra literária, título do romance, editora e, dentro dele, outro retângulo menor, onde está condensada uma maior quantidade de informações. Neste, a imagem vem dividida em três planos, como se houvesse uma superposição, indicando ao observador, num padrão estimulador, o ritmo da leitura mediante o tamanho dos signos. Esse tipo de trabalho justifica a reflexão de Arnheim (1992, p.8) de que:

Na experiência perceptiva esse padrão estimulador cria um esqueleto estrutural, um esqueleto que ajuda a determinar a função de cada elemento pictórico dentro do sistema de equilíbrio da totalidade, serve como moldura de referência, da mesma maneira que uma escala define o valor de altura de cada tom numa composição musical.

A descrição da capa será realizada a partir da idéia de Arnheim e do ritmo provável de observação. Ao olhar para a capa, possivelmente o observador irá fixar seu olhar, em primeiro plano, no signo de maior tamanho ou destaque na composição artística da capa: a imagem de um homem e de uma mulher adultos, 
de tez clara e traços fisionômicos de pessoas brancas, cabelos lisos, vestidos com roupas escuras e, aparentemente, se olhando. Em segundo plano, em tamanho menor, numa representação assimétrica, vê-se acima uma janela aberta com uma imagem de mulher, do lado esquerdo do observador da capa, no plano intermediário. Esta figura de mulher está desenhada mais toscamente, como se estivesse numa perspectiva um pouco mais distante do casal representado abaixo. Está vestida de branco, com um decote profundo e longo, em direção aos seios, insinuando parte deles, em contraste com a mulher colocada em primeiro plano, com decote discreto, aberto para as espáduas e ombros, sem deixar nada aparecer. Em terceiro plano, há uma corrente de água, talvez o mar e um cais, como um local de fronteira. Acima da corrente de água, a imagem de um casario nas cores cinza, verde, vermelho e branco. Há uma simetria entre o fundo de cor do conjunto de casas e o fundo da imagem onde está representado o casal, sugerindo uma articulação entre casal e casario.

A diagramação induz o olhar do observador a um ritmo ascendente. A forma induzida pela diagramação demonstra dois triângulos que, pela suas formas, sugerem uma interpretação com base na posição fisiológica do homem, isto é, vertical pela força da gravidade e horizontal pelo plano de apoio que the é dado. Como esses triângulos estão virados para a esquerda, parecendo estar sustentados pelos vértices, passam a indicar uma direção que, no caso, pode demonstrar ação e movimento para a esquerda, pela direção e instabilidade da figura que se sustenta por um vértice.

A fonte utilizada no título está em duas proporções e dois tons de uma mesma cor, o marrom, e percebe-se que esta fonte possui um estreitamento lateral maior na citação Cravo e Canela, talvez para caber no espaço determinado para colocação do título na capa. $\bigcirc$ estilo da fonte demonstra seriedade, uniformidade, estrutura estreita e uma retilínea verticalidade retangular. A estrutura da letra parte de um retângulo, com base mais estreita que a altura, tornando-a condensada, e esta fonte "semibold" provoca um destaque na configuração da página.

Seguindo a diagramação, depois que se percebe o nome do romance, vê-se o nome do autor da obra, Jorge Amado, e, como se estivessem atrás desses nomes, algumas casas soltas como um prolongamento do casario representado abaixo. Finalmente, em tamanho bastante discreto no rodapé da capa, o capista coloca na diagramação a citação do gênero dessa obra literária - romance e, 
um pouco mais abaixo, o nome da Livraria Martins Editora. Todos esses signos estão distribuídos sobre fundo amarelo claro ou creme.

As cores são classificadas segundo suas características e formas de manifestação. Alguns autores consideram as cores que são indecomponíveis, como primárias e que a mistura de duas dessas cores gera uma cor secundária. Levam esse nome, inclusive, porque não são consideradas as principais no fenômeno de percepção da cor, variando a denominação de primárias e, conseqüentemente, secundárias se forem cor luz ou cor pigmento. A cor secundária é sempre uma nova cor formada pelo equilíbrio de outras duas cores. Esse fenômeno que ocorre com as cores, acontece, de forma semelhante, nas capas quando o discurso não-verbal, que ilustra, é ancorado, explicado ou, às vezes, tem seu sentido modificado, pelo discurso verbal agregado. Essa ancoragem funciona como se fosse um novo pigmento adicionado ao visto anteriormente, que, pela junção, modificou a sua tonalidade. Neste sentido, é importante observar os discursos verbais que ancoram as ilustrações das capas para que possam ser percebidos os novos "tons" que surgem.

Quanto a cor secundária ou o discurso verbal nota-se que nas orelhas e na quarta capa dessa edição, há três textos: um discurso jornalístico intitulado "Gabriela, Cravo e Canela", sem nenhuma referência de autor, constituído de quatro parágrafos que tratam sobre o produto (livro), o escritor Jorge Amado, sua popularidade, e sobre a divulgação e tradução das suas obras. É uma narração de fatos, em exposição clara e objetiva, com definição resumida da obra amadiana, usando argumentos de probabilidade, de acordo com os índices apresentados. Nesse discurso, há duas formações discursivas que se relacionam com duas formações ideológicas. Na primeira, Gabriela, Cravo e Canela, um romance de amor e crônica de uma cidade do interior, e, na segunda, Jorge Amado, um escritor de popularidade universal e um dos ficcionistas mais traduzidos do mundo.

$\bigcirc$ sujeito da enunciação comunica-se com o leitor num discurso indireto, alternando entre o estilo comentado com verbos no tempo presente "volta", "encontram", "atingem", e o estilo narrado com verbos no pretérito imperfeito e perfeito como "transformavam" e "levou". Utiliza-se de um padrão jornalístico com os verbos em terceira pessoa, colocando-se distante da cena, acentuando a subjetividade e funcionando como observador que conhece as fontes e situações narradas, mas tornando seu discurso imparcial como se os fatos narrados fossem de domínio público. Apresenta ainda alguns pensamentos como se estes fossem 
${ }^{5}$ Ilia Ehrenburg, nascido em Kiev, em |89|, e falecido em Moscou, envolveu-se em agitações revolucionárias, foi obrigado a deixar a Rússia em 1908 e exilar-se em Paris. Tornou-se correspondente de guerra na frente ocidental e voltou a seu país em 1917. Lançou vários livros de sucesso sempre com temáticas políticas e sociais. Era amigo da família Amado e espécie de porta-voz do governo soviético (AMADO, 1999). definições que reforçam o sentido de "verdade". Esse discurso jornalístico qualifica positivamente a obra literária amadiana e sua posição no mercado. $\bigcirc$ sujeito da enunciação, revestindo-se da posição de especialista, afirma como quem sabe ver, por isso sabe dizer, e, na sutileza do seu enunciado, cita os seus juízos de valor, inclusive com palavras de valor axiológico como "célebres", "ardente", que provavelmente passarão despercebidas pelos leitores, mas que irão provocar a reação de querer ler e comprar o livro Gabriela, Cravo e Canela. Os enunciados são organizados, no sentido da afirmação e da assertividade: "...o mais popular...", "Gabriela é ...", apesar do sujeito da enunciação se representar, sempre, na impessoalidade.

Outro texto impresso em uma das orelhas da capa desse livro - "O amor do soldado" - informa sobre um lançamento literário do mesmo autor que foi incorporado à coleção "Obras de Jorge Amado", publicada pela Editora Martins. Este texto divulga que, a partir daquele momento, a obra $O$ amor do soldado estará à disposição do público para compra. Trata-se de uma peça teatral inicialmente chamada $O$ amor de Castro Alves e recebeu o novo título $O$ amor do soldado para evitar confusão com o ABC de Castro Alves (AMADO, 1999)

O terceiro texto colocado na quarta capa é o fragmento do discurso crítico de llia Ehrenburg 5 , romancista soviético, sobre o romance Terras do Sem Fim, também de autoria de Jorge Amado e publicado na União Soviética em 1955. Ehrenburg comenta alguns personagens do romance, especificando sua forma de vê-los e o que mais the agrada neles, elogiando sempre o trabalho literário de Amado.

Nessa primeira edição de Gabriela, Cravo e Canela, os editores se utilizam do discurso jornalístico para divulgá-lo, ao lado da avaliação crítica de um outro romancista conhecido internacionalmente, que tinha afinidades ideológicas com Amado, reforçando a representação profissional e ideológica do autor no mundo social e intelectualizado do Ocidente. A autoridade adquirida pelo espaço conquistado pelo romancista russo, respeitado principalmente nos países ocidentais, provavelmente funcionaria como legitimação das qualidades profissionais de Amado, citadas no texto jornalístico da capa.

O discurso crítico, assinado por Ehrenburg, pode ter sido escolhido estrategicamente pela editora ou por Amado (por causa da amizade) para contagiar o leitor com o poder e a posição de reconhecida autoridade do romancista soviético que, mediante sua força argumentativa e a credibilidade de suas informações, reforçaria 
as outras informações presentes na capa. Por outro lado, sendo uma narrativa que ameniza as regras/normas comunistas, divulgadas em romances anteriores, alternaria a mudança de foco do autor, ampliando o espectro de público-leitor. A crítica de Ehrenburg reafirma os laços entre autor/oprimidos/causas sociais, atraindo e revalidando a leitura para um público de ideologia socialista. A escolha de um texto sobre Terras do sem fim, escrito na década de 40, também articula o desdobramento da temática já trabalhada, bem como a maneira de olhar as relações de poder, reafirmando ao leitor sua continuidade. A ancoragem do texto verbal pode induzir a várias interpretações, mas o que irá produzir a interpretação de cada sujeito, de acordo com sua experiência de vida, é a relação com o contexto, associada às demais representações e ao olhar ou visão de mundo de cada leitor.

De acordo com o ângulo da luz, as cores podem mudar de matiz, ou meIhor, a cor aparente, a sensação visual, torna-se mutante, alterna, criando um efeito sobrenatural, efeito de várias cores cambiantes, que se modificam simultaneamente. Na percepção, admite-se uma cor chamada furta-cor que se modifica a depender da posição em que se encontre o observador. A construção do nome dado a esse fenômeno demonstra a sensação que acontece. Furtar significa roubar, apoderar-se desviar, exatamente o que uma cor faz com a outra que também pode ser vista, mas oscilando no momento da observação. Ao se perceber a existência dessa cor, pode-se relacioná-la com a importância da posição de quem lê e observa uma cor ou um texto verbal ou não-verbal e as diferentes relações que serão feitas, a depender de onde o observador se encontre. Com base nessa premissa, foram delineadas algumas das possíveis relações que a capa pode ter com o trabalho amadiano, com a autoria e a situação do contexto no momento da criação.É importante registrar, mais uma vez, que essas leituras foram feitas através do olhar de alguém que vive na Bahia e conhece a cultura descrita por Amado no romance. Para tanto, será observado os tons furta-cores, ou seja, as várias relações culturais.

Supondo que a interpretação feita pelo capista é resultado do diálogo com o texto amadiano, a ilustração do casal, que está em primeiro plano, na capa, tanto pode estar representando a família dos coronéis, a influência marcante dos seus valores, quanto as relações interpessoais com seus inúmeros preconceitos e a rígida divisão de papéis. Nesse romance, Amado mostra o conservadorismo da família burguesa ilheense, a posição social da mulher subordinada ao marido, responsável sempre pelos afazeres domésticos, pela educação dos filhos e pela 
prática religiosa. Dessas mulheres consideradas "de família", com as quais os coronéis casavam, eram exigidos atributos tais como boa posição social, virgindade e, depois do casamento, a maternidade, submissão, dotes culinários e religiosidade, além do eterno zelo pela honra do marido. Aos homens, reservavam-se as atividades ligadas ao exercício do poder político, econômico, social e cultural, o domínio do contexto familiar, o controle de esposas, filhos e de outras mulheres solteiras da família, além do direito de circularem livremente nas ruas da cidade, terem amantes e as manterem.

Há outra possibilidade de leitura. $\bigcirc$ casal, pelas marcar formais registradas, pode ser a representação dos personagens D. Sinhazinha Guedes Mendonça, esposa do fazendeiro Jesuíno Mendonça, e o cirurgião-dentista Dr. Osmundo Pimentel, casal de amantes que, na trama amadiana, são assassinados. D. Sinhazinha Guedes de Mendonça, senhora da sociedade ilheense, envolve-se numa relação amorosa com o seu dentista, Dr. Pimentel, e são denunciados por uma carta anônima. Surpreendidos, são assassinados pelo marido traído, como era de costume na sociedade local. A senhora Sinhazinha, ao praticar adultério, transgrediu as normas da sociedade de Ilhéus. Essa transgressão a colocava como devassa e imoral pelos conservadores, principalmente porque ia de encontro à moral cristã e à lei dos coronéis. Se o casal da capa representa esses personagens, o sentido seria o de destacar os valores da sociedade local. Eles são punidos como forma de resguardar o código moral imposto pelos coronéis de "lavar com sangue a honra manchada", demonstrando assim o poder masculino.

Vale lembrar que a representação é uma atividade interpretativa que se associa ao contextual para produzir significados aceitáveis pela comunidade leitora. Na cultura do público-alvo, leitor virtual dessa edição de Gabriela Cravo e Canela, o preto e as cores escuras, usadas na representação das roupas do casal, são consideradas:

[... ] ausência de luz. Teoricamente a síntese subtrativa das cores pigmento, muito usadas para representar o frio, aflição profunda, a angústia, frustração, impossibilidade, perda, a dor e o luto devido às proclamações do cristianismo no meio social. (PEDROSA, 1982, p. 1 19).

Outra possível articulação pode vir associada à figura do casal no relevo ao corte tradicional e à cor dos trajes. Pode estar sinalizando status social e econômico, formalidade e requinte dos trajes cerimoniais, mais uma das pistas que antecipam 
a atmosfera da narrativa se associarmos essa representação à perspectiva dos personagens D. Sinhazinha Guedes de Mendonça e o dentista Dr. Pimentel, ou a um estereótipo de casal de classe abastada.

No fundo da imagem que tem como figura o homem e a mulher, o capista dá uma coloração cinza, mistura das cores preta e branca. Cor considerada sem movimento, neutra, "tom rompido" ou tom rebaixado pela mistura de duas cores complementares, o cinza pode ter sido usado pelo capista para provocar no observador uma sensação semelhante à estagnação e à tristeza, que parecem envolver os personagens que compõem a cena ou, ainda, a monotonia da vida dos casados na sociedade ilheense.

Em segundo plano, o ilustrador parece representar a personagem Glória, descrita por Amado como jovem, morena, de lábios carnudos e ávidos e de olhos entornados em permanente convite, "manceba" do coronel Coriolano Ribeiro, que vivia num casarão da praça principal, solitária e prisioneira, a observar o movimento da cidade pela janela. Na trama, Glória usa sempre decotes em seus vestidos que deixam à vista os seios, que pareciam estar sobre uma bandeja, em permanente oferecimento quando estava na janela. Glória também transgride as normas sociais ilheenses por estar à margem da família, sendo malvista e discriminada pela população, por ser amante de um coronel, embora ocupe uma casa no centro da cidade. A posição dessa personagem, no romance, é aparentemente de passividade, submetendo-se sempre às ordens do seu amante, para garantir sua sobrevivência. Como protegida de um coronel, a "manceba" ou "rapariga"6, como é designada, transformava-se em objeto sexual, disponível para o prazer masculino. Suas desobediências eram resolvidas pelo amante com maus-tratos físicos e psicológicos, espancamentos e abandonos.

A representação desse personagem lembra as várias citações de Amado em que Glória aparece na janela da casa em que vivia, na praça principal da cidade, perto da Igreja. Como mulher fora do casamento, não poderia morar perto da Igreja e se expor em plena praça principal da cidade, onde residiam as famílias tradicionais. É provável que o capista a tenha representado numa moldura, a janela, não só para lembrar o confinamento em que vivia, como também para destacála como fora dos limites daquele meio social.

A presença de Glória na capa, em posição assimétrica, pode estar simbolizando uma ameaça à estrutura familiar e às leis coronelistas conservadoras. $\bigcirc$ desequilíbrio da estrutura familiar pode significar desequilíbrio das práticas sociais e princípios 
Prossêmica - estudo explicativo das distâncias a que me ponho de outra pessoa, que comigo mantém um relacionamento qualquer, mostrando que os relacionamentos espaciais estão carregados de significados que mudam de civilização para civilização (ECO, 1997). respeitados pelos cidadãos, e se constituem em ameaça ao establishment. A quebra da estrutura familiar, segundo as teorias marxistas, progressivamente pode provocar uma ameaça à hierarquia social baseada no sangue, na terra, nas tradições e no poder.

Assim, a família representada na capa, como lugar de constituição da memória, pode expressar as relações de poder e força da sociedade, o que deve ser dito, enquanto Glória representa o confronto entre as práticas culturais da época e a possibilidade de transgredir e romper com o historicamente instituído. Ela pode estar simbolizando, então, o isolamento, o que deve ser excluído, lembrado, mas logo esquecido.

A janela como código tipológico, que conota junto com a casa a ideologia do habitar, oferece uma leitura interpretativa prossêmica ${ }^{7}$ em que o espaço fala e esclarece o valor social de cada distância. A casa é um teto que abriga, acolhe, protege, assim como a janela é óculo, abertura. Na composição da capa, além de estarem implícitas essas leituras, a janela lembraria que este é o único elo de ligação da personagem Glória com a vida social de Ilhéus, como evidencia Amado.

Esses dois planos podem estar enfocando duas situações transgressivas na sociedade: a da esposa que ultraja a honra masculina traindo o marido, e a da mulher que mantém relacionamento extraconjugal com um coronel. Podem, ainda, estar enfocando a relação aparente - marido e mulher - e as regras implícitas - casamento e adultério. A família e as transgressões às regras sociais e às leis dos coronéis são discutidas durante toda a trama do romance, mostrando as posições dos partidários do poder e seus valores tradicionais e do grupo de oposição, interessado nas transformações sociais e políticas da cidade, culminando o enredo com o julgamento do coronel assassino, como sinal de modificação dos costumes sociais.

Em terceiro plano, percebe-se o mar representado na cor verde, cor secundária e ponto de equilíbrio entre o azul e o amarelo, cores diametralmente opostas pelo grau de luminosidade e percepção, representando, na cultura do público-alvo, repouso das tensões, calma, passividade. Acima do mar, há traços que lembram um cais e um casario. As casas lembram a cidade de Ilhéus no período do romance (década de vinte). Casas estreitas, compridas, com vários andares e muitas janelas, unidas umas às outras, e sempre posicionadas na organização da cidade num padrão tradicional, com pequenas diferenças nos acabamentos decorativos, beirais e pinturas. Esses tipos de casas, chamados sobrados, 
localizados nas avenidas principais de llhéus, perto do mar, podem representar a história ilheense e estão relacionados aos coronéis, os dominadores, que ditavam os caminhos da vida da cidade. Essas construções arquitetônicas criavam um contraste com as casas dos pobres, que eram térreas e sempre localizadas nas ruas estreitas e secundárias da cidade.

capista ainda representa três casas fora do retângulo menor, com tamanhos variados e aparentemente assimétricas, provavelmente para que o observador, mediante a constância perceptiva, tenha a sensação de distância entre algumas casas, assim como o prolongamento e a dimensão da cidade narrada por Amado conduzem o olhar do observador ao título do livro e ao nome do autor da obra literária, formando os triângulos, citados anteriormente, na linha da diagramação.

O telhado e os muros ao lado das casas estão representados na cor vermeIha, lembrando proteção, não só pela função do telhado, como também porque, em sua maioria, os telhados das casas nas cidades do país do ilustrador são dessa cor, devido ao material utilizado, o barro avermelhado ${ }^{8}$.

A técnica artística usada para ilustração da capa é a xilogravura (técnica muito usada na época para ilustração de livros), marcada por traços retilíneos, geométricos. Aliados à expressividade da técnica, estes traços passam, inconscientemente, para o observador, a sensação de tranquilidade, de ordem em uma cidade interiorana, apenas pela assimetria das casas isoladas e pela presença da mulher na janela, colocada na capa num plano intermediário, ocupando parte dos dois retângulos.

A linha ascendente da diagramação passa uma sensação para o observador semelhante à sensação de progresso almejado e discutido no enredo, da mesma forma que a distância dos personagens, representados na ilustração, induz à distância de alguns personagens na trama. Arnheim (1992, p.9) tem uma explicação que condiz com esse modo de ver: "Ver é a percepção da ação".

Apesar do título Gabriela Cravo e Canela ter sido colocado em superposição e dividido em dois planos diferentes, estes tendem a ser vistos como uma mesma configuração, indicando inteireza, associação e paralelismo. Essa sobreposição, apesar da mudança de cores, intensifica a relação formal dos dois planos interrelacionados, concentrando-os num padrão unificado. Os tons sépia e marrom escuro usados nesse título podem associar-se à cor da canela e do cravo, epítetos da personagem de Amado, ou à mestiçagem baiana. 
Além do mais, o enfoque dessa capa não lembra apenas a narração de Amado no romance, mas um processo histórico-social que, na época do lançamento da edição, acontecia em nosso país. Brandão (1979, p.49) assim coloca essa questão:

O sujeito é essencialmente histórico. E porque sua fala é produzida a partir de um determinado lugar e de um determinado tempo, a concepção de um sujeito histórico articula-se outra noção fundamental: a de sujeito ideológico. Sua fala é um recorte das representações de um tempo histórico e de um espaço social

Reação contra forças conservadoras, esperança de um possível progresso anunciado devido aos acontecimentos políticos da época, como também o fantasma de um coronelismo que aparentemente tinha acabado, mas cujos traços ainda circulavam, caracterizavam o Brasil no período do lançamento de Gabriela, Cravo e Canela. A temática do romance e a capa estavam, portanto, atualizadas e poderiam provocar uma forte identificação com o provável leitor-consumidor.

Se o destaque escolhido e usado por Graciano foi o casal assassinado na trama do romance, provavelmente chamaria a atenção dos possíveis leitores para um problema social. Isto talvez tenha sido posto em evidência para que estes leitores, ao se identificarem com a capa, comprassem e lessem o livro e, em consequência, refletissem sobre a ordem social e sobre a divisão de papéis entre homens e mulheres, presentes no romance e no ambiente social em que os leitores se inserem, já que a capa é a única ilustração do livro.

A posição dúbia da mulher como esposa e "rapariga" pode ser uma chamada para o casamento sacralizado e a relação prazerosa, numa tensão própria da moral cristã, que diferencia sexo para reprodução de sexo por prazer. Talvez a intenção do autor tenha sido representar a esposa junto ao marido, como numa foto de álbum de família, e a outra mulher como se estivesse presente na vida do casal, mas em outro plano, no do prazer. Pode ter pretendido demonstrar, também, um triângulo amoroso, possivelmente destacado porque este tipo de relacionamento não acontece apenas no texto de Amado, mas também no contexto social do público-alvo do romance, provocando, portanto, uma identificação.

Não se pode esquecer que relatos literários, sendo ficções, são construções elaboradas como se os acontecimentos não tivessem ocorrido e os personagens não existissem, mas podem ser um modelo simbólico da expressão, da representação e visão de mundo do seu autor. Tal visão de mundo pode, inclusive, estar 
relacionada a situaç̃̃es contemporâneas, inseridas conscientemente no discurso e modificadas pela criação e adaptação. Assim, o ilustrador, como um coenunciador que deveria construir um discurso atraente, possivelmente procurou destacar na capa o que pensava chamar mais atenção do público-leitor-consumidor, tendo em vista a semelhança entre as situações que aconteciam no enredo do romance e no Brasil na época do lançamento dessa edição. Neste sentido, pode-se de antemão justificar que, tendo o livro várias edições, também vai requerer outras capas, outros invólucros para atualizar os significados ou criar novos sentidos que vão ocorrer no percurso da recepção crítica da narrativa. 



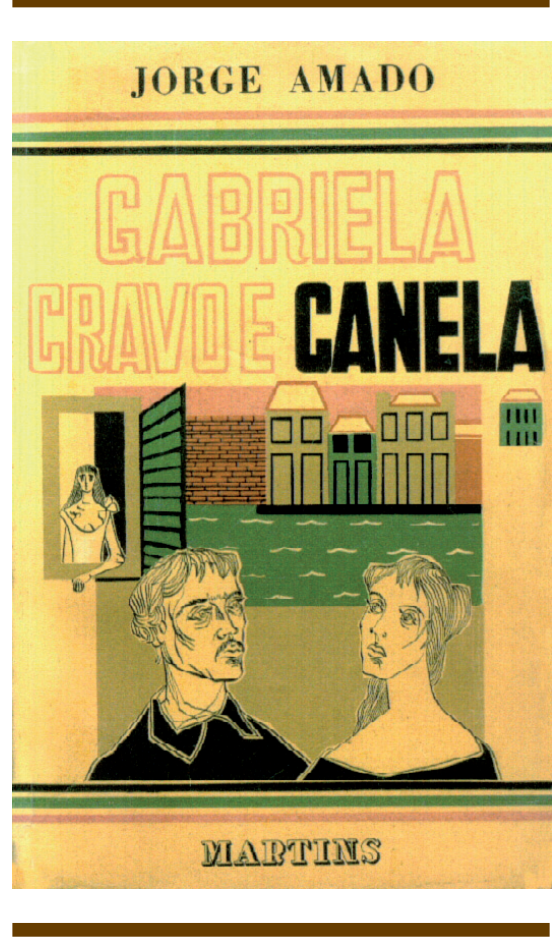

\section{Segunda Capa}

Título Gabriela, Cravo e Canela

País BRASIL

Editora Livraria Martins Editora

Ano 1966

Autoria da capa Sem Referência

Autoria da llustração Clóvis Graciano

Técnica a ilustração XILogravura 
uanto aos pigmentos terrosos ou o contexto no momento do lançamento nota-se que a segunda capa brasileira foi lançada pela Editora Martins em 1966, quando foi criada a coleção OBRAS ILUSTRADAS DE JORGE AMADO, em comemoração aos trinta anos de atividades literárias do escritor e vinte anos de vida editorial da Livraria Martins. Foram reeditadas dezesseis obras de Amado, inclusive Gabriela Cravo e Canela, todas ilustradas por artistas renomados. Completando a coleção, acompanha o livro Jorge Amado: 30 anos de literatura no qual a editora publica estudos, artigos, crônicas e opiniões sobre a obra amadiana. Essa edição foi lançada oito anos depois da primeira e, nesse período, já estava sendo veiculada pela Rede Tupi de Televisão a primeira novela baseada no romance Gabriela, Cravo e Canela, com direção de Maurício Sherman e estrelando Jeanete Vollu, com relativo sucesso de público, como também já havia sido publicada a primeira edição em quadrinhos pela Editora Brasil América, com quadrinização de Fernando Albagli e desenho de Ramón Llampayas.

Era um outro contexto. Em 1964, o golpe militar dividiu a população e diminuiu a liberdade individual. Em 1966, os jornais brasileiros destacavam, na política, a formação da Frente Ampla, união de Juscelino Kubtschek, João Goulard, ex-presidentes, e o ex-governador do Rio de Janeiro Carlos Lacerda, que tinham como objetivo uma união para a liberdade, para a paz e para o desenvolvimento.

A chamada Frente Ampla pretendia a realização imediata das eleições livres, reformas partidárias, a retomada do desenvolvimento econômico e a adoção de uma política externa independente. Essa Frente, considerada depois como aliança dos derrotados, foi dissolvida pelo regime ditatorial, pouco depois da sua formação. No meio cultural, a Jovem Guarda tinha uma audiência recorde e a minissaia fazia sucesso, a partir de sua popularização pelas modelos ocidentais, altas e muito magras, que ganhavam espaço na mídia e no mundo da moda. A mídia, principalmente a TV, começava a ter maior espaço, controlando o interesse, a informação e cuidando da opinião popular. 
As manchetes internacionais, em sua maioria, salientavam o presidente comunista chinês Mao Tsé - tung que havia feito uma divisão geopolítica no mapa mundial, nomeando os países capitalistas e desenvolvidos de "Primeiro Mundo", o bloco socialista de "Segundo Mundo" e os subdesenvolvidos de "Terceiro Mundo". Naquele momento, ele lançava, em seu país, uma revolução cultural proletária contra o aburguesamento, eliminando os burocratas, destruindo as bases da cultura burguesa, chegando a ponto de varrer da China os considerados símbolos dessa cultura, como estátuas, obras literárias e teatrais. No que se refere à América do Sul, esta região mergulhava na ditadura, e a Argentina era citada nos jornais, em virtude do golpe militar liderado pelo general Juan C. Onganía, que veio a depor o presidente eleito.

A Organização das Nações Unidas (ONU) tinha posto fim ao domínio sulafricano na África do Sudoeste (Namíbia), iniciado após a Primeira Guerra Mundial, assim como quatorze países aliados dos EUA tinham rejeitado a exigência da França de controlar as bases da Organização do Tratado do Atlântico Norte (OTAN) em seu território. Ainda floresciam por todos os cantos movimentos pela emancipação do chamado "Terceiro Mundo".

O conjunto musical Beatles já fazia turnê por alguns países da Europa e, nesse período, já haviam ocorrido muitos lançamentos do romance Gabriela Cravo e Canela em outros países, como indica o texto das orelhas nessa edição de 1966.

Ao tentar observar o aglutinador ou ilustrador percebe-se que a capa da edição 1966 é a reprodução da primeira capa ( 1958), com algumas modificações da ilustração de Clóvis Graciano.

Há, nessa edição, sutis diferenças da capa quanto ao que poderemos chamar de transparência ou o discurso não-verbal observa-se que esta capa é diferente da anterior quanto à diagramação e às cores. Na quarta capa, a editora apresenta um texto enumerando as obras que fazem parte da coleção e ao lado, na posição vertical, representações de alguns personagens desse romance, como jagunço, palhaço, cangaceiro, beato, cavaleiro em seu cavalo e o mesmo casal representado na primeira capa com uma casa ao lado, no centro das representações. Essas imagens estão impressas sobre fundo de cor rosa, em destaque no tom creme de toda a capa. Nas orelhas, há dois textos: "Obras llustradas de Jorge Amado", na orelha da primeira capa, e "Gabriela Cravo e Canela", na orelha da quarta capa.

Diferenciando-se da edição anterior, a capa de 1966 possui modificações leves com relação ao traço ilustrativo, apresenta o título impresso na cor rosa, em 
fonte vazada, com destaque para a palavra Canela, que vem impressa em fonte cheia, na cor preta. A fonte utilizada é semelhante à da capa anterior (1958), modificada apenas por ser vazada, com contorno cor-de-rosa, destacando a palavra Canela que está em fonte "semibold". Algumas representações que, na capa do ano de 1958, eram coloridas em vermelho, nesta aparecem de cor diferente, como o muro e o telhado dos casarios, agora impressos em rosa. Também as imagens que representavam as casas distantes, foram omitidas, permanecendo apenas uma fora do retângulo na qual se percebe um maior adensamento de informações.

As modificações na cor podem ter sido feitas pelo autor da capa ou pela editora, para lembrar o mundo feminino mediante a representação que a cor rosa assume na cultura brasileira. Esta cor possui uma relação forte com o mundo das mulheres devido às influências trazidas pelos europeus durante a colonização. As meninas deveriam ser representadas de rosa, como a cor da pintura dos altares dos santos femininos nas igrejas da religião católica. Os meninos de azul, como a cor dos altares dos santos masculinos. Enfim, as virgens de branco, cor que representa a pureza, como observa Pedrosa (1982). Essas pequenas modificações podem ter sido feitas para dar um destaque a esta nova edição, sendo que a repetição da capa original na coleção deve-se, provavelmente, à necessidade de uma retomada às circunstâncias histórico-sociais da capa anterior e de uma repetição do já conhecido. A repetição viria reforçar a ideia evidenciada anteriormente, no momento do lançamento da capa do ano de 1958, e que ainda estava contextualizada, como também reafirmaria e legitimaria o lançamento editorial de grande sucesso. A mudança da cor para rosa suavizaria o debate ideológico, deslizando o sentido para os problemas familiares.

Em suma, esse recurso de repetição da capa não teria apenas o resultado prático de inovar e atrair consumidores pelo sentido da informação do discurso não-verbal. Essa capa passaria, então, a ser um símbolo de uma edição esgotada, devido ao sucesso e, em consequência, passaria a ter um novo valor simbólico pela volta desse passado ao circuito do consumo e pela mudança de contexto, como afirma Eco (1997, p.54) em seus estudos semióticos:

Os significantes adquirem significados apropriados só pelo interagir contextual; à luz do contexto, eles continuamente se revivicam através de clarezas e ambigüidades sucessivas; remetem para um significado, mas, tão logo feito isso, surgem ainda mais prenhes de outras escolhas possíveis. 
A noção de repetição envolve a idéia de retorno que, pelo fato de voltar em outro lugar e em outro tempo, não é mais a mesma. $O$ conhecimento da editora e o do capista levaram a reconfigurar a capa, tendo em vista as posições ideológicas desejadas, aproveitando dessa repetição diacrônica, enquanto material disponível para atualização.

Na suposta cor secundária, isto é, no discurso verbal nota-se que o texto "Obras ilustradas de Jorge Amado", colocado na orelha da capa sem indicação do autor, possui apenas uma formação ideológica: uma coleção lançada em comemoração aos trinta anos de atividades de Amado e aos vinte anos da Martins como sua editora exclusiva. Nesse discurso jornalístico e propagandístico, o narrador cita a importância das homenagens e enumera os artistas colaboradores (todos eles de renomado valor), ao mesmo tempo em que faz a propaganda da coleção. Além de citar esses artistas da cena cultural do País, a editora destaca dois deles devido às participações inusitadas, que passam a ser de valor não só artístico como também histórico: Santa Rosa e Oswaldo Goeldi ${ }^{9}$, sendo que este ilustrou o romance Mar Morto pouco antes de falecer, tornando essa ilustração seu último trabalho. O primeiro livro ilustrado por Santa Rosa foi Cacau, merecendo por isso destaque no texto da orelha desta edição de Gabriela Cravo e Canela. Observa-se que esse texto repete-se em todos os livros da coleção, modificando-se apenas o texto da orelha da quarta capa que se refere, sempre, ao romance de que a capa faz parte.

Ainda no texto "Obras llustradas de Jorge Amado", o narrador utiliza-se de um discurso indireto, sempre em terceira pessoa, marcado pela impessoalidade e pelo distanciamento dos fatos. Utiliza, também, alguns verbos no presente do indicativo, manifestando relações temporais de coincidência do momento da enunciação com o momento do acontecimento, estabelecendo uma relação de continuidade entre dois presentes: um atual e outro progressivo. Também são utilizados alguns adjetivos, como: "excepcional", "magnífica", "maiores", "admirável," "indispensável" e "belas", que emitem os juízos de valor do narrador, mas que, ao serem colocados no meio do discurso jornalístico, dificultam a percepção do leitor de que são palavras que não emitem valores reais sobre o produto. Pelos seus valores axiológicos, os adjetivos qualificam, estabelecendo um ponto de vista crítico e opinatório do narrador. O discurso jornalístico, como "relato de fatos reais", deve, por convenção, estar isento das opiniões de quem escreve, construção oposta ao discurso crítico, que é de caráter opinativo.
Oswaldo Goeldi, gravador e desenhista, nasceu em I 895 no Rio de Janeiro, estudou desde criança na Suíça, retornando ao Rio em 1919. Ilustrou diversos livros, sempre tentando traduzir a atmosfera do texto. Destacou-se pelas notáveis xilogravuras, faleceu em 1961. (Arte no Brasil, 1979) 
O narrador finda o seu discurso jornalístico e propagandístico informando que as obras dessa coleção estavam à venda nas livrarias brasileiras e que poderiam ser compradas pelo crediário, demonstrando mais uma preocupação da editora com o marketing e as estratégias promocionais de venda.

No segundo texto, "Gabriela, Cravo e Canela", impresso na orelha da quarta capa, podem-se identificar duas formações ideológicas: "A Livraria Martins traz ao público a obra-prima do mestre baiano e orgulho da literatura brasileira" e "Gabriela, Cravo e Canela crônica de uma cidade do interior baiano" Nesse texto, o autor também mistura o discurso crítico e jornalístico, provavelmente para que o leitor assimile os juízos de valor do discurso crítico mediado pelo discurso jornalístico, passando despercebidas as diferenças entre o discurso narrado e o comentado.

O locutor utiliza o discurso indireto, com argumentação baseada em exemplos e citações, numa modalidade assertiva, usando, na maioria das vezes, conectivos denotadores de inclusão e adjetivos, como "comovente", "pitoresco", "célebres", "formosa" e "deliciosas", que deixam no sentido do texto marcas da sua opinião como locutor. Os tempos verbais usados são o presente do indicativo, que deixa implícito ser o momento de referência um "sempre", ou seja, o momento do estado, das verdades eternas, o pretérito perfeito, indicando anterioridade ao momento presente, e o futuro do presente, posterioridade ao momento da locução. Esses tempos verbais são marcas formais que esclarecem a posição do locutor em relação ao texto, como diz Koch (1997, p.54) em suas colocações sobre o discurso: "O uso dos tempos do mundo comentado torna um texto explicitamente opinativo, crítico e argumentativo".

Depois de narrar e comentar o romance e ainda informar ao leitor o lançamento da Martins Editora, o locutor finaliza seu texto afirmando que a história do romance já era cogitada como argumento cinematográfico e continuava sendo orgulho da literatura brasileira. Portanto, dezessete anos antes da adaptação cinematográfica, já circulava a idéia de se transformar essa obra amadiana em filme.

Também no último período do texto, o locutor usa a expressão verbal "continuava sendo", que se configura como mais um jogo da enunciação, situando o acontecimento num passado durativo, mediante o uso do imperfeito do indicativo. Esta categoria de tempo induz o leitor a aderir á conclusão do locutor de que Gabriela, Cravo e Canela é orgulho da literatura brasileira. Verdade afirmada no passado e que continua imutável no presente, usada na capa como artifício técnico de persuasão e como armadilha de consumo. 
Nos tons furta-cores ou nas várias relações culturais desta segunda capa percebe-se que o discurso publicitário é repetição da primeira, volta a ser evidenciado o coronelismo que, no período do lançamento, já era considerado como extinto, mas cujos ecos ainda eram ouvidos. Como, no contexto social brasileiro (1966), ocorria um clima de reformas e retomadas do desenvolvimento econômico, esse ambiente deve ter provocado, mais uma vez, uma relação com o enredo do romance, suavizado ou atravessado pelo enredo sobre as mulheres, fazendo com que o capista se utilizasse da repetição da capa anterior, para criar identificações com o público. Embora a ditadura estivesse no início diminuem as mensagens socialistas e comunistas. Foi retirado o texto do escritor da União Soviética, presente na edição anterior, e a referência à saga (luta pelas terras) Terras do sem fim. Ao utilizar uma capa semelhante à capa anterior, a ilustração impressa na capa passa a ser temporizada por meio da sucessão, devido ao prévio conhecimento. O saber hipotético do observador sobre os efeitos de sentidos que serão produzidos com a utilização da imagem posterior, torna-a supostamente conhecida. 



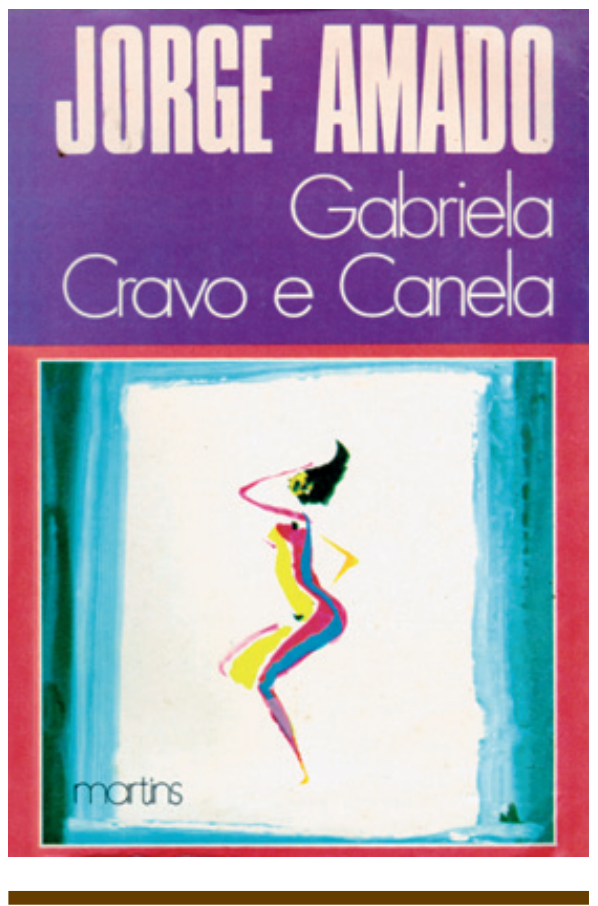

\section{Terceira Capa}

Título Gabriela, Cravo e Canela

País BRASIL

Editora Livraria Martins Editora

Ano 1973

Autoria da capa Sem Referência

Autoria da llustração Héctor Julio BernabóCARYBÉ

Técnica a ilustração PINTURA 
No

ano de 1973, quando foi editada, essa capa, os jornais brasileiros ainda noticiavam a guerrilha de esquerda, a censura ao texto escrito, aos meios de comunicação, torturas, desaparecimento de pessoas e outras formas de repressão adotadas pelo governo militar. A expressão artística em todas as suas formas e, principalmente, a imprensa sofriam censura, chegando ao ponto dos mais importantes jornais do País substituírem algumas de suas matérias por receitas de bolo ou trechos de Os Lusíadas, denunciando o seu confisco pelos organismos fiscalizadores de repressão.

Nas relações culturais ou tons furta-cores nota-se que o regime militar articulou um eficiente sistema repressivo com base nos serviços secretos, principalmente depois do Al-5 (1968), no governo do presidente Emílio Garrastazu Médici (1969-1974). Em consequência, a guerrilha de esquerda, ficou condenada ao isolamento porque seus líderes acabaram assassinados, restando apenas os movimentos estudantis que, sem apoio, terminaram diluindo-se. Mesmo assim, havia no Brasil uma onda de propagandas oficiais com slogans como "Ninguém segura esse país" ou "Brasil, ame ou deixe-o", o que representava uma referência óbvia à oposição. Dentro de um extremado clima nacionalista oficial, o time brasileiro de futebol tinha conquistado o tricampeonato no México em 1970, favorecendo aos governantes militares a exploração dessa euforia e o mascaramento das desigualdades sociais e econômicas do País, que vivia um regime de exceção.

As manchetes internacionais mostravam a reeleição de Juan Perón. $\bigcirc$ Egito ainda aparecia nas manchetes em ataques a Israel e, nos Estados Unidos, os povos indígenas exigiam que o Senado investigasse os abusos cometidos pelo governo contra os índios. Nesse ano também, foi lançada uma edição desse romance de Amado na Turquia.

aglutinador ou ilustrador dessa capa brasileira é o artista plástico, Héctor Julio Bernabó, cujo pseudônimo é Carybé. Nascido na Argentina, em 1911, passou 
a infância na Itália, retornando mais tarde para a América Latina, fixando-se no Brasil onde estudou na Escola Nacional de Belas Artes, no Rio de Janeiro. Em 1950, radicou-se em Salvador, onde já estivera em 1938. As suas pinturas, desenhos e esculturas têm como tema central cenas e tipos baianos. Amigo de Amado, vai fazer parte do grupo que divulga a Bahia pelo seu "exotismo". Suas obras abordavam temas culturais, focalizando orixás do culto afro-brasileiro. É considerado pela crítica como importante pintor expressionista, de traço inigualável e de intenso colorido. Durante sua vida, recebeu inúmeros prêmios, inclusive uma viagem a Paris, onde estudou. Na volta, publicou um álbum de litografias sobre a Espanha. Seu trabalho é reconhecido por alguns críticos como de extrema autenticidade. Faleceu em 1997 na Bahia, lugar que dizia ter escolhido para viver.

Na transparência ou discurso não-verbal dessa capa , percebe-se a divisão do espaço em dois planos. Em primeiro plano, uma moldura, isto é, um quadrado, como se fosse uma janela ou palco, com cortinas laterais, com o perfil de uma mulher. No canto inferior esquerdo, o nome da editora, acima, seguindo o gráfico da diagramação, está o nome do autor, Jorge Amado, numa fonte em destaque na cor branca e, logo abaixo, o título do romance. Essa sucessividade que os olhos do observador percorrem é assim explicada por Huyghe (1970, p.70):

O encadeamento das posições sucessivas provoca uma cinemática e os olhos executam-na, correndo de um ponto para outro, projetando, assim, no espaço móbil que designa.

Na quarta capa, há um retrato do autor assinado por Zélia Amado e, ao lado, um pequeno texto sobre o escritor assinado por Monteiro Lobato. Logo abaixo, vêm os nomes dos romances que fazem parte da coleção OBRAS ILUSTRADAS DE JORGE AMADO, além da assinatura da Livraria Martins Editora. Nas orelhas da capa, está impresso apenas um texto, com o título "Gabriela, Cravo e Canela", que inicia na orelha da primeira capa e conclui na orelha da quarta capa.

Na ilustração da primeira capa, o autor representa um perfil de mulher com uma mão na cabeça e outra nos quadris e com os cabelos em movimento ascendente como numa dança em que todo o corpo se movimenta. Essa imagem de mulher é composta de várias cores, sem definição dos traços fisionômicos, como se quisesse simbolizar uma pessoa de cor ou raça indefinida. Está situada no centro de um quadrado, como se fosse o centro de um palco, com as laterais pintadas na cor vermelha, para chamar a atenção, e azul em vários tons, demarcando 
o espaço. Fixa-se, assim, a atenção do observador para a figura de mulher colorida e situada no centro de um espaço com fundo branco. Neste trabalho, Carybé deteve-se na figura de mulher como elemento principal para representar o conteúdo do romance. A moldura usada funciona como fronteira, manifestando um circundamento da imagem, e definindo-Ihe o domínio ao separá-la do resto da capa. Ao mesmo tempo, propicia à ilustração um formato definido pelo tamanho absoluto dessa imagem, das suas dimensões principais, tornando-a mais nítida e singularizando a percepção do observador. Nessa representação, o isolamento da imagem de mulher pela moldura aumenta o seu valor, condicionando o olhar do observador para o centro da moldura onde se situa a figura de mulher.

- capista, em sua diagramação, evidencia em tipologia maior o nome do autor, provavelmente devido ao prestígio de Amado no mercado editorial brasileiro e utiliza fonte menor para o título do romance.

A diagramação forma um triângulo virado para a direita do observador, no sentido do movimento da leitura ocidentalista, que é da esquerda para a direita, apontando para o nome do romance. Esse movimento também é ascendente, induzindo o olhar do observador para o nome do autor e decresce posteriormente para o nome do romance e o nome da editora, o que já indica a ordem de valor das informações. As fontes usadas diferem uma das outras, e a que imprime o nome do escritor demonstra mais masculinidade pelo estreitamento lateral e maior altura. Já a fonte que indica o título do romance demonstra delicadeza, pelo traço fino, pelo arredondamento e pelo estreitamento vertical.

A cor azul (que emoldura o retângulo no qual está contida a figura de muIher) das cortinas da cena passa, no seu uso mercadológico, uma "[...] sensação de infinito, mistério e transparência”, como afirma Pedrosa (1982, p. I |4):

O azul é a mais profunda das cores - o olhar o penetra sem encontrar o obstáculo e se perde no infinito. É a própria cor do infinito e dos mistérios da alma. Devido a afinidades intrínsecas, a passagem dos azuis intensos ao preto faz-se de forma quase imperceptível. O azul é, ainda, a mais imaterial das cores, surgindo sempre nas superfícies transparentes dos corpos. Por isso, na Antigüidade acreditava-se que ele era formado pela mistura do preto com o branco.

Provavelmente, a cor foi usada pelo ilustrador para dar a impressão de mistério, da visão de uma mulher vista por um óculo à distância, como se fosse uma cena/janela distante do observador, delineada com cortinas azuis. 
A capa tem como ilustração uma forma simples, mas em oposição apresenta muitas cores, o que atrai o observador, pois, naquele período, um anúncio colorido era muito mais atraente que em preto e branco ou com menor quantidade de $\operatorname{cores}^{10}$. Esta capa é uma forma artística bastante particularizada por seu traço e, provavelmente, poderá ser interpretada não somente como uma mulher de perfil, como uma boneca articulada (desenhada em movimento), com muitas cores, provocando várias emoções no observador.

Dentro do contexto social de censura aos textos jornalísticos e artísticos e de Amado, alvo dessa censura, pela sua posição político-partidária, essa representação era mais que oportuna, pois não corria riscos de indicar elementos para uma possível censura. A ilustração apenas rotula a obra como algo em que o assunto principal é a mulher. Essa forma de rotulagem difere radicalmente das capas brasileiras dos anos anteriores de 1958 e 1966, que aludiam à família e à vida dupla dos coronéis. Era ideal para o período histórico com tantas censuras, principalmente ideológicas, pois informava pouco, mas seduzia o leitor com as suas cores, induzindo-o a imaginar e a criar suas próprias respostas e sentidos de leitura"'.

A repressão e a censura violenta podem ter influenciado a editora a decidir pela modificação, para evitar problemas com a censura e com o governo militar. A capa (como embalagem) deve comunicar e ilustrar a obra que embala, e, ao chamar a atenção para outro enfoque social, apaga/faz desaparecer a ideologia sociopolítica. Por outro lado, a legitimidade de Carybé como artista capaz de interpretar as relações sociais baianas pode ter, intencionalmente, ajudado a esvaziar o sentido político da obra.

A quarta capa utiliza-se de parcerias para legitimar o prestígio de Amado no meio intelectual. A foto de Amado feita por sua esposa Zélia, o retrato feito por Carlos Bastos $^{12}$, as ilustrações de Di Cavalcanti, citados no texto da orelha da capa, e a citação de Monteiro Lobato ${ }^{13}$ colocam o autor entre o ambiente íntimo da família ou parentes e amigos e o público. A foto, feita por sua esposa Zélia Gattai, passa para o observador a sensação de veracidade e confirmação dos momentos mais íntimos do escritor, como também a parceria de Monteiro Lobato que, num texto poético, descreve Amado como um ser especial.

Esses discursos, a fotografia de Zélia Amado e a citação de Lobato, assinados por pessoas de destaque para o público-alvo, ao serem inseridos no discurso publicitário, passam a ser uma estratégia de promoção de vendas, pois funcionam como elemento de persuasão, considerando a posição de quem fala e de quem assina.
${ }^{10}$ Segundo Arnheim (1989, p.326-327): "As cores pertencem aos sentidos, essas indicam uma abertura aos estímulos externos, ou seja produzem uma experiência essencialmente emocional, enquanto que a forma corresponde ao controle intelectual".

'Aumont (1995, p.9|) observa que "[...] toda percepção, todo julgamento, todo conhecimento é uma construção, elaborada por meio da confrontação de hipóteses (estas fundadas em esquemas mentais, alguns inatos, outros provenientes da experiência) com os dados fornecidos pelos órgãos de sentido".

${ }^{12}$ Carlos Bastos, artista plástico, baiano, nasceu em 1925, estudou na Bahia, viveu em Nova York e Paris, sempre em busca de aperfeiçoamento. Era amigo de Amado. Pintor de destaque no meio artístico nacional.

${ }^{13}$ José Bento Monteiro Lobato, escritor brasileiro, nascido em São Paulo, em 1882, e falecido em São Paulo, em 1948. Graduado em Direito pela Universidade de São Paulo, autor de várias obras literárias para o público adulto, de méritos indiscutíveis, mas com destaque especial para as suas obras de literatura infantil. 
${ }^{14}$ Emiliano Augusto Cavalcanti de Albuquerque Melo, conhecido artisticamente como Di Cavalcanti, nascido no Rio de Janeiro, pintor que se consagrou por pintar mulatas. Um dos mais notáveis pintores do Modernismo.
Assim, o discurso da capa é um mosaico de citações, com as quais dialoga intertextualmente. $\bigcirc$ texto amadiano, a ilustração, as citações, os títulos e os textos da capa, como também os pré-construídos, assimilados pela experiência e as inúmeras leituras feitas pelo capista, estarão sempre dialogando no processo de efeitos de sentidos, em processo de interação com as interpretações do leitor, tornando-se um diálogo de reconfiguração incessante.

Como cor secundária ou discurso verbal observa-se abaixo da foto e do texto de Lobato, enumerada as dezenove obras de Amado que fazem parte da coleção OBRAS ILUSTRADAS DE JORGE AMADO, lançada anteriormente, reforçando a capacidade profissional do autor e divulgando-a para possíveis e futuros consumidores. O texto "Gabriela, Cravo e Canela", impresso nas orelhas, é uma reedição do mesmo texto da capa da edição 1966, com modificações no penúltimo parágrafo. Trata-se de referência à autoria da capa e aos autores dos retratos, alusão às ilustrações internas da obra, de autoria de Di Cavalcanti ${ }^{14}$, mais um artista de renome que legitima a categoria profissional de Amado. Os vários discursos usados como parcerias estão associados à memória discursiva do capista, que se utiliza de outros discursos como estratégia a serviço da sua argumentação para impressionar o leitor-consumidor.

Observa-se, ainda nessa edição, uma mudança na identidade empresarial da Livraria Martins Editora, que na capa assina com nova logomarca.

Essa capa destaca-se por uma ilustração artística que exige raciocínio lógico e sensibilidade interpretativa por meio da confrontação de hipóteses.

As informações não-verbais impressas terão, provavelmente, como âncora o discurso verbal nas possíveis leituras do público consumidor.

Nos tons furta-cores ou no contexto percebe-se a singularidade da pintura de Carybé. Com o seu traço peculiar, Carybé demonstra a sua percepção e emoção, numa forma singular de representar a mulher. Para que o receptor reconheça e interprete essa nova forma, possivelmente terá que utilizar uma série de pressupostos adquiridos sobre o que é arte, pois a peculiaridade da imagem atinge a representação do invisível, do inefável e do transcendente. Trata-se de uma metáfora. A capa pode representar a Gabriela, ou qualquer personagem feminina do romance. Carybé inscreveu, na ilustração, sua subjetividade criativa e o observador vai identificá-la e atribuir-lhe significado, adequando-a ao contexto e à leitura, e provavelmente procurando relacioná-la aos estereótipos já cristalizados no sistema conceitual da sua cultura. Ou, talvez, o uso da obra de arte pode ter sido 
escolhido, pela editora, como uma estratégia para uma circulação dessa edição, sem problemas com o governo militar, devido ao que acontecia politicamente no Brasil naquele período. 



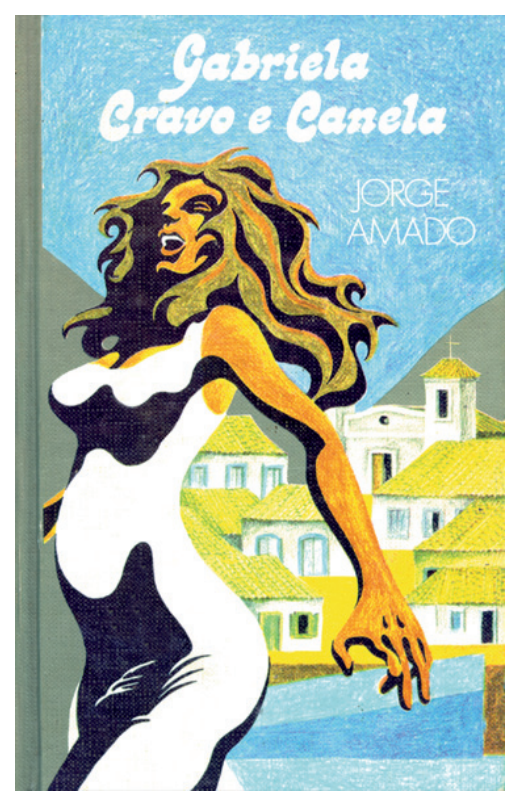

CAPA 4

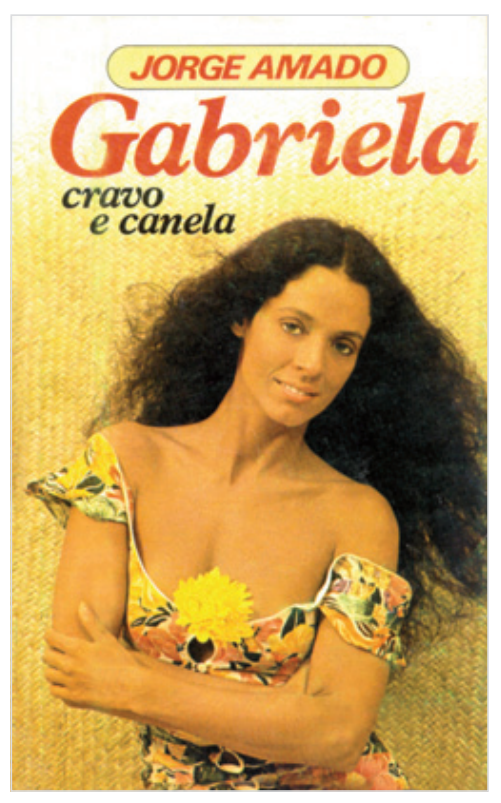

CAPA 5 - Sobrecapa
Quarta e Quinta Capas

Título Gabriela Cravo e Canela País BRASIL

Editora Círculo do Livro

Ano 1975

Autoria das capas Sem ReferênCIA

Autoria das ilustrações

Alfredo Aquino - Capa 4

Sem RefERÊNCIA - Capa 5

Técnicas das ilustrações

GRAVURA NA CAPA

FotograFIA NA SOBRECAPA 
ezessete anos após a primeira publicação, a edição de 1975 apresenta uma capa e uma sobrecapa bastante diferentes: a primeira, com encadernação em brochura, ilustração de Alfredo Aquino, e sobrecapa com fotografia de Sônia Braga que, no período, atuava como "Gabriela", na novela baseada no romance, na Rede Globo de Televisão. $\bigcirc$ ano de estréia da novela foi o mesmo do lançamento dessa edição.

Os pigmentos terrosos ou o contexto demonstram que a ditadura militar ainda imperava no País, sob o comando do presidente Ernesto Geisel, que optou por uma política externa mais independente, diante dos resultados obtidos no comércio com países árabes, especialmente, o Iraque e a Líbia. $\bigcirc$ Brasil tornouse um dos maiores fornecedores de armas para o Iraque. Também nesse período, o País rompeu o acordo militar com os Estados Unidos e assinou convênio com a Alemanha para a compra de Usinas Nucleares. Ernesto Geisel passou para a história como o ditador que iniciou a abertura lenta e gradual do regime militar no Brasil. Por outro lado, a extrema direita não queria a extinção do regime e organizava várias ações para demonstrar sua opinião. Uma delas foi o assassinato do jornalista Vladimir Herzog na prisão, o que provocou um ato ecumênico de homenagem, conduzido pelo cardeal Evaristo Arns, pelo rabino Henry Sobel e pelo pastor Jaime Wright, contando com a participação de dez mil pessoas, que exigiam uma rápida abertura do regime. Surgia, ainda, o Movimento, jornal de oposição à ditadura, tendo como colaboradores Fernando Henrique Cardoso, Francisco Welffort, Eduardo Suplicy e Raimundo Pereira.

$\mathrm{Na}$ Rede Globo de Televisão, estreava a novela Gabriela, Cravo e Canela, baseada no romance do mesmo nome e, em virtude do seu sucesso, a Revista Amiga, da Bloch Editores, lançou uma edição especial para o público do Brasil e Portugal, com uma fotonovela sobre o romance, ilustrada com mais de 400 fotos, em 64 páginas. Além disso, havia sido lançada, com grande sucesso, no ano 
anterior, a segunda edição especial, em quadrinhos da coleção Cinemim, sobre o romance Gabriela, Cravo e Canela. No ano anterior, a Livraria Martins Editora, que ainda detinha os direitos de divulgação dos livros de Amado, tinha pedido concordata e, a partir daquele ano, alguns livros de Amado começaram, também, a ser vendidos em bancas de jornal.

As manchetes internacionais divulgavam o término da guerra do Vietnã, a maior derrota política e militar dos Estados Unidos. Após quatro séculos de domínio colonial, Portugal, influenciado pela Revolução dos Cravos, reconheceu a independência de Angola por combates envolvendo cristãos e grupos palestinos no Líbano, iniciando uma guerra civil. Ainda nesse momento histórico, a ONU aprova moção comparando sionismo a racismo e o Brasil vota a favor. Na Inglaterra, Margareth Thatcher é eleita líder do Partido Conservador britânico, e, na Argentina, os militares já iniciavam um movimento contra Isabelita Perón, viúva de Juan Domingo Perón, morto há um ano, por ser considerada impotente na luta contra o terrorismo dos partidos de esquerda.

No ano anterior, já tinham sido lançadas três edições do romance Gabriela, Cravo e Canela, traduzidas, em armênio, eslovaco e tcheco.

O aglutinador ou ilustrador é Alfredo Brasil Xavier Aquino. Sobre ele não foi encontrada nenhuma referência, inclusive na Summus Editorial, que detém, hoje, os direitos da antiga editora Círculo do Livro. Não foram encontradas referências dele, como artista plástico ou desenhista, em publicações sobre as artes plásticas brasileiras e outras fontes de pesquisa. Também não há referência sobre a autoria da ilustração dessa sobrecapa no livro.

O discurso não-verbal deixa transparecer uma representação mais próxima de uma figura de mulher. Na ilustração, ela está de perfil, vestida de branco, com os cabelos soltos e, por trás dela, um casario em tons amarelo e branco, como se estivesse à beira do mar, representado pela faixa azul na parte inferior. A mulher parece estar em movimento, andando, gritando ou falando.

As suas mãos e a expressão facial demonstram tensão e agressividade. A face lembra uma pessoa que grita com raiva e as mãos estão em forma de garras, como uma mulher que está prestes a se defender ou a agredir alguém. A figura poderia estar representando, também, o povo brasileiro diante da situação social e política no período de lançamento desta edição, já que no Brasil o sistema socioeconômico era bastante repressivo naquele período. Poderia estar apresentando, ainda, a situação da mulher na sociedade ou uma das representações da mulher das classes populares. 
Pode ser, também, que fosse aquele o traço artístico desse autor, já que nenhuma referência foi encontrada sobre seus trabalhos, fazendo com que a análise seja desenvolvida sob hipóteses.

Percebe-se, ainda, que a figura de mulher, vestida na cor branca, passa para o observador a sensação de nudez já que essa cor, como cor pigmento, representa a ausência de cores, isto é, pode significar, muitas vezes, o "não-dito". O corpo está coberto com um vestido branco, muito justo, desenhando as formas da muIher, que não está nua de fato. Possivelmente, representado devido à censura que ainda existia no ano do lançamento.

O casario de fundo sugere, provavelmente, a cidade de llhéus, bastante luminosa, nas cores amarelo e branco (à beira do mar), lembrando as cidades de países tropicais como o Brasil, que possuem na sua atmosfera intensa luminosidade, com o sol forte irradiando luz por toda a parte. Já as montanhas, representadas atrás do casario em cor cinza, lembram morros distantes do olhar do observador. Devido à constância perceptiva, os objetos são vistos em tom mais cinza ou azulado, quanto mais distante o objeto estiver de quem olha, em razão da quantidade de atmosfera entre o olhar e o objeto, modificando, desta forma, a cor "real". O mar e o céu são coloridos de azul; o mar, em vários tons, lembrando o movimento das ondas e a variação de cor devido ao reflexo das cores da atmosfera. As arcadas e molduras de algumas janelas do casario devem ter sido coloridas em tons de azul e amarelo, provavelmente, para lembrar um reflexo da coloração do mar e do sol.

O diagramador coloca, acima da pintura de Aquino, o título do romance na cor branca, sem muito contraste e, abaixo, o nome do autor, na mesma cor. Essas informações, de extrema importância para o consumidor, estão impressas de forma quase imperceptível, não só devido ao pouco contraste entre as cores, como ao tamanho da fonte e à tipologia escolhida. Isso tudo demonstra (ou pelo menos parece) falta de cuidado do diagramador com a representação de elementos essenciais de informação do produto na embalagem ou pode significar o interesse em não chamar a atenção para essas informações. Talvez fosse mais persuasivo chamar a atenção para a construção de sentidos da Gabriela protagonista. Na verdade, o resultado para o consumidor é pouca legibilidade e, consequentemente, uma difícil percepção.

O traço da diagramação demonstra movimento intenso, sugerindo agressividade, concatenando-se com a expressão da modelo impressa na ilustra- 
ção. As fontes utilizadas contrastam entre si. A que imprime o nome da obra é arredondada com serifas, dando a sensação de estabilidade e de peso já que é cheia; por outro lado, a usada para o nome do romance é retilínea sem serifas e com hastes bastante finas, contribuindo para a difícil percepção.

A sobrecapa muda o enfoque anterior, pois se sintetiza em uma foto da atriz Sônia Braga como intérprete de Gabriela. A foto mostra a atriz brasileira que, naquele período, estava encenando a personagem na novela ${ }^{15}$ da Rede Globo de Televisão, baseada no romance Gabriela, Cravo e Canela sob direção de Valter Avancini. É provável que a editora Círculo do Livro tenha colocado esta sobrecapa para que o público estabelecesse uma relação entre a novela e a capa, de forma a estimular as vendas do livro.

É necessário salientar que um texto literário, quando sofre uma adaptação para a televisão ou qualquer outra adaptação, experimenta a coenunciação de outros profissionais de acordo com as especificações da adaptação escolhida. $\bigcirc$ texto se modifica ao passar um novo olhar, uma nova interpretação. $O$ próprio Amado (1999, p.258) diz:

[...] a adaptação de um romance para qualquer outro meio de comunicação é sempre uma violência contra o autor. Por melhor que seja a adaptação, haverá sempre algo fundamental que se modifica, diminui ou cresce, se deturpa ao ser transferido das páginas do livro para o palco ou para as telas, a grande do cinema, a pequena das televisões.

A adaptação do romance para a TV concretizou um novo modelo para a Gabriela que a sobrecapa reproduz, legitimando-o, como se este fosse o modelo definido por Amado na sua narrativa, inclusive induzindo o imaginário do leitor à sua aceitação deste modelo como a descrição da personagem amadiano. As modificações citadas por Amado no processo de adaptação tomam, muitas vezes, proporções irrecuperáveis, já que o leitor, que ainda não tinha lido o romance quando assistiu à novela, provavelmente assimilou o modelo visual, dificultando imaginar outro modelo numa leitura posterior. Quando um autor literário escreve, pinta com palavras, levando o leitor a uma representação de acordo com a relação das informaç̃̃es dadas e com o seu imaginário por meio da dialogicidade. Ao ter um modelo já definido, principalmente na mídia, a sua influência sobre o leitor será muito grande, levando-o, muitas vezes, à aceitação sem questionamentos.

\footnotetext{
15 A referida novela teve como atores principais Sônia Braga e Armando Bogus, obtendo um grande sucesso de público.
} 
A fotografia impressa na sobrecapa mostra Sônia Braga, "Gabriela", em primeiro plano, de frente, olhando para o observador, como se o estivesse vendo olhar para ela, uma reciprocidade de olhar. A personagem está representada com os cabelos cacheados soltos, sorrindo, com um vestido estampado em tons amarelo, vermelho e preto e uma flor amarela no decote. Os cabelos soltos, ondulados ou revoltos estão associados, na cultura do público-alvo, à mestiçagem e, principalmente, à permissividade e à sexualidade, representação que alimenta 0 apetite do observador. Segundo Berger (1972, p.59), "O cabelo está associado ao poder sexual, à paixão".

Há outras reduplicações voltadas para a sexualidade, como o decote do vestido, bastante pronunciado, deixando à mostra parte do seio e provocando no observador a sensação de recomposição da forma vista em parte, de acordo com sua fantasia. Sônia Braga, "Gabriela", nessa foto, está de braços cruzados em frente ao corpo, como se fosse uma barreira. Na cinésica, essa posição dos braços com os polegares para cima, como registrou o fotógrafo, demonstra autoconfiança (mesmo com a barreira de proteção dos braços mantidos horizontalmente, numa versão, possivelmente, defensiva) como afirma Pease (1995, p.89): "O gesto dos polegares para cima é a maneira que temos para demonstrar uma atitude de autoconfiança, e os braços cruzados proporcionam a sensação de proteção". Essa sensação de confiança demonstrada pela modelo passa para o observador a ilusão de tranqüilidade para estabelecer uma "possível" aproximação.

A flor, no decote do vestido, é um elemento da natureza, não só lembra o uso constante deste adereço pelo personagem, no texto de Amado, como também sinaliza para uma mistura de ingenuidade e sensualidade. Quanto à cor amarela da flor e da estampa do vestido, segundo Pedrosa (1982, p. I I I):

O amarelo representa calor, energia, alegria e devido a sua intensa luminosidade, realiza um movimento excêntrico e se aproxima quase visivelmente do observador, quando atrai o seu olho ao foco da composição.

Situada entre os seios, a flor é uma forma de chamar a atenção do observador para o escondido e insinuar sexualidade, permissividade e cumplicidade na troca prazerosa sexual.

A energia passada pela cor e todo o conjunto da imagem enfatizam a vibração da personagem Gabriela na trama: uma mulher cheia de vida e confiança, alegre e sedutora, como demonstra a expressão do rosto da atriz na foto, uma 
máscara facial construída para articular-se com o vestuário e o conjunto representativo da personagem. Essa imagem parece ter sido montada para criar uma relativa intimidade da modelo com o observador, seduzindo-o.

A diagramação indica uma forma fechada na parte superior e vazada na parte inferior, causando a sensação de proteção, de cobertura. As fontes usadas demonstram força, apesar de se destacarem pelas cores e pelo traço retilíneo no nome do autor, e pelo traço arredondado no título da obra.

A representação da ilustração é arquetípica, pois enfoca a mulher sempre suave, passiva, mas sexualmente atraente, o que não passa de um jogo, muito utilizado pela mídia, para seduzir os consumidores homens, mas também é um convite às mulheres a adotarem um comportamento quase teatralmente autodirigido, mediante a identificação com a modelo. $O$ plano de fundo da foto lembra uma esteira de palha trançada, fazendo o observador relacioná-la com os artesanatos, legitimando a cenografia do ambiente fotografado. $\bigcirc$ diagramador coloca acima da fotografia os nomes do romance, dando destaque à palavra Gabriela e ao autor, ambos em cor vermelha, deixando apenas cravo e canela na cor preta. Dá um destaque especial para o nome do autor, também em vermelho, mas colocando-o dentro de uma forma circular, com a cor num tom mais escuro.

Por ser uma representação fotográfica, provoca no observador a sensação de um registro mais "realista" da modelo devido ao sentido indicial inerente a esta técnica.

Percebe-se a diferença entre capa e sobrecapa quanto ao destaque dado ao nome da obra e da autoria, fazendo supor que, enquanto o autor da capa evita dar destaque ao nome da obra e autoria, o autor da sobrecapa põe em evidência essas informações, provavelmente respaldado pelo sucesso da novela.

Na capa, não foi impresso nenhum discurso verbal além do título da obra e o nome do autor, sem maiores destaques. Na sobrecapa, vêm somente impressas as identificações necessárias, título do romance e autoria, mas com bastante contraste. A falta de um texto mais explicativo sobre a obra e o autor nessas duas capas pode sinalizar que não havia necessidade, pelo suposto conhecimento dos leitores ou por ter sido considerada uma edição mais dirigida, destinada aos sócios do Circulo do Livro' ${ }^{16}$.

A capa, elaborada por Xavier Aquino, retrata uma Gabriela aparentemente agressiva, como se estivesse gritando, para lembrar, talvez, a postura de insatisfação da mulher brasileira no período de lançamento da edição. Pode estar associada,
16 "O Círculo do Livro" era uma associação composta de leitores que recebiam, trimestral ou quadrimestralmente, edições encadernadas de livros de autores brasileiros consagrados. A tiragem era específica, de cortesia da Editora Civilização Brasileira, e em cada volume vinha impresso: É proibida a venda a quem não pertença ao Círculo. 
também, à situação política do País, marcada pela injustiça social, repressão e censura. Essa representação poderia estar revelando a inquietação presente na vida do público-alvo. Os primeiros protestos sobre a desigualdade de tratamento das relações de gênero nas práticas sociais começavam a dar sinais da nova muIher: independente, envolvida com a segunda onda do feminismo, movimento pela igualdade de direitos e por direito ao trabalho. Vale salientar que o livro de Amado também propõe a discussão sobre a condição da mulher, expressa nas personagens Malvina e Gabriela, e, como já citado, é comum o capista utilizar traços característicos do contexto do público-alvo para criar uma identificação deste público com o modelo ou a ilustração.

A decisão da editora de colocar uma sobrecapa é muito comum na área de promoção de vendas. A sobrecapa torna-se um anúncio de oportunidade para chamar a atenção e para atualizar a edição com os acontecimentos mais oportunos no contexto do público-alvo. Essa publicação do Círculo do Livro, depois de dezessete anos da primeira edição, talvez tenha sido incentivada pela popularidade do personagem na TV.

Nesse caso, ao receber o livro com a foto de Sônia Braga, a Gabriela, para tê-lo em sua casa, o sócio poderia associar o Círculo do Livro à legitimidade de um autor (que estava sendo desqualificado pela crítica acadêmica), mas estava sendo divulgado pela maior rede de televisão brasileira.

Pelas questões que suscitam, pelas antipatias, simpatias e admirações, determinados personagens ou modelos da mídia televisiva atingem o público-alvo, provocando ressonância, sedução ou rejeição, de acordo com a proximidade ou distância que mantêm com o observador ou telespectador e com a comparação que este faz com a sua própria vida. Determinadas identificações, em que se juntam e se confrontam os personagens e modelos com o público, dependem das relações, explicações e soluções que refletem e norteiam a vida social do telespectador. Esse personagem amadiano provavelmente passou a ser associado à atriz Sônia Braga como seu modelo, a partir dessa novela, não só pelo seu desempenho como também pelo poder que tem a novela de fazer com que os telespectadores se sintam íntimos dos personagens. No momento em que a novela invade o ambiente familiar e as atenções dos telespectadores se voltam para o vídeo, ela vai criando intimidade com o público e uma ilusão na qual as pessoas se classificam de acordo com as respectivas identificações com os personagens, inclusive aflorando questões e temas diluídos no cotidiano de quem assiste. 
Os personagens, então, como mito, servem de espelho para as relações sociais vividas no cotidiano e, como ritual, põem em relevo certos elementos da vida social que se atualizam na relação personagem-modelo e telespectador.

Assim, torna-se comum que comentários de pessoas pertencentes ao público-alvo de algumas novelas sejam orientados pelo quadro de valores do seu contexto social, apropriando-se dos personagens para pensar a sua própria realidade. Além disso, a partir do momento em que a TV e o livro funcionam como veículos de comunicação, vendem moda, estilos de vida, sensações, emoções, visões de mundo, relações humanas, hierarquias e sistemas de classificações que são reabsorvidos pelo público que os consome e passam a ser referência na vida social. As mitologias publicitárias são baseadas, na sua maioria, em arquétipos, procurando despertar sentimentos associativos no seu consumidor-alvo, resultando, na maioria das vezes, em ícones e/ou em imagens duradouras que fazem parte da cultura, refletindo e reafirmando valores. Segundo Randazzo (1997, p. 100): "[...] todo o material simbólico emana das camadas mais profundas do inconsciente coletivo que nos falam através das imagens arquetíícas". Ou seja, os símbolos do mito são o resultado do trabalho intuitivo e inconsciente da psique humana.

Os arquétipos usados pela mitologia publicitária também moldam a vida das pessoas quando estas são atingidas, não só em nível consciente como também no nível mais profundo, instintivo e emocional. Esse aspecto da mulher bela, fascinante, sedutora, suave e sexualmente atraente, destacado por Amado na sua personagem Gabriela, é reafirmado na novela e na capa dessa edição. É uma das imagens arquetípicas da mestiça no contexto social do público-alvo do livro e da novela. Vários exemplos desse arquétipo podem ser encontrados na literatura, no cinema, nas artes plásticas e na propaganda.

No campo da moda nesse período, na Bahia-Brasil, mulheres com roupas de estampas muito coloridas, decotes pronunciados e cabelos cacheados soltos, reproduzem o modelo encenado por Sônia Braga. Pode-se pensar que estariam repetindo as características do personagem por meio da identificação, ou o personagem foi construído pelos padrões da moda local, para uma perfeita interação modelo e público-alvo. É importante observar a coincidência da introdução desse modelo num contexto marcado por movimentos de libertação feminina que reivindicavam mudanças na posição social da mulher, e uma mulher mestiça é o personagem principal, valorizando positivamente a Bahia. 
Fonseca (2000, p. 104), refletindo sobre as imagens do negro na cultura brasileira, diz: "[... ] o diferente por si só não é suficiente para impedir a circulação de estereótipos depreciativos que induzem os não brancos a se ocultarem em 'simbolismos de fuga' que os situam mais próximos do modelo tido como superior. As variações de cor explicitadas pelo censo de 1980 mostram essa tendência de utilização de mecanismos que procuram esconder a cor real da pele, mas que, ao mesmo tempo, servem para acentuar o grau de intolerância da sociedade brasileira com relação à cor da maioria da sua população".
Como os arquétipos são atualizados na dialogicidade entre o discurso "dito" pelo modelo-personagem e o produzido pelo leitor-observador no contexto histórico-social, o arquétipo encenado por Sônia Braga se ajusta às qualidades positivas das novas situações contextuais. Nas descrições de sua personagem, Amado diz que a Gabriela é uma mulher mestiça, mulata, filha de pais de etnias negra e branca. A mulher baiana, representada por Amado através da mulata Gabriela, possui uma variação na pigmentação da pele entre clara ou negra, com cabelos crespos ou mais soltos, numa variação bastante indefinida, sendo chamada de mulata tanto uma pessoa de pele mais escura como menos escura, mas de cabelos crespos ou ondulados. Há uma série de designações para sua identificação, como parda, sarará, cor de cuia, escurinha, morena clara, morena escura, cabo verde e outras que são usadas, inclusive, pelos próprios indivíduos, a depender da conveniência da situação.

Em virtude de problemas oriundos da colonização e do preconceito racial, a mulher mestiça brasileira procura assemelhar-se ao modelo europeu fisicamente e, com isso, omitir sua origem, não só devido às influências adquiridas pela sua formação e educação em uma cultura branca, como também pela necessidade de sobrevivência em um contexto social preconceituoso e que desqualifica o negro ${ }^{17}$.

É provável que as atrizes escolhidas para encenar o papel de Gabriela nas duas novelas espelhem esse problema: Jeanette Vollu, atriz da primeira novela ( I96 I), era branca de olhos verdes; na segunda novela (1975), Sônia Braga, que já tem o tipo híbrido, para encenar Gabriela, precisou bronzear-se bastante. Isso demonstra o conhecimento dos diretores das novelas sobre o grau de aceitação dessas personagens em relação ao telespectador, como comprova a forte ressonância estabelecida entre Sônia Braga e o público-alvo brasileiro, perpetuando-a como modelo da Gabriela amadiana e de outras personagens, no cinema e na TV, como Dona Flor e Tieta.

Talvez, não tenha sido escolhida uma atriz com a pele muito escura e com cabelos muito crespos, para não correr o risco de o público identificá-la com uma mulher negra, pois o confronto de valores poderia impedir o sucesso da novela, construída em torno da personagem. Por outro lado, os heróis e modelos venerados por um povo são um reflexo dos seus ideais, a mídia apenas os transforma em mercadoria.

Como há uma tendência em parecer real o que aparece na TV a ponto de ser dito, popularmente, que se você aparece na TV você existe, para o público a reprodução da pseudo-realidade é, muitas vezes, mais gratificante do que a própria 
realidade, por isso a imagem se transforma em geradora da realidade. Nesse sentido, os estereótipos são um recurso eficiente porque pressupõem uma simplificação da realidade e uma facilidade de identificação. Os grupos que constroem os discursos para a mídia têm consciência do poder de sugestão e da carga emotiva das imagens, que permitem a penetração inconsciente dos estímulos com forte componente ideológico. Portanto, os autores que pertencem a esses grupos, normalmente reduzem o nível de consistência das informações e as possibilidades de uma percepção reflexiva e crítica, deixando o público-alvo desprotegido das forças do imaginário. Esses grupos se aproveitam dos recursos visuais (o discurso nãoverbal) para produzir sentido, supondo que será assimilado pelo público sem questionamento. Esta é uma forma de vender ideologia, tanto pelo que é dito quanto pelo que é omitido e sutilmente percebido pelo público ${ }^{18}$.

Provavelmente, o modelo criado para a personagem interpretada pela atriz Sônia Braga passou a ser considerado, pela mídia, pela moda e também por parte do público, como tipo não só da Gabriela amadiana, mas, consequentemente, da mulher baiana e, metonimicamente, da brasileira. Explica-se o fato porque a indústria cultural deu um sentido à narrativa amadiana, unindo ideologia e cultura na dinâmica profunda da memória e do imaginário do seu público-alvo. Permitiu-se, com isso, que especialmente as mulheres se reconhecessem nela, como se estivesse, no modelo da personagem construída, o modo de expressão, de viver e de sentir das mulheres baianas. As mulheres, possivelmente, quando assistiram à novela na TV, reconheceram o modelo criado pela mídia como uma mulher baiana, com características semelhantes às suas, e se seus traços pessoais não se assemelhavam aos do modelo, procuraram imitar para se parecerem, cada vez mais, já que estavam seduzidas pela personagem.

Nesse aspecto, não está implícito somente o jogo da mídia que, para divulgar, atinge o inconsciente coletivo, mas também o trabalho de imposição cultural, pois atualiza o preconceito racial, quando não retrata/representa a personagem com características mais próximas das descrições do autor do texto literário. Com essa adaptação, está endossando uma inautenticidade, uma imagem anedótica, mesmo num local onde a sua população é, muitas vezes, mais negra e mestiça. Não podemos deixar de perceber, porém, que existe, no País, uma cultura impregnada de preconceitos e historicamente estocada no imaginário coletivo. Este e outros enfoques preconceituosos podem estar sendo representados pelos implícitos deixados por Amado no seu texto. Fonseca (2000, p. I05), mostrando a ocultação da diferença racial no Brasil, expressa:
18 Segundo Martin-Barbero (1997, p.308): " [...] não é a representação dos fatos concretos e particulares o que produz o sentido de realidade na ficção, mas uma certa generalidade que visa ambos os lados e dá consciência tanto aos fatos particulares do real quanto ao mundo fictício". 
${ }^{19}$ Segundo Compagnon (1999, p.35): "[...] há um conhecimento do mundo e dos homens propiciado pela experiência literária (talvez não apenas por ela, mas principalmente por ela), um conhecimento que só (ou quase só) a experiência literária nos proporciona".
[... na caracterização do personagem-título do romance Gabriela, Cravo e Canela, de Jorge Amado, há uma marcação ditada por estereótipos negativos. Os predicados que fazem dessa personagem a representação da mulata sensual, em sua opinião, também enfatizam os estereótipos da mulata como "fêmea amoral, irresponsável e impudica". Enaltecida como símbolo da mulher genuinamente brasileira, a mulata Gabriela expõe, com sua ingenuidade dengosa, a precariedade moral que a condena, mas ocupa um espaço que se define pela oposição aos ocupados pelas representações de esposa virtuosa e de mulher honrada, ratificadas pela sociedade. O excesso de atributos físicos que tornam a personagem intensamente desejável acaba por fortalecer o estereótipo de mulata sensual, exuberante embora o narrador se prime por investi-la de qualidades que convivem, harmoniosamente, com a beleza dos seus traços agrestes e o cheiro de "cravo e canela", que condimente a atração irresistível que a personagem exerce sobre os homens.

Observa-se, entretanto, que o estereótipo criado pela mídia eletrônica, por meio da novela, difere, em outros aspectos, das descrições de Amado, como comprova um dos seus ilustradores e amigo: "Olha, Gabriela não é isso que as pessoas fazem por aí. Gabriela é uma mulata de cabelo duro, mas ela é dengosa, é roliça"; "[...] parece gordura [...]" (apud TEIXEIRA, 1993, p. I74). O capista trabalha com o estereótipo de beleza da mulher mais magra, imposto pela mídia, que impede que o tipo roliço, que parece gordura, descrito por Amado, seja reproduzido, instalando uma modelização coerente com a cultura dominante.

Esses posicionamentos preconceituosos e racistas são problemáticos, pois tratam de uma estratégia dominante não só de um poder político e econômico, mas também do poder histórico, que vem desde a colonização, reforçado pelas teorias de raça do século XIX, que repercutem até hoje em nossa cultura. Esse apelo à caricatura e a estereótipos acentua a necessidade de repensar o papel da literatura como narrativa que contribui para a construção da identidade brasileira, e as conseqüências dessas descrições ${ }^{19}$.

A estratégia de escolha da atriz, mulher de pele clara e cabelos suavemente ondulados para representar a Gabriela, pode parecer ingênua, mas faz lembrar a noção de equivalência, a aproximação ou recuperação das idéias e significados contidos no texto literário e que deverão ser representados na rotulagem da capa. Essa estratégia inconsciente torna o discurso conflituoso, já que demonstra a formação do povo brasileiro e a sua condição de colonizado, marcado pelos preconceitos, pelo subterfúgio ou pelo silêncio em relação às classes subalternas e de etnias africanas.

Esses discursos legitimam como verdadeiros traços raciais diferenciadores, demarcam lugares para que a sociedade os preserve como um todo e, quanto 
mais repetidos, mais se fortalecem. A relação Ocidente/não-Ocidente, como discurso produzido pelo pensamento europeu, assimilado pela cultura brasileira através da educação e das práticas sociais, se faz presente, até hoje, através de seus discursos, e, como não poderia deixar de ser, se faz presente também em sua literatura ${ }^{20}$.

Esses discursos são assimilados como "verdades", reforçando e familiarizando a forma preconceituosa de aceitação do negro e do mulato na sociedade; um negro caracterizado como branco, sem espaço para assumir seu tipo físico e sempre buscando o ideal de beleza imposto por convenções de linguagens que assumem o lugar de "verdade" nos termos da adequação do "real" à sua representação. Os leitores e espectadores são, assim, forçados a proceder de acordo com a rígida seleção de regras, de modelos e de formas simbólicas que sustentam a identidade do outro, abolindo a dinâmica natural de reconhecimento e interpretação natural do sujeito.

A representação de Gabriela por Sônia Braga, ao mesmo tempo em que desencadeia a prática de ocultamento da intervenção do capista, provoca no observador a sensação de que está diante de uma representação transparente da descrição de Amado.

\footnotetext{
${ }^{20}$ De acordo com Said (1995, p.245): “[...] teremos de levar em conta a persistente disparidade de poder entre o Ocidente e o não-Ocidente, se quisermos entender bem formas culturais como o romance, o discurso etnográfico e histórico, certos tipos de poesia, ópera, formas nas quais abundam alusões a essa disparidade e estruturas nelas baseadas".
} 



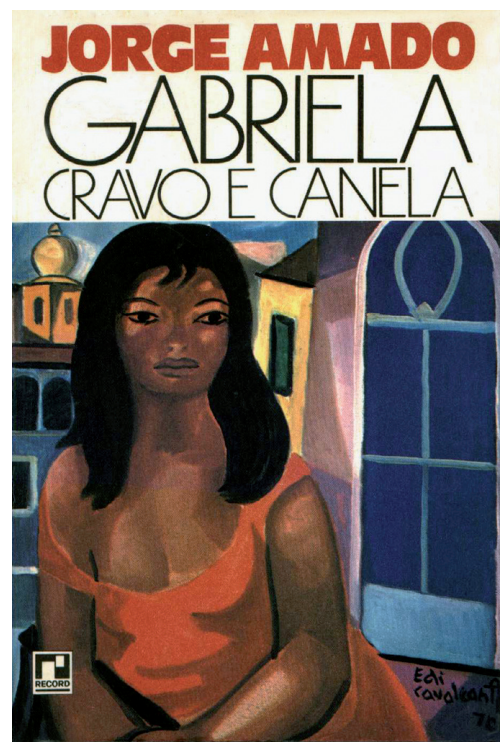

CAPA 6

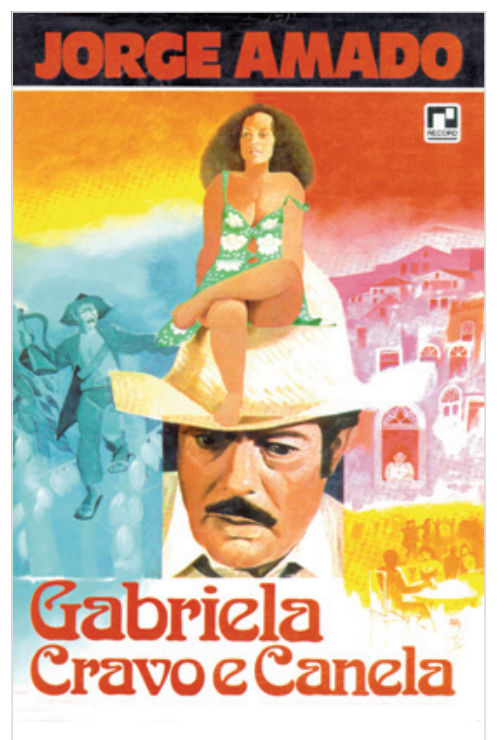

CAPA 7
Sexta e Sétima Capas

Título Gabriela Cravo e Canela País BRAsIL

Editora RECORD

Ano 1982 E 1983

Autoria das capas Sem Referência

Autoria das ilustrações

Di CAVALCANTI - capa 6

FLORIANO TEIXEIRA - capa 7

Técnicas das ilustrações PINTURAs 
${ }^{21}$ Di Cavalcanti é autor, também, da capa da primeira edição estrangeira, a edição francesa de 1959. bservando as condições de produção, percebe-se que a capa de 1982 é de autoria de Di Cavalcanti ${ }^{21}$ e, a partir da tiragem de 1983, passa a ter uma sobrecapa de autoria de Floriano Teixeira, provavelmente para que o consumidor fizesse a ligação com o filme Gabriela, Cravo e Canela, direção de Bruno Barreto, veiculado naquele ano.

Nos dois anos consecutivos (1984, 1985), a ditadura chegava a seu esgotamento com João Batista Figueiredo, também empossado por um colégio eleitoral. Mas já se iniciava no País um movimento que envolvia a sociedade civil, exigindo "Diretas-Já", com muitos comícios em várias cidades, o que contribuiu para o fim do regime militar. Esse movimento de redemocratização não era exclusividade do Brasil, mas espalhava-se por toda a América Latina. A dívida externa brasileira superava os US $\$ 90$ bilhões, os salários dos trabalhadores estavam cada vez mais baixos e, sob a liderança do PT e dos partidos de esquerda, aconteceu uma das maiores manifestações populares na história do Brasil, a campanha pelas eleições diretas.

Abalado por incertezas devido às pressões políticas que ocasionaram o fim do regime militar, a diminuição da censura e a crise da economia, o cinema nacional passa a abordar as questões nacionais e o erotismo. A pornochanchada afirmava-se no cinema nacional. Foram sete anos (1980 a 1987) em que muitos dos filmes brasileiros podem ser englobados sob o rótulo de "eróticos, como: Coisas eróticas, com a direção de Rafaele Rossi, Rebuceteiro, de Claudio Cunha, Estranho Desejo, de Jean Garret. Nesse período, o cinema brasileiro prossegue as suas exibições, contornando a censura com mandatos judiciais em sua defesa e diversificando os temas, mas com a imaginação pornográfica correndo solta e veloz. Os filmes nacionais pornôs explícitos, juntamente com a entrada dos pornôs estrangeiros no circuito exibidor, ocuparam vasta fatia do mercado brasileiro. Nos anos 1982 e 1983, também foi encenada uma série de filmes abordando questões 
políticas, questionando os equívocos do passado e o peso da tradição, como Os Chapeleiros, de Adrian Cooper, Nunca fomos tão felizes, de Murilo Salles, e Extremos do prazer, de Carlos Reichembach. Em meio a esse clima, o cinema brasileiro tinha acabado de perder um dos seus cineastas de vanguarda, Glauber Rocha, e a L. C. Barreto Produções lançava no mercado brasileiro, sob a direção de Bruno Barreto, o filme Gabriela, Cravo e Canela, baseado no romance de Jorge Amado, tendo como protagonistas a brasileira Sônia Braga e o italiano Marcello Mastroiani. Esse lançamento ocorreu em momento oportuno, depois do sucesso de público da novela, estrelada pela atriz e Armando Bogus. O filme vinha inserir-se no conjunto de filmes do momento, uns com contornos gradativamente mais ousados, destacando a nudez das atrizes e o domínio do sexo explícito, e outros com abordagens políticas. Também já estava sendo ensaiado, nessa época, o balé "Gabriela", com coreografia de Gilberto Mota, música de Edu Lobo e figurino de Carybé, que estreou em 1983.

O mundo estava às vésperas de grandes transformações no campo do comportamento humano. A descoberta do vírus da Aids, transmitida principalmente por meio da relação sexual, fez surgir uma nova onda de moralismo, levando muitos pregadores religiosos a advertirem que a doença era um castigo de Deus contra a promiscuidade. No campo político, os argentinos passaram a ocupar as Illhas Malvinas, desencadeando uma guerra. No Líbano, os milicianos de direita cristã chacinavam cerca de mil palestinos e o movimento pacifista "Paz Agora" colocou nas ruas milhares de pessoas contra a invasão do Líbano, resultando na retirada dos milicianos e no início de grandes transformações políticas no Oriente Médio. Enquanto isso, os Estados Unidos invadiam a ilha de Granada, alegando proteger a população americana ali residente. Por fim, o filme E. T., direção de Spielberg, batia recordes de público, tornando-se o maior sucesso na história mundial.

A capa do ano de 1982 foi ilustrada por Di Cavalcanti, artista plástico e pintor. Emiliano Augusto Cavalcanti de Albuquerque Melo nasceu em 1897 no Rio de Janeiro. Ainda menino, conheceu, na casa de seu tio José do Patrocínio, intelectuais e artistas como Olavo Bilac e o pintor Puga Garcia. A publicação de um dos seus desenhos na revista Fon Fon, no ano de 19|4, marcou o início de uma série de colaborações na imprensa. Di Cavalcanti, dois anos depois da publicação desses seus desenhos, tomou parte no Salão dos Humoristas, organizado por Luís de Peixoto e Olegário Mariano. No mesmo ano, matriculou-se na Faculdade 
22 Sobre esta exposição, Mário de Andrade escreveu: "Di Cavalcanti conquistou uma posição única em nossa pintura contemporânea. Em nossa pintura brasileira. Sem se prender em nenhuma tese nacionalista, é o mais exato pintor das coisas nacionais. Não confundiu Brasil com paisagens; e em vez do Pão de Açúcar nos dá sambas, em vez de coqueiros, mulatas, pretos, e carnavais. Analista do Rio de Janeiro noturno, satirizador odioso e pragmatista das nossas taras sociais, amoroso cantador das nossas festinhas, mulatistamor da pintura, este é o Di Cavalcanti de agora, mais permanente e completado, que depois de onze anos vai nos mostrando de novo o que é". ( verbete Arte no Brasil, 1979, p.682). de Direito e passou a trabalhar no jornal O Estado de São Paulo como revisor. Foi em 1917 que realizou sua primeira mostra individual, como desenhista numa editora de livros. $\bigcirc$ escritor Mário de Andrade costumava dizer que ele era "o menestrel dos tons velados", pois utilizava como meio de expressão o pastel, evocando figuras femininas. Em 1921, realizou sua primeira exposição de pinturas e, no ano seguinte, participou da Semana de Arte Moderna. Alguns autores suspeitavam que a Semana de Arte Moderna de 1922 tinha sido originada de uma sugestão de Di Cavalcanti e de Paulo Prado. Di Cavalcanti participou desse evento com muitos trabalhos, recebendo uma crítica negativa feroz de Pauci Vero Electo (veiculada na Gazeta do dia 22 de fevereiro de 1922), segundo a qual seus trabaIhos não deveriam nem ser considerados. Depois, o pintor interrompe o curso de Direito e resolve dedicar-se às Artes Plásticas. Em 1923, embarcou para a França, tornando-se correspondente do jornal Correio da Manhã até o seu fechamento no ano de 1924. Cursou a Academia Ranson e fez muitos amigos, entre eles, os poetas Jean Coqteau e Blaise Cendrars, os pintores Picasso, Braque, Léger e Matisse e o compositor Eric Satie. Expôs em Bruxelas, Londres, Amsterdã, Berlim, Lisboa e Paris.

Nessa época, Sérgio Milliet referia-se a Di Cavalcanti como o primeiro brasileiro a transpor a influência de Picasso para o âmbito brasileiro. Ao retornar ao Rio de Janeiro, executou dois painéis, em 1929, no Teatro João Caetano, como também apresentou nova mostra de arte. Em 1932, expôs individualmente em São Paulo22.

Entre 1935 e 1940, residiu em Paris, já em companhia da esposa Noêmia Mourão. Ao começar a guerra, volta ao Brasil, utilizando como temática para sua pintura: mulatas, carnaval, negros, vielas escusas, paisagens dos trópicos, interiores de cabaré, naturezas mortas e poucas cenas religiosas. Na década de 40, tornou-se um dos mais notáveis pintores brasileiros. Em 1951, a convite, participou da I Bienal de São Paulo, recebendo na Bienal seguinte o prêmio de Melhor Pintor Nacional. O mesmo certame consagrou-lhe uma sala especial em 1963, organizada por Luis Martins.

Em 1954, O Museu de Arte Moderna do Rio de Janeiro realizou a primeira retrospectiva de sua obra, mas a retrospectiva completa ocorreria em 1973, no Museu de Arte Moderna de São Paulo, com centenas de obras. Em 1959, ilustra a capa do romance Gabriela, Cravo e Canela, da editora francesa Seghers L'inter. Di Cavalcanti escreveu vários livros de memórias e se destacou como ilustrador 
de numerosos livros tais como: Losango Cáqui, de Mário de Andrade; Noite na Taberna, de Álvares de Azevedo; e Gabriela Cravo e Canela, de Jorge Amado. A mulata foi sua marca inconfundível23.

Ocupa um lugar importante no panorama da pintura moderna brasileira pelo realce de sua participação histórica e pelo alto nível de sua contribuição artística, sendo um dos primeiros artistas brasileiros a reconhecer a necessidade de uma pintura reveladora da "verdadeira" história brasileira, apagada por razões políticas que produzem um discurso sobre cultura que resulta em "exotismo" e apontam os brasileiros como seres culturais singulares, a-históricos.

A sobrecapa da edição de 1983 é de autoria de Floriano Teixeira, artista plástico que nasceu no Maranhão em 1913. Depois de uma passagem marcante pelo Ceará, passou a morar na Bahia em 1965, a convite do amigo Jorge Amado. $A$ arte de Floriano ganhou maior visibilidade nacional e internacional devido às várias ilustrações dos livros de Amado, Dona Flor e seus dois maridos, A morte e a morte de Quincas Berro D’Água, Os velhos marinheiros, O menino grapiúna e Tocaia grande.

Ao longo da sua carreira, passou por diversas técnicas artísticas, criando do figurativo ao abstrato. Essencialmente um desenhista, considerava o abstracionismo muito exigente, por isso tinha uma idéia muito clara acerca da representação da imagem. Era consciente da importância de sua obra para as gerações mais jovens. Fez várias exposições dos seus trabalhos, destacando-se a participação na Exposição de Artistas Ibero-americanos de promoção da UNESCO em Madri, Espanha, na qual somente a sua obra e a de Carybé foram as únicas representantes do Brasil. Era considerado pela crítica como um autor de um traço artístico inconfundível pelo lirismo e pela sensualidade e leveza. Alguns dos seus trabalhos destacavam-se pela figura feminina e cenas de sexo sem perder a suavidade e elegância.

Faleceu no ano 2000, deixando uma carreira de 60 anos de trabalhos marcados pela versatilidade de estilos e técnicas.

Na primeira capa percebe-se no centro ótico, local de maior atração visual, a reprodução da pintura de Di Cavalcanti, "Gabriela" 1970, chamada "Gabriela", feita para a coleção Pirelli, elaborada para o calendário de 197I, Bahia de Jorge Amado. O gráico da diagramação indica uma forma que lembra cobertura, como na sobrecapa da edição brasileira do ano de 1975. As fontes usadas na impressão do nome do autor demonstram força pela grossura das hastes, enquanto, na impressão do nome do romance, a fonte sugere leveza pelo traço fino e arredondado.

\footnotetext{
${ }^{23}$ Di Cavalcanti afirma: "A mulata para mim, é um símbolo do Brasil. Ela não é preta, nem branca. Nem rica, nem pobre. Gosta de dança, gosta de música, gosta de futebol como o nosso povo. Imagino-a deitada em cama pobre como imagino o país deitado em berço esplêndido". (verbete Arte o Brasil, 1979, p.684).
} 
${ }^{24}$ Marcello Mastroianni, ator italiano de cinema, nasceu em 1924, iniciou a carreira no teatro, destacando-se pela atuação no cinema internacional, especialmente no filme A doce vida, de Frederico Fellini. Faleceu em 1996.
No discurso de Di Cavalcanti, a pintura da figura feminina é morena escura, com cabelos negros, corpo robusto, braços fortes e roliços, com vestido vermeIho bastante decotado e com parte do seio à mostra, olhando para o observador e sentada à frente de um casario. $\bigcirc$ rosto tem olhos negros, nariz pequeno e lábios grossos. Esta figura feminina aproxima-se, fisicamente, das mulatas, mestiças, dos quadros do pintor carioca.

As mulatas de Di Cavalcanti também possuem o ar de sensualidade como o da personagem amadiana. A sensualidade, nessa ilustração, é passada pela cor do vestido, pois, de acordo com Pedrosa (1982, p. I08), "[...] o vermelho representa a libido, o coração, o calor, a paixão ardente" e atrai a atenção do espectador por ser mais impactual, como na quinta capa.

Nessa pintura, a posição do corpo e o olhar da figura feminina têm a expressão de uma mulher a corresponder ao olhar do observador que imagina que a estivesse olhando, e a esse olhar oferecesse a sua feminilidade. A figura em repouso está carregada de energia, a qual é impulsionada na direção do seu olhar. A imagem da mulher é uma presença forte, e será analisada segundo as convenções da aparência social da mulher. A aparência manifesta-se nas expressões, por isso a mulher costuma tomar conta de si permanentemente e estar acompanhada pela imagem que tem de si mesma. A mulher acaba por considerar-se vigilante e vigiada, dois elementos constitutivos, embora diferentes, da identidade da mulher. Nesse sentido, Berger (1972, p.5I) afirma sobre a mulher:

Tem de vigiar tudo que é, e tudo o que faz, pois a sua aparência, em primeiro lugar, a sua aparência perante os homens é de importância decisiva para o que poderá ser geralmente, o seu êxito na vida. O seu próprio sentido daquilo que é, é suplantado pelo sentido de ser apreciada como tal, por outro.

Sendo assim, esse modelo de Gabriela também reitera a personagem como mulher sedutora e atraente.

Atrás da figura feminina, há um casario representativo do cenário da época do romance, em tons pastéis, com uma casa em verde e amarelo, cores da bandeira nacional, e uma janela em plano maior, fechada, em tons de azul, dando a ilusão de profundidade. Desse modo, a janela que sinaliza para uma saída é considerada como possibilidade de visão do espaço interno, mas, estando fechada e com a cor azul, deixa a visão interna a cargo da fantasia e do inconsciente do espectador. Relacionando-se com a história do romance, a janela passa a ter uma 
forte ligação com a vida, já que algumas personagens viviam presas e tinham a janela como única ligação com o mundo lá fora, a vida de llhéus, como a personagem Glória representada na capa do ano de 1958. Como a Gabriela está fora da janela, subtendeu-se que ela não precisa da janela para se comunicar e interagir como as outras mulheres.

Logo após a visão do quadro de Di Cavalcanti, que também funciona como uma janela para o observador da capa em razão do formato, percebe-se, sobre ele, no canto inferior direito, a marca da editora. Em ritmo ascendente, acima, o nome do romance na cor preta, e, sobre este, o nome do autor na cor vermelha, numa tipologia (formato "bold") de tamanho maior que a fonte que imprime o nome do romance, destacando-se, portanto, na diagramação da capa. Os enfoques escolhidos para representar a obra literária nessas capa e sobrecapa continuam sendo a mulher, mas de forma diferente das abordagens das capas do ano de 1975. Nas edições anteriores, as mulheres são representadas com certo recato, com certa censura, em relação às abordagens de 1982 e 1983, em que a mulher aparece mais provocante, com partes do corpo à mostra, insinuante e em posição erótica. É provável que essas representações tenham sido escolhidas, diante do afrouxamento da censura, do sucesso das pornochanchadas e do erotismo da mulher, mantido constantemente nos veículos de comunicação.

Na quarta capa, dessa edição, está impressa apenas uma foto de Amado feita por Zélia Gattai, sua esposa, exatamente no tamanho do formato da capa. Essa foto é um close do rosto do escritor olhando para o lado, como se estivesse visualizando algo do seu interesse quando foi fotografado.

Na sobrecapa, a ilustração mostra, no centro óptico, o retrato do ator Marcello Mastroianni ${ }^{24}$, que no filme, adaptado do romance, encenou o personagem Nacib. Em atitude séria, com o olhar voltado para baixo, como se estivesse pensativo, de chapéu. Sentada sobre o seu chapéu, está Gabriela representada pela atriz Sônia Braga ${ }^{25}$.

No fundo, atrás da imagem do Nacib, percebe-se a representação de três cenas num intenso colorido. Abaixo dessa imagem, a diagramação mostra o título do romance em tipologia de destaque, na cor vermelha, e, acima de toda a representação, a marca da editora Record e o nome do autor, em letras vermelhas sobre fundo preto. $\bigcirc$ gráico imposto pelo diagramador revela movimento na parte baixa e uma seta para o alto indicando o nome do autor, com estabilidade e firmeza. As fontes demonstram força, estabilidade, pelas serifas e hastes grossas, e o arredondamento, harmonia e movimento.
${ }^{25}$ Sônia Braga, atriz brasileira, destacou-se pela atuação no cinema, representando os personagens amadianos Dona Flor, do romance Dona Flor e seus dois maridos, e Gabriela, do romance Gabriela, Cravo e Canela. 
${ }^{26}$ Como afirma Pease (1995, p. I 37): "Com o joelho exposto, uma perna colocada sob a outra, apontando para a pessoa que ela acha interessante. Estaé uma posição relaxante, que tira a formalidade da conversa e proporciona oportunidade para uma rápida exposição das coxas. A maioria dos homens concorda que a perna entrelaçada é a posição feminina de sentar mais sedutora. É um gesto que as mulheres conscientemente usam para atrair a atenção".
Já na quarta capa, foram impressas três fotografias das cenas do filme, tendo ao lado o nome Gabriela na mesma fonte usada no título. Abaixo das fotos, a ficha técnica do filme Gabriela Cravo e Canela, direção de Bruno Barreto e produzido pela L. C. Barreto Produções, que estreou no Brasil no mesmo ano da confecção da capa (1983).

rosto de homem, na primeira capa, está representado com bigodes e costeletas longas, a gola da camisa branca está aberta, com nó da gravata folgado, sob paletó em tonalidade creme claro, com chapéu na cor e textura da palha. Essa representação lembra o personagem amadiano Nacib, encenado por Mastroianni, assim como a mulher, que Floriano Teixeira representa de cabelos castanhos cacheados e soltos, sentada no chapéu de Nacib, retrata a Gabriela, encenada por Sônia Braga.

Na capa, ela está com vestido estampado, de decote pronunciado, mostrando parte do seio, descalça e com pernas cruzadas, deixando ver as coxas, numa cena provocante. Essa posição insinuante, proporcionando a exposição das coxas tem um efeito erótico para o observador. Na cinésica, essa posição é considerada por alguns autores, como sedutora. Também usada pelas mulheres idealizadas pelo código masculino como comportamento para atrair a atenção dos homens ${ }^{26}$.

Essa representação lembra como o personagem Nacib vê a Gabriela, no texto amadiano, por isso representado por Teixeira como se estivesse em sua cabeça. No fundo dessa imagem, ao lado da representação de Nacib, três cenas também aludem ao texto amadiano: em tom azul, a representação de um jagunço como se estivesse em movimento, andando com braços abertos, sem camisa, com um rifle nas mãos, em meio a uma plantação de cacau que, pela cor usada, sugere um ambiente sombrio, o anoitecer. Parece o momento, na trama do romance, em que o jagunço avisa a morte do intendente para a população da cidade; nos tons magenta e amarelo, há duas cenas como se fossem a representação do reflexo do pôr ou do nascer do sol e a representação de um casario, em magenta, com uma mulher na janela, lembrando a personagem amadiana Glória; em tom amarelo, a representação de uma mesa de cabaré, provavelmente o Bataclan, citado por Amado, no qual as mulheres se apresentavam com roupas bastante decotadas, como mostra a ilustração, e se encontravam com os homens nas noites ilheenses.

No fundo da imagem da Gabriela, o artista utiliza as cores do céu durante o crepúsculo, vermelho e amarelo, e, em meio a estas cores, a imagem da Gabriela 
surge como um sol, provavelmente lembrando a importância e a alegria provocada por essa mulher na vida do personagem Nacib. Acima, em preto e branco, a marca da Editora Record, em grande contraste com o fundo na cor vermelha. Abaixo da pintura de Teixeira, o diagramador imprimiu o título que está em destaque, assim como o nome de Amado, deixando ver que ambos têm importâncias relevantes no mercado editorial, já em contraste com o ocorrido nas capas anteriores ao ano de 1975.

Na quarta capa, o diagramador distribui três fotos, em parte sobrepostas, de três cenas do filme: uma de Nacib, pensativo, vestido com uma camisa listrada de mangas compridas, com a mão no queixo e junto à caixa registradora do bar Vesúvio; na outra fotografia, está a personagem Gabriela sentada na cama, encostada na cabeceira, ao lado de uma pequena mesa com abajur e jarro com flores. Parece estar vestida de camisola, com os cabelos soltos, e encolhida, como se estivesse triste ou pensativa. A terceira foto mostra a Gabriela alegre, com o tabuleiro de quitutes no bar de Nacib, junto a dois admiradores sorridentes, um deles cumprimentando-a com o chapéu e, ao mesmo tempo, colocando uma flor em seu decote. Essas fotos demonstram as duas fases na vida da Gabriela: alegre, quando servia a Nacib, e triste, quando passa a ser sua esposa.

Logo abaixo, está a ficha técnica do filme, legitimando essas representações da capa. Essas três fotos demonstram o cuidado de Nacib com os negócios e com as finanças, e ainda dois aspectos contrastantes da Gabriela: a timidez e a insegurança, que a postura defensiva deixa transparecer, usando as pernas e os braços como barreiras de proteção, e a alegria e desenvoltura diante dos seus admiradores.

Na orelha da capa, encontramos o texto "Gabriela, Cravo e Canela", que é a união dos vários textos das edições anteriores, apenas com algumas modificações. A forma de organização de suas idéias e o tipo de linguagem empregada demonstram que é um discurso estratégico feito para seduzir. É comum que as editoras contratem críticos para escreverem sobre as obras que irão editar, e coloquem esses textos nas contracapas ou nas orelhas dos livros, para imprimir ao discurso mais autoridade, massificando juízos e opiniões, como nas edições anteriores. Mas não se pode deixar de considerar que os textos impressos nessas capas podem ter sido escritos por jornalistas que utilizaram as considerações críticas de outros profissionais. Esse texto demonstra ser uma colagem de vários textos já publicados em outras edições brasileiras. 
locutor que fala, nesse texto, deixa em seu discurso características da posição em que se coloca, construindo análises globalizantes, que apontam para descrições totalizantes.

Só se fala do que se conhece, e o discurso crítico, ao ficar entre a obra e o público, é dotado de duas competências básicas: saber ver e saber falar. Sob a condição de saber falar, o crítico apresenta ao leitor-leigo as qualidades que identificam o objeto-produto. $\bigcirc$ sujeito do discurso argumenta para convencer o leitor da verdade do que diz, ocultando-se na imparcialidade das apreciações. Assegura o valor estético da obra, para produzir seu valor de mercado.

A crítica institui a novidade e a experimentação como critérios de julgamento, em substituição aos tradicionais padrões de beleza e harmonia, e procura estimular o leitor a reflexões, por meio do jogo intrigante do dito e do não-dito no seu discurso. O leitor, e também observador do discurso da capa, por sua vez, aceita a crítica quando a insere numa geração, movimento ou tendência. $\bigcirc$ leitor usa a inserção na contemporaneidade como traço de aceitação. Esse jogo discursivo, às vezes, versa sobre a oposição entre as qualidades internas da obra e o seu valor de mercado, incluindo aí o gosto da época e as exigências do público consumidor, como se percebe no texto impresso na orelha da capa 6:

E o comovente e pitoresco romance de amor do árabe Nacib e da mulata Gabriela coloca-os, sem dúvida, na galeria dos amantes célebres da história.

Gabriela, Cravo e Canela, motivo de orgulho para a literatura brasileira, foi traduzido para I 5 idiomas estrangeiros, em edições que experimentaram enorme sucesso de crítica e de público.

Portanto, no discurso crítico, podem ser percebidos julgamentos pouco fundamentados e fluidez nos critérios de apreciação. Assim, os melhores artistas podem ser não só os que escrevem bem, mas também os que mais vendem. Há, então, uma opção pela ambiguidade: separa-se a avaliação mercadológica do padrão estético, para, em seguida, justificar-se o segundo com as regras da primeira. A aceitação de mercados e dos círculos geradores de prestígios passa a ser o critério que referenda o valor estético da obra literária. Daí ser importante, para a editora, ressaltar a aceitação da obra no mercado local, citando o número de edições e afirmando que o romance é um dos mais vendidos, pois este jogo do mercado é tão forte que penetra na substância das obras, tornando-se lei estrutural para o consumidor e para a mídia. 
O prestígio no circuito comercial torna-se elemento definidor do valor da obra literária, assegura ao artista um lugar de destaque e indica ao leitor a segurança no investimento. É assim que um bom produto passa a superar uma boa obra de arte. Uma obra literária que vende muito, pode passar, muitas vezes, a ter um valor maior do que uma obra literária de excelente qualidade intelectual. Há uma oposição entre especulação, mercado, preços e criatividade, talento e qualidade profissionais que se misturam quando a obra literária torna-se um produto comercial. Nos livros de Amado há, sempre, discursos críticos que valorizam, elogiam e qualificam a obra literária e, ao mesmo tempo, indicam os altos índices de venda, para, mediante esse jogo de mercado, comprovar a avaliação crítica e garantir a venda do romance.

Os agentes mercadológicos tanto podem produzir valorizações irreais, privilegiando valores exteriores à obra literária, como valorizações reais e justas baseadas nas qualidades internas da obra, como objeto de arte. O crítico pode utilizar-se do seu discurso para orientar a leitura do observador leigo, oferecendo-lhe um olhar esclarecido e mais atento, por estar ciente do seu papel de formador de opinião, assim como produzir valores distantes da realidade. No momento em que o leitor assimila o discurso do crítico, sente-se competente para investir no produto, sem se dar conta da consciência ideológica do sujeito que construiu o texto. No texto "Gabriela, Cravo e Canela", os dois primeiros parágrafos informam sobre a obra literária e suas qualidades, e o terceiro versa sobre o produtolivro e seus efeitos no mercado.

O sujeito da enunciação se coloca na $3^{\text {a }}$ pessoa, como na maioria dos textos das capas brasileiras, e comunica-se com o enunciatário por meio da dissimulação de um padrão jornalístico que, ao mesmo tempo em que afirma como autoridade, no discurso da capa, adequa-se à expectativa de um consumidor idealizado pelos mecanismos da propaganda. O objetivo desse enunciador é tornar o discurso imparcial como se os fatos fossem narrados por si. São fatos de domínio público, todos sabem que aconteceram, não há o que contestar. Por isso apaga as marcas que o identifiquem como produtor da enunciação, apresentando o seu pensamento sob a forma de definição: "O livro é a crônica [...]"; "Jorge Amado é escritor". $\bigcirc$ enunciador caracteriza o seu saber e, ao mesmo tempo, reforça o sentido de verdade do seu discurso, cristalizando assim uma das tendências do discurso crítico: tornar objetiva uma apreciação que envolve, além de um conhecimento técnico, o gosto e a emoção, colocando a objetividade sem ser tendenciosa, e a subjetividade sem apagar a emotividade de uma apreciação estética. 
Já o consumidor, ao fazer a leitura do texto, provavelmente, sente-se tentado a participar das colocações feitas pelo olhar do crítico, e contempla a obra literária conforme a visão positiva do crítico enunciador. Como leitor-enunciatário, poderá revestir-se do papel de especialista se acatar a orientação do sujeitoenunciador e tornar-se um possível investidor, a partir do momento em que toma o conhecimento do saber especializado oferecido e se reconhece dependente dessa interpretação.

Nesse texto ("Gabriela, Cravo e Canela"), os adjetivos também são "pistas" que marcam as posições e incursões revestidas de um julgamento avaliativo. Estas podem camuflar a existência de um sujeito, que toma posição sem se caracterizar como fonte de julgamento. Como exemplos, registram-se: "inigualável lirismo", "qualidades deliciosas", "amantes célebres", "mulher típica", e outros. São juízos de valor que, na leitura, podem passar muitas vezes despercebidos pelos consumidores. A distância do sujeito enunciador e sua ocultação, dizendo sem dizer, constituem um elemento persuasivo que atrai o enunciatário e o aproxima do discurso como se aquela voz fosse a dele, porque voz de quem sabe, conhece e está para opinar, como nas expressões: "sucesso de crítica e de público," e "um dos maiores êxitos".

Há algumas emoções, no texto, que são passadas através das variações das formas verbais e do uso dos advérbios. Esse discurso crítico é introduzido com o verbo no futuro do presente, com a função de prever reações. $O$ narrador se comporta como um sujeito que atesta sua capacidade por meio de um conhecimento que the permite fazer previsões e continua o seu discurso num tempozero, ou seja, sem perspectivas. Mistura o tempo narrado e comentado no mesmo texto. No tempo comentado, usa o presente do indicativo e, no tempo narrado, o pretérito imperfeito e o perfeito; segue alternando o tempo presente com o tempo mais-que-perfeito, assinalando sempre a retrospectiva. Esse jogo dos tempos verbais, em que o uso do tempo do mundo comentado penetra e se mistura com o tempo do mundo narrado, significa menor comprometimento, distância, irrealidade e até cortesia: "Jorge Amado transmite", "O livro é", "[...] quando passava", "Uma adaptação em novela registrou", "[...] quando a novela em capítulos foi mostrada". Esses trechos demonstram uma ação que afirma a posição do narrador diante dos fatos, e, no mesmo parágrafo, narra o acontecido.

$\mathrm{Na}$ retórica da argumentação, um texto opinativo pode, ao afirmar, ocultar efeitos de sentidos, pela explicitação ou apagamento das marcas do enunciador no 
discurso. A intenção é gerar um fazer no leitor, que poderá ser: fazer crer ou fazer-fazer, e são essas instâncias dos fazeres - persuasivo e interpretativo - que criam o convencimento e a adesão necessários à produção e à recepção dos textos como objetos de sentido. São, portanto, acordos entre os sujeitos com base em valores partilhados.

Esse discurso também pretende convencer o leitor da validade das razões apresentadas, para construir o valor da obra literária, por isso o sujeito-enunciador arrola "fatos", "verdades", "previsões" que configuram o seu saber, como: "O livro é a crônica de uma pequena cidade baiana, Ilhéus"; "Gabriela ficará na literatura como uma famosa figura de mulher".

A valorização da obra é construída, portanto, do saber qualificado de quem produz, do crítico e de quem a vê e de quem a seleciona e compra. Como fazer crer - convencer e fazer-fazer - persuadir, não se consegue facilmente, nem com rigidez, pois é a condição da ação pretendida, é necessário juntar os receptores da comunicação (todos os possíveis observadores da capa) com o público-alvo (leitores interessados em literatura ou em obras de Amado) na construção do discurso. Essa junção é facilitada na mistura do estilo crítico e jornalístico quando estes dois tipos de discursos estabelecem a identidade de interesses e a distribuição de papéis que levarão o crítico a produzir o argumento de autoridade, para seduzir a maioria dos receptores.

Como a argumentação vai-se fundamentar nos próprios enunciados da língua constitutivos de sentido, a argumentação deve ser universal, ou seja, ter um princípio comum a uma comunidade, ser geral, isto é, o princípio deve ser considerado válido por todos, e ser gradual, ocorrer em gradações, percorrendo escalas para chegar ao objetivo. A argumentação tem marcas próprias e é encontrada na estrutura do enunciado, inscrita na própria língua.

Ainda nesse texto, são encontrados alguns operadores argumentativos, que indicam conexão ("e"), lugar ("acima"), inclusão ("também"), todos funcionando com o papel fundamental de encadear o discurso ou com o objetivo de apontar para as conclusões orientadas pelos enunciados, como nas expressões: “... uma famosa figura de mulher acima do bem e do mal"; "Foi também adaptada para a história em quadrinhos". Quanto às modalizações dos enunciados, também são organizadas sempre no sentido da assertividade ou afirmação.

A seleção de palavras, silenciando outras, aponta para implícitos, razões da predileção do crítico. Criticar é uma forma de censurar, não tanto pelo que informa, 
mas também por aquilo que deixa de dizer e pelo critério de escolha, que se configura em dizer isto e não aquilo, de forma a direcionar a compreensão do leitor para a desejada pelo locutor. Quando o locutor de um texto faz a opção pela crítica, usa, na maioria das vezes, a autoridade para conquistar, alterna posições de superioridade e inferioridade e neutraliza o discurso numa igualdade, convertendo a submissão em parceria e o autoritarismo em sedução.

Como se estivesse completando todo esse discurso jornalístico e crítico, na orelha da contracapa, a editora imprime os títulos de vinte e sete obras de Jorge Amado, o que, ao mesmo tempo em que divulga, confirma a capacidade profissional do escritor e as afirmações do texto anterior.

Na sobrecapa, além dos títulos, apenas está impressa na quarta capa a ficha técnica do filme Gabriela, Cravo e Canela, com os responsáveis por cada etapa da produção. Essa informação está colocada abaixo das fotos das três cenas do filme, para reforçar a credibilidade das imagens.

Uma ilustração feita por Di Cavalcanti foi a escolha feita pela Editora Record, para a capa desse romance, demonstrando uma estratégia comum no marketing de parceria com um ilustrador que já se destacava no meio artístico nacional e internacional. Dessa forma, a editora trouxe para a capa uma ilustração já veiculada no Calendário Pirelli, provavelmente porque esta pintura demonstra uma insinuação de erotismo numa organização estética bastante sedutora, que estava de acordo com a tendência das mulheres, no cinema e na mídia, naquele momento.

A escolha da editora, mais uma vez, foi feita dentro das características e da padronização usadas pelas publicações naquele contexto. Tratando-se de uma ilustração que representa uma obra de arte de um reconhecido pintor, a forma como será observada estará condicionada aos pressupostos adquiridos sobre o que é arte e, consequentemente, já estarão presentes: beleza, verdade, genialidade, criatividade e outros conhecimentos que podem vir a mistificar a capa.

Essa mistificação pode levar o observador a ver a ilustração com certa emoção, provocada pela contemplação de uma obra de arte, uma representação maravilhosamente elaborada, o que imediatamente valorizaria a capa do romance.

A capa feita por Floriano Teixeira demonstra a ousadia, não só do tema do romance amadiano, como também dos filmes e das publicações que divulgavam as produções cinematográficas no Brasil naquele período. Uma grande quantidade de filmes, exibidos em 1982 e 1983, apresentava contornos mais ousados, sendo rotulados de "eróticos" e, além disso, o próprio filme baseado nesse romance 
já apresentava nudez de alguns atores e cenas de sexo não simuladas. No estilo da maioria dos filmes da época, a capa do livro segue a linha de divulgação que chamava a atenção do público naquele período, ajudando, junto com o filme, a driblar uma censura que já dava sinais de recuo.

Percebe-se, ainda, que esta sobrecapa não deve ter sido feita apenas para proteger a capa anterior como é costume em algumas edições luxuosas. Seria mais uma estratégia de marketing da editora para vender os livros da edição do ano anterior ao lançamento do filme que, provavelmente, ainda estavam nas livrarias. Com esta nova capa, a editora daria notoriedade ao romance, fazendo com que o leitor fizesse a ligação imediata com o filme que estava em cartaz, interessando-se em adquiri-lo, para ter um "pedacinho" do filme e dos seus atores em sua casa, mediante a troca na ação mercantilizada. 



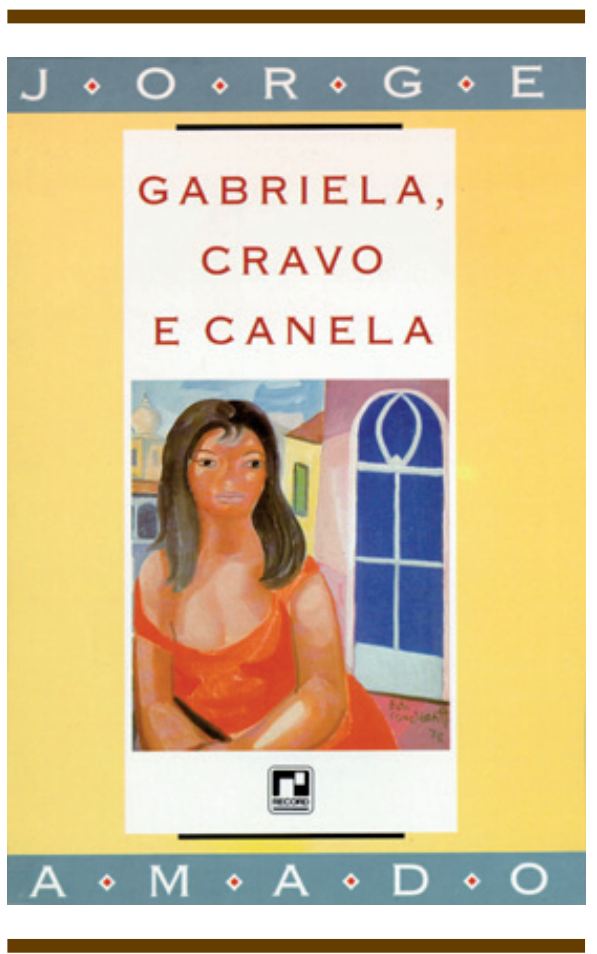

Oitava Capa

Título Gabriela, Cravo e Canela

País BRASIL

Editora RECORD

Ano 1995

Autoria da capa Sem Referência

Autoria da llustração Dı CAVAlCANTI

Técnica a ilustração PINTURA 


\begin{abstract}
A s condições de produção dessa edição indicam que foi lançada no ano de 1995. Governava o Brasil, o presidente Fernando Henrique Cardoso, eleito em 1994. O Plano Real, plano econômico implantado anos antes, conseguiu diminuir a inflação, porém com perda de crescimento, fato despercebido pela sociedade naquele momento. A chegada do presidente F. H. Cardoso ao governo foi marcada por um clima de esperança e ânimo. No período anterior, houve confisco econômico da poupança da classe média, empobrecimento e aumento das desigualdades e desemprego. $\bigcirc$ governo Collor de Mello culminou no impeachment do presidente, e alguns críticos consideravam que, voluntariamente ou não, a Rede Globo de Televisão, um dos veículos de maior audiência do Brasil, incentivou as manifestações a favor do impeachment através da minissérie Anos rebeldes. Veiculada nesse período, a obra retratava as insatisfações e o comportamento da geração brasileira de 1968, com participações em greves e passeatas em repúdio à censura e às atitudes do governo militar.

O governo do vice-presidente Itamar Franco, que substituiu Collor de Mello por dois anos, ocorreu sem muitas mudanças na situação do País, exceto o projeto de transição do Real, criando um clima de expectativa com relação ao próximo governo. $\bigcirc$ Brasil, também naquele momento, tinha acabado de ser tetracampeão mundial de futebol, na final da Copa do Mundo nos Estados Unidos, levando o País a um clima de euforia. Falava-se a todo instante em globalização apesar da desigualdade social, e a sociedade de consumo acelerava sua estrutura através da mídia.
\end{abstract}

Nessa época, o principal líder religioso da Igreja Universal do Reino de Deus, o Bispo Edir Macedo, era destaque na mídia porque um dos seus pastores, em um programa de TV da Rede Record de sua propriedade, chutara uma imagem de Nossa Senhora Aparecida, um dos maiores símbolos da Igreja Católica no Brasil. Este ato desencadeou uma campanha aberta na Rede Globo, líder de audiência, 
contra a Igreja Universal, que crescia assustadoramente no Brasil em número de adeptos. Enquanto isso, a violência começava a apresentar índices crescentes nos grandes centros urbanos do País.

Nas manchetes internacionais, o destaque era para o acordo de paz entre o primeiro ministro israelense Itzhak Rabin e o líder da Organização pela Libertação da Palestina (OLP), Yasser Arafat, para pôr fim a meio século de guerra. Na mesma época, destacava-se o assassinato do líder israelense, em pleno comício pela paz. A África do Sul ainda festejava a primeira eleição da história do país em que a maioria negra teve direito a voto, elegendo Nelson Mandela para presidente, em 1994. O presidente Carlos Menem, da Argentina, responsabilizava os muçulmanos pelo atentado à bomba que destruiu o prédio da Associação Mutual Israelita Argentina (AMIA), no centro de Buenos Aires, em 1994. Já os Estados Unidos passavam a orientar suas atividades contra as drogas, cujo consumo aumentara não só nesse país como no resto do mundo. Tentando chegar aos produtores da droga, o governo dos Estados Unidos fez ressurgir a soberania americana no Continente, ao operar abertamente em outros países com as chamadas tropas antidrogas. A França, por sua vez, apesar dos protestos internacionais de conservação do meio ambiente, havia retomado os testes nucleares no Atol de Mururoa.

No entanto, parece que esse contexto sócio-histórico não interferiu na escolha do invólucro do livro, repetindo-se mais um quadro de Di Cavalcanti.

A capa dessa edição traz a repetição da ilustração de Di Cavalcanti, usada na edição do ano de 1982.

Num retângulo, como se fosse uma janela, o diagramador da capa utiliza a ilustração de Di Cavalcanti como um intertexto. A repetição dessa ilustração deve ter sido mais uma estratégia da editora, utilizando-se desta repetição para uma atualização e coesão com a edição anterior. Essa retomada, provavelmente, não levaria ao mesmo sentido da formulação anterior com relação ao público, mas, com certeza, a novos sentidos, já que o contexto histórico desta capa é outro, pois as circunstâncias haviam-se modificado ${ }^{27}$.

Além disso, esse investimento na manutenção da mesma representação pela editora pode ter ocorrido diante da possibilidade de desdobramentos interpretativos da imagem em diferentes contextos, não submetidos às temporalidades, pela sua multiplicidade e riqueza de sentido. A circunstância dessa repetição não limitou a imagem a repetir o mesmo, pois, paradoxal e provavelmente, instaurou "o novo", ao ser reeditada numa outra conjunção histórica, inclusive pela assinatura do 
${ }^{28}$ Sendo assim, observaremos o que afirma Brandão (। 997, p.77): "[...] na medida em que retiramos de um discurso fragmentos que inserimos em outro discurso, fazemos com essa transposição mudar suas condições de produção. Mudadas as condições de produção, a significação desses fragmentos ganha nova configuração semântica". autor, que atestou o valor assertivo da imagem impressa. A autoria serviu de índice de verdade, de reconhecimento do sucesso da edição anterior, retomado para um redimensionamento, de acordo com a ideologia da instituição editorial no ano de 1995, ou pode ter sido repetida, também, devido ao nome legitimado e reconhecido desse artista plástico ${ }^{28}$.

A diagramação desta capa sugere ao observador que, depois de olhar a pintura de Di Cavalcanti, siga em ritmo ascendente na direção do título da obra, a seguir para o nome do escritor - Jorge, acima, e, a fim de complementar o sentido, volte para o nome Amado abaixo, observando, por último, o nome da editora que assina a edição. Esse ritmo de leitura sugerido passa, para o observador, a idéia de movimento, inquietação, altos e baixos, mudanças. Sugere um triângulo apontando para a direita, lembrando instabilidade pela posição de apoio no vértice, simbolizando ação e movimento A fonte usada para imprimir o nome Amado, como na maioria das capas, lembra estabilidade, e a que imprime o nome do romance sugere leveza.

título da obra está impresso em retângulo branco que, segundo Pedrosa (1982, p. I 18), "[...] é a cor das mutações, onde tudo pode ocorrer psicologicamente, significa ausência de cores e das especulações estéticas". A cor branca emoldurada pelo amarelo, cor que "[...] representa a energia, a luz" (PEDROSA, 1982, p. I I I), contribui para chamar a atenção das duas faixas em verde com o nome do autor em branco, ladeadas por ornamentos branco e vermelho entre as letras. A cor verde pode apontar para o "[...] equilíbrio resultante da união do azul com amarelo", como se provocasse o "[...] repouso das tensões pela sua relação com a natureza" (PEDROSA, 1982, p. III). Destacam-se os elementos em vermelho e a união das tipologias que registram o nome do autor. $\bigcirc$ nome da editora em preto é bastante visualizado na posição centralizada, como mais um elemento de reforço para a compra da obra, já que esta foi responsável pelo lançamento das obras de Jorge Amado por muito tempo.

Na quarta capa, a diagramação provoca um gráfico com ritmo semelhante, tendo como centro ótico a foto de Jorge Amado, autor da obra. A seguir, o olhar do observador sobe para as citações de Vinícius de Morais, depois a de Jean Paul Sartre e, acima, para a palavra Amado, descendo, posteriormente, para Jorge na parte baixa do formato retangular da capa. Esse discurso gráfico também é construído procurando dar efeito de movimento, de acordo com o clima do contexto da trama da obra literária. Ao elaborar essa diagramação, o publicitário, 
inconscientemente passa, por causa do movimento dos olhos do observador e pelo impacto, seqüência, ritmo e harmonia das informações expostas, a sensação de movimento para o público-alvo.

A imagem idealizada pelo publicitário é que vai garantir a inserção da produção artística no sistema de valores da publicidade, do consumo. $O$ conjunto dos elementos utilizados vai tornar a capa uma publicidade "enobrecida", por se tratar de cultura e arte como trabalho artístico, mesmo sendo reprodução. A sintonia do trabalho como rotulagem, que está dentro de um padrão estabelecido pelo uso na maioria das publicações produzidas naquele momento, vai dar personalização e qualidade ${ }^{29}$.

Dessa forma, a reprodução de obras de arte nas capas possibilita o acesso de trabalhos artísticos a uma classe social que não tem, muitas vezes, condições de adquiri-las. Amantes da arte chegam a considerar que, devido à quantidade de reproduções, diminuiu a carga "aurática" e a autoridade das artes plásticas, tornando-as efêmeras e insubstanciais, com valor "menor", principalmente por deixá-las ao alcance de qualquer pessoa. Mas não se pode deixar de observar que as massas tiveram a possibilidade de apreciar muito mais as artes, a partir não somente das capas, mas mediante os variados tipos de reproduções. A capa como publicidade insere uma linguagem de imagens que, além do valor artístico, adquire uma nova capacidade de impressionar o observador e destacar o valor de mercado.

A narrativa nesse trabalho do diagramador é composta de vários discursos e, devido a esse conjunto de forças de impacto, a capa despertará o interesse e poderá manipular livremente o observador-leitor. Nessa organização, o título sugere, a ilustração de Di Cavalcanti e a foto do autor demonstram e a diagramação, por meio de sua seleção e organização de dados, é reiterada pelo texto crítico, que os desenvolve, persuadindo e convencendo o observador leitor. O discurso publicitário é polifônico, pela composição de várias vozes: a voz do capista, a do autor da ilustração e as do escritor e locutores do texto verbal. Também é polissêmico, porque, com o uso de diversos códigos de diferentes significações, dá margem a várias interpretações. A partir do momento em que o discurso publicitário da capa é composto por diferentes discursos, a sua variedade e distribuição são recursos que enfatizam a seleção, dissimulando, muitas vezes, uma repetição.

As citações de trechos escritos por Vinícius de Morais e Jean Paul Sartre, por exemplo, vêm reforçar a tentativa de qualificação da obra pelo reconhecimento e legitimação desses profissionais no mundo literário e social, especialmente intelectualizado, informando quem são eles e de onde falaram e em que momento.
29 Para Berger ( 1972 , p.33): "[...] as reproduções são ainda usadas para reforçar a ilusão de que nada mudou, de a que arte com a sua autoridade sem par e sem confronto, justifica a maioria das outras formas de autoridade, de que a arte faz a desigualdade parecer nobre e as hierarquias excitantes". 
30 Marcus Vinícius de Melo Moraes, poeta, músico e cantor, nasceu em 1913, no Rio de Janeiro. Fez o curso de Direito no Rio de Janeiro e de Literatura Inglesa em Oxford. Ingressou na carreira diplomática em 1943, tendo servido em Los Angeles, Paris (duas vezes)e Montevidéu. Participou como jurado em muitos festivais de música, em diversos países. Destacou-se pelo lirismo dos seus poemas publicados em diversos livros, e pelas suas músicas que o levaram a ser conceituado como Papa da Bossa Nova. Foi amigo de Amado.

31 Jean Paul Sartre, filósofo francês, nasceu em Paris em 1905 , sendo o principal representante do existencialismo ateu. Foi um dos primeiros a utilizar na França a fenomenologia de Husserl e de Heidegger. Pensador contemporâneo, desenvolveu, além da sua obra de ensaísta, intensa atividade literária. Escreveu também várias peças de teatro. É considerado o filósofo da liberdade. Recusou, em 1965, o Prêmio Nobel de Literatura, para o qual fora então escolhido. Foi amigo deAmado.
Vinícius de Morais $^{30}$, poeta querido e reconhecido nacionalmente pelo público, ao dizer que Gabriela, Cravo e Canela "[...] é o melhor romance da literatura brasileira", introduz no texto um elemento de persuasão, diante da credibilidade de seu discurso para o leitor brasileiro.

Já a colocação de Jean Paul Sartre ${ }^{31}$, em uma conferência na Faculdade de Filosofia do Rio de Janeiro, dizendo que Gabriela, Cravo e Canela "[...] é um verdadeiro romance popular", faz com que a autoridade que the é dada e o espaço conquistado internacionalmente por esse autor ponham fim às dúvidas do consumidor.

É interessante observar a força desses dois discursos, nos quais os locutores narram como discursos pessoais. Convém salientar que, nesse momento, as marcas de primeira pessoa produzem sentido e funcionam como argumentos de convencimento. Portanto as expressões "para mim" e "posso" personalizam os locutores que se representam como indivíduos no mundo, responsabilizando-se pelas suas avaliações ou julgamentos. O mais importante é que os leitores, ao perceberem a posição privilegiada dos autores das citações, não observam que não são fatos, nem verdadeiros nem falsos, não designam relações de qualidade da obra, mas uma dimensão de apreciação dos seus autores. Foram inseridos na capa para convencer o leitor pela trama do intradiscurso e pelo suposto valor de verdade da proposição.

Já a foto do autor, em posição de relaxamento, escrevendo com o pássaro sobre a caneta, apresenta o artista como figura enigmática, diferente dos demais profissionais de outras áreas, produzindo a idéia de que trabalha divertindo-se, unindo natureza e cultura e demonstrando familiaridade com a pena (racional) e com o animal ( natureza), reiterando, inclusive, os motivos ou temas operados pelo autor. $\bigcirc$ observador, ao ver a foto, pode não perceber que houve uma intencionalidade no uso da fotografia na capa, e, mesmo que não tenha havido, a fotógrafa pode ter tido a intenção de registrar, provavelmente, isto. A foto pode ter sido escolhida, dentre várias outras, exatamente para construir a totalidade de sentido objetivado para a capa. O fato de a assinatura da foto ser de Zélia Gattai, esposa de Jorge Amado, que nesse período se individualizava como profissional elegendo como sobrenome Gattai e não Amado como anteriormente, é mais um dado para a intencionalidade de um registro único e especial, já que ela é cúmplice nos momentos da vida íntima do escritor.

Muitas vezes, quando se fala de um artista, ele é colocado como estereótipo de um ser "especial," "estranho" ao comportamento de um cidadão comum, inclusive com seu trabalho, sempre pleno de prazer, como se o próprio repouso 
fosse uma forma de trabalho e de criação, conforme comentado em capítulos anteriores. Por outro lado, reproduzem-se os parâmetros e as exigências do jogo mercadológico, que determinam os mecanismos de produção e consumo como prazer e até interferem na construção temática e formal da obra.

No final, a editora imprime a confirmação de Di Cavalcanti como ilustrador, fato que enobrece a obra literária, pelo respaldo da parceria com uma autoridade das artes plásticas no Brasil.

Da mesma forma, o diagramador, ao enumerar as várias obras de Jorge Amado, confirma que não se trata de um escritor novato e inexperiente. Nesse momento, a intensa produção literária do trabalho de Jorge Amado é confirmada pela retrospectiva dos seus trabalhos, o que também reforça o valor da obra no mercado como produto.

Nas orelhas, a editora repete o texto da edição do ano de 1982 e, logo abaixo, indica as obras de Amado. Como na maioria das edições, o capista utiliza sempre o mesmo critério, o discurso crítico e jornalístico ancorado nas imagens da capa para convencimento do observador da compra do livro.

Nessa representação, que traz a repetição de uma capa anterior em plano menor como uma janela, a editora destaca não só a importância do autor da ilustração, como também lembra ao consumidor a edição lançada anteriormente, em 1982. Essa edição havia obtido um grande sucesso de vendas, inclusive pela aplicação da sobrecapa alusiva ao filme homônimo. Como essa capa teve, na época, grande repercussão, possivelmente a editora procurou fazer a relação entre a capa anterior e a que deveria lançar naquele momento para dar notoriedade ao novo lançamento, já que a temática do texto literário ainda continuava plenamente contextualizada. Ou então, esta nova edição possibilitaria maior divulgação de uma imagem que fora coberta e, por isso, talvez pouco visualizada, devido ao uso da sobrecapa. Os preconceitos das práticas sociais, abordados por Amado nesse romance, assim como os valores que delimitavam o papel das mulheres na sociedade ainda continuavam semelhantes no contexto social brasileiro, mesmo depois de trinta e sete anos. Além disso, não podemos deixar de registrar que o Brasil voltava a ter um clima de expectativa, amadurecimento e esperanças políticas em um governo que continha a inflação, depois do impeachment. No cenário internacional, a África do Sul já começava a demonstrar o peso da sua maioria negra com a eleição de Nelson Mandela. $\mathrm{O}$ ambiente, portanto, favorecia essa nova edição. 



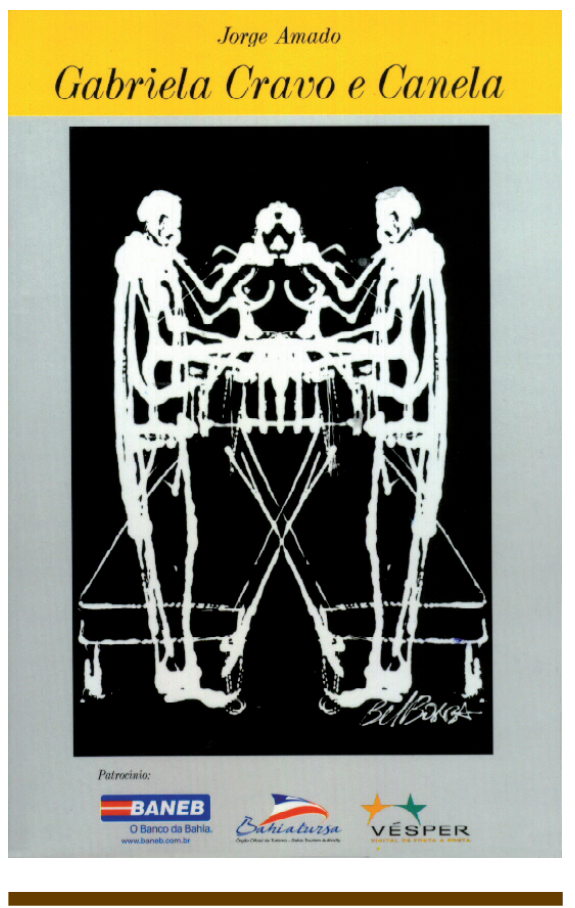

\section{Nona Capa}

Título Gabriela, Cravo e Canela

País BRASIL

Editora RECORD

Ano 2000

Autoria da capa Sem ReferêncIA

Autoria da llustração BeL BoRBA

Técnica a ilustração PINTURA SOBRE PAPEL 
bservando o lançamento dessa capa percebe-se a peculiaridade de uma edição de circulação popular porque foi distribuída junto com o jornal Correio da Bahia, inaugurando uma promoção na qual, a cada semana, o consumidor poderia adquirir um exemplar de um romance amadiano, junto com o periódico.

Brasil, nesse ano, ainda tinha como presidente, Fernando Henrique Cardoso, com a continuação da política de estabilização financeira, mas com taxas de juros altos. A política que vinha sendo desenvolvida, também incluía uma série de privatizações de empresas públicas, apesar dos protestos e ações judiciais movidas pelos partidos de esquerda, com a total liberdade de imprensa, mas com a concordância da maioria silenciosa da população brasileira. Uma série de escândalos de desvios de verba vinha acontecendo no ambiente político e o povo não demonstrava mais confiança nas decisões da Câmara e do Senado. As manobras da elite política em favor dos seus pares acabaram por cunhar um dito criado pelos jornalistas de que os resultados sempre acabavam em "pizza" (sem punição para os culpados). Por outro lado, desde alguns anos antes, vinha aumentando o número de protestos em prol do Movimento dos Sem-Terra, a partir do qual as pessoas tentavam, de toda maneira, conseguir área para plantar e viver. Esses protestos vinham provocando um dos maiores movimentos sociais do Brasil. No País, já estavam aparecendo as conseqüências da superpopulação nos centros urbanos, submetidos a todos os tipos de desigualdade, resultando numa violência cada vez maior, com assaltos à mão armada, seqüestros e ataques contra a pequena parcela mais favorecida da população, que passou a se enclausurar em suas moradias e condomínios e apelar para os serviços privados de segurança.

mundo se preparou para o réveillon da mudança do século com festas e fogos de artifício, apesar de grande parte das pessoas, com o incentivo da mídia, já ter considerado o réveillon do final de 1999 como marca do final do século $X X$. 
Existia otimismo na maioria dos países apesar dos conflitos, das guerras civis, da intolerância na proposta de integração econômica mundial e dos rumos da globalização.

Foi um momento de dúvida quanto à posição dos países que disputavam um espaço no tabuleiro geopolítico. Nesse panorama mundial, o Brasil ainda não sabia se encontraria um novo nicho na economia, já que vinha diminuindo o papel do seu setor industrial. A guerra no Oriente Médio continuava e, na África, a maioria da população continuava sendo dizimada pela fome, pela epidemia de Aids, outras doenças e guerras.

Os Estados Unidos pressionavam alguns países, principalmente os que tinham os seus produtos atrelados ao dólar, interessados sempre em recuperar seu caixa e aparecendo cada vez mais, no mercado, como os grandes beneficiários da crise econômica que se alastrava.

Na Bahia, havia a expectativa da instalação da fábrica automobilística da Ford, recriando uma atmosfera, aparente, de mudança e progresso local como solução para os problemas crônicos na área de educação, saúde e nos campos econômico e político.

A capa dessa publicação foi ilustrada por Alberto José Costa de Borba, artista plástico baiano, que assina Bel Borba. Nascido em Salvador em 1956, iniciou-se nas Artes, em 1973, na High School, Califórnia, EUA. Em 1976, ingressa na Escola de Belas Artes da Universidade Federal Bahia e passa a atuar no campo das artes com a pesquisa sobre a técnica de spray, em 1977. Durante a sua carreira, tem trabalhado com cenários, desenhos animados, espetáculos de teatro, painéis e pinturas, utilizando espaços alternativos (muros, fachadas, outdoors, escombros e outros como suportes) para suas manifestações artísticas. Essa artista participou de várias exposições em vários países, algumas com premiações de destaque. Uma das suas mais destacadas manifestações artísticas são "mosaicos", feitos em pedaços de ladrilhos brancos ou coloridos, com temas variados, aplicados em espaços públicos da Cidade do Salvador.

A capa mostra, em primeiro plano, uma cena em preto e branco, em técnica de xilogravura, na qual se percebe a representação de uma mulher com seios à mostra, de braços abertos, com a mão sobre os ombros de dois homens de perfil, aparentemente como se estivessem com o órgão sexual ereto. Os dois homens estão colocados em frente um do outro em simetria, como se fizessem parte de um todo dividido pela figura de mulher. Todos estão à frente de uma 
suposta mesa, da qual os pés da mesa (ou tabuleiro de iguarias) se confundem com os pés da mulher que estão por trás, ou talvez duas camas. A posição dessas pessoas, na prossêmica, indica, em nossa cultura, proximidade e intimidade. As duas representações masculinas, de perfil, podem lembrar dois homens ou duas formas de viver de um mesmo personagem, já que parecem figuras simetricamente iguais, apenas colocadas em posições contrárias, como se o observador estivesse visualizando as duas faces, direita e esquerda, de uma mesma pessoa. A figura de mulher de braços abertos, na cinésica, pode demonstrar honestidade e sinceridade, segundo Pease (1981, p.41-42), e os seios à mostra podem indicar que esta se expõe sem disfarce, revelando calor humano, provocando sexualmente o observador, ou apenas a forma de comportamento e vestuário das classes populares, embora sinalize para o erotismo.

$\bigcirc$ artista, ao imprimir uma mesa transparente em frente aos personagens, demonstra, de forma subliminar, uma representação que lembra o osso pubiano, a zona pélvica do corpo feminino, como se o observador pudesse sutilmente ver as formas do corpo da mulher que está por trás ou sobre a suposta mesa. Essa representação não somente reafirma a exposição explícita do corpo da personagem feminina, como também pode lembrar um tabuleiro, uma mesa ou uma bandeja com os pés que se cruzam no momento da sustentação, ao tempo em que pode significar as pernas cruzadas da mulher, o que, na cinésica, indica uma negação. Pease (1981, p.97-98) observa que a postura de cruzar as pernas pode indicar uma defesa, negação, ou, ainda, que a pessoa que cruza demonstra ser uma pessoa que não se conhece. Toda essa simbologia pode lembrar a representação de algumas mulheres, personagens amadianas, ou seja, a mulher que se expõe, expondo o corpo e o sexo à venda no tabuleiro ou se oferecendo para ser degustada. Lembraria o dito, dentro da cultura popular: a mulher que serve aos homens na cama e na mesa.

Nessa categoria de mulher, parece que Amado constrói alguns dos seus personagens, inclusive a Gabriela, que dava prazer sexual a Nacib e, ao mesmo tempo, cozinhava para ele e seus amigos. No romance, tal representação pode sugerir que esse tipo de mulher, para alguns personagens, é a mulher "ideal", a mulher que escraviza ou seduz os homens pela comida e pelo corpo. No entanto não se pode perder de vista que o ilustrador é sempre um homem e que ele pode estar representando a mulher do imaginário de sua cultura. Outra hipótese possível é que o ilustrador pode ter escolhido a representação dessa personagem entre dois tipos de 
homem ou a representação de um mesmo personagem em dupla personalidade para relacioná-la com os homens ilheenses na história do romance: de um lado, o homem que quer para companheira a mulher que se entrega aos prazeres sexuais e, do outro, o homem que quer a mulher recatada, que preserva a sua honra, conservando a identidade familiar, ao manter relações sexuais apenas com o marido, oficializado e aprovado pelo controle sócio-político-cultural dominante.

Nessa capa mais recente, o enfoque é a mulher, porém numa situação ambígua. Explicitamente nua, com as suas partes sexuais sobre a mesa, oferecendose como numa bandeja, tem, ao mesmo tempo, as pernas cruzadas em sinal de negação, de defesa, ou ainda numa atitude que, na cinésica, pode representar controle da fala ou nervosismo ou medo, controle do estado emocional e, ainda, falta de conhecimento de si própria. Pease (1981) afirma que essa atitude corporal de defesa (pernas cruzadas) deixa a pessoa que se posiciona mais confortável, diante da sua pretendida postura de reserva e controle. Por outro lado, Freyre ( 1962, p.63) em poesia de título "Bahia de Todos os Santos e de Quase Todos os Pecados", diz:

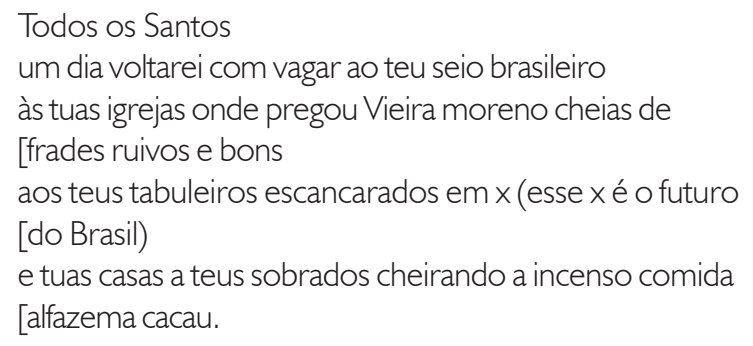

Sendo assim, parece que a posição das pernas cruzadas, isto é, o $X$ da questão pode ser fechamento, controle ou, também, abertura, escancaramento (tabuleiro aberto), o que condiz com as outras imagens que estão representadas nessa composição ilustrativa.

Tanto Amado como os ilustradores dessa sua obra literária são artistas do sexo masculino, então as representações da mulher correspondem a olhares do homem sobre a mulher, levando-nos a supor que esses homens podem ter idealizado a mulher representada, em cada capa, da forma ali reproduzida.

Nessa ilustração da capa ano 2000, a mulher tem as suas partes sexuais expostas em oferecimento e colocadas no centro óptico da composição como elemento de capital importância, o que pode estar demonstrando uma pessoa 
que se defende e se reprime, por opressão ou medo, mas pode ainda estar demonstrando disponibilidade sexual. Será que é assim que o observador do público-alvo atualmente vê a mulher e por isso foi representada dessa forma na capa? De acordo com Berger ( 1972, p.58):

Ser-se nu é ser-se visto nu pelos outros e, no entanto, não se ser reconhecido por aquilo que se é. O corpo nu, para se tornar um nu, tem que ser visto por alguém enquanto objeto. (A visão dele enquanto objeto estimula o seu uso como objeto). O nu está condenado a nunca estar nu. O nu é uma forma de vestuário.

A mulher nessa capa, assim como nas anteriores, tem relação com a sexualidade do homem, que a coloca nua para querer vê-la revelada, realizando o seu desejo e fazendo deste a fantasia de não ter nada impedindo o seu contato e os movimentos. Esta nudez talvez faça surgir a banalidade no momento em que a visão do espectador desvia o foco das expressões fisionômicas da modelo, que nessa ilustração não é demonstrada, e dirige o seu olhar para as partes sexuais, extremamente atraentes, mas que expressam pouco, reduzindo esta mulher a sua categoria sexual primária, tornando-a objeto de prazer do homem.

A cena, em preto e branco, demonstra o máximo de contraste graficamente, por isso a imagem lembra uma foto ampliada na técnica de alto contraste, ressaltando o claro e o escuro e promovendo a observação nítida e clara da ilustração.

Percebe-se, por conseguinte, que essa representação pode, não somente, retratar Gabriela, Cravo e Canela como também D. Flor e seus dois maridos e outros romances e personagens dos textos de Amado. Apesar da liberdade de expressão do artista e do olhar de cada um como pessoa, talvez não tenha havido uma preocupação em ilustrar, especificamente, a obra Gabriela, Cravo e Canela. Talvez tenha o artista generalizado a mulher das classes baixas ou tentado fazer ver características de outras obras amadianas, o que pode demonstrar uma nova forma de embalar, apenas fazendo ver as parcerias entre autor literário e artista plástico. Em outras palavras, pode-se colocar na capa uma ilustração, muitas vezes pouco conectada com a obra literária, apenas como adorno ou como espaço expositivo de um trabalho artístico inserido em homenagem a Amado. Não se pode esquecer que se trata de uma edição de tiragem popular, vendida anexa a um jornal diário, a preços populares. Esta parceria, provavelmente, atrairá o consumidor pela beleza do trabalho artístico, assim como pela representação do nome do artista plástico que assina a pintura da capa, no meio social em que o público- 
alvo vive. Ao mesmo tempo, poderá funcionar para o mercado editorial como elemento de notoriedade, projeção e atualização da obra no meio cultural.

A diagramação coloca a ilustração em preto e branco em fundo na cor cinza, uma cor neutra, que não interfere nas múltiplas informações sobrepostas, destacando em fundo amarelo ouro o nome do romance e, acima, o nome do autor em tipologia de tamanho menor. O gráfico provável de visualização levará o olhar do observador, depois de observar/ver a ilustração de Bel Borba, para os nomes do romance e do autor e, logo após, para os patrocinadores cujos nomes estão expostos na parte baixa da página. Este gráfico sugere, como na maioria das capas, um movimento consecutivo em ascensão, apontando para o nome da obra e do autor, e a fonte utilizada indica harmonia e suavidade, pela inclinação e sinuosidade da forma.

Na quarta página, impressa na cor amarela, em tonalidade mais clara de que a tonalidade da primeira capa, percebe-se apenas a marca da coleção Jorge Amado em vermelho, com grande destaque, dado o impacto causado por esta cor. Abaixo, no rodapé da página, a editora apenas cita as marcas das várias empresas que deram apoio ao projeto "Coleção Jorge Amado Correio da Bahia", da qual esse livro faz parte, e evidencia a realização do projeto com a colocação da marca das empresas realizadoras.

Não há discurso verbal na capa dessa edição, além do título da obra e do nome do autor.

A relação entre o lançamento dessa edição e a situação contextual no ano 2000 faz-se, mais uma vez, mediante o clima de mudança e esperado progresso conduzidos por grupos políticos na Bahia, e a necessidade de trabalho para o homem do campo, que já não aceitava o êxodo rural. A obra literária parece estar novamente contextualizada quanto a sua temática, e a ilustração escolhida pelo capista para a capa se encarrega de ajudar a atualizar, quando enfoca os modelos com características das mulheres daquele contexto social e da mídia naquele momento. Além do mais, a contemporaneidade do ilustrador ajuda a acentuar essa atualização.

Percebe-se que a capa dessa edição demonstra a especificidade da coleção que, para ser veiculada junto com um jornal diário nos mesmos pontos de venda do veículo e com preços acessíveis ao público de baixa renda, precisou de vários patrocínios. Esta forma de publicar confirma a tendência de uma popularização, cada vez maior, do livro no Brasil, proporcionando a aquisição e leitura de obras 
literárias pela população mais carente, o que outrora só era acessível às minorias cultas. Com esse tipo de publicação de custo mais barato, maior quantidade de leitores tem acesso a uma obra literária que, inicialmente, foi publicada, para outro tipo de público. Os consumidores dessa edição compraram o livro pelo valor de uma revista, o que é considerado um avanço da empresa editorial.

Em conclusão, durante quarenta e dois anos, as sete publicações brasileiras desse romance tiveram nove capas, que conservam as indicações de título, autoria e indicações bibliográficas de Amado. Registram o nome das editoras e dos ilustradores, mas não dão o crédito aos capistas, deixando dúvidas se o capista foi o próprio ilustrador ou qualquer funcionário da editora. Essas edições apresentam, nas orelhas e quartas capas, sempre uma mistura de texto crítico e jornalístico que aborda, sumariamente, a história do romance, provavelmente redigido por algum funcionário da editora (já que não vem explícito o nome do crítico literário), opiniões sobre a obra e a relação de romances escritos por Amado, evidenciando a sua intensa produção intelectual. Comparando esses textos, observa-se que são repetidos em várias edições brasileiras anteriores, apenas com algumas modificações para adaptação à nova edição. Fica bastante evidente que há, em todos esses discursos, uma forma de comunicar-se com o leitor, seduzindo para a compra, pois, ao relatar a trama desse romance, os editores imprimem as opiniões pessoais de alguns "críticos" ou de amigos de Amado.

Nota-se também que, na sua maioria, os ilustradores dessas edições brasileiras eram amigos de Amado, o que se pode considerar como uma contribuição para uma ilustração mais próxima do sentido almejado pelo escritor É possível que a intimidade entre escritor e ilustrador tenha possibilitado uma melhor adaptação na ancoragem da ilustração no texto literário.

Essas ilustrações impressas parecem ter sido escolhidas de acordo não apenas com os interesses da editora, mas também com o que acontecia, social e politicamente, naquele momento, no contexto do público-alvo, despertando a atenção dos consumidores, ao tempo em que também procuravam atualizar a obra literária no contexto brasileiro de cada época. Percebe-se, então, que isso possibilitou uma diferença nas formas de representação da mulher entre essas nove publicações. Na primeira e segunda capas, o enfoque foi nas mulheres na vida dos coronéis da sociedade conservadora de llhéus, ou seja, o poder político-social dominante naquele período e a situação dividida dos homens, que tinham uma companheira para ter os filhos e apresentá-la à sociedade, e outra para os prazeres do sexo. 
A mulher mestiça (pobre e empregada doméstica) somente mereceu destaque ilustrativo a partir de 1975, quando a obra literária amadiana passa a ser adaptada para a mídia eletrônica. O enfoque deslocou-se da família para a mulher mestiça, mas com muita influência do modelo apresentado pela adaptação eletrônica no Brasil (representado pela atriz Sônia Braga), que já demonstrava decotes acentuados e posições de cenas nas quais apareciam pernas e coxas com bastante ousadia. O grau de nudez das modelos impressas nessas nove capas acentuou-se, com o passar do tempo, causando a impressão de que, nos próximos lançamentos, a Gabriela poderá vir a ser ilustrada sempre nua. Observou-se, ainda, que os ilustradores escolhidos pelas editoras brasileiras foram do sexo masculino, o que deixou registrado apenas o olhar do homem sobre a mulher, o que consideramos um reforço para a visão masculina do autor literário.

Parece que toda vez que, no contexto, havia expectativas de mudanças progressistas, esse romance se encaixava, ou seja, é como se a obra literária se atualizasse e por isso poderia ser reeditada. Não se pode também deixar de registrar que, durante esses quarenta e dois anos, as ações de marketing executadas pelas editoras propiciaram uma maior facilidade de aquisição do produto livro pelo consumidor, contribuindo para a popularização desse romance.

Esses discursos dos capistas brasileiros serão comparados com discursos de algumas capas estrangeiras, no próximo capítulo, para observar e analisar as representações que imprimem "novas cores" ao romance Gabriela, Cravo e Canela. 


\title{
as Cores Terciárias \\ e as Capas Estrangeiras
}

\author{
"Quando se pode ler a tradução, \\ por melhor que seja o tradutor - tenho \\ tido excelentes, capazes, devotados - \\ existe sempre o detalhe, por vezes \\ mínimo, que choca, agride, dói: \\ onde foi parar a marca sutil do \\ personagem, o peso exato de uma \\ palavra? Imagina-se a dor no coração \\ ao ver xoxota ou xibiu, doces \\ designações da boca do mundo, \\ traduzidas por sexo de mulher, \\ vulva, bunda virando nalgas. \\ Nalgas, uma bunda de mulata \\ que se preza? Jamais!" \\ Jorge Amado
}




\begin{abstract}
A mistura de duas cores, uma secundária e a primária que lhe deu origem, pode gerar, também, uma terceira cor que os estudiosos chamam de terciária. Essas definições geradas por particularidades dos estímulos provocados pela cor dizem mais a respeito da sensação do que da percepção, classificando-se pelas formas de manifestação. Como se sabe e já foi referenciado, da percepção da cor fazem parte os fenômenos psicológicos que alteram substancialmente a qualidade do que é visto. Foram comparadas as capas estrangeiras, correspondentes ao olhar do capista que vive num contexto diferente de Amado, com a cor terciária, pois o resultado do discurso de cada capista estrangeiro é consequente e proveniente do discurso secundário (a capa brasileira) e da cor primária, a matéria-prima, o discurso de Amado. Assim, a união dessas duas cores, primária e secundária, ou seja, o texto de Amado lido pelo capista estrangeiro e a ilustração da capa da edição por ele observada, é que vai fazer surgir a cor terciária, a cor da nova capa estrangeira.

Foram observadas trinta e nove capas de edições estrangeiras, analisando-se inicialmente as coincidências nas escolhas das ilustrações, as repetições e a influência das capas brasileiras editadas anteriormente, para que fossem formuladas hipóteses sobre uma possível relação entre as ilustrações, o texto do romance e a imagem do Brasil (no imaginário estrangeiro) como país de origem dessa obra literária.

É necessário salientar que os comentários aqui registrados fazem parte do olhar de uma brasileira, nordestina e baiana, que conhece e identifica as características regionais descritas no texto do romance, e por isso ousa estabelecer essa possibilidade de relação.

Em trinta e uma edições, foram utilizadas, para ilustrar o invólucro do produto, representações que parecem ser da personagem Gabriela, além de outras que, possivelmente, são provenientes de um conhecimento anterior do capista ou do ilustrador sobre a cultura brasileira.
\end{abstract}

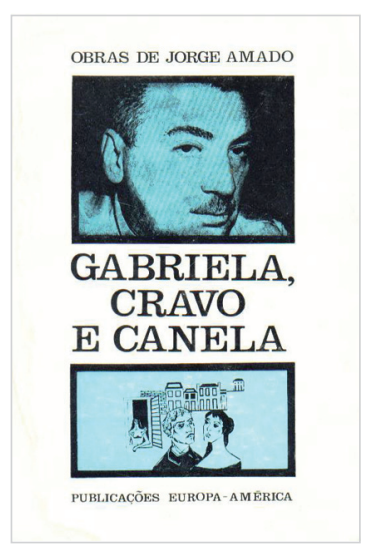

Portugal 1978 
Comparando-as com as capas brasileiras, percebe-se que apenas uma capa estrangeira enfoca o tema da família dos coronéis e a sua vida dupla, com a presença da esposa e da amante, como na primeira edição brasileira. É o caso da edição de Portugal 1978, na qual o ilustrador utiliza parte da ilustração de Clóvis Graciano, impressa na edição de lançamento no Brasil.

Em três capas especificamente, duas edições portuguesas, de 1978 e 1984 , e uma catalã, de 1997, o livro teve sua capa ilustrada com fotos da Gabriela, modelo criado pela atriz Sônia Braga e usado tanto pela novela da rede Globo como pelo filme, também baseado no romance, do qual são protagonistas esta atriz e o ator italiano Marcello Mastroianni.

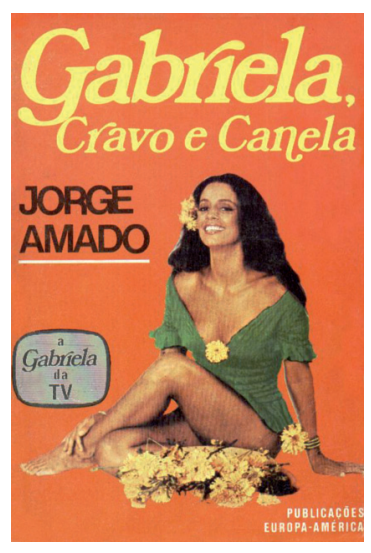

Portugal 1977

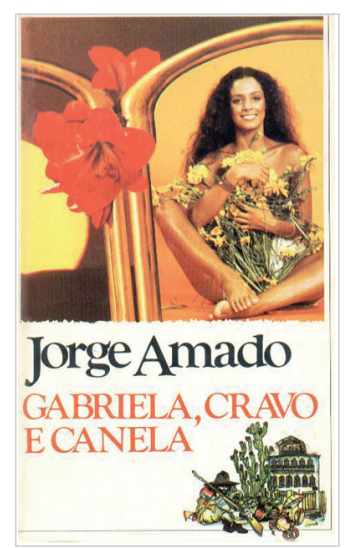

Portugal 1984

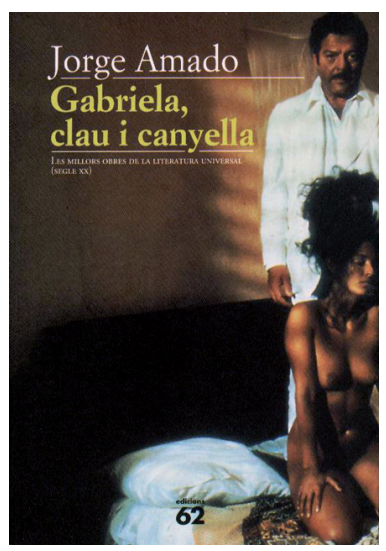

Portugal 1997

Em nove capas, a Gabriela foi representada com características de uma muIher aparentemente de etnia branca. Nessas ilustrações de alguns países onde a população é dominantemente branca, de olhos azuis e cabelos louros, as representações são de mulheres de cabelos negros, como se pode observar nas edições da Noruega [19--], Inglaterra (1984), Itália (1979), Tchecoslováquia (1974), Turquia (1973), Coréia (1976) e três da Alemanha (1962, 1964, 1968).

Supõe-se, então, que os capistas representaram-na dessa forma, buscando uma semelhança da mulher da ilustração com as mulheres do púbico-alvo, uma vez que, no romance, a cor da personagem está explícita. Amado (1966, p.216) define-a no seu texto dessa forma: 


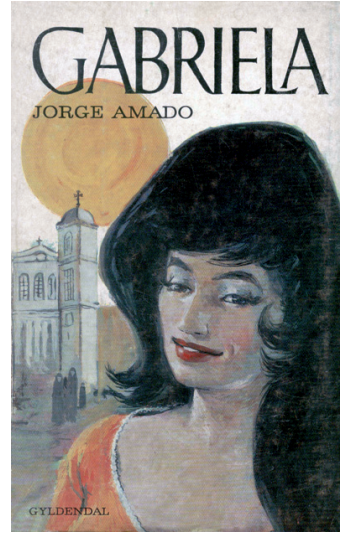

Noruega 19...
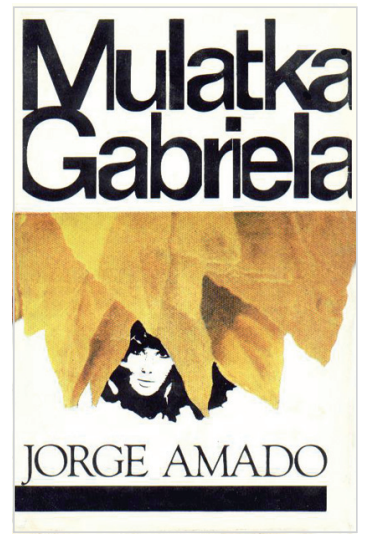

Tchecoslováquia 1974

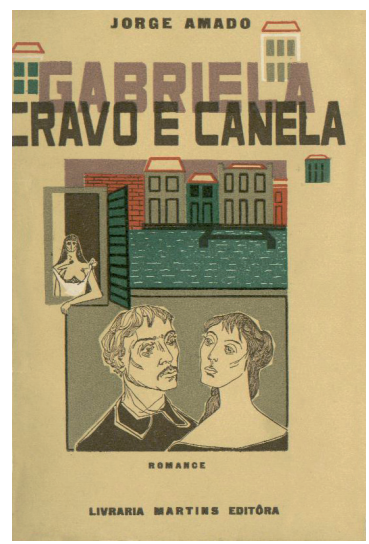

Alemanha 1962

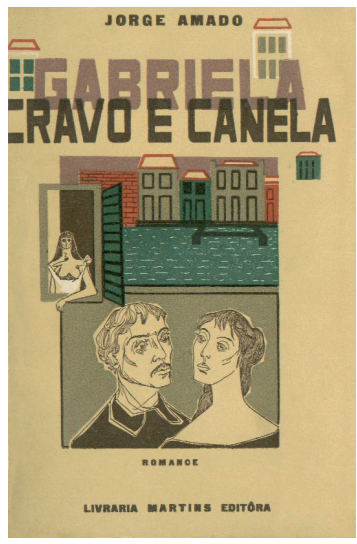

Inglaterra 1984

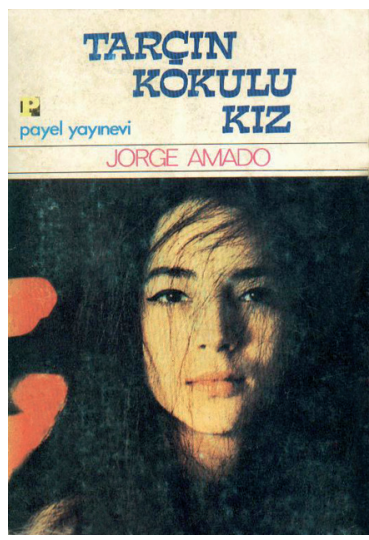

Turquia 1973

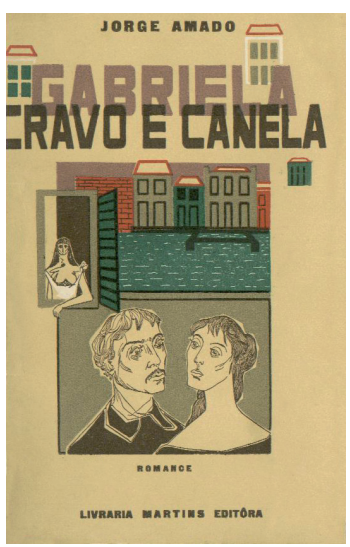

Alemanha 1964

\section{Jorge Amado}

Gabriella

garofano e cannella

Editori Riuniti I Romanzy

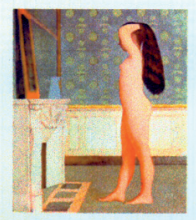

Itália 1879

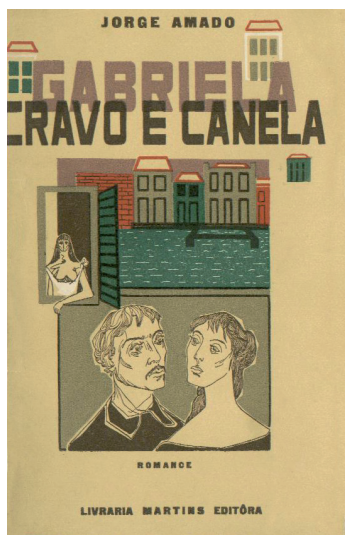

Coréia 1976

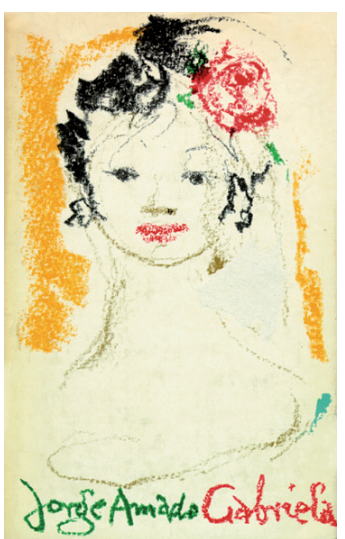

Alemanha 1968 
Nacib perguntava-se ansioso: afinal que sentia por Gabriela, não era uma simples cozinheira, mulata bonita, cor de canela, com quem deitava por desfastio?

Quinze edições estão mais aproximadas da descrição de Amado e possuem ilustrações da personagem Gabriela com traços assemelhados aos da mulher mestiça ou negra ou mulata, que foram as capas editadas nos Estados Unidos (1988), Lituânia (1994), Argentina (1972) e (1990), Rússia (1961), Suécia (1963), Alemanha (1966), Espanha (1998), Portugal (1960, 1965, 1974, 1978 e 1984), Dinamarca (1965) e Líbano (1990).

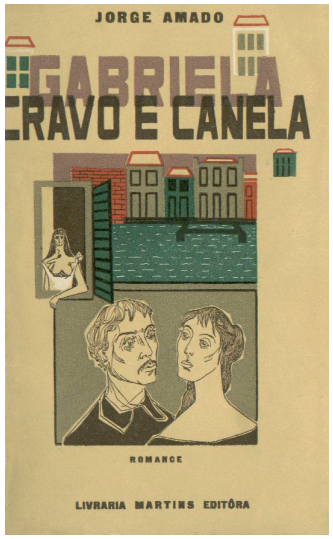

EUA 1988

OBRAS DE JORGE AMADO

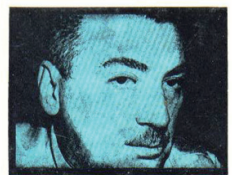

GABRIELA,

CRAVO

E CANELA

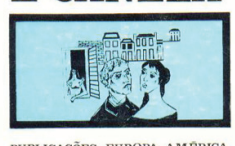

Rússia | 96 |

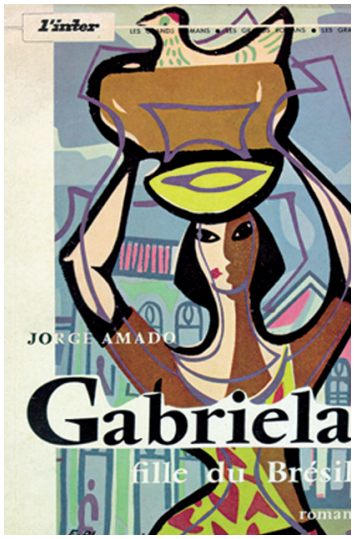

Lituânia 1994

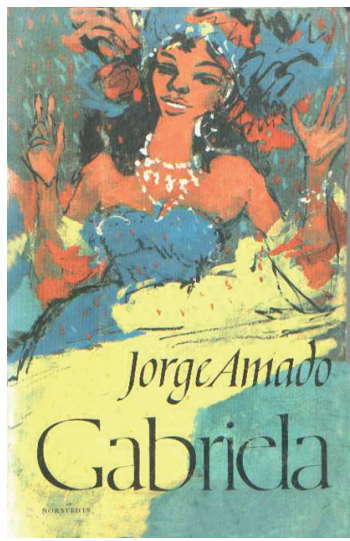

Suécia 1963

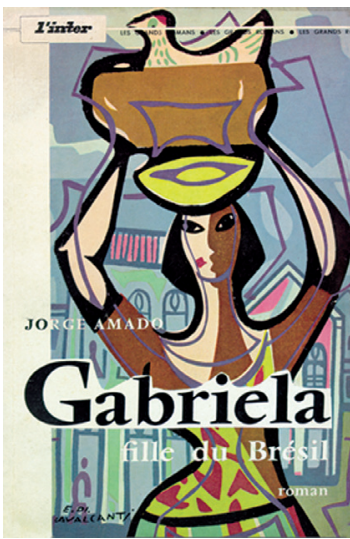

Argentina 1990

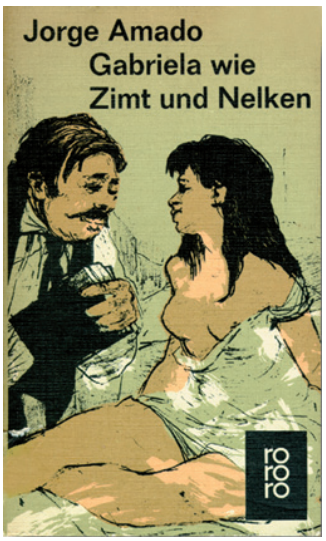

Alemanha 1966 


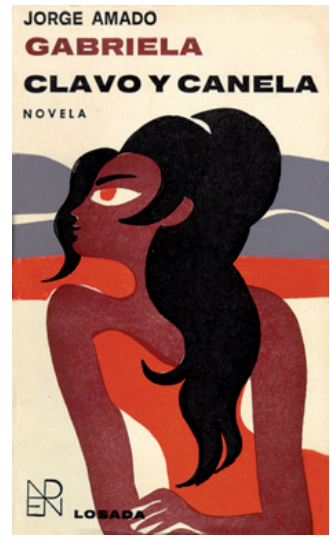

Argentina 1972

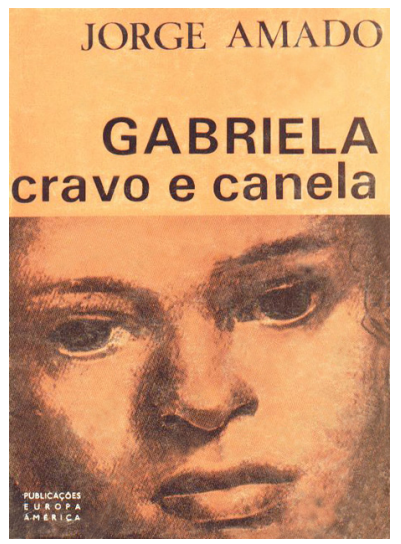

Portugal 1965

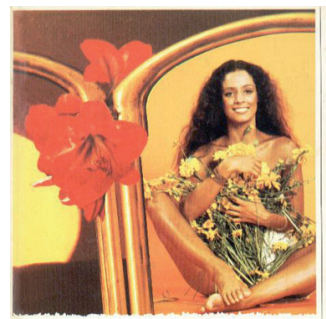

Jorge Amado

GABRIELA, CRAVO

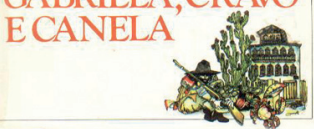

Portugal 1984

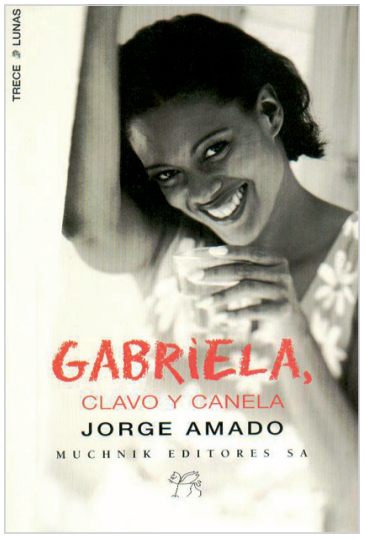

Espanha 1998

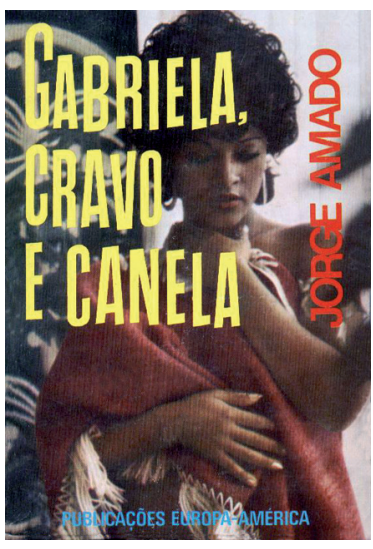

Portugal 1974

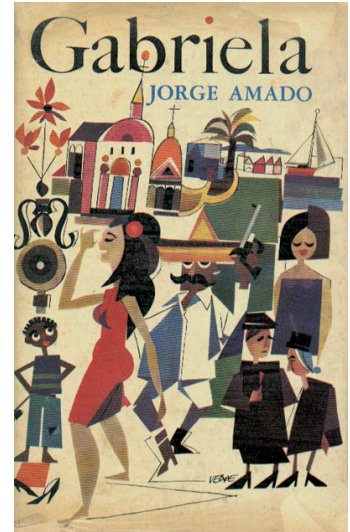

Dinamarca 1965

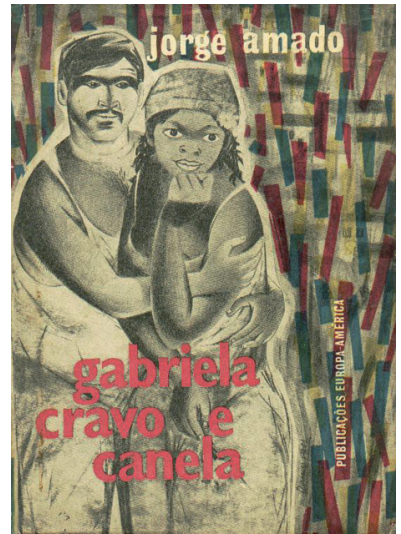

Portugal 1960

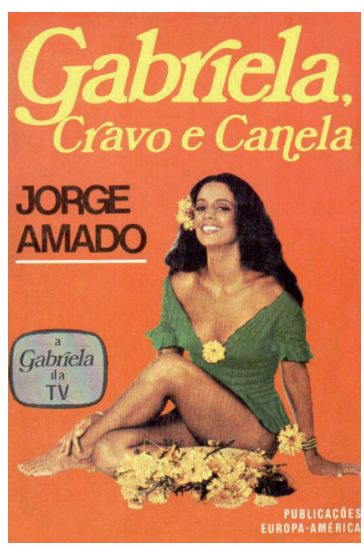

Portugal 1978

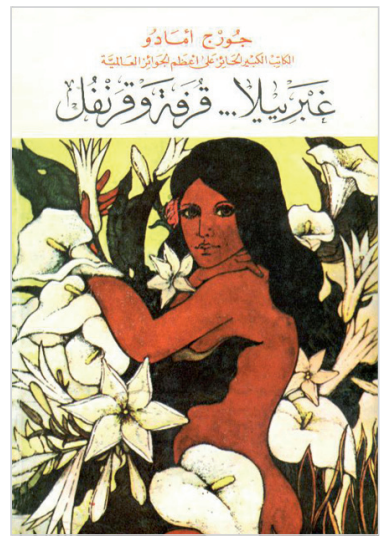

Líbano 1990 
Em nove países, os capistas também representam a Gabriela junto a elementos da natureza: Argentina (1990), Lituânia (1994), Estados Unidos (1988), Alemanha (1962), Inglaterra (1984), Líbano (1990), com ilustração igual à capa americana, Portugal (1978 e 1984) e Tchecoslováquia (1974). Podem estar representando a imagem que esses capistas têm do ambiente do país de origem da estória contada por Amado. O uso da natureza exuberante e paradiśaca também pode ilustrar, ideologicamente, países não industrializados ou representar o imaginário de países tropicais.

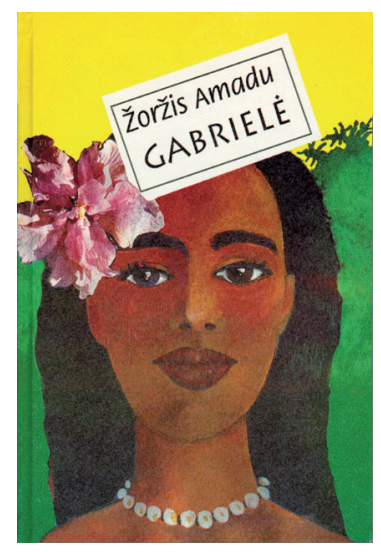

Lituânia 1994

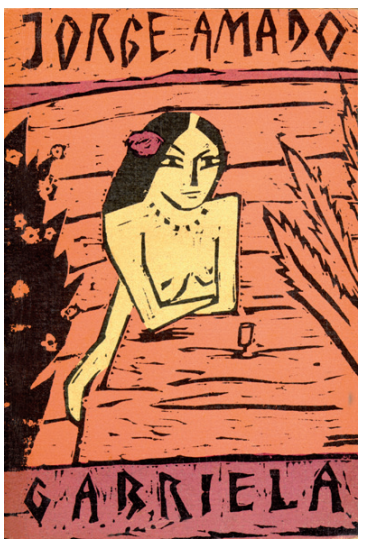

Alemanha 1962

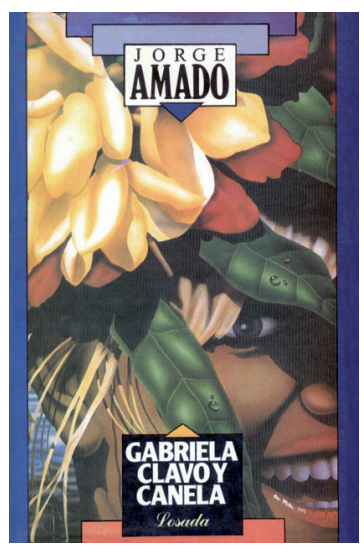

Argentina 1990

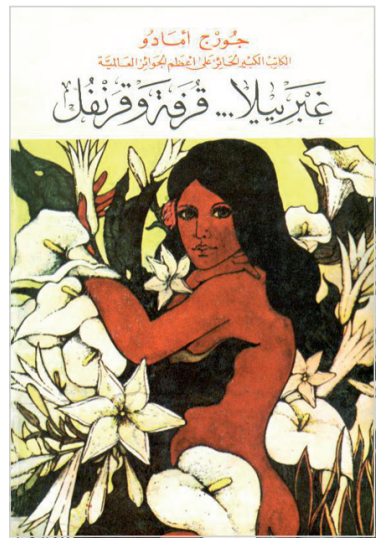

Líbano 1990

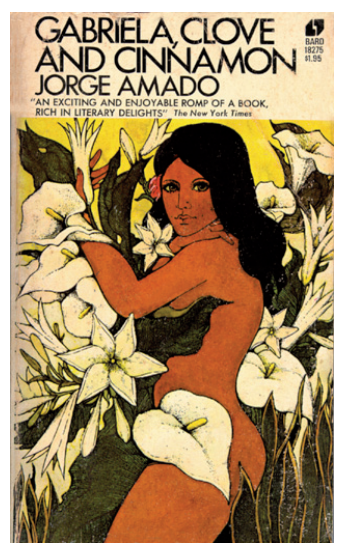

EUA 1988

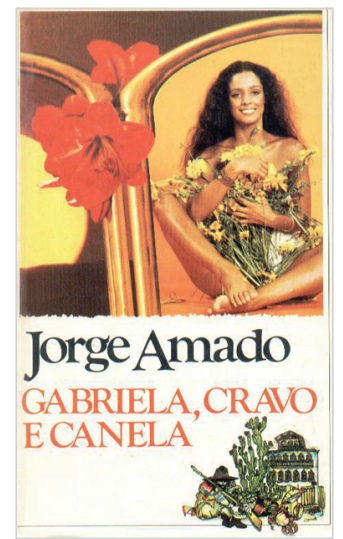

Portugal | 984 


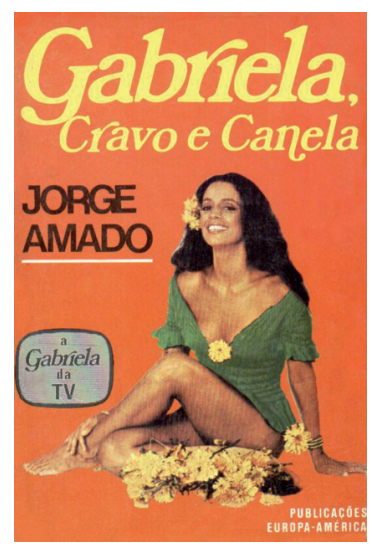

Portugal 1978

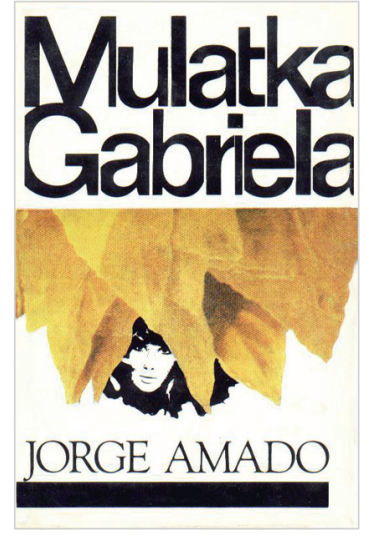

Tchecoslováquia 1974

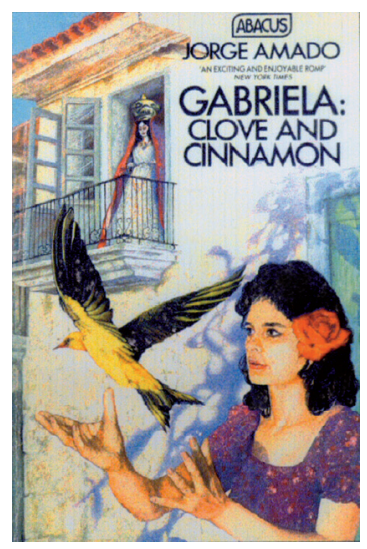

Inglaterra 1984

Uma capa apenas, a da edição de 1963 de Estocolmo, parece relacionar essa personagem amadiana com as baianas que desfilam nas Escolas de Samba do Rio de Janeiro ou, talvez, com as fantasias da cantora Carmem Miranda, pois ambas vestem trajes derivados da indumentária típica da baiana. As Escolas de Samba são muito conhecidas nos países estrangeiros por documentários e fotografias e por isso atraem muitos turistas para o Brasil no carnaval, quando se apresentam para o público. Numa das suas alas tradicionais algumas pessoas se vestem como típicas baianas, mas com muita sofisticação para desfilar. Já a cantora Carmem Miranda representava nos Estados Unidos, o país em que viveu, o Brasil, com a estilização de trajes semelhantes aos da típica baiana, como participante da Política da Boa Vizinhança entre estes países, na época da Segunda Guerra Mundial. Parece que apenas as edições da Argentina, de 1990, a dos EUA, de 1988, e a repetição da ilustração americana na edição para países de língua árabe, em 1990, fazem relação com a Gabriela descrita no texto, ou seja, demonstram claramente os traços da mulata de olhos verdes como cita Amado (1966, p.20 I):

Reclamava Josué, por que não fazia ele um soneto para aquela flor, aquela orelha, aqueles olhos verdes? Josué respondendo que um soneto era pouco, faria uma ode, uma balada.

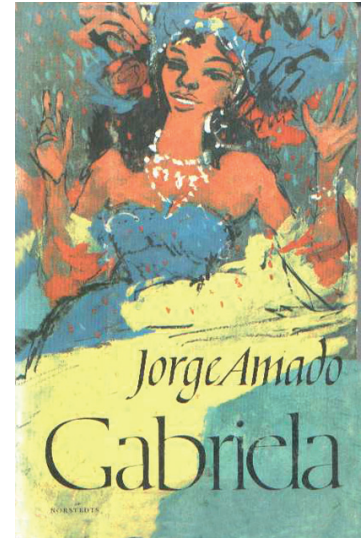

Suécia 1963 
Nessa ilustração da edição dos EUA, contudo, a modelo que representa a Gabriela vem acoplada ao imaginário de nativos com pouca vestimenta ou, possivelmente, da Eva na religião católica.

Somente a capa da Grécia (1983) representa a personagem aglutinada à esfinge grega.

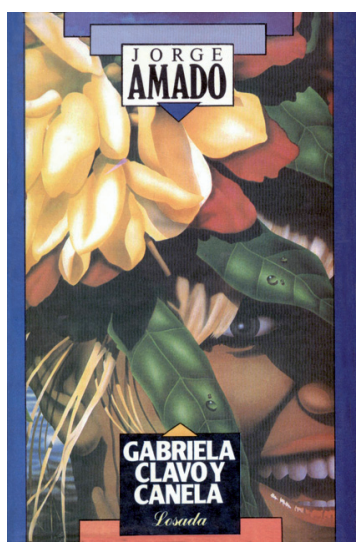

Argentina 1990

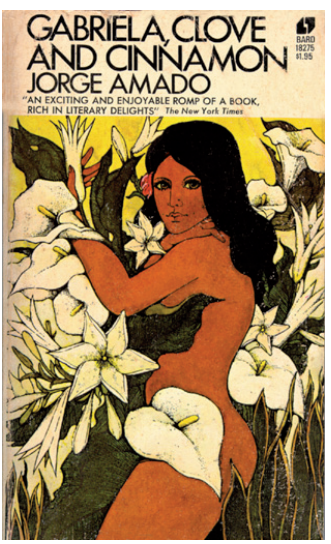

EUA 1988

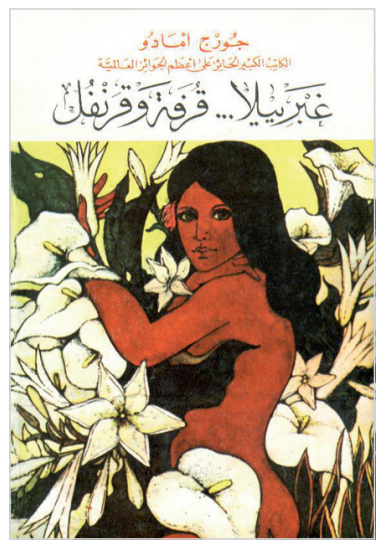

Líbano 1990

As esfinges da Grécia são prodigiosas construções de pedra em forma de leão deitado, com a cabeça humana e um olhar enigmático saindo da juba. Exis-

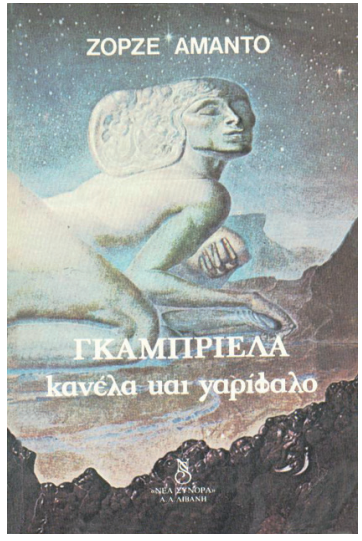

Grécia 1983 tem diferenças entre as esfinges egípcias e as gregas: as egípcias, normalmente, representam um faraó ou rei com corpo de leão para simbolizar a invencibilidade, a realeza animal, para que o soberano pudesse se distinguir dos outros homens. Segundo Biederman (1993, p.139-140):

Raramente também rainhas foram representadas dessa forma. A esfinge de semblante feminino da tradição grega tem suas raízes em um motivo lendário. Muitas vezes era munida de asas, e sempre representada como um demônio feminino mortal que se postava à beira dos caminhos, propunha enigmas aos viandantes e devorava aqueles que não conseguissem resolver suas questões. Isso ocorreu até que Édipo conseguiu superá-la com seu conhecimento, e a partir de então ela se tornou símbolo da eterna questão a respeito da natureza do 
homem, que deve ser respondida quando há necessidade de se descobrir o significado da própria existência. Foi esse o sentido que o barroco e o maneirismo atribuíram ao "enigma da esfinge", representada na maioria das vezes como um leão com cabeça feminina, o peito volumoso e o sorriso enigmático.

As esfinges da Grécia, com cabeças femininas, representam também a feminilidade pervertida, a devassidão, a vulgarização, e que somente poderia ser vencida pelo intelecto, pela sagacidade, ou seja, pelo oposto ao embrutecimento vulgar, de acordo com Chevalier e Gheerbrant (200I). A posição da esfinge como figura de mulher torna-a símbolo da terra, como se estivesse presa à natureza terrena, representando seres com ausência de elevação. Alguns autores também atribuem à esfinge grega a simbologia da vaidade tirânica e destrutiva do enigma e do mistério no início de algum destino: a mulher fatal. A relação proposta nessa ilustração parece ser da Gabriela como uma mulher devassa e pervertida, de natureza terrena, que não tem atributos intelectuais e, por isso, está presa às emoções e aos sentimentos da "terra".

Nove edições estrangeiras ilustram a personagem nua ou seminua. Basicamente, isto ocorre nas edições dos Estados Unidos ( 1988), da Alemanha (1962 e 1966), Itália (1979), Portugal (1978 e 1984), Grécia (1983), Líbano (1990) e Espanha catalã (1997).

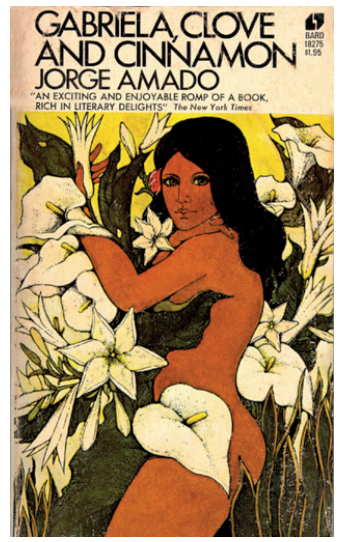

EUA 1988

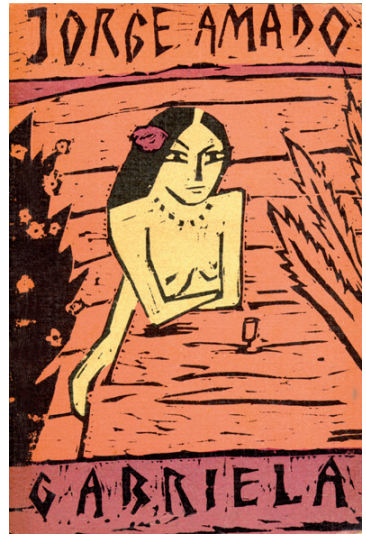

Alemanha 1962

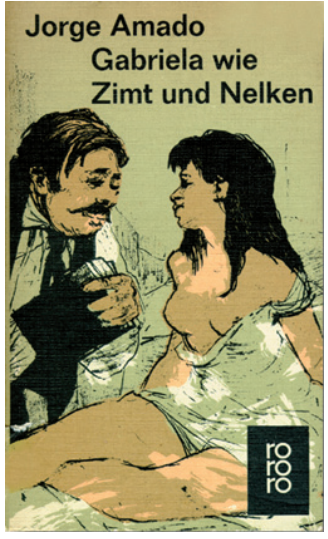

Alemanha 1966 


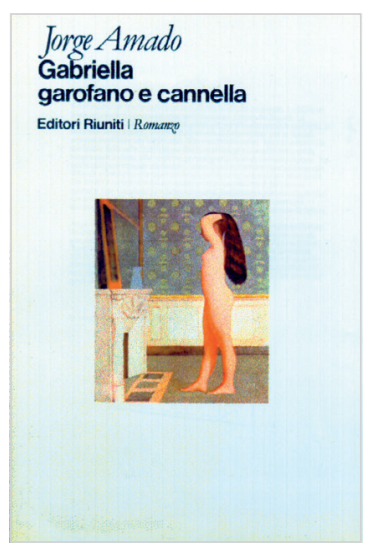

Itália 1979

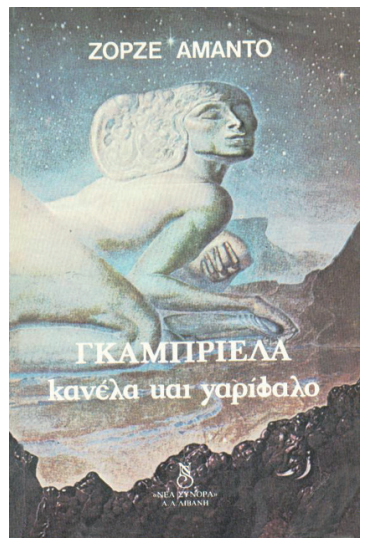

Grécia 1983

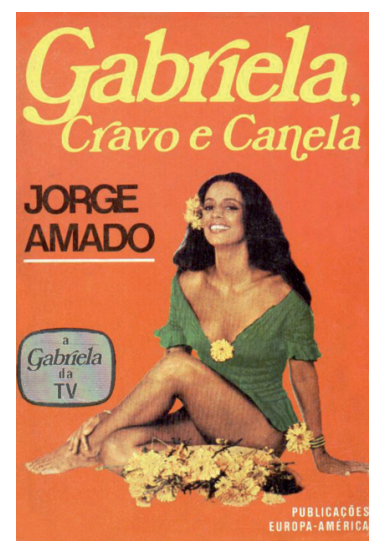

Portugal 1978

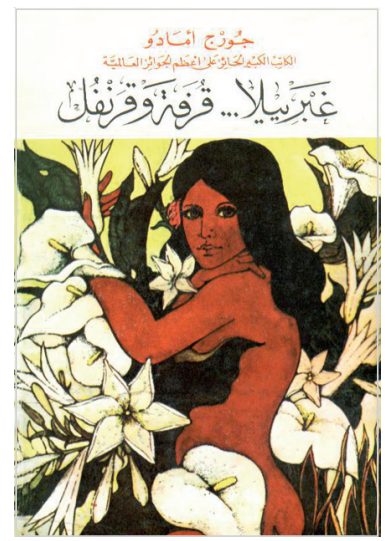

Líbano 1990
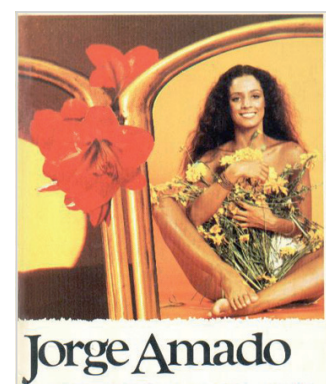

GABRIELA, CRAVO

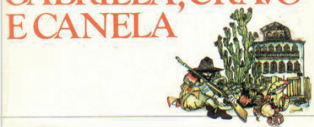

Portugal 1984

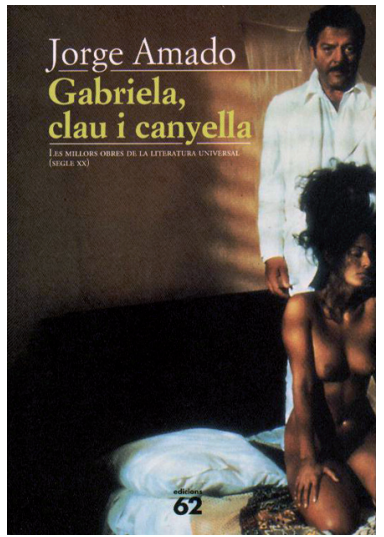

Espanha catalã 1997

Essa escolha pode estar reforçando a imagem de paraíso que diversos países estrangeiros têm do Brasil.

Por outro lado, algumas dessas edições iniciam a publicação de ilustrações da Gabriela nua ou seminua antes mesmo das representações dos capistas brasileiros, pois, nas edições brasileiras, a mulher nua só é inserida a partir do ano de 1973, com a ilustração de Carybé. 
Sete capas são ilustradas por modelos que divergem de algumas características descritas por Amado ou talvez se misturem com características do públicoalvo, que são as edições da Noruega [19--], Alemanha (1962, 1964 e 1968), Turquia (1973), Coréia (1976) e Itália (1979).

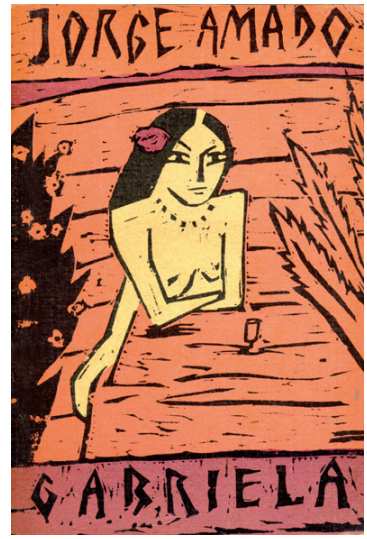

Alemanha 1962

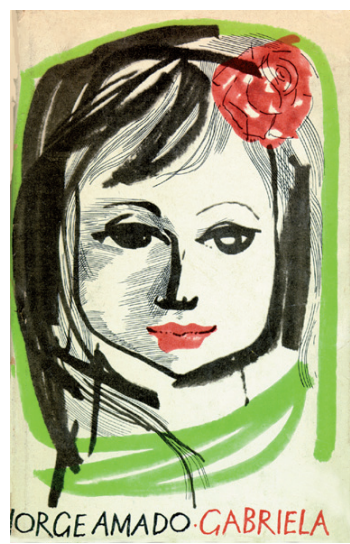

Alemanha 1964

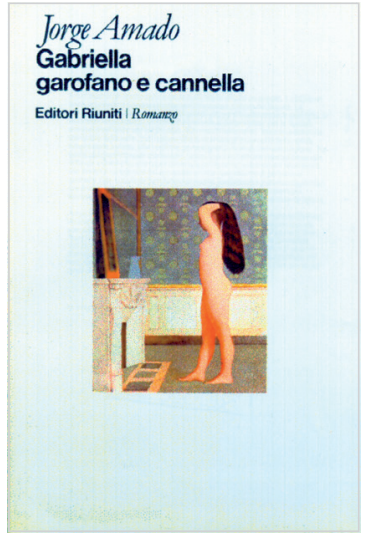

Itália 1979

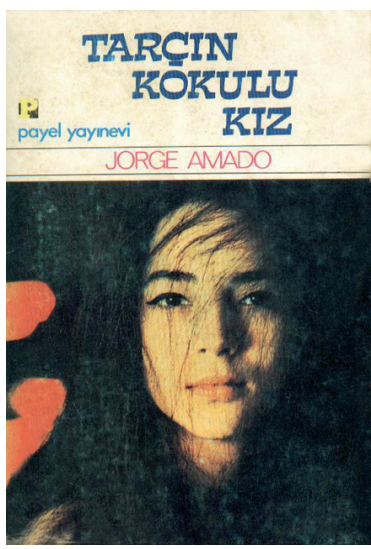

Turquia 1973

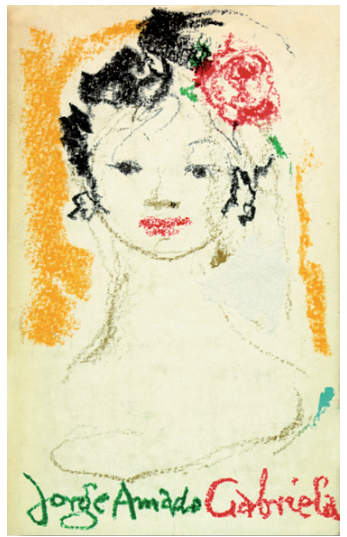

Alemanha 1968

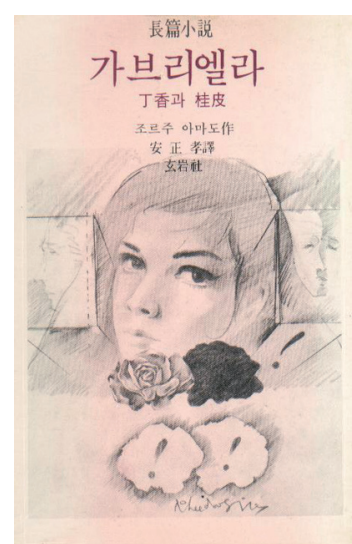

Coréia 1976 
Pode-se observar, ainda, que onze capas usam o título fracionado ou reduzido e o romance passa a ser intitulado apenas por Gabriela nas edições da Noruega [19--], Lituânia (1994), Rússia (1961), Suécia (1963), Alemanha (1962, 1964 e 1968), Hungria (1975), Dinamarca (1965), Polônia (1968) e Ucrânia (1970).

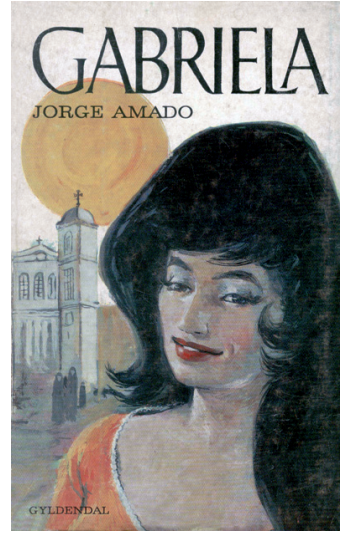

Noruega [19--]

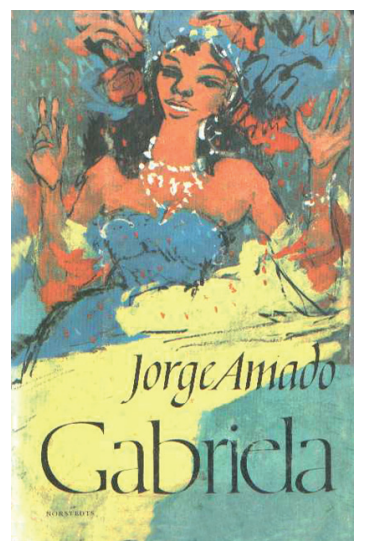

Suécia 1963

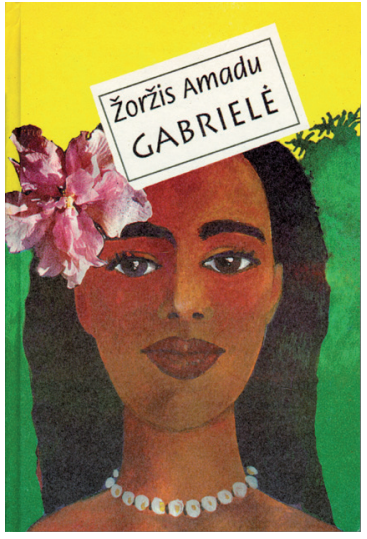

Lituânia 1994

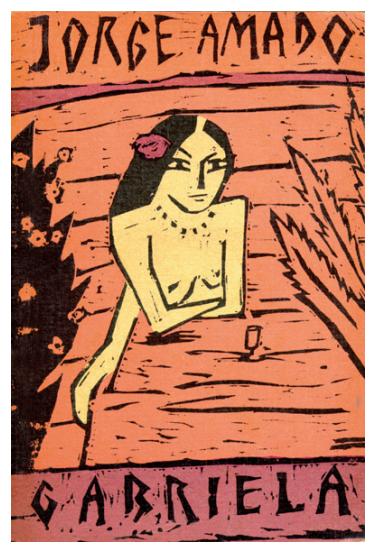

Alemanha 1962

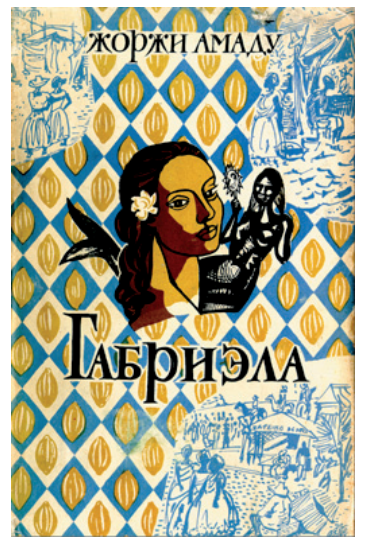

Rússia |96|

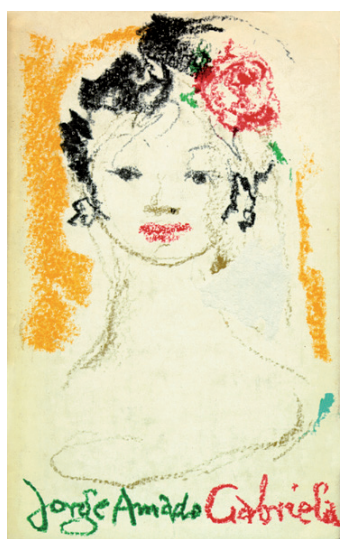

Alemanha 1968 


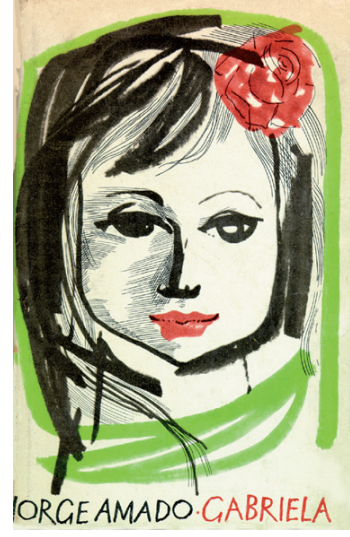

Alemanha 1964

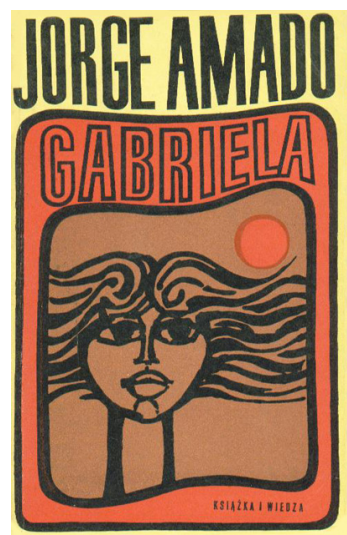

Polônia 1968

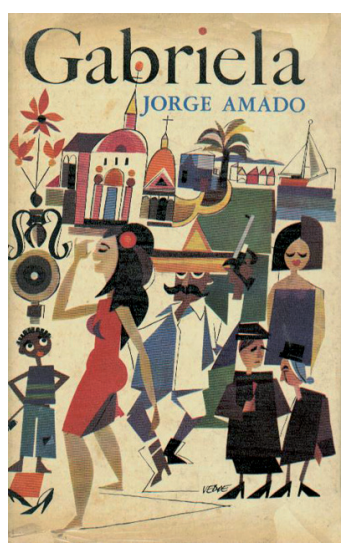

Dinamarca 1965

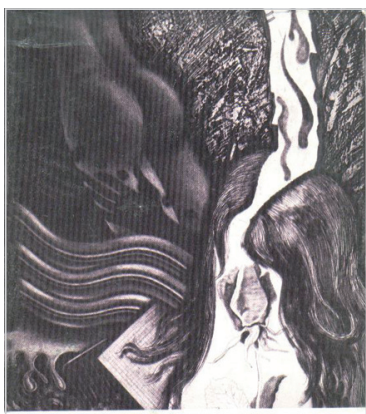
JORGE AMADO

\section{Gabriela}

Hungria 1975

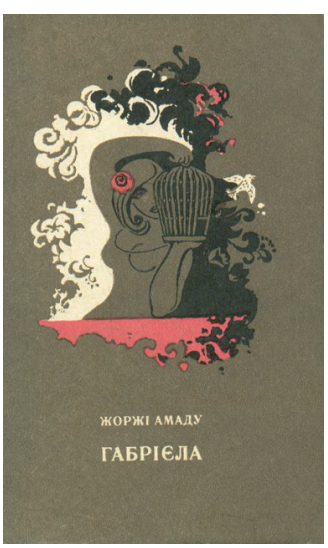

Ucrânia 1970

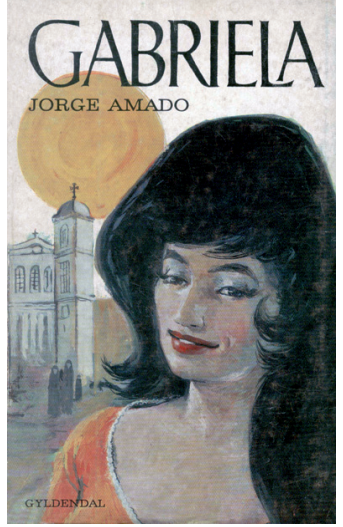

Noruega [19--]

Observa-se, ainda, que algumas edições modificaram o título. Na edição francesa, de 1959, o título passou a ser Gabriela, fille du Brésil, nas edições da Tchecoslováquia (1967, 1974 e 1977) o título adotado foi Mulatka Gabriela, acentuando os diferentes enfoques que o capista (ou a editora) gostaria de chamar a atenção do público-alvo. Na edição de 1977, está impressa a imagem de uma mulher de perfil, nas cores negra e branca, provavelmente, lembrando a origem racial da mulata brasileira. 


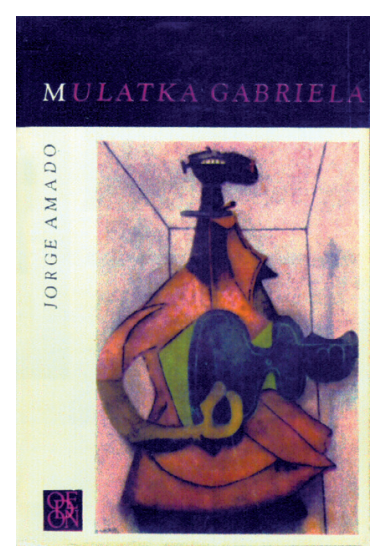

Tchecoslováquia 1967

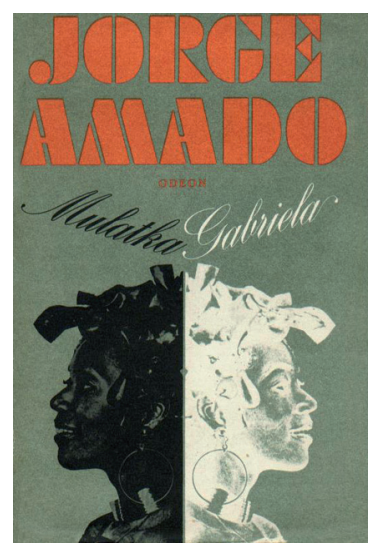

Tchecoslováquia 1977

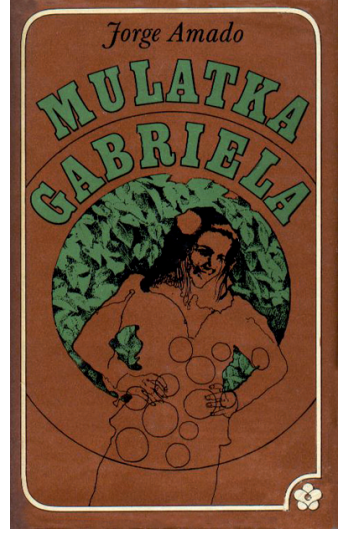

Tchecoslováquia 1974

Três capistas escolheram outros enfoques, bastante peculiares, para representar o romance. A capa da Espanha ( 1994) escolhe o sapato azul com que Nacib presenteia Gabriela para que ela freqüente os eventos sociais, depois de casada e em sua companhia. A capa da Hungria, de 1975, imprime uma pintura surrealista, tornando difícil estabelecer alguma relação com o texto de Amado ou com o Brasil, mas, por ser uma ilustração surrealista de pintor mexicano, pode dar margem a diversas interpretações do observador-leitor. A edição hebraica do ano de 1983 parece ter escolhido a imagem das palafitas, talvez por ser uma representação que lembra a Bahia-Brasil na visão de mundo do capista. As construções chamadas palafitas são habitações sustentadas por estacas sobre regiões lacustres ou alagadas, comuns em algumas regiões brasileiras onde residem pessoas de classe econômica baixa, embora este tipo de construção não faça parte dos cenários do romance de Amado.

Duas edições - a de língua árabe, (1984) e a persa (1988) - utilizam a flor cravo para ilustrar o romance. Provavelmente, os capistas tenham interpretado o título dessa obra literária como se a Gabriela cheirasse ao perfume do cravo (flor) e não ao condimento culinário. Outra hipótese (embora remota) seria uma relação com a Revolução dos Cravos que aconteceu em Portugal e que teve participação do Partido Comunista. Neste caso, o capista pode ter relacionado o seu trabalho à ideologia partidária do escritor Amado. 


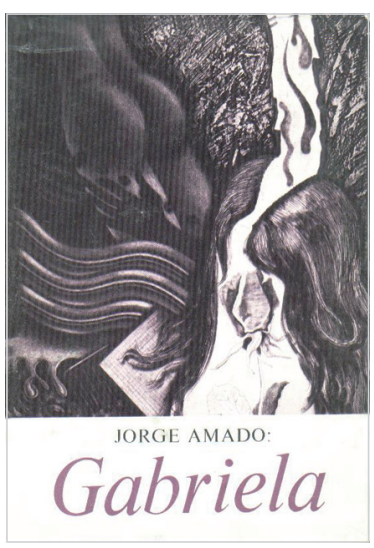

Hungria 1975

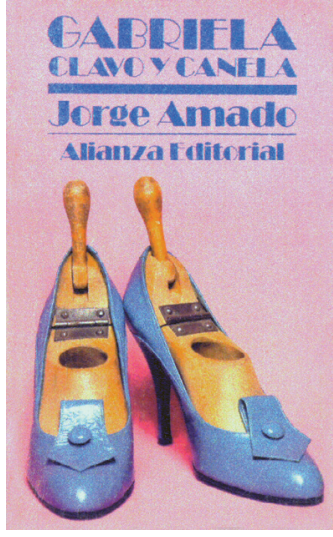

Espanha 1994

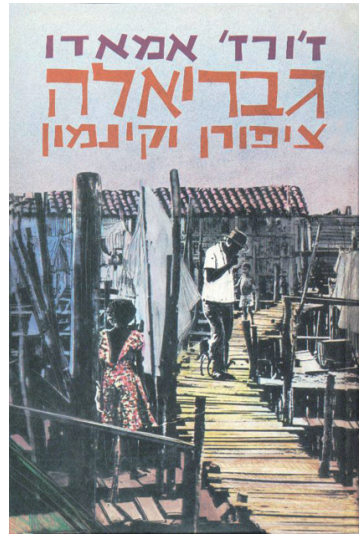

Israel 1983

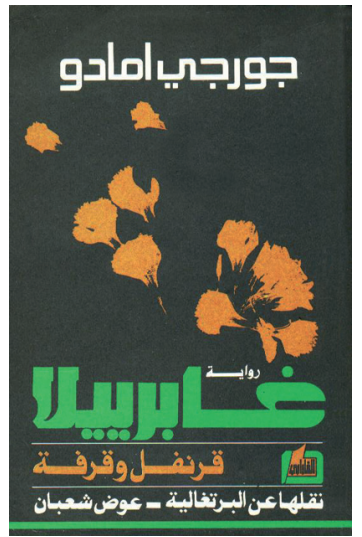

Líbano 1984

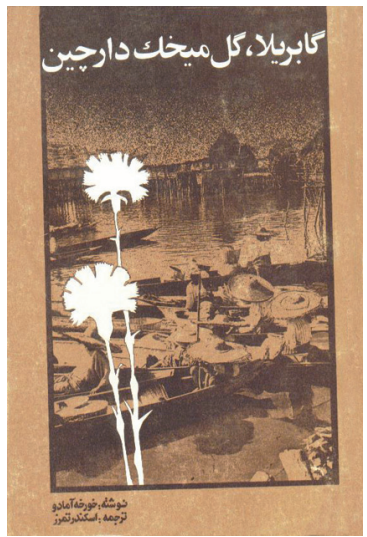

Irâ 1988

A edição da Dinamarca (1965) aparentemente relaciona um dos personagens com uma figura mexicana, como se o capista não soubesse a diferença entre os dois países, Brasil e México. A cena que ilustra parece que a personagem amadiana Gabriela está passando em frente a um coronel (ou um jagunço) parecido com um mexicano, pela presença dos grandes bigodes e pelo tipo do chapéu, assemelhado a um sombrero. 


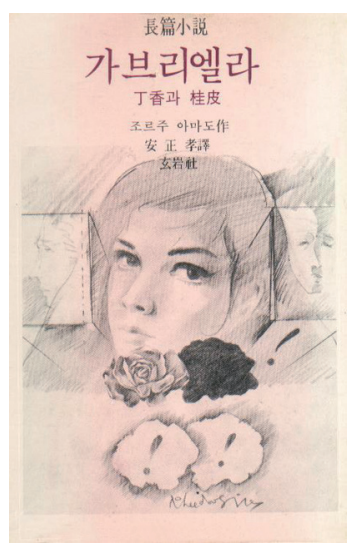

Coréia 1976

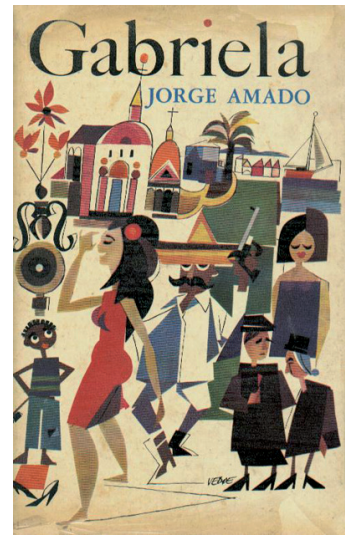

Dinamarca 1965

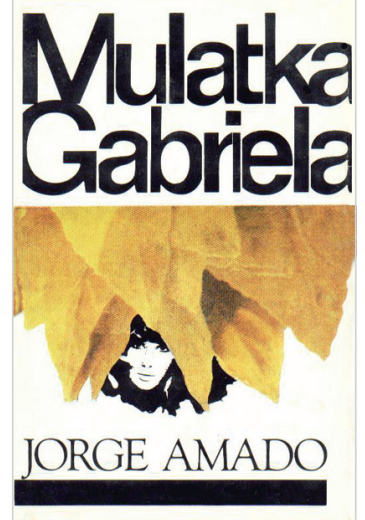

Tchecoslováquia | 974

A capa da edição da Tchecoslováquia 1974 mostra um rosto de mulher junto a algumas folhas que parecem de cacau ou de fumo, como se estivesse sob um pé de cacau ou, talvez, sob folhas secas que, pela sugestão do formato, isto é, folhas pontiagudas e num tom amarelado. Lembram também a forma como as folhas de fumo ficam secando nos galpões da indústria fumageira antes da fabricação dos charutos. Essa relação feita pelo capista pode ter ocorrido pelo seu conhecimento do Brasil como país grande exportador de fumo, além de que os charutos brasileiros são considerados de excelente qualidade e muito requisitados, (inclusive pelo mito de eles serem, ainda, enrolados, como no período da colonização, nas coxas das mulatas brasileiras). Mas, ao lado dessas folhas, a figura de mulher parece ter traços fisionômicos da mulher do público-alvo que a edição pretende atingir, o que nos faz pensar que essa ilustração pode, também, estar mostrando uma mulher do imaginário da Tchecoslováquia, sob uma árvore qualquer com folhas secas, sem nenhuma relação com o Brasil ou com o texto amadiano.

Diante de enfoques tão peculiares, serão analisadas algumas capas estrangeiras sem pretensão de uma análise aprofundada desses discursos, uma vez que seriam necessários não apenas maiores conhecimentos, como também uma vivência maior da cultura de cada país onde essas capas foram editadas. Então, foi feita uma seleção, a partir da identificação dos países onde foram publicadas, para tentar contextualizá-las. 
Entre os critérios de seleção, foram objeto de observação as capas editadas em países considerados do "primeiro mundo", para investigar os enfoques que alguns países ocidentais escolheram para representar essa obra literária que descreve a Bahia e, consequentemente, o Brasil. Foram escolhidas algumas capas, dando-se preferência às que eram mais ilustradas, com signos que eram de mais fácil reconhecimento e tinham maior relação com o objeto de estudo deste trabalho. Outro critério de seleção foi a facilidade de tradução dos textos inseridos, pois algumas edições estão impressas em idiomas em que houve dificuldade de encontrar tradutor. Contribuiu, também, para a escolha a facilidade de acesso e identificação dos aspectos culturais do país onde foi lançada a capa, pois existem capas que foram editadas em países cuja cultura é muito diferente da cultura brasileira, o que traria dificuldades para estabelecer uma relação entre o significante e o significado.

Feita a escolha, foram observados, em primeiro plano, o país onde foi editada, suas características principais, sua posição no mundo e participação no mercado internacional. Em seguida, identificou-se a autoria das capas, observando-se que a maioria não possui referência do autor, exatamente como nas capas brasileiras. Investigaram-se os registros da autoria das ilustrações, não só para tentar identificar as influências de quem elaborou o discurso escolhido pelo capista para iluminar a obra literária e demonstrar o título do romance, como também porque a ilustração é o grande foco deste trabalho. Observados esses dois itens essenciais para qualquer leitura e reconhecimento da utilização de algumas representações, foram selecionadas as convergências e divergências com relação ao discurso de Jorge Amado em Gabriela, Cravo e Canela, e àquele das capas brasileiras publicadas anteriormente, além de uma possível relação com a Bahia e o Brasil.

As edições estrangeiras com capas ilustradas são, em parte, edições de bolso, bastante populares, provavelmente comercializadas, em grande parte, em bancas de revistas. Muitas dessas edições possuem modificação do título da obra, e as informações sobre Amado, impressas nas orelhas dos livros, nem sempre correspondem à sua biografia. Além disso, as poucas informaç̧ões impressas correspondem às impressas nas edições brasileiras.

Na seqüência do trabalho, foram observadas nos discursos estrangeiros, as representações convergentes com o produto literário Gabriela, Cravo e Canela, e as relações necessárias para que o produto possa demonstrar e fazer conhecer outra cultura. Também foram observadas as representações divergentes como 
conseqüências das mudanças que sofrem as representações ao passar de uma cultura para outra. As convergências apontam para a preservação do sentido do conteúdo ou dos valores presentes no texto amadiano, apesar da mudança de contexto, de espaço e de tempo. Nas divergências, além das mudanças identificadas como consequentes da variação contextual, os capistas apresentam signos de sentido contraditório ao texto de Amado e à cultura baiana/brasileira, bem como alguns símbolos que produzem efeitos de sentidos muito distantes do enfoque dado no romance. Em alguns discursos divergentes, houve uma substituição de sentido (ou sentidos) que o capista não quis ou não pôde evidenciar no seu trabaIho. Essa suposição foi feita baseada no princípio, visto anteriormente, de que, para embalar produtos, é dever representá-los com o máximo de fidelidade, e a embalagem-capa deve iluminar e esclarecer o produto-romance através da nova representação.

Como critério de análise, partiu-se da concepção de que a ilustração como representação de uma obra literária, terá de incorporar o sentido "original", acrescentando, unindo, completando, ampliando, preenchendo e, principalmente, auxiliando a interpretação do leitor. Assim, a capa, como rótulo, deverá ter por objetivo falar do conteúdo que embala e fazer aparecer o texto literário que divulga, reproduzindo os valores e sentidos presentes.

A observação e a análise das capas estrangeiras obedecerão à ordem cronológica de lançamento das edições, relacionadas para este estudo. 

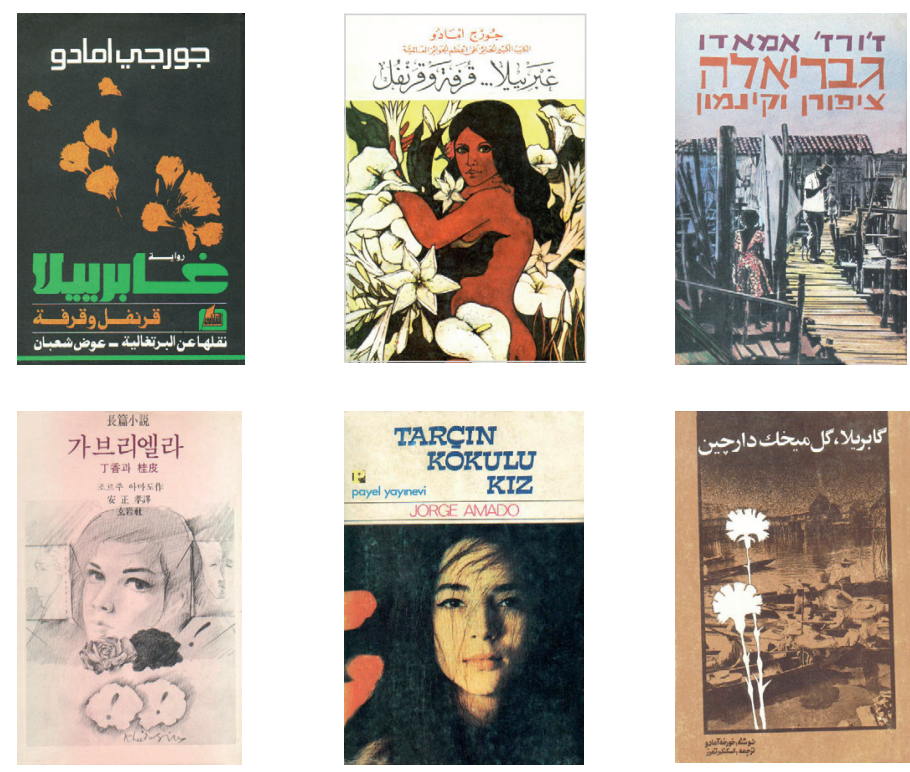



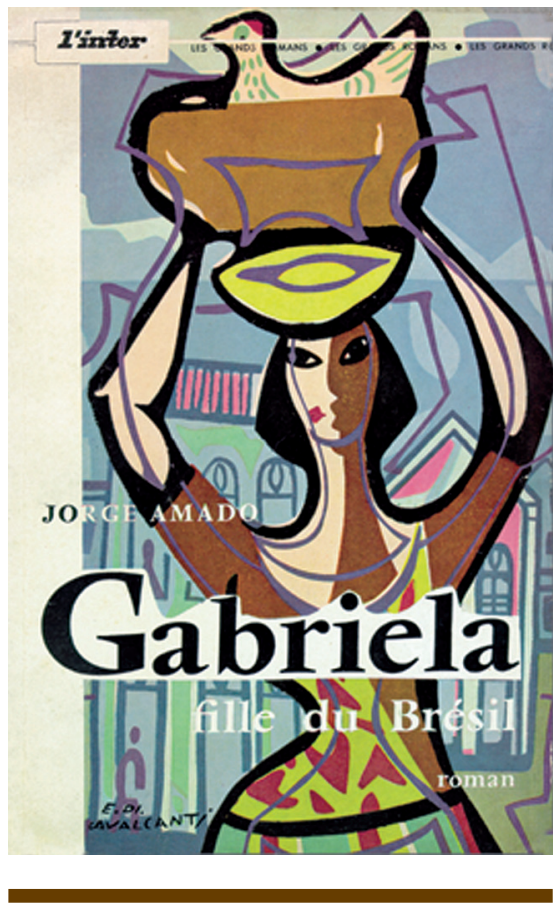

\section{Primeira Capa Estrangeira}

País França

Editora Éditions Seagers L'INTER

Ano 1959

Autoria da capa Sem Referência

Autoria da llustração Dı CAVALCANTI

Técnica a ilustração XILogravura

Tradução Maurice Roche e Violante do Castro

Versão do texto da capa Maria josé Passos ( para fins deste trabalho) 


\begin{abstract}
A
cor aparente ou acidental, segundo Pedrosa (1982, p.22), "[...] é a cor variável apresentada por um objeto segundo a propriedade da luz que envolve ou a influência de outras cores próximas". Compara-se esta cor, que aparenta ser uma outra devido aos reflexos de outras cores que estão junto a ela, com a situação do local onde o capista estrangeiro elaborou a sua capa, pois, devido à influência do novo local de publicação, da mudança geográfica ou mudança de tempo e cultura do público-alvo, a ilustração escolhida para a capa se modificará e torna-se-á variável e, consequentemente, bastante peculiar e específica.

Como os públicos-alvo, para os quais serão dirigidas as capas (estrangeiras), convivem com culturas bastante diferenciadas da cultura que Amado descreve em seu romance, a adaptação feita em cada capa (para a comunicação com o seu público) vai sofrer interferências, ou reflexos, que a deixarão, muitas vezes, completamente divergente do que é descrito no romance. Metaforicamente, o capista modifica o "tom" dado por Amado em seu texto, para aproximá-lo do "tom" que o públicoalvo reconhece: a cor local, a inserção ou aproximação na sua cultura. Esta "cor" já não é mais a de Amado e, sim, uma cor aparente que aconteceu por acidente, pela casualidade da publicação do romance naquele lugar. É a proximidade com a outra cultura que dará o reflexo de uma nova "cor", isto é, de um novo sentido.

Essa capa foi editada na França. No período de lançamento da edição, quem governava a França era o general Charles de Gaulle, líder do partido anticomunista União pela França, que tinha como um dos seus objetivos findar o levante dos pieds-noirs (pés-negros), colonos que lutavam contra a independência da Argélia.

A França, além de ter sido um império colonizador, tem como tradição um grande investimento em arte e cultura, possuindo em média, atualmente, mais de trezentas editoras que publicam, anualmente, milhares de títulos novos, perfazendo um volume de negócios editoriais de bilhões de euros a cada ano. A sua população costuma investir cerca de $30 \%$ das despesas familiares com cultura. Sua
\end{abstract}


tradição mostra que os franceses foram os primeiros leitores de revistas, por isso, os periódicos editados nesse país possuem grandes tiragens. A França se destaca na maioria das expressões artísticas como nas artes cênicas em que registra mais de mil companhias independentes de teatro, e no cinema, em que é o segundo líder mundial de investimentos cinematográficos, mesmo tendo a televisão como principal lazer da sua população.

O restaurador é o profissional encarregado de restaurar, recuperar ou consertar uma obra de arte. Com o tempo, as cores originais de uma determinada pintura frequentemente tornam-se obscurecidas, necessitando de um profissional que faça uma "repintura", ou seja, tente igualar as cores anteriormente presentes na pintura que será restaurada. Esse artista tenta recriar a aparência original da pintura, usando as mais novas tecnologias, mas não se pode deixar de considerar que a restauração é, também, uma coenunciação, pois, mesmo sendo seguida a indicação do original, não deixa de haver o olhar do restaurador. A técnica de restauração se baseia na possibilidade de deduzir, das partes observadas como existentes na obra que se está trabalhando, as que devem ser reconstruídas.

Metaforicamente, o ilustrador estrangeiro tem, com a obra literária, a mesma relação de um restaurador, pois, ao ilustrar uma nova capa para a edição estrangeira, faz funcionar o seu trabalho como uma repintura do texto, inclusive suplementado pela influência do coenunciador da tradução e do capista da edição que serviu de base para a tradução ou, ainda, das várias capas do país de origem. No trabalho do ilustrador, assim como no do restaurador, devem ser observadas as implicações estéticas e contextuais que podem vir a interferir no resultado final.

Quem primeiro ilustrou esse romance amadiano para um público estrangeiro foi Di Cavalcanti, e esta edição, feita no ano 1959, não somente é a primeira edição estrangeira, como também é a primeira que enfoca Gabriela na ilustração da capa do romance. Por isso, torna-se mais específica, constituindo uma situação mais complexa. Di Cavalcanti, pintor brasileiro que utilizou como tema, para muitas de suas telas, a mulher mestiça, a mulata, ao transpor um dos seus quadros para a ilustração da capa, não somente articulou sua obra com o texto, mas também elegeu um dos personagens da trama, fazendo deslizar o romance para a história da Gabriela. Daí surge um questionamento: o título francês - Gabriela, fille du Brésil - sugeriu a capa ou vice-versa?

O reflexo, segundo Ferreira (1975), pode ser o ato ou efeito de refletir-se, imitação, resposta ou reação, o que se produz por reflexão ou uma ação reflexa. 
Quando uma cor reflete os seus tons para outro lugar, demonstra no local onde está refletida a mesma tonalidade, as mesmas cores. O mesmo acontece nas capas estrangeiras que conservam as impressões da cultura de origem do autor literário, os reflexos conservam as tonalidades dadas por aquela cultura, por isso os reflexos são relacionados com as convergências entre as capas estrangeiras, as capas brasileiras e o discurso de Amado.

Já que convergir é dirigir-se para um ponto comum, afluir, tender para um mesmo fim, e uma lente de observação convergente aproxima os raios luminosos que a atravessam, procurou-se, também observar, com o olhar de baiana-brasileira, quais as representações usadas pelos capistas estrangeiros que se aproximam das representações de Amado e dos ilustradores brasileiros.

Na capa ilustrada por Di Cavalcanti, aparece o título Gabriela fille du Brésil, Gabriela, garota ou filha do Brasil, e uma ilustração que se supõe estar demonstrando este título, com a representação de uma mulher com traços bastante peculiares ao trabalho do artista ilustrador. É uma mulher com três tonalidades na cor da pele - marrom, preta e branca -, que pode estar refletindo as três raças da formação do povo brasileiro (índio, negro e branco) ou sintetizando o resultado mestiço - a mulata -, característica da personagem Gabriela, filha de pais de etnias diferentes (negra e branca), tão comum no Brasil, principalmente na formação étnica da Bahia, onde a população tem predominância da etnia negra ou de seus descendentes, do que em outras regiões do Brasil. Consideramos esta representação cuidadosa, uma vez que existe uma variação quanto à definição do que se considera mulata na Bahia, apesar de Amado graduá-la entre a cor do cravo e da canela, até insinuando uma variação para a cor marrom. Talvez Di Cavalcanti assim a tenha representado pelo conhecimento da cultura brasileira, por ter nascido e vivido no País.

A roupa da mulher representada na capa também converge para o texto de Amado, quando ele descreve a Gabriela vestida com vestidos de algodão estampado, presenteados por Nacib. As formas e cores lembram as estamparias tropicais, bem brasileiras. Sobre a cabeça da mulher, o artista colocou algo semelhante a uma rodilha e um vaso de barro ou uma cesta com uma galinha, representação de um antigo costume popular de transportar objetos. A rodilha é um rolo de tecido, usado pelo povo do Recôncavo baiano, para amortecer o peso e, ao mesmo tempo, equilibrar o que se carrega sobre a cabeça. Talvez que a escolha da representação, uma galinha no cesto, tenha sido feita pelo costume brasileiro de carregar 
as coisas na cabeça, ou para relacionar com os acontecimentos do momento. Quem sabe até para ridicularizar ou chamar atenção para um animal que aparecia na mídia européia no período de lançamento da edição estrangeira, época da guerra fria. Segundo Brener (1998, p.218), Nikita Kruschev, líder soviético, havia prometido que, nos anos 70, a prosperidade do mundo socialista ultrapassaria a do Ocidente, e pretendia dinamizar a economia sugerindo reformas, e por isso aparecia para as câmeras beijando criancinhas e examinando as galinhas em cooperativas, como acompanhamento do progresso econômico prometido.

Também poderia estar sugerindo uma representação dos cultos africanos nas cerimônias iniciáticas, especialmente no candomblé, citado várias vezes por Amado na trama, em que uma galinha é posta numa bacia sobre a cabeça da pessoa que deverá ser iniciada, significando sua entronização definitiva no culto e no mundo dos mortos.

Como fundo dessa representação, Di Cavalcanti pintou um casario que lembra as casas do povo de llhéus, cenário do romance. Os tons usados no casario também convergem para a sobriedade.

Muitas vezes, um observador, ao olhar para uma determinada cor, não observa que houve uma mudança de coloração e continua a considerá-la igual à cor anteriormente vista, por uma codificação já preestabelecida por convenções contextuais, dando a essas nuances um mesmo valor subjetivo. É comum olhar para uma superfície originalmente branca que, com o passar do tempo, o enveIhecimento tornou-a amarelecida, mas continuarmos conceituando esta superfície como branca, dado nosso conhecimento anterior. Essa coloração vista como branca, por um saber antecipado e previamente codificado, chama-se de cor velada, escondida e dissimulada, pois a cor refletida é outra, embora, pelo conhecimento anterior, o observador continue percebendo-a da mesma forma.

Comparou-se esse efeito de valor subjetivo, das divergências encontradas nas capas estrangeiras em relação ao discurso amadiano, às capas feitas para as edições brasileiras e à cultura baiana. Divergir quer dizer afastar-se do ponto de origem, separar, discordar, estar em desacordo, não combinar. Uma lente de observação considerada divergente afasta os raios luminosos que a atravessam. As representações do capista estrangeiro, afastadas do sentido dado por Amado em seu texto, podem ter sido resultado de seu olhar imbuído de outra cultura. Podem ter sido baseadas em alguma percepção anterior, presente na cultura ou no imaginário do seu país. Assim, sem perceber as novas nuances, o capista, com 
base no seu saber anterior, atribui um novo sentido ao texto amadiano, conceitua e escolhe a ilustração para representar o título ou o romance, de acordo com o já estabelecido por sua cultura ou pelo imaginário sobre o Brasil.

Na capa francesa de 1959, percebe-se, como divergência, que o título do romance não foi mantido, e o novo título "Gabriela filha ou garota do Brasil" indica a personagem como o tipo da mulher brasileira. $O$ modelo criado para a personagem Gabriela pode contribuir para a construção de um estereótipo da mulher baiana e brasileira. Leitores que não conhecem o Brasil podem passar a identificar a mulher brasileira pelo modelo da ilustração aliada ao título e à descrição de Amado.

Essa mudança no título tende a uma descaracterização da obra amadiana, já que é pelo título que, na maioria das vezes, o leitor identifica uma obra literária, além de ser um desrespeito à integridade da obra.

No caso de Di Cavalcanti como ilustrador, ele pode ter operado aproveitando e identificando seus quadros com a produção de Amado ou se utilizado da estereotipia ou imagem que talvez $\circ$ francês médio tivesse engendrado sobre $\circ$ Brasil. 

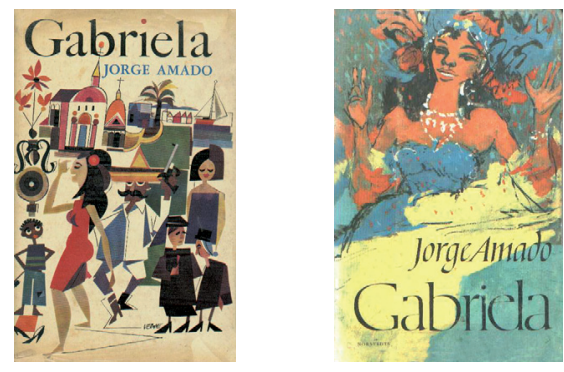

GABRIEIA

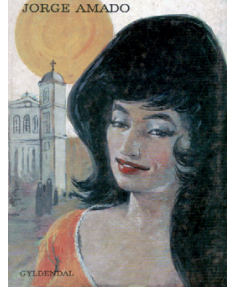





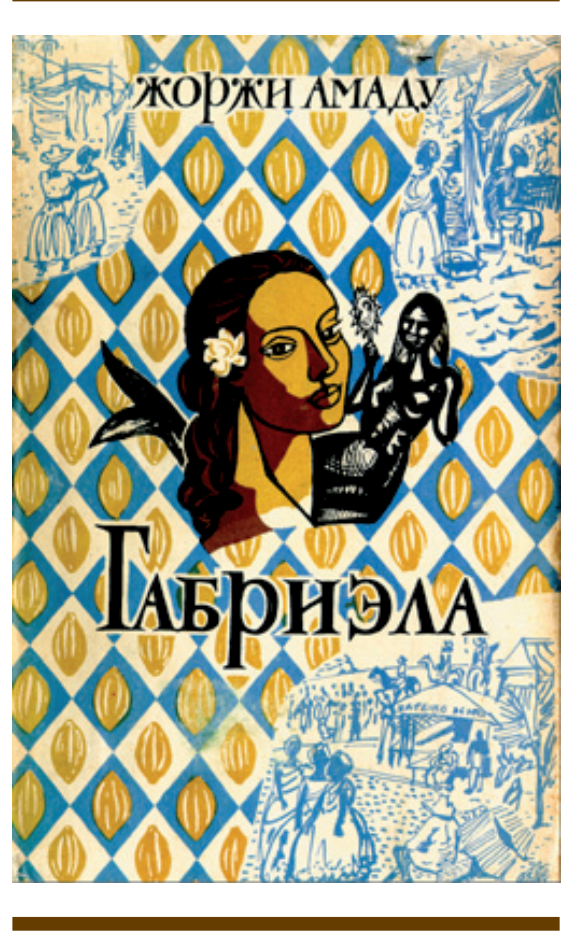

\section{Segunda Capa Estrangeira}

Título Gabriela

País RússIA

Editora Sem ReferênCIA

Ano 1961

Autoria da capa Sem Referência

Autoria da llustração Sem Referêncla

Técnica a ilustração XILogravura

Tradução SEm IndicAção

Versão do texto da capa Olga Belov ( para utilização da FCJA) 
edição russa, lançada pela União Soviética na vigência do regime comunista, foi a segunda selecionada. Com a participação da Rússia na Primeira Guerra Mundial e a Revolução de Fevereiro, a monarquia é substituída pela república parlamentar que deu origem ao Partido Comunista. Este partido distribuiu terras aos camponeses, transferiu o controle das indústrias a representantes operários, enfrentando várias forças de oposição. Em 1922, foi criada a União das Repúblicas Socialistas Soviéticas (URSS), que reunia os territórios antes pertencentes ao Império Russo. Em 194I, a Alemanha invadiu a URSS, e, a partir da reação russa a essa invasão, a URSS emergiu como a segunda maior potência do mundo, com seu regime socialista. Os Estados Unidos reagiram ao poder soviético e se comprometeram a impedir a expansão comunista. O mundo foi dividido em dois grandes blocos antagônicos, dando início a um processo que passou à história como guerra fria.

No período de lançamento dessa edição, havia sérios problemas entre dois aliados comunistas, a China liderada por Mao-Tse-Tung e a URSS de Nikita Kruschev, que travavam batalhas ideológicas, devido à decisão de Kruschev de não auxiliar a China a obter a bomba atômica.

Não encontramos referência à autoria da capa nem da ilustração nessa edição.

As representações dessa capa convergem para a cultura baiana e para o texto de Amado (1966, p.433), como se observa a seguir:

Chamava Gabriela de Yemanjá, dela nasciam as águas, o rio Cachoeira e o mar de Ilhéus, as fontes nas pedras. Nos raios da lua, a casa velejava no ar, subia pelo morro, partia na festa.

Perdura o deslizamento da trama política da cidade de llhéus para o percurso existencial de Gabriela. O capista colocou, no centro da composição, o rosto de uma mulher morena com cabelos compridos e uma flor alva sobre a orelha, ao lado de uma sereia com um espelho nas mãos. Esta imagem lembra a personagem 
Gabriela e a tentativa de representação do orixá lemanjá, divindade do candomblé, culto afro-brasileiro, citado por Amado. A lemanjá é representada, na Bahia, como uma sereia com um espelho nas mãos, e as suas oferendas são sempre nas cores azul e branca, já que é uma divindade que representa as águas do mar, por isso talvez o ilustrador tenha colocado uma flor de cor branca no cabelo da modelo que parece representar a Gabriela.

As sereias, como lemanjá, também representam sedução. Inicialmente, inclusive no Egito, eram consideradas divindades infernais, que se transformavam para encantar. Aparecem relacionadas às emboscadas oriundas dos desejos e das paixões. No Brasil, simbolizam, ainda, uma imaginação pervertida, um sonho insensato em vez de uma ação realizável, segundo Chevalier (200 I , p.8I4). Esses sentidos, na Bahia têm relação com a representação da sereia lemanjá, que simboliza sedução e beleza.

Na trama do romance, a Gabriela é "filha de Yemanjá", com as suas características pessoais semelhantes às do orixá, seu guia. Com esta afirmação Amado já deixa subentendido que a personagem é bela e sedutora.

No fundo da composição, veem-se, em destaque, alguns círculos com cenas de pessoas em feiras com barracas ou em frente à praia ou diante de casarios. Esses círculos estão rodeados por uma textura feita com losangos, azuis e brancos, que possuem no centro uma forma amarela que lembra o cacau, tão citado no texto do romance.

A Quarta capa possui a mesma composição artística sendo que, no centro, vê-se um abebé, o espelho que a divindade lemanjá, rainha das águas, normalmente carrega em suas mãos. A palavra espelho tem sua origem em speculum, que deu origem ao termo especulação, que significa olhar as estrelas, segundo Chevalier e Gheerbrant (200I). A simbologia do espelho é extremamente rica devido à condição de superfície que reflete, e é muito associado à tradição nipônica de revelador da verdade e da causa dos atos passados. Significa, também, a harmonia e a união conjugal, a pureza perfeita da alma, a superfície das águas, o reflexo da ação dos homens, a alma e a magia que permitem ler o passado, o presente e o futuro das pessoas. Por isso, vários sentidos podem estar associando o espelho abebé ao orixá, no sentido da trama e da ilustração da capa.

Não foi percebida nenhuma representação que pudesse ser considerada como divergente do discurso de Amado ou do discurso dos capistas brasileiros ou, ainda, da cultura brasileira. 



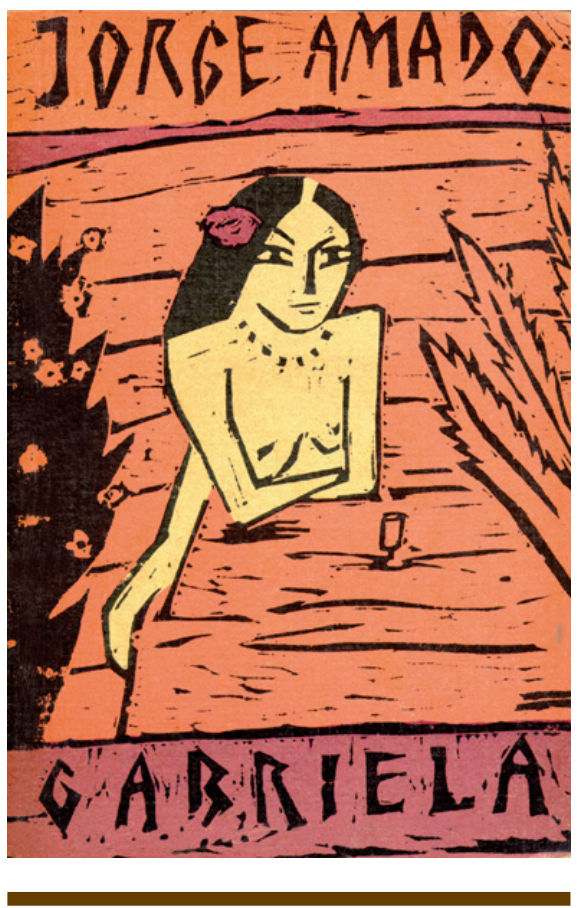

\section{Terceira Capa Estrangeira}

\section{Título Gabriela}

País Alemanha

Editora Sem ReferênCIA

Ano 1962

Autoria da capa Sem Referência

Autoria da ilustração SEm RefERÊNCIA

Técnica a ilustração XILogravura

Tradução Sem ReferÊnCIA

Versão do texto da capa Carmen Silva Medeiros ( para fins deste trabalho) 


\begin{abstract}
A
Alemanha ocupa posição central geopolítica na Europa e abriga a segunda maior população do continente. Derrotado por duas guerras mundiais, o país esteve dividido por quarenta anos em Alemanha Ocidental e Oriental, funcionando como pilar do equilíbrio geopolítico europeu durante a guerra fria. O Muro construído em Berlim por autoridades orientais em 196I, um ano antes do lançamento dessa edição, tinha como finalidade deter o fluxo de refugiados para o Ocidente. Esse Muro passou a ser o símbolo da guerra fria que esbarrou nas mais importantes tentativas de desenvolvimento econômico do bloco de países socialistas. A queda do chamado Muro de Berlim aconteceu em 1989, marcando o início da reunificação e reforçando o papel da Alemanha como país-chave no cenário mundial.

Não há referência da autoria da capa nem da ilustração dessa edição.

Essa capa traz na sua ilustração apenas uma semelhança com o texto amadiano, uma vez que a figura representada lembra uma mulher com uma flor no cabelo, num ambiente com supostas plantas floridas ao seu redor. A posição da flor no cabelo pode remeter à personagem Gabriela que costumava usar uma flor no cabelo, e a indicação de plantas por perto pode sugerir que, no ambiente dessa personagem, estavam presentes, elementos da natureza. $O$ texto das orelhas explica o subtítulo original, Cravo e Canela, que não foi citado na capa, e explica sumariamente a trama do romance, inclusive com observações críticas que convergem para a criação amadiana.

Algumas representações nessa ilustração diferem do que expressa o texto literário: a figura da mulher é bastante magra e de cor clara, o que diverge da descrição de Amado de uma personagem roliça e cor de canela. Além do mais, o título também vem fracionado, citando apenas parte do título amadiano, sem as indicações que associam a personagem à cor e ao sabor do cravo e da canela. A falta dessas indicações no título dificulta a relação entre a edição traduzida e a
\end{abstract}


primeira edição brasileira, assim como a distancia do texto original, parecendo ser outro trabalho literário. No entanto a aproxima da primeira edição francesa e da ilustração de Di Cavalcanti.

Aparecem elementos da natureza, afastando a representação da mulher da cultura urbana, racional, fazendo-a emergir em meio a plantas e flores grandes e vistosas, sugerindo regiões tropicais. 



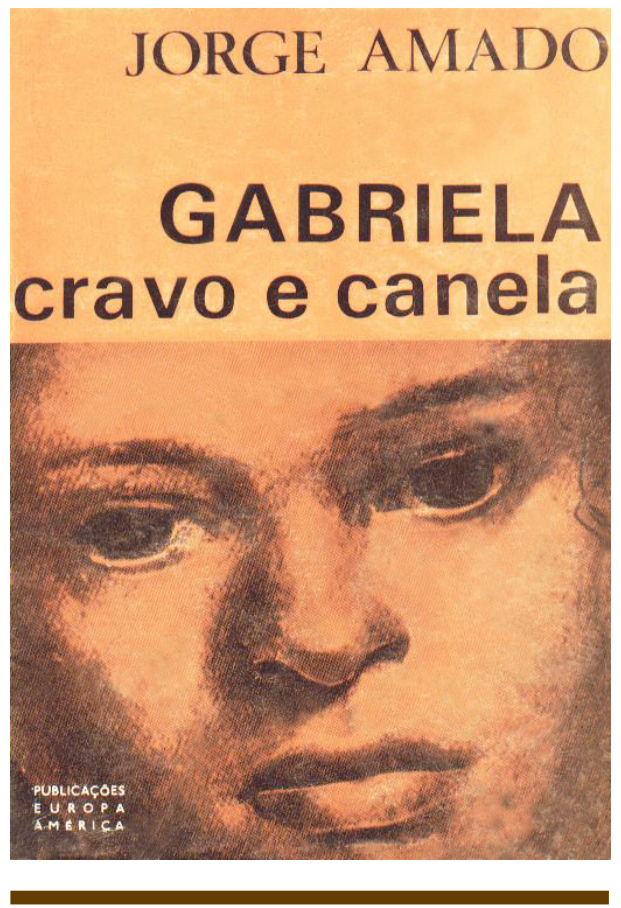

\title{
Quarta Capa Estrangeira
}

\author{
Título Gabriela, Cravo e Canela \\ País Portugal \\ Editora Publicações Europa - AmÉrica \\ Ano 1965 \\ Autoria da capa Sem ReferênCIA \\ Autoria da llustração CÂNDIDO PORTINARI \\ Técnica a ilustração PINTURA
}


$\mathrm{E}$

ssa edição foi lançada em Portugal, localizado no Sudoeste da Europa, na Península Ibérica, e que formou um vasto império colonial englobando o Brasil e parte da África e da Ásia, responsáveis pela difusão da língua portuguesa no mundo.

Na década de 60, quando foi lançada essa edição, havia uma recusa em conceder independência às colônias africanas de Portugal, o que estimulava os movimentos guerrilheiros de libertação. Posteriormente, a decadência econômica e o desgaste com a guerra nas colônias africanas provocaram descontentamento nas forças armadas e o enfraquecimento do governo totalitário português. Então, em 1974, eclodiu a Revolução dos Cravos que promoveu a redemocratização do país. A população festejou o fim da ditadura distribuindo cravos - a flor nacional aos soldados rebeldes. $O$ governo passou a ser dominado pelo Movimento das Forças Armadas, fortemente influenciado pelo socialismo. Em 1975, porém, o governo passou a ser liderado por um triunvirato de generais conservadores e somente em 1995 os socialistas venceram as eleições parlamentares e voltaram a assumir o governo.

O ilustrador dessa capa é Cândido Torquato Portinari, brasileiro nascido em Brodósqui, São Paulo, em 1903. Pintor e desenhista, filho de imigrantes italianos, começou a pintar ainda criança, trabalhando na restauração de adornos de igrejas da sua cidade natal. Em 1918, mudou-se para o Rio de Janeiro e passou a frequentar a Escola Nacional de Belas-Artes, onde estudou com Batista da Costa e Lucílio de Albuquerque. Quando exibiu alguns dos seus trabalhos, passou despercebido, inclusive numa exposição coletiva realizada no ano de 1922, que marcou o início do modernismo. Em 1928, com o retrato de Olegário Mariano, foi premiado com uma viagem à Europa onde viveu dois anos. Voltando ao Brasil, no ano de 1931, afastou-se de vez, segundo alguns críticos, da tradição acadêmica, executando trabalhos de acordo com o que vira na França, Itália e Inglaterra. Em Brodósqui, realizou sua primeira experiência mural no ano de 1933, com a obra 
Fuga para o Egito, feita na parede da casa paterna. Em 1934, realizou a obra Café, que no ano seguinte recebeu menção honrosa da Fundação Carnegie dos EUA e marcou o início de um período de intensa atividade. Influenciado pelos muralistas mexicanos, começou a elaborar, no Brasil, painéis para o Ministério da Educação, trabalho que durou cerca de oito anos, sendo concluído em 1945. A partir da década de 40, aderiu ao Expressionismo, de caráter social, e destacou-se com as obras Emigrantes, Menino Morto e Enterro na Rede. Na mesma década, executou a obra Via Crucis, na Igreja da Pampulha, em Belo Horizonte, Minas Gerais e pintou vários quadros com o tema "meninos de Brodósqui". A partir de 1948, compôs uma série de obras com temas históricos, como Primeira Missa no Brasil (1948) e Tiradentes (1949) e, na década de 50, concluiu o gigantesco painel Guerra e Paz, que se encontra no edificio-sede das Nações Unidas em Nova York, EUA.

Além de ter elaborado muitas obras com temas de cangaceiros, Portinari foi muralista emérito, comparado frequentemente com os muralistas mexicanos Rivera, Orosco e Siqueiros, pois sua obra demonstra um claro sentido político. Mostrou seus trabalhos no Brasil, como também no exterior, sendo apontado pela crítica como um dos principais representantes da arte brasileira, o artista mais importante da América do Sul e, inclusive, um dos artistas de maior repercussão internacional. Faleceu em 1962, no Rio de Janeiro, deixando uma grande quantidade de trabalhos de temas regionais, históricos, de cenas religiosas, além de muitos retratos, que continuam sendo utilizados como ilustração como o pormenor usado nessa capa.

A ilustração escolhida pelo capista converge para o discurso amadiano, já que é um pormenor de um trabalho artístico que enfoca um rosto feminino jovem, com traços e cor que lembram a mulata brasileira, e a cor da impressão é amarronzada como a cor do condimento canela a que Amado se refere no título desse romance.

O fato de essa imagem escolhida pelo capista para ilustrar a capa ser um trabalho artístico executado por um brasileiro legitima o seu discurso, ao tempo em que demonstra, para os observadores, que quem representa e demonstra 0 título acima conhece e sabe sobre a cultura de origem do brasileiro. Nessa edição, é possível perceber que quase todos os signos possuem forte relação com o texto do romance e com a Bahia, e não há necessidade de intermediações, talvez pela proximidade do Brasil com Portugal, quanto ao idioma e quanto a alguns costumes, posto que o Brasil foi colonizado por Portugal, sendo natural que características do povo colonizador, por questões históricas, tenham permanecido na Bahia, local 
onde se passa a estória. Além do mais, o autor da ilustração é um brasileiro que trabalhou muito com a regionalidade brasileira, os habitantes do interior ou trabaIhadores. $O$ pormenor escolhido para ilustrar a capa demonstra a fidelidade na representação desse artista sobre o hibridismo do povo com o qual convivia.

A divergência percebida é apenas quanto ao título no qual não consta a expressão cravo e canela como epítetos, além da vírgula depois do nome Gabriela. Talvez esta omissão se explique por falta de revisão da editora, o que demonstra pouco cuidado com o trabalho do autor literário. 

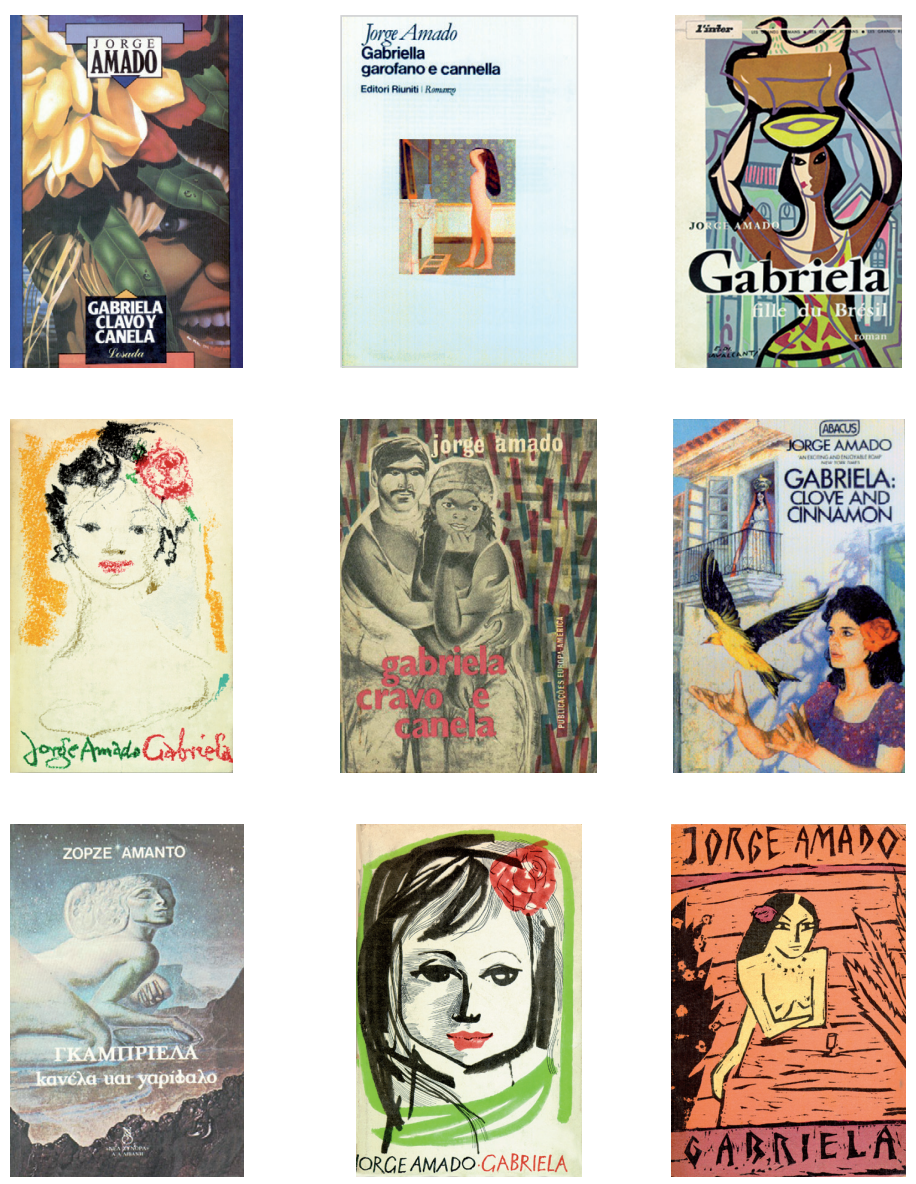



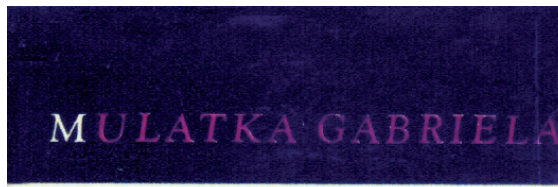

\section{Quinta Capa Estrangeira}

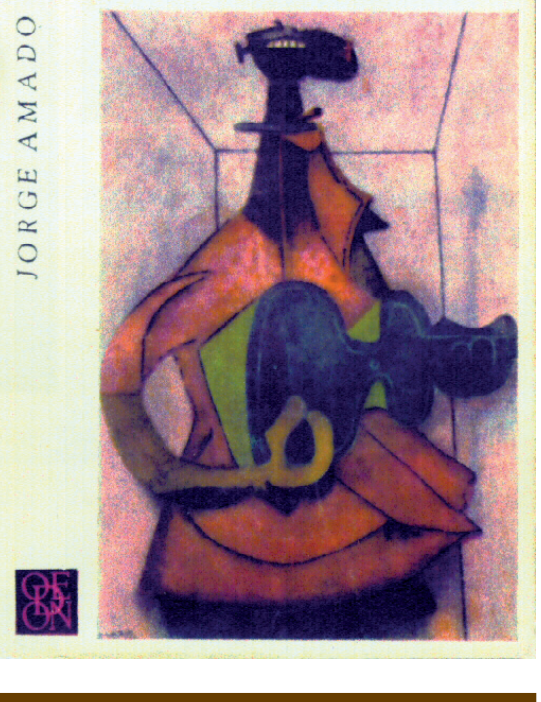

Título MulatKa Gabriela

País TCHeCOSLOVÁQUIA

Editora Odeon

Ano 1967

Autoria da capa Sem ReferênCIA

Autoria da llustração Rufino TAMAYO

Técnica a ilustração PINTURA

Tradução ZDENEK HAMPL

Versão do texto da capa Bohumila Araújo ( para fins deste trabalho) 
ssa edição foi feita na Tchecoslováquia ainda sob o regime comunista. No início dos anos 90, com a chamada Revolução de Veludo, dividiu-se e transformou-se em República Tcheca e Eslováquia. A República Tcheca é uma das economias mais desenvolvidas do extinto bloco socialista, destaca-se pela produção de automóveis, cerâmicas, tecidos e cervejas, e destina a maior parte das suas exportações para a União Européia.

Com o golpe de Estado dado pelos comunistas em 1948, a Tchecoslováquia ficou sob a influência da União Soviética.

$\mathrm{Na}$ década de 60, quando foi lançada essa edição, começaram fortes manifestações por reformas democráticas, surgindo o primeiro movimento - a Primavera de Praga -, reprimido violentamente pela Rússia em 1968. Esse episódio foi marcado pelo emprego das tropas do Pacto de Varsóvia que invadiram a Tchecoslováquia para reprimir os movimentos pró-democracia no país.

Em 1989, com as reformas pacíficas da Revolução de Veludo, tomou corpo a campanha para separação dos dois países, aprovada em 1992. Em 1993, surge a República Tcheca.

O autor da ilustração escolhida pelo profissional que fez essa capa é o pintor Rufino Tamayo que nasceu em Oxaca, no México, em 1917. Tamayo estudou Belas Artes na Academia de São Carlos e na Universidade do México. Trabalhou no Departamento de Desenhos Etnográficos do Museu Arqueológico Nacional do México, e os desenhos que elaborou, nesse trabalho, são considerados por alguns críticos como de grande influência na sua técnica artística. Com a proposta de explorar a arte moderna, mudou-se para Nova York em 1924, onde descobriu o trabalho de outros artistas tais como Rouault, Brancusi e Matisse, aprendendo novas técnicas e conhecendo outros processos que ajudaram, no seu trabalho, a reconhecer o valor da pesquisa. 
Em 1926, teve o primeiro encontro com o grande muralista mexicano Diego Rivera e, posteriormente, com outros muralistas que, assim como Rivera, eram considerados artistas de temática nacionalista, como José Clemente Orozco e David Alfaro Siqueiros. Enquanto os trabalhos artísticos desses muralistas eram exaltados pelos críticos, o trabalho de Tamayo era confinado, pois revivia a antiga civilização mexicana. Por não ter provocado uma simpática reação nos adeptos da revolução mexicana, tornou-se um renegado pelos mexicanos contemporâneos. Não era considerado como um grande profissional, pois era distante da política e, apesar de com alguns dos seus trabalhos ter abordado temas nacionalistas, preferia a utilização de temas cósmicos, folclóricos e, principalmente, a solidariedade da vida diária.

Observador das tradições artísticas mexicanas, refletia em seus trabalhos a herança hispânica, e suas pinturas também demonstram influência do Cubismo e do Expressionismo.

Tornou-se professor da Escola Nacional de Artes, em 1928, mas um maior reconhecimento de Tamayo surgiu após 1930, quando se destacou ao ser inserido na publicação Contemporary Artists of Mexico. A partir desse momento, passou a expor suas pinturas regularmente em Nova York, aumentando esse reconhecimento com a exposição das suas pinturas na Galeria de Belas Artes em Paris, no ano de 1940. Nos anos 50, empreendeu uma série de viagens pela Europa e fez parte do grupo de pintores muralistas.

Mitos, fábulas e esculturas pré-colombianas influenciaram o trabalho desse artista que destacou, também, seu especial interesse pela representação da figura feminina. A sua pintura tem como características a forte influência da arte popular mexicana com monumentalidade, toques largos do pincel, supressão de detalhes e cores expressivas. Considerado, por alguns críticos, como um pintor figurativo, pintou uma série de retratos e abordou, na maioria das vezes, temas da vida da aldeia mexicana ou da pobreza urbana.

Considerado um dos melhores pintores contemporâneos, seus trabalhos são reconhecidos em todo mundo, como Nova York, Tóquio e Paris, onde possui trabalhos expostos em alguns museus. Faleceu em 1991, quando estava executando uma série de litografias, deixando apenas oito dessas gravuras completas e assinadas.

Em 1999, foi celebrado com honras o aniversário de 100 anos de nascimento desse artista, com muitas atividades e no México, principalmente em Oxaca. Esse ano foi denominado "O ano de Rufino Tamayo" 
Somente pelo nome Gabriela e a caracterização da mulata, é possível associar o livro ao texto de Amado, sendo que pode parecer para o leitor estrangeiro um outro trabalho literário, já que se trata de um novo título -Mulata Gabriela. Nos textos impressos nas orelhas dessa capa, há um resumo crítico do romance e algumas informações sobre outros romances de autoria de Amado, assim como um breve resumo biográfico do autor e do ilustrador. As informações dadas nesses textos demonstram uma convergência aos discursos de Amado, à sua biografia e à biografia de Tamayo.

O título diferente (Mulata Gabriela) demonstra o enfoque escolhido pelo capista ou pela editora, que é enfatizar ou focalizar o tipo físico e racial da personagem amadiana. A ilustração escolhida pelo capista para representar esse título, é uma tela do pintor mexicano Tamayo, que demonstra uma imagem bastante diferente do que descreve Amado em seu texto. A tela possui o título $\bigcirc$ seresteiro e mostra um personagem de difícil identificação, um misto de figura futurista e antepassada, que lembra uma figura deformada, com uma suposta viola. Mesmo considerando as peculiaridades do traço do artista, torna-se distante a relação dessa ilustração com o personagem amadiano e também impossível uma articulação com o título. Amado (1966, p.383), quando descreve o Terno de Reis, cita alguns instrumentos musicais e refere-se à dança e à música, o que pode ter provocado alguma relação:

Por volta das onze horas, quando já o sereno se reduzira a umas poucas pessoas - há muito Glória se retirara e com ela o coronel Coriolano - , ouviu-se, vindo da rua, música de cavaquinhos e violões, de flautas e pandeiros. Evozes a cantar cantigas de reisado. Gabriela elevou a cabeça. Enganar-se não podia. Era o terno de Dora.

As pastorinhas com as lanternas, Miquelina com o estandarte. Nilo, o ex-marinheiro, com um apito na boca, comandava o cantar e o dançar. Da praça Seabra, na mesma hora, vinham o boi, o vaqueiro, a caapora, o bumba-meu-boi. Dançando na rua.

Se a representação foi provocada por essa parte do texto de Amado, demonstra falta de conhecimento do que seja essa manifestação popular brasileira, pois é bastante divergente do que normalmente aparece nas apresentações dos Ternos nas festas baianas. Por conseguinte essa imagem passa a ser uma nova metáfora.

Mas, para os leitores ou apenas observadores da capa que não tenham tido nenhum acesso à cultura brasileira, ou a uma leitura sobre a diversidade cultural 
e étnica da América Latina, o reconhecimento do discurso amadiano poderá ser feito de forma equivocada, distorcida, pois o que essa imagem evoca pode estar ligado ao imaginário do capista através de uma relação pessoal e bastante singular. Talvez essa articulação tenha sido feita, também, por região geopolítica - a América Latina, ou representação/expressão artística de uma região considerada equivocadamente com características/marcas/identidades semelhantes ou únicas. 

Jorge Amado

Gabriella garofano e cannella

Editori Riuniti | Romanzo

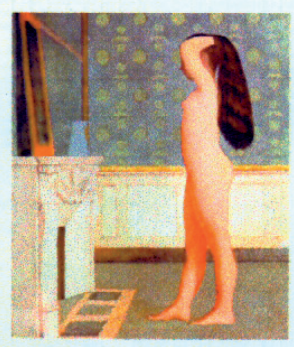

\section{Sexta Capa Estrangeira}

Título Gabriela, Garofano e Cannella

País ITÁLIA

Editora RIUNITI

Ano 1982

Autoria da capa Sem Referência

Autoria da ilustração BALTHus

Técnica a ilustração PINTURA

Tradução GIovanNı PAsserı

Versão do texto da capa SILVIA LA REGINA ( para fins deste trabalho) 


\begin{abstract}
A
Itália ocupa a Península Itálica, no Sul da Europa, e algumas ilhas do mar Mediterrâneo. Sua religião dominante é o cristianismo. Na Antiguidade, essa região foi responsável pela difusão da língua e da cultura latina pelo mundo. Roma, sua capital, preserva importantes monumentos desse período. A sede da lgreja Católica, instalada em seu território, tem forte participação na vida nacional. Durante o período do Renascimento, o país tornou-se centro de irradiação cultural e científica.
\end{abstract}

Em 1982, quando essa capa foi lançada, havia uma séria disputa política e ações de terrorismo em torno do governo envolvido em acusações de corrupção no país. Dois anos depois, assumiu o primeiro governo socialista.

Novamente, uma tela de expressivo pintor vai ser selecionada para ilustrar a capa e, mais uma vez, o autor é de uma cultura bem diversa da cultura do escritor brasileiro. A ilustração escolhida para essa capa é de Balthazar Klossowski de Rola, que assinava Balthus, artista plástico polaco, filho de um crítico de arte e de mãe pintora. Começou a pintar com 16 anos, mas como autodidata porque o pintor Bonnard, amigo do seu pai, dissuadiu-o de estudar numa escola de pintura. Desta maneira, o jovem, aprendendo a técnica, continua a recopiar as obras da Renascença e de Poussin, o seu pintor preferido. Fez sua primeira exposição em 1934 em Paris, com pinturas sobre a vida cotidiana de interiores, como também alguns retratos como o de Miró e a sua filha. Alguns críticos ressaltam que estes retratos aproximam-se do realismo fantástico de alguns pintores alemães como Gosz, Dix e Berckmann, e do grupo francês "Forces Nouvelles". Seis anos depois da exposição inaugural da sua carreira, Balthus afirmou-se com um estilo denominado pela crítica de "erotismo intimista", que enfocava ninfetas em interiores, adormecidas, cândidas ou perversas, passivas ou angustiadas. Costumava afirmar que os seus personagens eram seres puros e sem idade, pois eram, na sua maioria, crianças, num misto de perversão e ingenuidade. Considerado desenhista de grande 
precisão, trabalhava com várias técnicas, retomando o mesmo tema e variando a composição. Dedicou-se às obras em série executando $\bigcirc$ Jogo de Cartas em 1944-45, 1948-1950, 1973; O Sonho em 1955-56, 1956-57 e as Três Irmãs em 1959-64, 1964-65 e 1965. Era conhecedor da história da arte, e a sua pintura denota influência da pintura oriental, mas dizia que a arte era um ofício, considerando-se apenas um trabalhador.

Convidado por André Malraux, em 1961, passou a dirigir a Academie de France, Ville de Médicis, em Roma, cargo que ocupou até o ano de 1978. Viu a sua carreira consagrada quando expôs seus trabalhos nos grandes centros de arte contemporânea: Centro George Pompidou, em Paris, o Metropolitam Museum de Nova York e o Museu de Arte Contemporânea de Chicago. Destacou-se com prestígio nas exposições Documenta VI, em Kassel, na Alemanha, e na Bienal de Veneza em 1995. A sua vida está envolta em mistérios e controvérsias que resultam também da autoexclusão a que se submeteu. Faleceu aos 92 anos no seu chalé, em Rossiniere, na Suíça, onde viveu muitos anos em reclusão, com a sua esposa Setsuko.

Suas telas são consideradas como dotadas de uma geometria rigorosa, cujos ambientes demonstram uma aura de mistério. Cedia suas obras apenas para amigos, mas deixou cerca de 300 telas. Era uma pessoa discreta, silenciosa e se considerava como pertencente ao século XIX, pois era amante da privacidade e da intimidade, por isso poucas vezes se deixou fotografar. Ao falecer, deixou três filhos, fruto de dois casamentos, e uma obra das mais bem cotadas do mundo, algumas delas já tendo atingido recordes mundiais.

A obra que ilustra a capa dessa edição italiana de Gabriela, Cravo e Canela chama-se Nudo davanti al camino (Nu em frente da lareira) e foi feita no ano de 1955.

Essa capa italiana traz como reflexo do texto amadiano o cuidado com a tradução do título, que é fiel ao título original do romance. Também o texto crítico, exposto na quarta capa, mantém essa fidelidade quando trata resumidamente sobre o que acontece na trama.

A imagem que ilustra a capa mostra uma menina, branca, de perfil que está nua diante de uma lareira, arrumando o cabelo comprido. A lareira é símbolo da vida em comum, segundo Chevalier e Gheerbrant (200 I, p.536-537), da vida da casa e da união do homem e da mulher, do amor, da conjunção do fogo com o seu receptáculo. Representa o centro da vida, a porta para a aproximação entre as 
pessoas, por seu calor e sua luz. Sendo assim, o sentido da lareira pode lembrar o texto amadiano quando parece querer simbolizar Gabriela, jovem recém-chegada a llhéus, diante da vida que iria iniciar, a vida a dois, a vida afetiva com Nacib, como se estivesse no momento em que o fogo da menina fosse acender e aquecer o seu interior afetivo. Por outro lado, pode não ter nenhuma relação com o texto do romance e, talvez, insinue para a Itália uma cena de erotismo perverso, em que a menina nua pode ser, inclusive, um tabu para uma sociedade católica.

Acima da lareira, Balthus imprime um vaso, que é símbolo de contingente, tesouro, reservatório da vida, força secreta e receptividade, pela sua abertura superior. Segundo Sant'anna (1993, p.91) a mulher é um vaso que contém outro vaso, referindo-se às suas partes sexuais. $\bigcirc$ espelho impresso junto ao vaso, além dos vários sentidos já citados neste trabalho, pode estar representando a reflexão de quem olha para si mesmo, isto é, as reflexões da mulher que está em frente desse espelho.

A representação dessa menina de pele branca, nua, em frente à lareira e ao espelho, como se estivesse arrumando os cabelos, distancia-se das características da Gabriela. $O$ estilo e os tons do papel de parede e pintura do quarto lembram ambientes sóbrios, decoração de ambientes de uma região de temperatura fria, diferente dos ambientes internos das casas brasileiras, da zona tropical como a cidade de Ilhéus, e diferente também das classes sociais descritas no livro. A menina representada lembra uma criança européia, de tez clara, o que parece mais próximo do ambiente e da criança do país do público-alvo. A escolha dessa pintura como ilustração do romance pode ter sido porque uma menina em posição sensual e provocante sexualmente demonstraria o interesse do capista quanto ao enfoque que gostaria de evidenciar na embalagem-capa. 

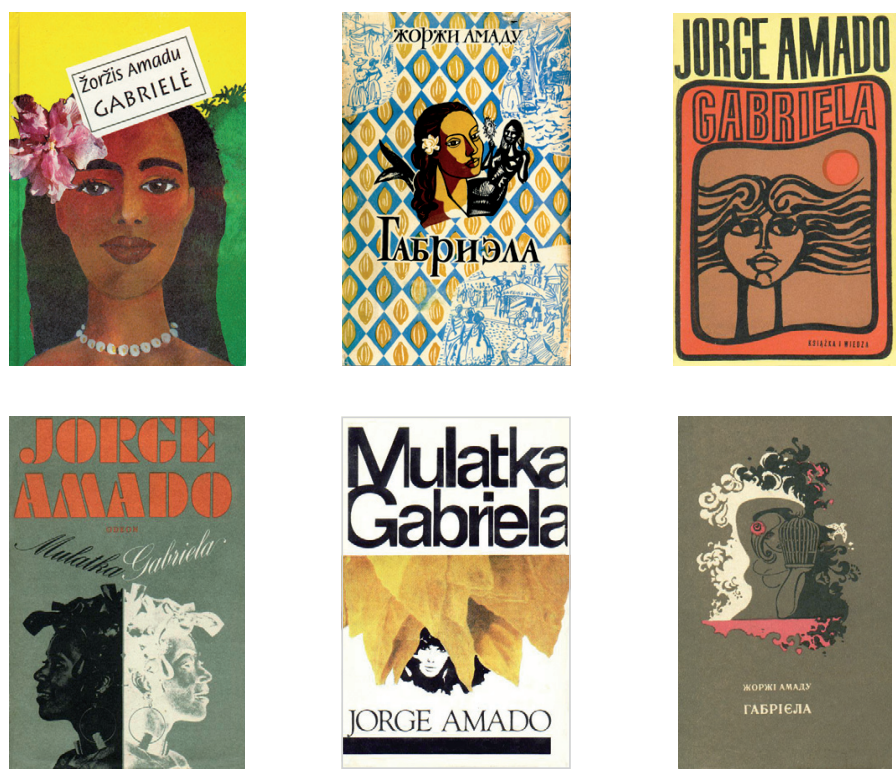



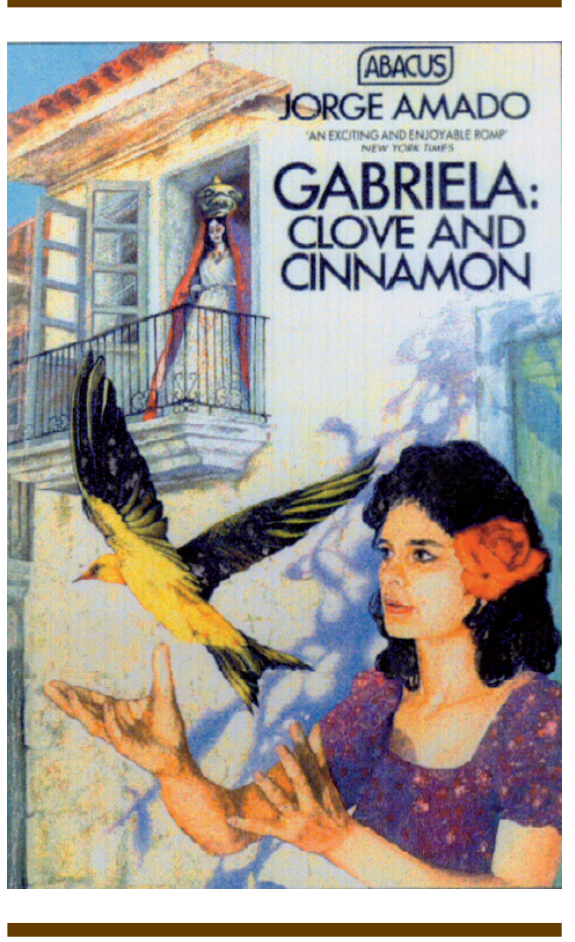

\section{Sétima Capa Estrangeira}

Título Gabriela: Clove and Cinnamon

País INGLATERRA

Editora ABacus

Ano 1983

Autoria da capa Sem Referência

Autoria da llustração Sem ReferênCIA

Técnica a ilustração PINTURA

Tradução Sem RefERÊNCIA

Versão do texto da capa Gerald MORRIs ( para fins deste trabalho) 
A

Inglaterra, como país imperialista, com muitas colônias na região tropical, na Ásia e na África, tem maior contato com a diferença, a alteridade. A distribuição étnica da sua população, atualmente, é resultado direto da transformação econômica, vinda do século passado, por ocasião da revolução industrial e do colonialismo. A história de invasões e conquistas tornou peculiar a vida política social inglesa, que possui, ainda, 14 dependências externas que no passado foram colônias britânicas e, hoje, gozam de autonomia em assuntos internos.

Esse país tem a sua origem nos anglo-saxões, tribo germânica que se estabeleceu na região no século $\mathrm{V}$. $\bigcirc$ idioma originário e oficial desse país é o inglês, uma das línguas mais faladas do mundo, além do gaulês e do gaélico, devido, em grande parte, ao período da colonização. A Inglaterra é considerada país do "primeiro mundo" ou "velho mundo", uma terra de castelos e de reinados. Mas, apesar do desenvolvimento econômico, diversas cidades da Inglaterra sempre foram sacudidas por confrontos raciais estimulados pela extrema direita, envolvendo os imigrantes asiáticos.

Na década em que foi lançada essa edição, especialmente início dos anos 80 , a maior parte do setor público estava sendo privatizada, os sindicatos se enfraqueciam e o desemprego crescia. Paralelamente, a população de países póscolonialistas passava a procurar viver na metrópole e a integrar as academias universitárias de onde discutiam o desmonte do sistema imperial através das teorias e categorias novas, conflitantes com o paradigma moderno. No mesmo período, esse país descobriu o petróleo no Mar do Norte, e, em 1983, a Inglaterra fortaleceu-se com a vitória na Guerra das Malvinas.

Não foram encontradas referências, nessa edição, sobre a autoria da capa e da ilustração.

Nessa capa, vê-se uma imagem de mulher de tez clara, traços fisionômicos delicados, nariz e boca pequenos, cabelos ondulados, mas lembrando a mulher 
latino-americana, ou das ilhas asiáticas, com uma flor vermelha na cabeça, um vestido estampado com pequenas flores rosas em fundo violáceo. Esta mulher está representada com as mãos abertas, libertando um pássaro amarelo. Esses elementos icônicos sugerem ou indicam a personagem Gabriela, no trecho que trata da libertação do pássaro - um sofrê -- recebido de presente do Nacib, como narra Amado (1966, p.260-26I):

Numa gaiola, um sofrê partia num canto triste e mavioso. Belo e inquieto, em negro e amarelo, não parava um instante. Seu trinado crescia, era doce de ouvir. (AMADO, 1966, p. 260-26I).

Passarinho preso em gaiola não quisera jamais. Dava-lhe pena. Só não dissera pra não ofender seu Nacib. Pensara lhe dar um presente, companhia pra casa, sofrê cantador. Canto tão triste, seu Nacib tão triste. Não queria ofendê-lo, tomaria cuidado. Não queria magoá-lo, diria que o pássaro tinha fugido. Foi pro quintal, abriu a gaiola em frente à goiabeira. O gato dormia. Voou o sofrê, num galho pousou, para ela cantou. Que trinado mais claro mais alegre! Gabriela sorriu. O gato acordou. (AMADO, 1966, p.256).

O pássaro, em algumas culturas, representa a força que inspira o homem a descobrir discursos sábios e fazer previsões. Simboliza, ainda, o desejo humano de libertar-se, exatamente o sentido que Ihe foi atribuído nesse texto amadiano e nessa ilustração, além de se inserir na natureza.

A flor vermelha no cabelo, a ação da mulher representada, o vestido estampado e a forma e as cores do pássaro também podem ser associados ao mesmo fragmento da narrativa do romance. A direção do voo do pássaro na imagem plástica leva a uma janela de uma casa de arquitetura colonial que provoca, no observador, uma relação com os velhos casarios mediterrâneos ou ibéricos, modeladores das casas da cidade de llhéus narrada pelo escritor. Na sacada dessa casa, observa-se a representação de uma mulher com vestes longas de cor branca e olhar lânguido, que pode estar simbolizando a personagem de um rondó, cantado em prosa e verso por alguns personagens frequentadores do bar do Nacib. Eles se referiam a uma mulher pura, sem pecado, já que no texto desse rondó a personagem Ofenísia, apaixonada pelo imperador, nunca se entregou aos caprichos do amor. Pode também se associar a uma divisão de classes - a senhora e a mulher popular ou, ainda, a uma representação religiosa. 
A romântica Ofenísia morreu tísica e virgem, no Solar dos Ávilas, saudosa das barbas reais. (AMADO, 1966, p.48).

Inclusive, essa personagem está vestida de branco, o que pode querer reforçar sua pureza e castidade, não apenas pelo sentido dessa cor no mundo ocidental cristão, como também pela presença do rosário em suas mãos. Além disso, essa mulher está com os cabelos cobertos, lembrando a representação religiosa ou a antiga realeza, ao contrário da mulher que representa a Gabriela, cujos cabelos estão soltos, associando-se ao poder sexual e à paixão ou à classe social mais baixa. Admite-se que existe uma relação assimétrica entre a imagem em primeiro plano e a de fundo.

A mulher que está em segundo plano, acima, imprime a idéia de lugar inacessível, como figura feminina que representa o ideal de beleza e de comportamento social feminino (na sociedade ilheense) e está representada como quem detém o poder, pela presença da coroa e do manto vermelho. A suposta Gabriela, entretanto, está na rua, fora de casa, deixando perceber a diferença marcante entre as duas personagens: a "santa mulher", que não foi contaminada pelos prazeres do sexo, idealizada para esposa e mãe no imaginário social (ilheense), por isso desejada e perfeita, enquanto Gabriela é a mulher livre que se deixa levar pelos instintos.

A mulher na sacada está representada com um manto vermelho, o que faz parte dos atributos reais e simboliza, para quem veste, segundo Chevalier e Gheerbrant (200I), estar próximo dos Deuses e, consequentemente, separada das tentações terrenas e dos instintos carnais. Vestir o manto é assumir a dignidade da qual o manto é o emblema. Assim também, a presença da coroa na imagem, ainda segundo os mesmos autores, reforça esse sentido quando significa valores que sobrepujam a cabeça de quem a utiliza, isto é, dá a essa pessoa um dom vindo de cima. A coroa une a pessoa que a está usando com o divino. Simboliza a dignidade, o poder e a iluminação.

Nas mãos dessa mulher, há um rosário amarelo, que também é um atributo das divindades, configura o cristianismo e, por estar representado em amarelo, lembra o ouro, um metal nobre a que somente poucos têm acesso. Ainda nessa representação, percebe-se claramente o interesse do capista e do ilustrador em demonstrar o título com uma ilustração que diferencia dois tipos de mulheres: a que tem o poder, pura santa e intocável, com características da raça branca, 
possivelmente da mulher inglesa; e a que está junto à natureza, com características da mulher latina, num gesto que, segundo a cinésica, evidencia submissão, bondade e a impressão de uma pessoa não ameaçadora, o que o gesto de libertação do pássaro vem reafirmar.

A representação da capa diverge do que expressa o texto amadiano: a imagem de mulher que parece representar a Gabriela, de pele branca e traços fisionômicos de uma mulher latina. A figura de mulher da sacada, de capa vermeIha e coroa, pode estar relacionada com a rainha, uma mulher de classe social mais alta e que detém o poder para os ingleses. Aqui, também diverge do texto amadiano, que não aborda esse aspecto. Esse vestuário medieval aristocrático, que demonstra nobreza, honra e superioridade, não se associa às vestes da personagem cantada no rondó citado no romance.

Também diverge quanto ao título: foi colocado um epíteto e depois da palavra Gabriela, em vez da vírgula, como expressou Amado, dois pontos. $\bigcirc$ uso da vírgula, além de demonstrar uma pausa, pode estar demonstrando a omissão do verbo "cheirar", enquanto os dois pontos significam que será feita uma citação. Isso demonstra não somente uma divergência, como também uma falta de cuidado com o registro original e uma falta de respeito ao trabalho do autor literário.

Alem disso, abaixo do título, talvez por ser uma edição popular, foi colocada a citação do jornal New York Times: "Um excitante e agradável divertimento", esta última palavra expressa pelo termo romp, que pode significar também divertimento infantil, podendo esta citação ser considerada como divergente porque esse romance, não é uma literatura indicada para "lazer infantil" longe, portanto, de atribuir uma qualificação real ao livro e, à obra amadiana. Observa-se que a técnica ilustrativa usada na capa, era muito usada para livros infantis no período desse lançamento, na Inglaterra, o que pode ter sido feito, para associar esse romance às publicações para a faixa etária de menor idade, exatamente pela dificuldade de entendimento do capista quanto ao sentido dado por Amado a esse título. Provavelmente, as modificações no texto amadiano, provenientes da tradução, talvez tenham também contribuído para essa diferença de sentido. 



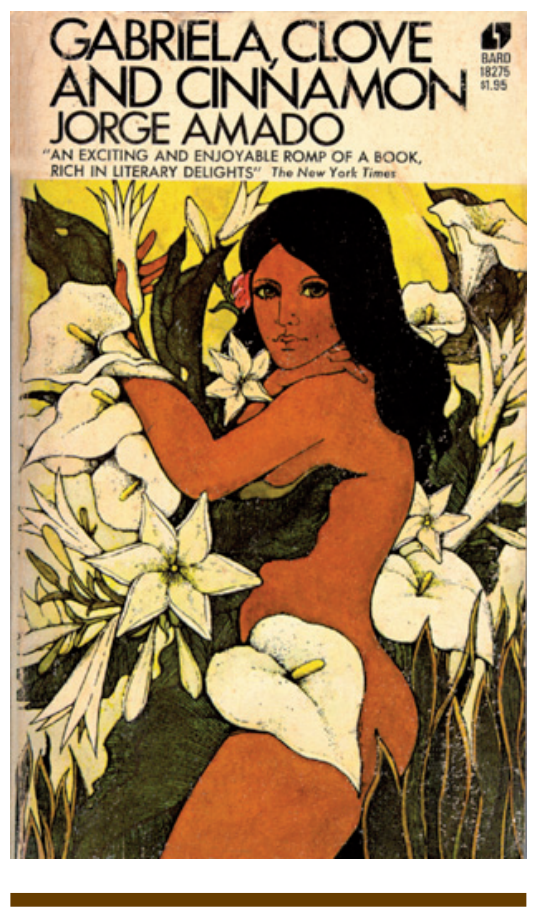

\section{Oitava Capa Estrangeira}

Título Gabriela Clove and Cinnamon

País Estados Unidos

Editora Avon Books

Ano 1988

Autoria da capa Sem Referência

Autoria da llustração Sem ReferênCIA

Tradução James TAYLor e William Grossman

Versão do texto da capa Lícia PedreIRA

( para fins deste trabalho) 
Os

Estados Unidos da América possuem o quarto território mais extenso do mundo com área de 9.372 .614 km², sendo banhados pelos Oceanos Pacífico e Atlântico. $\bigcirc$ país teve sua origem na região das 13 colônias inglesas. No fim do século XV, a América do Norte era habitada por indígenas quando Cristóvão Colombo chegou ao novo mundo. No entanto, os EUA têm uma história de extermínio dos povos indígenas e de discriminação racial, em especial com os negros e hispânicos de origem latino-americana, comunidade que mais cresceu no país, na década de 90 . Os recursos naturais e as possibilidades econômicas atraíram milhões de imigrantes nos séculos $X I X$ e $X X$ para essa região e que, segundo alguns autores, ajudaram a construir a identidade nacional.

Na década de 80, período do lançamento da edição, tinha sido eleito o presidente George Bush, ex-vice-presidente na gestão anterior, que, ao entrar no governo, continuou a política de reaproximação com a URSS até a dissolução do bloco soviético em 1991.

Ainda hoje, o país se destaca como o principal pólo de imigração internacional. Sua cultura e estilo de vida têm grande influência global por meio do cinema, da literatura, da música e da TV. O PIB é de, aproximadamente, US\$ 9, I 5 trilhões, superando o da Alemanha e do Japão somados. Sozinha, essa nação tem posição central na economia e responde por mais de um quarto da população mundial, e tem elevado padrão de vida e uma das maiores rendas per capita do mundo. As religiões são o catolicismo e o protestantismo, que é dominante. A forma de governo é a República Presidencialista. Na sua população de hoje, mesmo com a maioria de euro-americanos, percebe-se grande quantidade de latinos, muitos deles em situação irregular no país.

Não há, na capa dessa edição, referência à autoria da capa nem da ilustração.

Essa capa americana reflete (com desvios) a obra amadiana, quando representa a mulher de olhos verdes, com cabelos soltos, como a personagem Gabriela 
do texto. A ilustração traz, em primeiro plano, uma mulher de tez mestiça com traços latino-americanos no meio de um jardim, ou de uma mata florida, junto à natureza, inscrevendo-a no imaginário da América Latina (primitivismo e instinto) sobre a mulher, sexualmente permissiva, sem limites e sem noção do bem e do mal. As flores, segundo Chevalier e Gheerbrant (200 I), podem também significar instabilidade e caráter fugitivo da beleza e, ainda, o desejo carnal, todo o âmbito do erotismo, da força vital, da alegria de viver, o paraíso. Além disso, as espécies das flores, lírio e copo-de-leite, parecem ser propositalmente escolhidas, já que o lírio representa a pureza na religião católica e o copo-de-leite tem um pistilo que lembra um símbolo fálico - o pênis masculino. O ilustrador, inclusive, reforça essa idéia quando coloca essa flor em frente à região pubiana da mulher. $O$ sentido dessas duas flores pode estar relacionado à dubiedade de comportamento da Gabriela, entre a ingenuidade e a sexualidade e a sedução, como se vê no texto amadiano.

Ao representar a mulher, suposta Gabriela, o capista cobriu-a com flores para que a nudez não fosse explícita. Talvez isso tenha sido feito para que, provavelmente, a capa não fugisse aos padrões comportamentais do público-alvo, evitando uma censura prévia dos consumidores ao identificar seu autor com a América Latina e a visão de permissividade que parece permear o imaginário norte-americano quando se refere aos latinos. Acima da ilustração, vem uma citação da crítica publicada no jornal New York Times, a mesma usada pela edição inglesa, que se refere a essa obra como divertimento leve, de lazer infantil, o que é mais uma distorção. 

GABDIEIA

CLAVOYAMHA

Jorge Amado

Mianza fulitorial

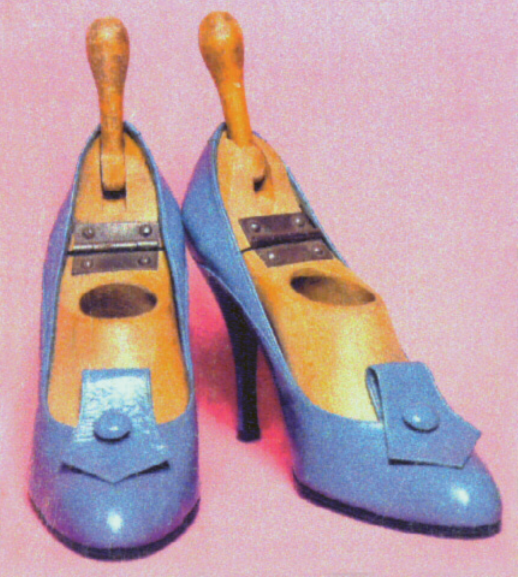

Nona Capa Estrangeira

Título Gabriela Clavo y Canela

País Espanha

Editora Alianza Editorial

Ano 1994

Autoria da capa Daniel GIL

Autoria da llustração Sem ReferênCIA

Técnica da ilustração FotografiA

Tradução Haydée Jofré Barroso

Versão do texto da capa Sônia Regina Caldas ( para fins deste trabalho) 


\begin{abstract}
A
Espanha ou Reino da Espanha ocupa um território de 505.954 km², cerca de 80\% da Península Ibérica, no Sudoeste da Europa, sendo banhada pelo Mar Mediterrâneo e pelo Oceano Atlântico. Sua população é formada por povos de várias origens - castelhanos, catalães, galegos, andaluzes e bascos, que vivem em regiões diferentes. Somente no final do ano de 1978, essas regiões passaram a ter autonomia e a ser consideradas nacionalidades históricas com língua e cultura próprias, provocando, em seu povo, uma consciência regionalista inclusive pelos diferentes idiomas. A Espanha é um país de forte tradição católica e de grande fluxo de turistas, perdendo apenas, nesse índice, para a França. Possui cerca de 39,9 milhões de habitantes sendo 98,5\% de espanhóis, que utilizam como idioma o espanhol e algumas línguas regionais tais como basco, galego e catalão. A religião dominante é o cristianismo e a forma de governo é a monarquia parlamentarista. A Espanha é segmentada socialmente, sendo sua sociedade bastante conservadora.
\end{abstract}

Na época de lançamento dessa edição, a economia da Espanha recuperavase de vários golpes, mas o desemprego crescia, enfraquecendo o governo, passando a ter uma onda de assassinatos cometidos por separatistas bascos.

Nessa edição, não há referência ao ilustrador, somente sobre o autor da capa (Daniel Gil), mas deste não foram encontradas informações quanto a sua vida e obra.

A relação que a ilustração dessa capa parece ter com o texto amadiano é a representação do sapato azul com o qual Nacib presenteia Gabriela, para que ela, como senhora casada, possa freqüentar os ambientes sociais. Trata-se de uma alegoria do status social da personagem. Amado (1966, p.298) assim descreve:

Gabriela, de azul celeste, de olhos baixos, sapatos a apertá-la, tímido riso nos lábios, era uma sedução. Entra na sala pelo braço de Tonico, o tabelião numa elegância de 
grandes dias. A casa da Ladeira de São Sebastião estava repleta. Viera todo mundo, convidados ou não, ninguém queria perder o espetáculo.

Na ilustração, vê-se o par de sapatos com formas dentro deles. Essas formas eram usadas, normalmente pelo sapateiro, para moldar e alargar os sapatos, para que ficassem adequados aos pés que iriam calçá-los. A imagem do par de sapatos pode ter sido escolhida para sinalizar a passagem da classe popular para a burguesia, demonstrando que deveria moldar-se à nova vida. Além disso, há, no romance, referência a um personagem sapateiro espanhol que gostava quando a Gabriela usava a flor vermelha no cabelo, como diz Amado (1966, p. 199):

Fora o sapateiro Felipe - boca suja de anarquista a praguejar contra os padres, tão educado como um nobre espanhol ao falar com uma dama - quem lhe ensinara aquela moda. 'A mais formosa das modas', dissera-lhe: - Todas as muchachas em Sevilha usam uma flor roja nos cabelos.

Além do mais, os tons rosa e azul sugerem a dicotomia homem/mulher, a presença do mundo masculino (azul dos sapatos), no mundo feminino (rosa do fundo da imagem).

O sapato representa, segundo Chevalier e Gheerbrant (200I), um contrato de troca, pois o gesto de usar o sapato representa tomar posse de alguma coisa ou de alguém, ou seja, é um símbolo do direito de propriedade. No texto amadiano, Nacib dá o sapato para a Gabriela para que ela o use nos eventos sociais que iria com ele, o que demonstraria uma mudança de classe, quando deixa de andar descalça e passa a ter sapatos semelhantes aos de uma senhora da sociedade ilheense. $\bigcirc$ uso do sapato pela personagem demonstra ao mesmo tempo, na trama do romance, o direito de propriedade do marido Nacib sobre ela. Vejamos algumas citações de Amado:

Quando dona Arminda por fim desejou boa noite e saiu, a casa vazia e revolta, garrafas e pratos esparramados, Nacib falou:

- Bié...

- Seu Nacib...

- Por que "seu" Nacib? Sou seu marido, não seu patrão...

Ela sorriu, arrancou os sapatos, começou a arrumar, os pés descalços. Ele tomou-lhe da mão, repreendeu:

- Não pode mais não, Bié...

- O quê? 
- Andar sem sapatos. Agora você é uma senhora.

Assustou-se:

- Posso não? Andar descalça, de pé no chão?

- Pode não.

- E por quê?

- Você é uma senhora, de posses. De representação.

- Sou não, seu Nacib. Sou só Gabriela...

- Vou te educar tomou-a nos braços, levou-a para a cama. (AMADO, 1966, p.300-301).

E ela metida em casa, saindo apenas para o cinema com dona Arminda, ou com ele aos domingos, como se nada houvesse mudado em sua vida, fosse ainda aquela Gabriela sem sobrenome que ele encontrara no "mercado dos escravos", não fosse a senhora Gabriela Saad. Para convencê-la de não ir levar-lhe a marmita ao bar, fora uma luta, ela até chorara. Para calçar sapatos era um inferno. Para não falar alto no cinema, não mostrar intimidade com as empregadas, não rir debochada, como antes, para cada freguês no bar encontrado por acaso. Para não usar, quando saíam a passear, rosa atrás da orelha! Deixar conferência por um circo mais mambembe [...] (Amado, 1966, p.320).

Talvez o sapato esteja representado dessa forma, porque deveria ficar no formato do pé da Gabriela, que iria calçá-lo. Como essa forma costuma ser utilizada pelos sapateiros para folgar os sapatos para os pés de quem quer usá-los, quando estes estão incomodando, o ilustrador reforça com a fotografia o sentido observado no texto amadiano e demonstrado com outra linguagem.

Por outro lado, ainda segundo Chevalier e Gheerbrant (200I), o sapato também representa compreensão recíproca, a prova da fidelidade de quem calça. Este sentido remete ao texto de Amado quando Nacib dá o sapato à esposa Gabriela com essa pretensão, mas sem imaginar o sacrifício que seria a sua utilização.

O sapato pode, também, ser a prova da identidade de uma pessoa, pelo tamanho, adaptação e escolha do tipo, tal como demonstra a narrativa da estória infantil Cinderela, e, como acontece na região da Catalunha, pode ser o símbolo da adaptação entre duas pessoas diferentes, a harmonia do casal e a angústia que pode haver entre essas pessoas, caso não haja a adaptação desejada, segundo Chevalier e Gheerbrant (200I). Portanto o sapato, como símbolo e ilustração da capa, não distorce o enfoque literário, apenas enfatiza um traço que pode estar representando, também, a difícil harmonia entre Nacib e Gabriela, e não somente o esforço para a adaptação dela ao grupo social a que Nacib pertencia. 
Não foi percebida nenhuma divergência com relação ao produto obra literária, nessa capa, além da falta da vírgula entre os epítetos e a palavra Gabriela no título do romance.

As capas das edições estrangeiras observadas parecem ter sido publicadas como edições populares ou de bolso. A maioria, assim como as capas brasileiras, não indica a autoria dos capistas, e alguns ilustradores também não são mencionados.

Além disso, em grande parte, as ilustrações escolhidas pelos capistas ou pelas editoras são de artistas conceituados internacionalmente, talvez para demonstrar uma preocupação com a legitimação de Amado em cada país em que foi editado o livro. Por outro lado, percebe-se que alguns capistas conseguiram aproximar a ilustração escolhida para o romance com o sentido da narrativa literária que embala, mas em outras capas parece que o capista demonstra o romance com reflexos de um sentido absorvido anteriormente, ou seja, por algum conhecimento preexistente, ligado ao seu imaginário.

Percebe-se, ainda, uma tendência de enfocar o romance com representações que se relacionam com a presença da natureza da mulher (sexual ou sensual), sedutora, do paraíso carnavalesco, musical e exótico, relacionado ao estranhamento de quem desconhece o local, o autor e a região de onde procede a narrativa.

Sabendo da importância das ilustrações como demonstração de sugestão que o título propõe, questionam-se as conseqüências das traduções e das ilustrações que podem ocasionar distorções de apreensão da Bahia-Brasil, concorrendo para determinadas divergências. Um dos objetivos da literatura é fazer ver, analisar, dar a luz do conhecimento ao leitor, e Amado, no seu texto, mostrou com propriedade uma região de um país considerado "terceiro mundo", sobre o qual poucas obras literárias tiveram tanta divulgação internacional. Pensando na repercussão e nos reflexos que a "cor" da cultura de cada país estrangeiro deixou impregnada na imagem da Bahia-Brasil que Amado "pintou" em sua narrativa, decidiu-se refletir sobre os movimentos dessa terceira "cor" e os efeitos culturais provocados pela propagação dessa "luz colorida". 


\title{
a Propagação da Luz e os Efeitos Culturais
}

\author{
"Uma cultura nacional é um \\ discurso - um modo de construir \\ sentidos - que influencia e organiza \\ tanto nossas ações quanto a concepção \\ que temos de nós mesmos. " \\ Stuart Hall
}




\begin{abstract}
A
luz é definida como resultado de vibrações de um campo magnético perpendicular à direção de propagação em que sua energia apresenta uma distribuição contínua no espaço. Aceita-se a luz como dotada, ao mesmo tempo, de propriedades ondulatórias e corpusculares, o que implica a aceitação de determinado índice de materialidade da luz. Sabendo que a luz se propaga, podemos dizer que o fenômeno de coloração percebido sobre os corpos é o resultado da relação das partículas eletricamente carregadas ante a ação da onda de luz incidente. Com base nisso, observa-se que objetos e corpos não têm cor, o que eles têm é a capacidade de absorver, refratar ou refletir determinados raios luminosos que sobre eles incidem. As cores percebidas nos objetos variam de acordo com a luz que os ilumina.

Ao se fazer a leitura de quarenta e oito capas do livro Gabriela, Cravo Canela, procurou-se relacionar a ação da luz com os efeitos culturais que estas capas estrangeiras refletem. A interferência das ilustrações em cada pode fazer ver/ler a mulher brasileira, representada pela personagem Gabriela, de acordo com a "Iuz" da cultura que a ilumina.

Diante dessa premissa, as descrições de Amado passam a ser partículas carregadas de sentido que, de acordo com a "luz" da cultura incidente, ou seja, a cultura em que será publicada cada edição, emitirá "cores" diferentes. O passo seguinte foi, então, a analisar o que essas "cores", reflexos ou efeitos podem provocar na cultura baiana e brasileira em conseqüência desses diferentes "matizes" impressos nas capas.

O romance objeto de análise, ao ser lançado no Brasil, obteve um sucesso fora do comum. Por cerca de um ano e meio, foram publicadas doze edições, levando o escritor a ser condecorado com vários prêmios. Essa produção foi considerada, por alguns críticos e pela mídia, o livro brasileiro mais popular, provocando discussões calorosas, de forma que poucos intelectuais brasileiros conseguiram ficar indiferentes ao texto.
\end{abstract}


Há uma diversificada recepção crítica no Brasil desde 1958 até o momento atual, como também em vários países onde esse romance foi publicado; ora os julgamentos admitem a qualidade da obra, ora revela-se a popularidade alcançada pela personagem Gabriela, ora é realçado o sentimento da crítica histórico-política da narrativa, ora os acontecimentos e fenômenos do dia-a-dia do baiano são, também, realçados. Segundo Yuri Dashkévitch (Rússia, |96|):

No Festival do Escritor Brasileiro, realizado no Rio de Janeiro, em Julho de 1960, isto é, dois anos após a publicação do romance, "Gabriela" - segundo informe do jornal "O Globo" - ocupou o 1 l lugar como o livro mais popular. Na literatura brasileira dos últimos anos, é bem possível que não haja outra obra que possa competir, em popularidade, com "Gabriela".

Ao mesmo tempo, há muito tempo que na imprensa brasileira não havia lugar para disputas (discussões) tão calorosas em torno de uma obra literária. Tanto os leitores, como os críticos profissionais se manifestaram quanto a essas discussões - tudo indica que poucos conseguiram ficar indiferentes a essa obra.

Foi também muito discutida pelos críticos literários, a criação da personagem mulata, de alma popular, de sedução natural, operando o autor com valores da "brasilidade negra", sem idéia de pecado no amor sexual, ambiguamente inocente e alegre, transgressora de regras em sua situação social. Segundo David Brookshaw (1983, p.|37-|38):

Além de simbolizar o amor livre, Gabriela representa a alma popular em geral. Sua vitalidade e sua sensualidade inconsciente são fundamentalmente inocentes. Amado, em mais de uma ocasião, alude ao "espírito infantil" de Gabriela e, também, do povo. Ele refere-se a ela como "talvez uma criança ou o povo". Afora isso ela personifica, nas palavras de uma personagem, essa força que faz as revoluções, que promove descobertas.

Segundo outros, ao criar essa personagem híbrida, Amado reforça, no seu texto, o mito da mulata como símbolo sensual, pronta para receber o patrão, árabe, em sua cama. Esse mito tem sua origem no período colonial, durante a escravidão, numa tradição de relações sexuais causais e na instabilidade da vida familiar do proletariado brasileiro. Brookshaw (1983) comenta que o hibridismo, enfocado por Amado, com relação a Gabriela pressupõe que a cultura européia portuguesa e a cultura das várias etnias africanas participam atritando-se para construir a identidade do mestiço brasileiro. Ou seja, na mistura do europeu e do 
negro, presente na história da formação do povo brasileiro, Amado pressupõe a consequente presença do mulato como o genuíno filho do Brasil, pois exalta e demonstra os valores culturais do Brasil mestiço.

Diante desse grande comprometimento de Amado com seu país de origem e com a emergência da antropologia, o autor passou a ser considerado, por alguns críticos, como um dos escritores que analisa a cultura brasileira como uma cultura híbrida. Evidentemente, a própria crítica não deixou, também, de observar que Amado, ao falar do negro, do mestiço, como homem que conviveu com uma cultura repleta de "máscaras brancas"(FANNON, 1983), devido às conseqüências históricas da colonização, dificilmente deixaria de não apenas internalizar alguns estereótipos criados pela tradição branca a respeito dos negros como transparecer esses estereótipos em suas narrativas, mesmo numa abordagem que demonstra aspirações pessoais mais honestas. Fonseca (2000, p. I05) afirma:

Enaltecida como símbolo da mulher genuinamente brasileira, a mulata Gabriela expõe, com sua ingenuidade dengosa, a precariedade da moral que a condena, mas ocupa um espaço que se define pela oposição aos ocupados pelas representações de esposa virtuosa e de mulher honrada, ratificadas pela sociedade. $O$ excesso de atributos físicos que tornam a personagem intensamente desejável acaba por fortalecer o estereótipo de mulata sensual, exuberante, embora o narrador se prime por investi-la de qualidades que convivem, harmoniosamente, com a beleza de seus traços agrestes e o cheiro de "cravo e canela", que condimenta a atração irresistível que a personagem exerce sobre os homens.

A construção da mulata Gabriela como uma das personagens centrais do romance constrói uma tipologia que se torna um exemplo da mistura de etnias e culturas, que, juntamente com a grande divulgação que o romance teve internacionalmente e a grande repercussão editorial obtida, ajudou, então, a transformar a representação da Gabriela em um (ambíguo) tipo da mulher mestiça baiana, nordestina e, metonimicamente, brasileira. A Gabriela vem do sertão, migra para a região da seca, empurrada para llhéus (sua parada), à procura de trabalho, e depois assume o lugar de baiana e brasileira.

Pensando nessa repercussão do romance, considera-se a contribuição da literatura e, principalmente, do objeto livro para a divulgação ou reiteração desse estereótipo, e reflete-se sobre o conjunto formado pelo miolo - obra literária pintada por Amado - e a capa - "luz" gerada pelo ilustrador -, além dos reflexos que esse conjunto pode provocar no observador-leitor. 
Sabendo da abrangência e do valor de um texto literário e da contribuição para o conhecimento mundial, supõe-se que, sendo esse romance uma produção intelectual oriunda do "terceiro mundo", as representações divulgadas passaram a ter legitimidade e destaque num mercado de signos e transações culturais, dominado, em sua maioria, por um "primeiro mundo" que mantinha a primazia de ter construído uma estrutura mental seguida pelas colônias, além do domínio da tecnologia de representação e reprodução. A entrada de produções culturais diferenciadas, como esse romance, no mercado internacional, além de mostrar o estranho (o exótico, para eles), pelo desconhecimento e distanciamento geográfico e pela consequente escassez de informações sobre o Brasil, construiu um imaginário com imagens redutoras e/ou deslocadas. Para poder despertar o interesse do observador-leitor, muitas edições foram ilustradas de forma a reiterar a alteridade e o exotismo na percepção do outro. Em outras palavras, muitas dessas narrativas sobre o Brasil, região pouco conhecida em outros países, podem ter sido feitas em correlação com o imaginário disseminado de um modelo de muIher híbrida e exótica (a personagem Gabriela), como padrão da mulher brasileira, por não ser familiar nesses países a mistura racial. Quando o capista ilustra o texto amadiano com imagens heterogêneas ao sentido da narrativa, a identidade da obra e da cultura baiana e, metonimicamente, brasileira poderá ficar ameaçada, pois a ilustração divergente pode passar a ser uma fonte de conflito para o entendimento e reconhecimento do observador-leitor. Então, o discurso amadiano parece ter sempre uma nova versão dos modelos descritos, a depender de cada diferente leitor ou capista.

Encontram-se algumas representações que parecem demonstrar o romance por simulacros, já que as imagens impressas se assemelham a compensações formais utilizadas por falta de conhecimento do que está sendo narrado no romance. Também se considera que essas representações podem ter surgido devido a algum conhecimento prévio do capista sobre a cultura baiana ou brasileira.

O uso desses simulacros pode levar o público estrangeiro a fazer conceituações idealizadas, mas distorcidas, sobre a Bahia/Brasil, a criar outras encenações imaginárias, dificultando a possibilidade de encontro com o discurso de origem, ou seja, com a cor primeira que Amado deu ao seu discurso, baseado na observação de uma cor local e dos pigmentos da terra baiana e brasileira. $O$ uso de um simulacro pode levar o observador da capa a pensar o impossível, já que o pseudo-referente no texto literário foi substituído por um referente exótico 
e inesperado ou caricatural. Essas ilustrações baseadas em conceitos diferentes do texto literário que a capa embala, levam o leitor a uma distorção de conhecimento da cultura baiana e a uma identificação de um tipo étnico de mulher com as novas características dadas por quem ilustrou.

Inicialmente, como uma das consequências que divulgações distorcidas como essas podem vir a provocar para a cultura baiana, todo o trabalho do produto livro pode passar a ser uma operação desconstrutora, pela introdução das novas formas de ver que deixam transparecer a ressonância ou os reflexos dos grupos que as construíram. O livro passa a demonstrar um movimento através do qual se desloca o sentido tradicional proposto por Amado para uma nova temporalidade, deixando apenas fragmentos que restaram diante da multiplicidade de forças presentes em cada construção desse produto. Nas várias e posteriores edições, não encontramos mais o retorno fiel à obra amadiana do período do lançamento, pois o que retorna não é idêntico, mas um plural consequente das vontades que selecionam o que deve ser reafirmado ou modificado, incentivando, sempre, uma estrutura de alteridade.

A Gabriela passa a ser um instrumento de manipulação de editores e capistas que, em cada ilustração, apresentam uma paródia diferente, fazendo com que o perfil da personagem traçada por Amado torne-se, muitas vezes, irreconhecível, sobretudo porque não é mais apenas um.

É evidente que essa criação literária amadiana dá uma identidade a determinado tipo de mulher baiana, mas esse olhar passa a ter uma série de novas representações, como numa teia de crescimento incontrolável. Essa pluralidade de modelos da Gabriela-mulher baiana dá lugar a determinadas arbitrariedades sem regras e desencadeia uma violência sutil e requintada, muitas vezes por uma censura velada, instituída por uma força performativa das instituições editoriais.

Pode-se considerar, também, que essa pluralidade de tipos representando a Gabriela pode estar enriquecendo-a mediante a possibilidade de uma modificação infinita, apresentada por um procedimento metafórico, sem possibilidade de recuperação do modelo inicial, mas sempre o atualizando, ou seja, tornando essa personagem constantemente inserida num novo contexto. Essa infinidade de modelos cria uma equivalência que pode vir de encontro, não somente, à descrição do povo baiano-brasileiro criado por Amado, mas a uma estória construída como identidade que, ao ser constantemente modificada, torna-se aberta. Os novos modelos estão sempre desmontando a Gabriela descrita por Amado e transportando-a para outro lugar. 
Observa-se, ainda, que a primeira capa estrangeira que ilustrou o romance é que introduz o destaque da Gabriela na capa, enfoque este, que foi adotado, posteriormente, por sete capas brasileiras e vinte e sete capas estrangeiras. Quem inicia esse enfoque são os editores franceses com a primeira edição estrangeira desse romance, um ano depois do lançamento no Brasil. Registra-se o poder intelectual da França como país ocidental da Europa, considerado de "primeiro mundo", com grande autoridade intelectual na relação entre Ocidente e nãoOcidente, e que pode ter ajudado a definir a cultura de vários países não-ocidentais por meio da divulgação de livros e escritos organizados sob o olhar dessas autoridades intelectuais ocidentais. Essa coincidente liderança nos fez registrar e refletir sobre um poder ocidental nas produções culturais que pode, ainda, estar "vivo" e atuante. Said (1990, p. I5), ao demonstrar o discurso do Ocidente sobre o Oriente, denomina (um poder dos países imperialistas da Europa sob os países não ocidentais) de orientalismo, analisando-o dessa forma:

O orientalismo pode ser discutido e analisado como a instituição organizada para negociar o Oriente-negociar com ele fazendo declarações a seu respeito, autorizando opiniões sobre ele, descrevendo-o; colonizando-o, governando-o: em resumo, o orientalismo como um estilo ocidental para dominar, reestruturar e ter autoridade sobre o Oriente.

Além do mais, o orientalismo tinha uma posição de tal autoridade que eu acredito que ninguém que escrevesse, pensasse ou atuasse sobre o Oriente podia fazê-lo sem levar em conta as limitações ao pensamento e à ação imposta pelo orientalismo.

Teorias, romances, descrições sociais e relatos políticos a respeito do nãoOcidente, ou seja, dos países não-eurocêntricos, relatam seus povos, costumes e destinos como diferentes da cultura ocidental, devido ao olhar do Ocidente. É como se a ilustração escolhida pela editora francesa, apesar de ser de um artista brasileiro, fosse mais coerente, ou adequada, com a narrativa de Amado do que a ilustração feita pelo capista da editora brasileira que lançou o romance no mercado. Ao lado dessa ilustração francesa, o título que ancora a imagem (Fille du Brésil), modificado, sugere que a Gabriela é filha do Brasil e apresenta esta personagem como um modelo generalizado de mulher brasileira para outros países, por meio de um discurso que está posicionado num lugar de autoridade intelectual eurocêntrica. grande número de repetições do mesmo enfoque pode estar demonstrando o valor dado a esse discurso e, ao mesmo tempo, faz valer o prestígio de quem o emite, perpetuando e legitimando o olhar francês sobre a Bahia-Brasil. 
Posições como essas, que servem de exemplo, podem ainda fazer supor que a cultura brasileira estaria sendo representada por discursos semelhantes, provenientes de olhares de outros não-brasileiros reafirmando, pelo distanciamento, os modelos baseados em generalizações históricas com vocabulários e imagens domesticadas para o uso de outras culturas. Tais representações podem estar funcionando como um processo de simplificação política e estética, fazendo o observador ignorar as peculiaridades de identificação necessárias ao reconhecimento, repetindo e reforçando estereótipos e modelos que mantêm a oposição entre essência e aparência.

A Gabriela - mulher idealizada por Amado -, como fruto de uma voz masculina, expressa fantasias de um imaginário masculino que a torna objeto de desejo, e ao passar a ser filha do Brasil, consequentemente o novo modelo da mulher brasileira pode ter omitido características da personagem amadiana, tais como inocência, alegria, pecado, sedução, permissividade, enfim, uma mulher sexualmente livre de regras e normas sociais. A libertação sexual que Amado relata em seu texto, parece que foi escolhida e demonstrada por 17 capistas com representações de modelos nuas e seminuas. Seguindo essa premissa, pode-se até deduzir que a nudez que essas capas demonstram, deve estar reforçando o estereótipo do mestiço e do negro, sempre fixado no genital, identificando a ilustração com outras raças primitivas, instintivas e sexuais em contrapartida à inferioridade intelectual. Não se pretende avaliar, neste trabalho, a contribuição do texto de Amado para esse estereótipo, mas também não se pode deixar de observar a tendência para a escolha desse enfoque e a consequente contribuição dessas ilustrações.

A presença da mulata nua nas capas desse romance reforça o estereótipo da mulata poderosa sexualmente, a partir do momento em que mantém esse ponto seguro de identificação, provocando a interpretação do observador-leitor através de um ponto que pode já estar assegurado na identificação da mulata, do negro e do híbrido no país em que será lida aquela edição. Considera-se, então, que a utilização desse estereótipo pode estar impedindo a variação interpretativa do objeto de análise, provocando no observador-leitor uma interpretação cristalizada, reconhecível como se fosse simplesmente realidade.

Essa forma de ilustrar, reafirmando generalizações que provêm de contribuições históricas, pode afetar o modo de ver as mulheres não-brancas, assemelhando-se a efeitos de um preconceito (conceito prévio) estabelecido como verdade. Esse olhar dos publicitários brasileiros e estrangeiros, pelo que transparece nas 
capas, pode ser reflexo, também, da herança colonial, do patriarcado, do racismo e da cultura, que atribuem às mulheres papéis sociais, principalmente como objeto de prazer do homem. Segundo Sant'Anna (1993), esses papéis se diversificam de acordo com a cor da pele a ponto de, com o passar dos tempos, a mulher negra se tornar cada vez mais sensualizada e animalizada, diferindo da mulher branca, elevada a mulher-flor, numa analogia à flor que enfeita os jardins ou os bailes de valsa, a mulher pura, intocável e mãe, enquanto a mulher negra ou híbrida é a mulher-fruto, que sacia os desejos, a mulher da cozinha, dos pomares, onde ficam as frutas comestíveis, fazendo analogia a uma fome gastronômica e sexual.

Esses papéis determinados pela colonização, ao serem reafirmados nas ilustrações, fazem sempre lembrar uma agressividade canibalesca pela mulher de cor negra, passando do visível ao comível, e esse romance amadiano assim como as suas capas não parecem escapar desse exercício de poder de um sistema falocrático. A mulata está, sempre, num lugar recorrente do desejo imaginário escravocrata. Segundo Fannon (1993, p.139) "[...]o negro no imaginário das sociedades colonizadas, geralmente está associado ao animal, imagem que se modela a partir das idéias de selvageria, fortaleza e sexualidade exarcebada" e, consequentemente, afastando-o do intelectual.

Mesmo sendo a Bahia-Brasil, um local onde existe uma grande concentração de pessoas negras e não-brancas, observa-se que grande parte das capas brasileiras está reafirmando este estereótipo, sem preocupação com um possível reconhecimento do povo ilheense-baiano-brasileiro descrito por Amado.

Essa forma generalizada de ver a sociedade brasileira com homogeneidade racial, que é proveniente de discursos coloniais que criaram uma estrutura disciplinar e segmentada para que alguns países assim sejam vistos, deixa perceber que existe uma relação do tipo racial da mulata com um ser socialmente inferiorizado, colocando essas mulheres não-brancas, segundo Sant'Anna (1993) entre a mulher branca - a santa e a negra - prostituta. Sant'Anna ainda demonstra que a literatura durante séculos intensificou esse aspecto discursivo, especialmente o movimento literário romântico, por isso vários textos literários têm descrito dessa forma contrastante as mulheres brancas- - para serem vistas à distância pelo seu perfume de flor - e a mulher negra, que exige proximidade, tato, paladar e deglutição.

A mulata, personagem amadiana que passou a representar a mulher baianabrasileira, tem parte dessas características na sua descrição e, devido à intensidade de divulgações com esse enfoque, percebe-se que os capistas brasileiros e estrangeiros 
destacaram-na em seus trabalhos, mantendo o mito da sexualidade da mulata. É como se esse discurso fosse competente, já estivesse legitimado como verdadeiro e instituído, demarcando a posição e a relação da mulata na sociedade baiana e transformando-a, por sua cor, em elemento negativo. $\bigcirc$ excesso de atributos físicos descritos por Amado, ao demonstrar essa personagem, deve também ter contribuído para o surgimento de representações que fortalecem esse estereótipo da mulata sensual.

A preferência pela representação da personagem sempre nua pode demonstrar uma resistência negativa desses capistas quanto à visão dos negros e mulatos, mesmo admitindo que podem ter sido feitas essas escolhas tendo em vista a facilidade de decodificação do público, o que também validaria esta premissa.

Quando pistas ressaltam atributos do corpo negro ou mestiço como produto altamente desejável repercutem associações com os discursos colonialistas, despersonalização que pode contribuir negativamente, também, para a dignidade cultural do Brasil. A sedução, que está aliada à representação da personagem mulata na maioria das capas, ao passar a ser estreitamente relacionada à mulher brasileira, pode trazer, para os brasileiros algumas repercussões negativas. Seduzir, etimologicamente, quer dizer desviar, tirar do caminho, por isso pode ficar subtendido para os observadores que a mulher brasileira é sensual e disponível sexualmente e que, neste campo, tudo é permitido sem maiores punições para quem o faz, confirmando a falácia de que, abaixo do Equador, "não existe pecado" e por isso tudo é permitido e possível. Tal situação é percebida, atualmente, no setor de turismo da Bahia, dada a conseqüência de divulgações sobre o Estado e o País, nas quais existe um apelo à sedução exacerbada nas imagens das mulheres brasileiras enviadas para países estrangeiros, e que funcionam como um chamariz, principalmente para a Bahia.

A sensualidade da mulata baiana tem sido fartamente explorada pela literatura e pela mídia, assim como pelo mercado da prostituição e pelo tráfego de mulheres, inclusive de adolescentes. Grande parte do contingente de visitantes que chegam à Bahia, com pacotes turísticos comprados em seus países, considera as "aventuras eróticas" como parte do negócio. Pode não ser por acaso que, nos últimos tempos, a Bahia faz parte da lista de locais de maior procura no mundo para o turismo sexual, aliando-se a uma rota que impulsiona o turismo graças ao sexo. Vale salientar que a grande maioria das mulheres que participam dessas aventuras é de negras e mulatas de baixa renda, que acorrem para tal situação na esperança de mudarem de vida. 
Depoimentos narrados no trabalho "A Bahia veiculada para o turismo", 2001 executado por Sônia Caldas junto com alunos da FACTUR e publicado em (Turismo, Tendências e Debates, Ago,2005)
Esse tipo de turismo está baseado numa relação de poder desigual, entre países, classes, sexos, raças e etnias, sustentada por uma história colonialista de sexo e racismo. $O$ estereótipo da mulher mulata como mulher-fruto, liberada sexualmente, vem repercutindo uma disponibilidade para qualquer situação e para qualquer aventura sem moral nem pudores, a ponto de esta liberação ser associada à cultura baiana, originando afirmações de que o culto ao corpo, junto aos hábitos ociosos de vida, a culinária picante, o ritmo contagiante da música baiana, o carnaval e as festas populares conduzem ao sexo. Na revista do jornal El Mondo, n.89, de grande circulação na Espanha, encontramos a seguinte citação: "Ser mujer en Bahía es, para todos los efectos, poco menos que ser prostituta”. A consequência de divulgações que incentivam este enfoque vem atingindo pessoas, principalmente do sexo feminino, profissionais baianas, especialmente as que trabalham na área do turismo. É comum ouvir histórias dessas profissionais que foram assediadas quando exerciam suas atividades profissionais' em companhias aéreas, hotéis e outros ambientes freqüentados por turistas. Este assédio parece estar deixando essas profissionais em situações difíceis e constrangedoras.

Parecem ser consequência também da literatura, as peças publicitárias brasileiras que colocam em primeiro plano a nudez da mulher baiana, em detrimento do patrimônio natural e cultural da Bahia. Esta nudez pode passar a ser considerada como o produto principal que a Bahia quer vender, já que a encontramos exposta, em primeiro plano, na maioria dos folders, catálogos, anúncios de revistas e embalagens que encontramos veiculados no mercado divulgando a Bahia para o turismo. Torna-se importante salientar que tal postura pode estar incentivando, inclusive, o turismo sexual infantil, com o assédio de menores, numa posição contrária ao trabaIho desenvolvido pelos Órgãos Federais no Brasil que divulgam estar o Brasil de olho nesse tipo de turismo, pedindo inclusive que o denunciem.

Dessa forma, considera-se que, se alguns capistas estrangeiros escolheram demonstrar a mulata brasileira baseada nesse estereótipo, a causa provável desta forma de ver está presente em seu imaginário ou na sua cultura e por isso eles podem, facilmente, ter captado tal enfoque no texto literário, escolhendo-o para ilustrar o livro, ou, ainda, poderiam ter escolhido para assegurar privilégios de superioridade e poder que eles acreditam que possam ser gozados por poucos. Mas, o que se torna curioso é que a maioria dos capistas brasileiros reforçam este estereótipo em suas representações, sem pensar nas conseqüências negativas para a mulher mestiça brasileira. 
O grau de nudez da personagem representada na capa de lançamento do romance no Brasil é mínimo, diante da exposição das partes sexuais da mulher impressas na capa mais recente, ano de 2000, fazendo supor que nesse romance, apesar dos múltiplos e sérios enfoques relatados por Amado, principalmente o político, o ponto que parece mais forte e mais vendável é o sexo, por isso mais evidenciado na maioria das embalagens-capas, sem consideração de que este apelo erótico pode, também, estar incentivando uma violação.

Esse enfoque da mulher-fruto para representar a mulher brasileira, pode ter, também, incentivado as letras de uma série de músicas que hoje são veiculadas na mídia, assim como a exposição exacerbada do corpo feminino nos meios impressos e televisivos pode ter sido reforçada por produtos literários como os livros ou pela divulgação de novelas como Gabriela, Cravo e Canela, nos quais as capas e cenas atraem pela sexualidade da modelo impressa, deixando subentendido que a mulher baiana-brasileira ilustrada é uma mulher fácil, permissiva e, portanto, visualizada como fácil de ser degustada. $\bigcirc$ que faz ver, também, que tal tipo de mulher, ao ser voltado para os instintos sexuais, pouco se preocupa com assuntos de ordem intelectual, tornando-a por isso menor e inferior diante das mulheres ocidentais ou mesmo diferentes das mulheres, aparentemente, brancas.

A personagem Gabriela foi-se modificando a partir do olhar de cada ilustrador. As modelos possuem as características do público-alvo a que se destina aquela publicação, logo a possibilidade de uma transparência, para que haja uma fidelidade ao texto de origem, deixa de existir nas ilustrações das capas. As capas, como embalagem do produto livro, variam de acordo com a formação e as condições sociais de cada ilustrador, e algumas demonstram terem sido interpretadas e reelaboradas de forma totalmente alheia ao texto amadiano e à cultura deste escritor, passando a ser uma adaptação, uma reinterpretação, ou seja, muitas delas passam a exprimir o tecido simbólico da vida cotidiana do país para o qual se dirige aquela edição. As várias edições brasileiras demonstram uma constante atualização da recepção, do que acontece em cada contexto, a ponto de cada embalagem-capa ser remodelada a partir de conceitos locais e globais, produzindo relações entre o desenvolvimento cultural desses sistemas e a narrativa literária de Amado, ao tempo em que contribui para aumentar a legibilidade dessas capas diante dos novos públicos.

Como identidade é, também, representação e ação e se torna grande a responsabilidade da literatura na representação da diversidade das culturas, deve-se 
estar atento ao menor espaço concedido aos países latino-americanos e à importância da variedade de traduções e de edições que esse romance amadiano possui. Gabriela, Cravo e Canela não é portador apenas de uma representação ou significação intrínseca, a que quis imprimir Amado, mas também daquelas que foram formuladas pelos observadores, tradutores, ilustradores, capistas, diretores de novelas, filmes e leitores de locais, épocas e ideologias diversos que o reproduziram.

Identidade é, ainda, compartilhar, com um grupo, determinados elementos, é se tornar idêntico, e os que não compartilham desse universo não têm os mesmos símbolos, os mesmos objetos, os mesmos rituais, os mesmos costumes. Possuem, portanto, outro cenário, são diferentes. As ilustrações que usaram uma representação que oculta a heterogeneidade da região descrita por Amado, reorganizaram o sentido do texto literário em função do sistema conceitual do país em que a edição deveria ser lançada, com características de outra cultura, provocando uma fissura entre o texto de origem e a tradução.

Constata-se a conservação de alguns modelos nas diversas capas, principalmente com relação ao modelo da personagem Gabriela lançado pela mídia eletrônica no Brasil, mas também se observa que, em algumas edições estrangeiras, em vez de representar "o diferente" daquela cultura, o capista utiliza como critério para a representação do texto amadiano algo que possa ser digerível pelo público-alvo, que se possa tornar íntimo e reconhecível, encobrindo a complexidade das diferentes formas híbridas. Essas representações podem estar sendo escolhidas conforme os projetos de legitimação, numa tentativa de neutralizar, domesticar, através de um sistema já ritualizado pelas práticas sociais. Parece que as editoras procuram representar as obras literárias perpetuando a ordem estabelecida no contexto em que atua, mantendo os acontecimentos relatados como fundadores, os protagonistas e os rituais, fazendo supor que, se representassem o estrangeiro, poderiam estar desafiando a ordem daquele país ou não seriam entendidos. Tal posicionamento poderia estar provocando um achatamento cultural que não promove o conhecimento, nem a reflexão crítica do observador-leitor ou, em último caso, acarretando a pouca procura e vendagem do produto. A consequência dessa forma de proceder, no caso em análise, poderia ser o desconhecimento da Bahia. A função da literatura, de fazer ver e conhecer, deixa de existir, acostumando o público às narrativas fabricadas a partir de signos inteligíveis para serem assimilados sem esforço. 
Ressalta-se a constante utilização de obras de arte de artistas legitimados pela comunidade artística para a ilustração do livro. Isto poderia reduzir o assombro do público-alvo diante do diferente, do exótico, pela fascinação diante da beleza e da manifestação artística, sugerindo, dessa forma, uma ressignificação do texto literário através das relações rituais com a arte e dando continuidade à versatilidade sempre híbrida das reinterpretações.

$\bigcirc$ trabalho do capista está sempre dentro da esfera de controle do seu país e de sua rede de produção e, consequentemente, este controle parece funcionar sempre como censura, que impede as informações que vão contra o estabelecido pelo poder dominante de cada país. Qualquer nova interpretação do capista somente seria possível a publicação via obra de arte, como se o ilustrador-artista plástico renomado tivesse autoridade para enunciar o diferente.

Acredita-se que essa autoridade dada às artes plásticas deva-se ao fato de que a arte descreve o objeto como se o visse pela primeira vez, como se não existissem fórmulas para o capista descrever e, por isso, ele optou por escolher o trabaIho de um artista plástico, pela legitimação social que o autoriza a criar e divulgar uma percepção particular. $\bigcirc$ risco dessas interferências particulares no modelo da personagem e, consequentemente, na mulher baiana-brasileira, é quando esse novo modelo artístico torna-se canônico pela legitimação de quem assina, perdendo a força como obstáculo e procedendo como inovador que passa a fazer parte da personagem amadiana e das características da mulher baiana. Estes novos modelos criam uma série de entre-lugares que dão início a novos signos que redefinem a Gabriela baiana de Amado.

Existe, em algumas dessas capas, uma lógica de inversão na representação do personagem que dá nome ao romance, e que supomos ser uma negação devido ao estranhamento, pela dificuldade de reconhecimento de outras culturas e a necessidade de representação no momento dos deslocamentos culturais. Esta ação inversa faz pensar no controle e na responsabilidade com as representações das ações humanas e com o mundo social. A repercussão disso é que representações de um povo, mesmo como ficção, podem transformar a forma de ver uma cultura e ainda afetar as bases tradicionais de uma identidade, através de um olhar discriminatório que nega a diferença cultural e racial.

Uma Gabriela representada de pele branca, ancorada por um título modificado que omite e silencia as palavras que reforçam a característica da cor de canela da pele e o cheiro de cravo (condimentos orientais) muito usados no país 
onde se fixou a existência desse personagem, demonstra um reconhecimento da diferença e, simultaneamente, a recusa e a utilização de uma máscara. A partir dessa utilização, a identidade do personagem passa a ser encenada, ou seja, deixa de haver uma representação do discurso de Amado e passa a ter uma encenação, um mascaramento metafórico.

A questão da diferença é não apenas um problema de autoridade e de poder das editoras, que podem estar impondo ao capista o modo de representação interessante para aquele produto mercadológico, como também um problema de poder político e de grupos dominantes que contribuem para as narrativas que ajudam a moldar uma identidade. Talvez não fosse interessante para alguns grupos dominantes de países estrangeiros deixar conhecer uma cultura de um país denominado de "terceiro mundo" ou, ainda, talvez não fosse de interesse mercadológico para esse público uma cultura que, muitas vezes, não têm nenhuma referência. Mas pode haver, além disso, uma necessidade inconsciente de não representar personificações de um povo e culturas híbridos, diferentes, que através da sua mistura possa ameaçar a ilusão de uma população racialmente pura e superior racionalmente/ intelectualmente.

A questão da legitimidade e dos interesses em torno das representações de populações híbridas e da raça negra provoca o questionamento sobre os efeitos das identidades conflituosas e fantásticas, não somente com relação aos personagens, mas também com relação às conseqüências desses efeitos para o povo que ele representa, gerando classificações confusas no momento do reconhecimento. Ao fazer sua leitura, pode ser que, na equivalência linear interpretativa entre vivência e idéia, o observador-leitor passe a dar significados diferentes ao povo de que aquele personagem diz fazer parte.

Mesmo sabendo que a literatura é composta de narrativas ficcionais, com invenções arbitrárias, é através da produção dos sentidos das narrativas e das representações culturais que surge a idéia de nação, pois também conceituamos a nação como uma comunidade simbólica, imaginada.

Quando a personagem baiana é representada branca, introduz-se como possibilidade de interpretação um modelo que a desestabiliza, retirando uma possível unidade representativa, o que significa que ela já não possui características únicas. Supõe-se que, a partir daí, o que Amado chama de mulata Gabriela pode ter as características físicas de várias etnias. Nesse instante, questiona-se como ficarão as características do povo baiano que essa personagem representa no imaginário do 
observador-leitor. A personagem apreendida com características divergentes da cultura de origem, através de uma cena dupla ou tripla, pode provocar um saber cultural que também contribui para o desconhecimento do sujeito que ela representa, e para a cisão da fronteira que estabelece o espaço da nação brasileira híbrida. Poderá estar acontecendo, então, uma perda da identidade da personagem no processo da significação além de uma perda da identificação da cultura do povo baiano que Amado descreve, através da sucessão de personagens plurais, formadas por uma subtração dos traços originais e uma inclusão de novos modelos.

A cor da hibridez negada pode ter o sentido negativo dado à raça negra pela colonização, pela religião católica, como contrária à expansão da luz divina, e pela relação óptica com a cor preta que absorve toda radiação luminosa que sobre ela incide, deixando subentendido que as pessoas de pele negra ou não branca carregam consigo um mundo pecador, desconhecido e marginal. Não se trata de um estranhamento que gera uma existência fronteiriça, mas de uma opacidade que nos faz pensar sobre uma omissão, um silêncio das questões de identificação, que pode levar os observadores-leitores a fantasias racistas de pureza, de perseguição racial e até de rejeição.

A identidade não é um produto acabado, é um processo problemático de acesso a uma imagem de totalidade que se modifica, de acordo com as formas com que essa imagem é interpelada ou representada. Dentro de qualquer personagem, há identidades contraditórias que podem levar a identificações continuamente deslocadas, mas, à medida que esses sistemas de significação e representação cultural se multiplicam, encontra-se uma multiplicidade de identidades possíveis com cada uma das quais poderia ser essa personagem identificada temporariamente.

Nas capas brasileiras, por exemplo, percebemos um processo de atualização contextual que nos faz pensar em um tempo dito por Amado que está sempre em outro lugar, a representação de uma repetição apenas contextualizada, uma ilusão de presença. As transformações resultantes dessas representações contextualizadas vão mudando a identidade dessa personagem, abalando o texto amadiano e, por outro lado, essas novas características projetadas podem, com o tempo, passar a fazer parte dele. Seguindo essa premissa, podemos até prever que a nudez crescente que as capas brasileiras demonstram, pode levar, futuramente, a personagem a ser representada sempre totalmente nua, acarretando conseqüências incalculáveis. 
Essa nudez e suposta disponibilidade da mulher brasileira, que imaginamos fazer parte, também, do olhar dos brasileiros e que consideramos conseqüência de um olhar europeu sobre a América Latina, parece ter sua origem na época da colonização quando os portugueses chegaram ao Brasil e tiveram a impressão de ver a natureza surgir nua com árvores de portes majestosos, terras fertilíssimas, clima de eterna primavera, aves de cores deslumbrantes com cantos nunca ouvidos e homens e mulheres nus. Essas descrições que foram evidenciadas desde a Carta de Caminha, parecem ter sido incorporadas à própria imagem do Brasil e à identidade do continente descoberto como um mito fundador. Segundo Chauí (2000), o mito fundador impõe um vínculo interno com o passado como origem, isto é, com um passado que não cessa nunca, que se conserva, perenemente, presente. Por isso mesmo, não permite trabalhar a diferença temporal e a compreensão do presente enquanto tal, assim como pode ser um impulso a repetição de algo imaginário que cria um bloqueio à percepção da realidade e impede lidar com esta.

Essa primeira visão paradisíaca parece que continua acompanhando as representações do Brasil, pois outra representação constante nas capas é a Gabriela junto a algum elemento da natureza, como se fosse necessário imprimir algum signo que lembre a natureza para sugerir o local onde aconteceu a trama do romance, o que podemos considerar, também, um reforço a uma estereotipada visão de paraíso sobre o Brasil.

A própria Gabriela é relatada no romance como voz de uma natureza paradisíaca, sempre disponível para expansão dos seus impulsos naturais, com força vital para subverter, na trama, o estabelecido na sociedade conservadora illheense.

Essa imagem paradisíaca poderá deixar subentendidos vários outros "paraísos", inclusive, novamente, o permissivo, em que tudo pode ser feito sem restrições. Esse discurso vem dominando a existência dos brasileiros desde a descoberta do País e se estende por toda a sua história, produzindo e absorvendo sentidos e instituindo uma mesma forma de ver o Brasil. As capas, como mensagem publicitária, não deixam de refletir essa visão. O mais problemático para a cultura baianabrasileira, nesse aspecto, é a constatação de que o povo brasileiro também se descreve através de uma herança de sentidos de um olhar estrangeiro, inicialmente contemplativo, mas que se tornou rapidamente predador, fazendo com que os próprios brasileiros percam a oportunidade de inventar seus símbolos originais e permaneçam na sombra da expressão do discurso sobre o paraíso tropical visto pela Europa. 
A ilustração escolhida para a capa da Tcheco-Eslováquia, de 1967, que imprime um personagem tocando uma viola, poderia estar chamando atenção para o interesse do povo brasileiro pela música, através da representação da viola como símbolo da festa e da alegria. Além disso, poderiam estar subentendidos, nessa representação, um ócio instintivo tribal e um prazer aliados a uma construção imaginária de malandragem, proveniente de uma formação social em que o trabaIho não comparece, chegando ao exagero da imagem de que a Bahia é uma festa permanente. Essa forma de ver vem inundando a mídia, ao mesmo tempo em que se vem associando à linguagem de grupos políticos hegemônicos que procuram legitimá-la. É comum, em determinadas áreas de trabalho, como, por exemplo, telemarketing, que profissionais durante o seu trabalho, ao se identificarem como residentes em Salvador, ouçam observações, tais como: Na Bahia, alguém trabalha? Na Bahia, não é sempre carnaval? Observações e comentários como estes reforçam o preconceito de que, devido ao fato de o baiano gostar de festa, de música e de alegria, parece não gostar de trabalhar. Sem considerar, inclusive, que, para haver carnaval e música, se requer muito trabalho.

Sob o mesmo olhar analisou-se a capa de Estocolmo, de 1963, que retrata uma passista de Escola de Samba, o que lembra o carnaval carioca. Esses elementos impressos podem deixar subentendido que o povo baiano/ brasileiro dialoga com a música, com a dança e com a sedução que a dança provoca e, ao mesmo tempo, com as características do evento carnaval como troca de lugar, ou seja, com a inversão de papéis sociais durante o carnaval. Nessas características, pode já estar implícito um carnaval sinônimo de liberdade, permissividade, fantasia, prazer sexual etc., idéias que já fazem parte do olhar do estrangeiro sobre esse evento e que, em momento algum, é citado por Amado no romance. Ao se relacionar Escola de Samba e carnaval à Gabriela e, consequentemente, à mulher brasileira, também podem ser lembrados, pelo observador, gestos, ritmos, vestimentas, músicas, desfiles e dramatizações que acontecem no período carnavalesco em alguns Estados brasileiros. Mas essas lembranças podem levar, ainda, à associação do País e da mulher brasileira às características de um paraíso da bagunça, da loucura, do abuso, da malandragem, dos exageros e da preguiça, que já estão implícitos nas imagens divulgadas sobre o carnaval brasileiro.

Diferentes Gabrielas ilustraram esse romance amadiano, provavelmente criadas pela necessidade de sobrevivência da comunicação, fazendo existir não apenas uma ou algumas mulatas, mas um número correspondente ao de seus ilustradores e de tantas "cores" quantas possam surgir no espectro. A variedade representativa 
ou refração da "luz" emitida por Amado influencia na construção cultural da nacionalidade do povo brasileiro, pois esses "novos" signos podem passar a funcionar em nome do povo (comunidade simbólica) ou da "nação" (como narração) brasileira, tornando-os internalizados. Passam, dessa forma, a serem fontes simbólicas da identidade cultural brasileira, possibilitando um deslizamento e uma mutação contínua no modo como Amado ajudou a descrever llhéus e que passou a representar, como metonímia, a Bahia e a "nação" brasileira.

Sendo cada enunciado um ato social e de comunicação, que tem um significado ideológico, no momento em que os enunciados amadianos fazem um intercâmbio com o que foi impresso pelo capista, a identidade da Gabriela se modifica. Consequentemente, a identidade do povo brasileiro vai, aos poucos, sofrendo alterações. Cada "novo" modelo da Gabriela que se insere em uma realidade cultural, através do veículo livro, passa a ser "consumido" sem a percepção da sua contribuição para a construção do conhecimento do povo brasileiro, lançando uma sombra entre as significações que distinguem o brasileiro do outro estrangeiro. Essas sombras, por outro lado, podem vir a prejudicar a cultura brasileira no cenário internacional e contribuir para a manutenção das manobras ideológicas que levam à marginalização dos países do chamado "terceiro mundo". É o jogo do poder inscrito na linguagem das capas.

A imagem da mulata baiana e brasileira definida por Amado passa, através das capas, a ser provisória e variável, diante das múltiplas e cambiantes "cores" que foram pintadas pelos ilustradores. Esta infinidade de matizes tornou a Gabriela uma baiana que tem todas as cores dos seus descendentes, por isso híbrida e multicor.

Essas múltiplas "cores" e seus vários "matizes" representativos é que vão permitir novas articulações, contribuindo para uma estrutura identitária mais aberta, levando o produto livro e a produção literária a uma posição de discurso e argumento e não de verdade e documento. Contribui para uma concepção mutante do produto livro, distanciando-o da velha confiança e certeza dos mitos de origem de um produto literário.

Consumir um livro é participar de um cenário de disputas que a sociedade produz e, como o seu constante consumo pode tornar mais inteligível um mundo no qual o sólido se evapora, a mercadoria livro colabora para o pensar. Mesmo considerando que o mercado editorial hegemônico exerce a função de "filtro" na seleção de modelos e ofertas para o público, percebe-se a contribuição dada para a reinterpretação dos processos históricos híbridos. 
A mistura dos ingredientes culturais baianos narrados por Amado e olhares estrangeiros e brasileiros impressos nas embalagens, ao interagir com cada público-alvo, pode manter algumas crenças antigas e locais, mas também se constitui de metáforas de uma aliança social, a serem estabelecidas como marcas ou relatos de uma época. Cada vez que acontece uma re-marca, ou seja, uma nova representação, um novo modelo, isto não deixa de ser resultado das forças que disputam a renovação dos pactos editoriais.

Essas marcas que funcionam como pré-texto para o texto amadiano, que é um todo não fechado, transformando-se em um pedaço desconstrutor, abre o olhar do observador para novas interpretações, tornando visível o que, talvez, tenha escapado à sensibilidade do leitor, convidando-o a pensar o "impossível".

A infinidade de capas contribui para desmarcar a originalidade da capa da primeira edição e possibilita a ampliação de novos modelos que impossibilitam o reencontro com alguns fatos da origem do discurso literário ou com um possível discurso essencial. Parece que o salto do velho para o novo está sempre acontecendo com as mudanças das embalagens-capas. Cada nova ilustração sugere ao público uma nova forma de ver, e, por serem arte publicitária, elas fascinam o observador ante a beleza, anulando o assombro do que pode ser considerado diferente. $O$ novo destaque ilustrativo passa, então, a ser aquele que perdeu a relação com o contexto no qual foi criada a capa lançada anteriormente, criando a autonomia e a ilusão de que os novos observadores participam, com os seus valores humanos, da informação que essa linguagem sem palavras emite. Algumas novas Gabrielas não dependem das imagens antigas, rompendo, inclusive, regras preestabelecidas de representação e obstáculos semióticos de significação. Estas novas identidades dadas à mulher baiana através da Gabriela enriquecem a sua subjetividade, expressam a sua universalidade e a generalizam como ser social.

Concluímos, então, que a multiplicidade de modelos também ajuda a desestabilizar os mitos de origem, impede a perpetuação das heranças históricas, desassocia modelos comparativos e fraciona a identidade cultural estabelecida. As divergentes representações da mulata baiana-brasileira contribuem para o conceito de nação híbrida, diferenciando socialmente o tipo baiano-brasileiro de qualquer outro, quando o torna indecifrável e insere uma tendência globalizante que, segundo Hall (2000, p.74), faz parte das "identidades partilhadas" pelo bombardeamento e infiltrações de outras culturas. O mosaico composto das várias representações provoca a reflexão sobre uma mulata de identidade plural, 
menos fixa, mais racional e universalista, uma transição perene, uma multicromia representativa de uma mestiçagem contraditória e conflituosa, na qual as diferenças são agregadas como as múltiplas etnias que formam o povo brasileiro. $\bigcirc$ mosaico formado pelas capas e pelas diferentes etnias que compõem o povo brasileiro, demonstra uma complexidade que serve de modelo para o resto do mundo, reafirmando um convívio agregador e uma experiência harmônica, universal, pacífica e multicor.

Por conseguinte, considera-se que o texto amadiano, ao ser intercambiado sempre com novas embalagens, pode estar perdendo a relação com llhéus-Bahia, mas está ganhando em comunicação, atualização e transformação, ao tempo em que seus capistas e ilustradores passam a ser mediadores e intérpretes das transformações sociais através do uso de metáforas e simulacros que demonstram uma procura democrática para manter viva a "cor local". As metáforas e simulacros inserem o romance na movimentação da história cultural, nos hábitos mais recentes de percepção e compreensão dos setores populares, atraindo sempre novos consumidores. Portanto a união entre miolo-obra literária e embalagem-ilustração-capa, sempre dissonante, celebra a impureza, a mistura, o hibridismo, a atualização e as transformações possíveis, tornando o romance constantemente novo e atual, ao mesmo tempo em que insere, continuamente, essa obra literária, numa postura contemporânea que, por não ser sólida, não se desmanchará no ar. 


\section{Fontes Luminosas}

ALMANAQUE BRASIL. São Paulo: Abril, 2002.

ALMANAQUE MUNDO. São Paulo: Abril, 2002.

ALSTON, P. W. Filosofia da linguagem. Rio de Janeiro: Zahar, 1977.

ALTUSSER. Ideologia e aparelhos ideológicos do Estado. Tradução de J.J. Moura Ramos. Lisboa: Ed. Presença; São Paulo: Martins Fontes, 1974.

ALVES, Ívia. As hierarquias legitimadas: um resgate da crítica de Gabriela, Cravo e Canela e de A morte e a Morte de Quincas Berro D'água. In: CONGRESSO DA ABRALIC, 6., 1999 , Florianópolis. Anais... Florianópolis: Núcleo de Estudos Literários e Culturais/UFSC, 1999.

AMADO, Jorge. Carta a uma leitora sobre o romance e personagem. Salvador: Editora da FCJA, 1970.

AMADO, Jorge. Dona Flor e seus dois maridos. São Paulo: Martins, 1966.

AMADO, Jorge. Gabriela. Berlim: Antkowiak, 1962.

AMADO, Jorge. Gabriela. Berlim: [s.n.], 1964.

AMADO, Jorge. Gabriela. Berlim: [s.n.], 1968.

AMADO, Jorge. Gabriela Clavo e Canela. Argentina: Editorial Losada, 1972.

AMADO, Jorge. Gabriela, Clavo y Canela. Argentina: Editorial Losada, 1990.

AMADO, Jorge. Gabriela, Clavo y Canela. España: Alianza Editorial, 1994.

AMADO, Jorge. Gabriela, Clavo y Canela. España: Muchnin Editores, 1998.

AMADO, Jorge. Gabriela, Clau i Canyella. Cataluña, España: [s.n.], 1997.

AMADO, Jorge. Gabriela: Clove and Cinnnamom. London: Abacus, 1984.

AMADO, Jorge. Gabriela, Clove and Cinnamom. USA: Avon Books, 1988.

AMADO, Jorge. Gabriela, Cravo e Canela. Portugal: Publicações Europa-América, 1960. 
AMADO, Jorge. Gabriela, Cravo e Canela. Portugal: Publicações Europa-América, 1965.

AMADO, Jorge. Gabriela, Cravo e Canela. Portugal: Publicações Europa-América, 1974.

AMADO, Jorge. Gabriela, Cravo e Canela. Portugal: Publicações Europa-América, 1978.

AMADO, Jorge. Gabriela, Cravo e Canela. Portugal: Publicações Europa-América, 1984.

AMADO, Jorge. Gabriela, Cravo e Canela. Rio de Janeiro: Record, 1982.

AMADO, Jorge. Gabriela, Cravo e Canela. Rio de Janeiro: Record, 1995.

AMADO, Jorge. Gabriela, Cravo e Canela. 83. ed. Rio de Janeiro: Record, 2000.

AMADO, Jorge. Gabriela, Cravo e Canela. São Paulo: Círculo do Livro, 1975.

AMADO, Jorge. Gabriela, Cravo e Canela. São Paulo: Martins, 1958.

AMADO, Jorge. Gabriela, Cravo e Canela. São Paulo: Martins, 1966.

AMADO, Jorge. Gabriela, Cravo e Canela. São Paulo: Martins, 1973.

AMADO, Jorge. Gabriela. Dinamarca: [s.n.], 1965.

AMADO, Jorge. Gabriela. Estocolmo, Suécia: [s.n.], 1963.

AMADO, Jorge. Gabriela, fille du Brésil. França: Ed. Seghers- L'inter, 1959.

AMADO, Jorge. Gabriela. Hungria: [s.n.], 1975.

AMADO, Jorge. Gabriela. Noruega: Gyldendal, [19-].

AMADO, Jorge. Gabriela. Polônia: [s.n.], 1968.

AMADO Jorge. Gabriela wie Zimt und Nelken. Berlim: Rororo, 1966.

AMADO, Jorge. Gabrielê. Lituânia: [s.n.], 1994.

AMADO, Jorge. Gabriella garofano e cannella. Itália: Riuniti, 1979.

AMADO, Jorge. [Gabriela, Cravo e Canela]. China: [s.n.], 1985. Caracteres em chinês.

AMADO, Jorge. [Gabriela, Cravo e Canela]. Coréia. [s.n.], 1976. Caracteres em coreano.

AMADO, Jorge. [Gabriela Cravo e Canela]. Grécia: [s.n.], 1983. Caracteres em grego.

AMADO, Jorge. [Gabriela Cravo e Canela]. Irã: [s.n.], 1988. Caracteres em persa.

AMADO, Jorge. [Gabriela Cravo e Canela]. Israel: [s.n.], 1983. Caracteres em hebráico

AMADO, Jorge. [Gabriela Cravo e Canela]. Líbano: [s.n.], 1984. Caracteres em árabe.

AMADO, Jorge. [Gabriela Cravo e Canela]. Líbano: [s.n.], 1990. Caracteres em árabe.

AMADO Jorge. [Gabriela]. Russia: [s.n.], 1961 . Caracteres em russo.

AMADO, Jorge. [Gabriela]. Ucrânia: [s.n.], 1970. Caracteres em ucraniano.

AMADO, Jorge. Mulatka Gabriela. Tchecoslováquia: Odeon, 1967. 
AMADO, Jorge. Mulatka Gabriela. Tchecoslováquia: Odeon, 1974.

AMADO, Jorge. Mulatka Gabriela. Tecoslováquia: Odeon, 1977.

AMADO, Jorge. Mulatka Gabriela. Tchecoslováquia: [s.n.], 1974.

AMADO, Jorge. Navegação de Cabotagem. Rio de Janeiro: Record, 1999.

AMADO, Jorge. O país do carnaval. Rio de Janeiro: Schimidt, 1931.

AMADO, Jorge. Tarçin kokulu kiz. Turquia: Payel Yayineví, 1973.

AMADO, Jorge. Uma coleção excepcional. Lisboa, 1980. Arquivo da Fundação Casa de Jorge Amado, manuscrito.

ANAIS do II Encontro Franco-brasileiro de Análise do Discurso: o discurso da mídia. Rio de Janeiro: Ed. UFRJ, 1996.

ANAIS do III Encontro de Editoração da Bahia. Salvador: Instituto Baiano do Livro, 1993.

ANAIS do VIII Seminário do Centro de Estudos Lingüísticos e Literários do Paraná (CELLIP). Curitiba: CELLIP, 1994.

ANDERSON, Benedict. Imagined comunities. $2^{\text {nd }}$. ed. London: Verso, 1991,

ANDERSON, Benedict. Nação e consciência nacional. Tradução de Lólio de Oliveira. São Paulo: Ática, 1989.

ANTELO, Raul (Org.). Declínio da arte ascensão da cultura. Florianópolis, Santa Catarina: Letras Contemporâneas/UFSC, 1998.

ANTELO, Raul (Org.). Identidade e representação. Florianópolis: Ed. PPGLL: Editora da UFSC, 1994.

ARBEY, José. Guerra fria; terror de Estado, política e cultura. São Paulo: Moderna, 1997.

ARBEX Jr., José; SENISE, Maria Helena Valente. Cinco séculos de Brasil. São Paulo: Moderna, 1998.

ARNHEIM, Rudolf. Arte e Percepção visual, uma psicologia da visão criadora. Tradução de Ivonne Terezinha de Faria. São Paulo: Pioneira, 1992.

AROJO, Rosemary (Org.). O signo desconstruído. Campinas: Pontes, 1992.

ARRIAZA, Manuel. Texto, contexto y situación. Barcelona: Ed. Octaedro, 1994.

ARRIVÉ, Michel. Lingüística e Psicanálise: Freud, Saussure, Hjelmslev, Lacone e outros. Tradução de Mário Laranjeira e Alain Mouzart. São Paulo: EDUSP, 1994.

ARTE no Brasil. São Paulo: Abril Cultural, 1979.

ATAÍDE, Vicente. A narrativa da ficção. 3. ed. São Paulo: McGraw-Hill, 1974.

AUMONT, Jackes. A imagem. Tradução de Estela dos Santos e Cláudio C. Santoro. Campinas: Papirus, 1995. 
AUSTIN, J.L. How to do things with words. Oxford: Univ. Press, I97I.

BAKHTIN, Mikhail. Estética da criação verbal. Tradução de Maria E. Galvão Gomes Pereira. São Paulo: Martins Fontes, 1992.

BAKHTIN, Mikhail. Esthétique de la création verbale. Paris: Galimard, 1984.

BAKHTIN, Mikhail. Marxismo e Filosofia da Linguagem. Tradução de Michel Lahud e Yara F. Vieira. São Paulo: Hucitec, 1995.

BAKHTIN, Mikhail. Questões de literatura e estética: teoria do romance São Paulo: Ed.UNESP: HUCITEC, 1988.

BALTHUS. Disponível em: < http://dossiers. Publico. pt / baltus />. Acesso em: Iº maio 2000.

BANDEIRA, Antônio R. Gabriela: um mito paraíba. A União, local, 3 I maio 1959.

BARROS, Diana Luz Pessoa de. Teoria do discurso: fundamentos semióticos. São Paulo: Atual, 1988.

BARROS, Diana Luz Pessoa de. Teoria semiótica do texto. São Paulo: Ática, 1990.

BARROS, Diana L. P.; FIORIN, José L. (Org.). Dialogismo, polifonia, intertextualidade São Paulo: Edusp, 1994.

BARROS FILHO, Ploiris de. Ética na comunicação: da informação ao receptor. São Paulo: Moderna, 1995.

BARTHES, Roland. A aventura semiológica. Portugal: Edições 70, 1987.

BASTOS, Lúcia, Coesão e coerência em narrativas escolares. São Paulo: Editora da. UNICAMP, 1985.

BAUDRILLARD, Jean. O sistema dos objetos. São Paulo: Perspectiva, 1968.

BEACO, Jean Claude. Analyses de discourse. Paris: Hachette-Larousse, 1984.

BELTRÃO, Luiz; QUIRINO, Newton de Oliveira. Teoria da Comunicação de Massa. São Paulo: Summus, 1986.

BENVENISTE, Emile. Problemas de lingüística geral II. Tradução de Eduardo Guimarães et al. Campinas: Pontes, 1998.

BERGER, John. Modos de ver. Tradução de Ana Maria Alves. São Paulo: Martins Fontes. 1972.

BERMAN, Marshall. Tudo que é sólido desmancha no ar: a aventura da modernidade. Tradução de Carlos F. Moisés e Ana M. L. loratti. São Paulo: Companhia das Letras, 1986.

BHABHA, Homi K. O local da cultura. Tradução de Myriam Ávila, Eliana L. de Lima Reis e Gláucia R. Gonçalves. Belo Horizonte: Editora da UFMG, 1998.

BIEDERMAM, Hans. Dicionário ilustrado de símbolos. Tradução de Glória Pascoal de Camargo. São Paulo: Companhia Melhoramentos, 1943.

BORNHEIM, Gerd (Org.). Cultura brasileira tradições e contradições Rio de Janeiro: Jorge Zahar: Funarte, 1987. 
BOUGNOUX, Daniel. Introdução às ciências da comunicação. Tradução de Maria Leonor Loureiro. São Paulo: EDUSC, 1999.

BOUGNOUX, Daniel. Introdução às ciências da informação e da comunicação. Petrópolis, Rio Janeiro: Vozes, 1994.

BRAGHIROLLI, Elaine Maria (Org.). Psicologia geral. Petropólis, Rio de Janeiro: Vozes, 1999.

BRAIT, Beth (Org.). Bakhtin, dialogismo e construção do sentido. São Paulo: Editora da UNICAMP, 1997.

BRAIT, Beth. Ironia em perspectiva polifônica. Campinas: Editora da UNICAMP, 1996.

BRAIT, Beth. Mikhail Bakhtin: o discurso na vida e na arte. In: DIETZSCH, Mary Julia (Org.). Espaço da linguagem na educação. São Paulo: Humanistas, 1999. p. I I-39.

BRANDÃO, Helena H. Nagamine. Introdução á análise do discurso São Paulo: Editora da. Unesp, 1997.

BRANDÃO, Helena H. Nagamine. Subjetividade, argumentação e polifonia. São Paulo: Editora da Unesp, 1998.

BRANDÃO, Roberto de Oliveira. As figuras de linguagem. São Paulo: Ática, 1989.

BRENER, Jayme. Jornal do século XX. São Paulo: Moderna, 1998.

BROOKSHAW, David. Raça \& cor: na literatura brasileira. Porto Alegre: Mercado Aberto, 1983.

BRONCKART, Jean-Paul. Atividade de linguagem: texto e discursos por um interacionismo sócio-discursivo. Tradução de Ana Rachel Machado P. Cunha. São Paulo: EDUC, 1999.

BRUKE, Peter (Org.). A escrita da história: novas perspectivas. Tradução de Magda Lopes. São Paulo: EDUSP, 1992.

BULIK, Lueda. Doutrinas da informação no mundo de hoje. São Paulo: Loyola Consultec PR-ULL, 1990.

CABRAL, Plínio. Propaganda, técnica da comunicação industrial e comercial. São Paulo: Atlas, 1977.

CADET, C. Charles; GALUS, J. L. La comunication par l'image. Paris: Mathan, 1990.

CALAZANS, F. Propaganda subliminar multimídia. São Paulo: Summus, 1992.

CALDAS, Sônia Regina. Dialogismo e construção de sentido em capas de Gabriela, Cravo e Canela. In: SANTANA NETO, João Antônio de (Org.). Discursos \& Análises. Salvador: UCSAL, 2001.

CALDAS, Sônia Regina. O discurso das capas de Gabriela Cravo e Canela. In: SANTANANETO, João Antônio de (Org.). Discursos \& Análises. Salvador: UCSAL, 2001 .

CALDAS, Sônia Regina. As diversas cores da Gabriela amadiana. In SANTANA NETO, João Antônio de et alii (Org). Discursos em Análises. Salvador UCSAL, 2003.

CALDAS, Sônia Regina. O discurso das capas. In Revista de Cultura e Literaturas dede Língua Portuguesa. Salvador: Empresa Gráfica da Bahia, nI, Jun. 1986. 
CALDAS, Sônia Regina de Araújo; SANTANA NETO, João Antônio de. A feminilidade no anúncio de um cigarro: uma visão semiótica. In: SEMINÁRIO DO CENTRO DE ESTUDOS LINGÜÍSTICOS E LITERÁRIOS DO PARANÁ, 8., I 995, Umuarama, PR. Anais... Umuarama, PR: UNIPAR, 1995, p. 445-449.

CALDAS, Sônia Regina. As capas brasileiras de Gabriela, cravo e canela. In: ALVES, Ivia.(Org). Em torno de Gabriela e Dona Flor. Salvador: Fundação Casa de Jorge Amado, 2004.

CALDAS, Sônia Regina. Os contratos e as capas de Gabriela. In: ALVES, Ivia et alii. (Org). Leituras Amadianas. Salvador: Quarteto/ Casa de Jorge Amado, 2007.

CAMPOS, Haroldo de. Da razão antropofágica. In: Metalinguagem e outras metas. São Paulo: Perspectiva, 1992.

CARMO NETO, Dionísio Gomes. Teoria do metadiscurso. Brasília, D.F.: CNPq, 1997.

CARNEIRO, Agostinho Dias. O discurso da mídia. Rio de Janeiro: Oficina do Autor, 1996.

CASA NOVA, Vera. Lições de Almanaque: um estudo semiótico. Belo Horizonte: Editora da UFMJ, 1996.

CASTRO, E.M. de Melo. O fim do século XX e outros textos críticos. São Paulo: EDUSP, 1993.

CASTRO, Eliana de Moura. Psicanálise e linguagem. 2. ed. São Paulo: Ática, 1992.

CARVALHO, Castelar de. Para compreender Saussure: fundamentos e visão crítica. Petrópolis, Rio de Janeiro: Vozes, 1997.

CARVALHO, Nelly. Publicidade: a linguagem da sedução. São Paulo: Ática, 1996.

CAZENEUVE, Jean. Guia alfabético das comunicações de massa. Tradução de Lucínio Martins et al. São Paulo: Martins Fontes, 1976.

CESAR, Newton. Direção de arte em propaganda. São Paulo: Futura, 2000.

CHABROL, Claude. Semiótica narrativa e textual. São Paulo: Cultrix, 1977.

CHARTIER, Anne-Marie; HEBRARD, Jean. Discursos sobre a leitura. São Paulo: Ática, 1995.

CHATIER, Roger. A aventura do livro: do leitor ao navegador. Tradução de Reginaldo C. C. de Moraes. São Paulo: Editora da UNESP, I 998.

CHAUI, Marilena. Brasil: mito fundador e sociedade autoritária. São Paulo: Editora da Fundação Perseu Abramo, 2000.

CHAUI, Marilena. Convite à Filosofia. São Paulo: Ática, 1998.

CHAUI, Marilena. Cultura e democracia. São Paulo: Cortez, 1993.

CHAUI, Marilena. O que é ideologia? São Paulo: Brasiliense, 1981 .

CHEMANA, Roland (Org.). Dicionário de Psicanálise. Tradução de Francisco F. Settineri. Porto Alegre: Artes Médicas, 1995.

CHEVALIER, Jean; GHEERBRANT, Alain. Dicionário de símbolos: mitos, sonhos, costumes, gestos, 
formas, figuras cores, números. Tradução de Vera da Costa e Silva et al. I 6.ed. Rio de Janeiro: José Olympio, 2001 .

CHIZZOTTI, Antônio. Pesquisa em ciências humanas e sociais. São Paulo: Cortez, I99| .

CLARK, Katerina; HOLQUIST, Michael. Mikhail Bakhtin. Tradução de J. Guinsburg. São Paulo: Perspectiva, 1998.

COELHO, Teixeira. O que é indústria cultural. São Paulo: Brasiliense, 1980.

COLARRO, Antônio Celso. Projeto gráfico, teoria e prática da diagramação. São Paulo: Summus Editorial, 1987.

CONNOR, Steven. Cultura pós-moderna: introdução às teorias do contemporâneo. Tradução de Adail V. Sobral e Maria S. Gonçalves. São Paulo: Loyola, 1993.

BAHIA. Bahiatursa. Comparativo da síntese do perfil do turista nacional e internacional em visita a Salvador em 1995 e 1996. Salvador, 1997.

COMPAGNOM, Antoine. O demônio da literatura: literatura do senso comum. Tradução de Cleonice P. B. Mourão. Belo Horizonte: Editora da UFMG, 1999.

COPAGNON, Antoine. O trabalho da citação. Tradução de Cleonice Mourão. Belo Horizonte: Editora da. UFMG, 1996.

COMUNICAÇÃO \& EDUCAÇÃO. São Paulo: Segmento, ano 7, v. 16, 19, 20, 21 , 2001 .

CORACINI, M.J. Um fazer persuasivo: o discurso subjetivo da ciência. Campinas, São Paulo: EDUC: Pontes, | 1991.

CORRÊA, Roberto. Contato imediato em planejamento em propaganda. São Paulo: Global, 1978.

COULTHARD, Malcom. An introducion to discourse analysis. London: Longman, 1985.

CULLER, Jonathan. Teoria literária: uma introdução. Tradução de Sandra Vasconcelos. São Paulo: Beca, 1999.

CUNHA, Helena Parente. Mulheres inventadas: leituras psicanalíticas de textos na voz masculina. Rio de Janeiro: Tempo Brasileiro, 1994.

CUNHA, Helena Parente (Org.). Desafiando o cânone: aspectos da literatura de autoria feminina na prosa e na poesia (anos70/80). Rio de Janeiro: Tempo Brasileiro, 1999.

CULT - REVISTA BRASILEIRA DE LITERATURA. São Paulo: Lemos, ano 4, n. 40, 45, 46, 2000.

CURTIUS, Ernest Robert. Literatura européia e Idade Média latina. Tradução de Teodoro Cabral e Paulo Ronais. 2.ed. Brasilia: INL, 1979.

DaMATTA, Roberto da. Conta de mentiroso: sete ensaios da antropologia brasileira. Rio de Janeiro: Rocco, 1993.

DaMATTA, Roberto da. Do país do carnaval à carnavalização: o escritor e seus dois Brasis. Cadernos de Literatura Brasileira, São Paulo, Instituto Moreira Salles, n. 3, 1997. 
DASHKÊVITCH, Yuri. Prefácio. Tradução de Olga Belov para uso da pós-graduação do Instituto de Letras da UFBA In: AMADO, Jorge. Gabriela, Cravo e Canela. Moscou: IL, I 96 I.

DEBRAY, Roger. A vida e morte da linguagem. Petrópolis: Vozes, 1994.

DEELY, John. Semiótica básica. São Paulo: Ática, 1990.

DELEUSE, Gilles. Lógica do sentido. Tradução de Luiz R. Salinas Fontes. São Paulo: Perspectiva, 1974.

DERRIDA, Jácques. Gramatologia. São Paulo: Perspectiva, 1972.

DERRIDA, Jaques. A voz e o fenômeno: introdução ao problema do signo na fenomenologia de Hussel. Trad. Lucy Magalhães. Rio de Janeiro: Jorge Zahar, 1994.

DESBORDES, Françoise. Concepções sobre a escrita na Roma antiga. São Paulo: Ática, 1995.

DIJK, Teum van. Estruturas e funciones del discurso. Madrid: Editorial Siglo XXI, I 993.

DIJK, Teun van. Cognição, discurso e interação. São Paulo: Contexto, 1992.

DIRLIK, Arif. A aura pós-colonial: a crítica terceiro-mundista na era do capitalismo global. Tradução de Regina Thompson. Novos Estudos CEBRAP, n. 49, nov. 1997.

DUARTE, Jr., João Francisco. Porque Arte-educação. Rio de Janeiro: Papirus, 1994.

DUARTE, Rodrigo (Org.). Belo, sublime e Kant. Belo Horizonte: Editora da UFMG, 1998.

DUBOIS, Jean. Dicionário de Linguística. Tradução de Izidoro Blikstein. São Paulo: Cultrix, 1973.

DUCROT, Oswald. Dire ne pas dire. Paris: Herman, 1972.

DUCROT, Oswald. O dizer e o dito. Revisão da Tradução de Eduardo Guimarães. Campinas: Pontes, 1987.

DUCROT, Oswald; TODOROV, Tzvetan. Dicionário enciclopédico das Ciências da Linguagem. Tradução de Alice Kyoko Miyashiro et al. São Paulo: Perspectiva, 1972.

DUPEUX, Louis. História cultural da Alemanha (1919-1960). Tradução de Elena Gaidano. Rio de Janeiro: Civilização, 1992.

EAGLETON, Ferry. Ideologia: uma introdução. Tradução de Silvana Vieira e Luiz Carlos Borges. São Paulo: UNESP: Bomtempo, 1997.

ECO, Umberto. A estrutura ausente. São Paulo: Perspectiva, 1997.

ECO, Umberto. Como se faz uma tese. S. Paulo: Perspectiva, 1996.

ECO, Umberto. Conceito de texto. São Paulo: EDUSP, 1984.

ECO, Umberto. Interpretação e superinterpretação. São Paulo: Martins Fontes, 1993.

ECO, Umberto. O signo. Lisboa: Ed. Presença, 1990.

ECO, Umberto. Semiótica e Filosofia da Linguagem. São Paulo: Ática, |991. 
EKERT, Cornélia; MONTE-MOR, Patrícia (Org.). Imagem en foco: novas perspectivas em antropologia. Porto Alegre: Editora da. UFGS, 1999.

EMBALAGEM MARCA - Design, Materiais, Produção, Logística e estratégias para vender. São Paulo: Bloco de Comunicação, ano 3, n. 26, 27, 2001.

ENCICLOPÉDIA UNIVERSO. São Paulo: Delta: Editora 3, 1973. v. I0.

EPSTEIN, Isaac. Gramática do poder. São Paulo: Ática, 1993.

EPSTEIN, Isaac. O signo. São Paulo: Ática, 1991.

ERBOLATO, Mario L. Jornalismo gráfico: técnicas de produção. São Paulo: Loyola, 1981 .

ETKIN, Gustavo E. Uma introdução a Lacan: o real e a metáfora paterna. Salvador: Máthesis, 1996.

FAISSE, Emmanuel; POMPOMGNAC, Jean-Claude; POULAIN, Martine. Representação e imagens da leitura. São Paulo: Ática, 1997.

FANNON, Frantz. Pele negra, máscaras brancas. Tradução de Maria Adriana Caldas. Rio de Janeiro: Fator, 1983.

FARINA, Modesto. Psicodinâmica das cores em publicidade. São Paulo: Edgard Blucher, 1975.

FÁVERO, Leonor; KOCH. Ingedore. Lingüística textual. São Paulo: Cortez, 1983.

FELICIO, Vera Lúcia. A imaginação simbólica nos quatros elementos bachelardianos. São Paulo: EDUSP, 1994.

FERRARA, Lucrécia D'Alessio. A estratégia dos signos. São Paulo: Contexto, 1997.

FERRARA, Lucrécia D'Aléssio. Leitura sem palavras. 3 ed. São Paulo: Ática, 1993.

FERREIRA, Aurélio Buarque de Hollanda. Novo dicionário da língua portuguesa. Rio de Janeiro: Nova Fronteira, 1975.

FERRÉS, Joan. Televisão e educação. Tradução de Beatriz Affonso Neves. Porto Alegre: Artes Médicas, 1996.

FILLMORE, Charles; LANGEDON, T. Studies in linguistic semantics. New York: Holt, Rinehart and Winston, 1971.

FIORIN, José Luiz. As astúcias da enunciação: as categorias de pessoas, espaço e tempo. São Paulo: Ática, 1999.

FIORIN, José Luiz. Elementos de análise do discurso. São Paulo: Contexto, 1990.

FIORIN, José Luiz. Linguagem e ideologia. São Paulo: Ática, 1993.

FIORIN, José Luiz; BAVIOLI, Francisco Platão. Lições de texto: leitura e redação São Paulo: Ática, 1996.

FISCHER, Ernest. Função da Arte. In: VELHO, Gilberto (Org.). Sociologia da Arte. Rio de Janeiro: Zahar, 1966. v.l. 
FISCHER, Tânia (Org.). Carnaval baiano: negócios e oportunidades. Brasilia: Editora Sebrae, 1996.

FONSECA, Maria N. Soares (Org.). Brasil afro-brasileiro. Belo Horizonte: Autêntica, 2000.

FORD, Aníbal. Navegações: comunicação cultura e crise. Tradução de Sergio Alcides e Ronal'd Polito. Rio de Janeiro: Editora da UFRJ, 1999.

FOUCAULT, Michel. A arqueologia do saber. Tradução de L. F. Baeta Neves. Petrópolis: Vozes, |97|.

FOUCAULT, Michel. História da sexualidade: a vontade de saber. Tradução de Maria T. da Costa Albuquerque e J G. de Albuquerque. Rio de Janeiro: Graal, 1977.

FOUCAULT, Michel. Microfisica do poder. Tradução de Roberto Machado. Rio de Janeiro: Graal, 1979.

FRAGA, Myriam. Bahia a cidade de Jorge Amado: ciclo de palestras. Salvador: Editora da FCJA, 2000.

FRANCASTEL, Pierre. Imagem: visão e imaginação. Tradução de Fernando Caetano. São Paulo: Martins Fontes, 1993.

FREITAS, Lívia de et al. (Org.). Anais do VIl Seminário Nacional Mulheres e Literatura. Rio de Janeiro: EDUFF, 1999.

FREITAS, Maria Tereza. Vygotsky e Bakhtin. São Paulo: Ática, 1995.

FREITAS, Maria Teresa. Vigotsky e Bakhtin: psicologia e educação: um intertexto. São Paulo: Ática, 1995.

FREYRE, Gilberto. O brasileiro entre os outros hispanos: afinidades, contrastes e possíveis futuros nas suas inter-relações. Rio de Janeiro: José Olympio, 1975.

FREYRE, Gilberto. Talvez poesia. Rio de Janeiro: José Olympio, 1962.

FRISCH, Johan Dalgas. Aves brasileiras. São Paulo: Dalgas, 1981.

FRUTIGER, Adrian. Sinais e símbolos: desenho e significado. São Paulo: Martins Fontes, 1999.

GABEIRA, Fernando. Caminhos nordestinos do turismo sexual. Folha de S. Paulo, p.0, 3 set. 2001 .

GADE, Cristiane. Psicologia do consumidor. São Paulo: EPU, 1980.

GARCIA CANCLINI, Néstor. Consumidores e cidadãos: conflitos multiculturais da globalização. Rio de Janeiro: Editora da UFRJ, 1999.

GARCIA CANCLINI, Néstor. Culturas híbridas: estratégia para entrar e sair da modernidade. Tradução de Ana Regina Lessa e Heloisa Pezza Cintrão. São Paulo: EDUSP, 1998.

GARDNER, Howard. As artes e o desenvolvimento humano. Tradução de Maria V. Veronese. Porto Alegre: Artes Médicas, 1997.

GAY, Peter. O estilo da história: Gibbon, Ranke, Macaulay, Burckhaedt. Tradução de Denise 
Bottmann. São Paulo: Companhia das Letras, 1990.

GERALDI, W; ILARI, R. Semântica. São Paulo: Ática, 1985.

GIRAUD, Pierre. A linguagem do corpo. São Paulo: Ática, | 99 | .

GOETHE, J. W. Doutrina das cores. Tradução de Marco Giannotti. 2. ed. São Paulo: Nova Alexandria, 1996.

GOFMAM, Erving. A representação do eu na vida cotidiana. Tradução de Maria Célia Santos Raposo. Petrópolis: Vozes, 1989.

GREIMAS, Algirdas J.; FONTANILLE, J. Semiótica das paixões: dos estados de coisas aos estados de alma. Tradução de Maria José Rodrigues Coracini. São Paulo: Ática, 1991 .

GREIMAS, Algirdas J. Semiótica do discurso científico. São Paulo: Difel, 1976.

GRUNIG, Blanche. Les mots de la publicité: I' architeture du slogan. Paris: Presses du CNRS, 1990.

GUARESCHI, Pedrinho A. (Coord.). Comunicação e controle social. Petrópolis: Vozes, 1991 .

GUIMARÃES, Eduardo (Org.). História e sentido na linguagem. Campinas: Pontes, 1989

GUIMARÃES, Eduardo. Texto e argumentação. Campinas: Pontes, 1983.

GUIMARÃES, Luciano. A cor como informação: a construção biofísica, lingüística e cultural da simbologia das cores. São Paulo: Annablume, 2000.

GULLAR, Ferreira. Arte brasileira hoje. Rio de Janeiro: Paz e terra, 1973.

HALPERIN DONGHI, Túlio. Historia contemporanea de América Latina. I3. ed. Madrid: Ed. Alianza, 1993.

HALL, Stuart. A identidade cultural da pós-modernidade. Tradução de Tomaz T. da Silva e Guacira L. Louro. Rio de Janeiro: DPA, 2000.

HALLIDAY, M.A.K. Exploraciones sobre funciones del lenguage. Barcelona: Ed. Médica y Técnica, 1982.

HAYAKAWA, S. I. A linguagem no pensamento e na ação. Tradução de Oliveira Krähenbilhe. São Paulo: Pioneira, 1972.

HISTÓRIA do Século XX. São Paulo: Abril, 1975.

HISTÓRIA llustrada do Século XX. São Paulo: Folha da Tarde, 1996.

HOBSBAWM, Eric. Era dos Extremos (1914-1991). São Paulo: Cia das Letras, 1994.

HOBSBAWM, Eric; RANGER, Terence. A invenção das tradições. Tradução de Celena Cardin Cavalcante. Rio de Janeiro: Paz e Terra, 1999.

HUYGHE, R. O poder da linguagem. Tradução de Helena Leonor Santos. São Paulo: Martins Fontes, 1986. 
IMPRENSA E MÍDIA. São Paulo: Editorial, ano 3, n. 33/34, 1997.

JAKUBASKO, Richard. Marketing rural como se comunicar com o homem que fala com Deus. São Paulo: Best Seller, 1992.

JAMESON, Fredric. Espaço e imagem: teorias do pós-moderno e outros ensaios. Tradução de Ana L. A Gazolla. Rio de Janeiro: Editora da UFRJ, 1994.

JAMESON, Fredrich. As marcas do visível. Tradução de Ana Lucia de A. Gazzolla, Aparecida Silva Regina Thompson e Roneide V. Majerl. Rio de Janeiro: Graal, 1995.

JAQUES, João Pedro. Tipografia pós-moderna. Rio de Janeiro: 2AB, 1998.

JOBIN, J. L. (Org.). Palavras da crítica. Rio de Janeiro: Imago, 1993.

KATO, M. No mundo da escrita. São Paulo: Ática, 1986.

KATO, M. O aprendizado da leitura. São Paulo: Martins Fontes, 1990.

KLEIMAN, Ângela. Leitura e pesquisa. Campinas: Pontes, 1989.

KLEIMAN, Ângela. Oficina da leitura. Campinas: Pontes, 1983.

KOCH, Ingedore. A coesão textual. São Paulo: Contexto, 1991 .

$\mathrm{KOCH}$, Ingedore. A interação pela linguagem. São Paulo: Contexto, 1997.

$\mathrm{KOCH}$, Ingedore. Argumentação e linguagem. São Paulo: Cortez, 1987.

KOCH, Ingedore. Texto e coerência. São Paulo: Cortez, 1989.

LAGAZZI, Suzy. O desafio de dizer não. Campinas: Pontes, 1988.

LAJOLO, Marisa. Do mundo da leitura para a leitura do mundo. São Paulo: Ática, 1993.

LA REVISTA - Jornal de El Mondo. España, n. 89, jun. 1997.

LAKATOS, Eva Maria; MARCONI, Marina de Andrade. Metodologia do trabalho científico. São Paulo: Atlas, 1992.

LAPLANCHE, J.; PONTALIS, J. Vocabulário da Psicanálise. Tradução de Pedro Tamem. 3.ed. São Paulo: Martins Fontes, 1998.

LEGRAIN, Mário; MAGAIN, Daniel. Promoção de vendas. São Paulo: Makron Books, 1992.

LEITE, Dante M. O caráter nacional. São Paulo: Ática, 1992.

LEITE, Mirian L. M. Livros de viagem. Rio de Janeiro: Editora da UFRJ, 1997.

LEITE, Nina. Psicanálise e análise do discurso. Rio de Janeiro: Campo Matemático, 1994.

LEVI-STRAUSS, Claude. Antropologia estrutural. Rio de Janeiro: Tempo Brasileiro, 1987.

LOPES, Edward. A identidade e a diferença. São Paulo: EDUSP, 1997.

LOPES, Edward. Discurso, texto e significação. São Paulo: Cultrix, 1978.

LOZANO, J.et al. Análisis del discurso. Madrid: Ed. Cátedra, 1982. 
LUCAS, Meize Regina de Lucena. Imagem do moderno: $O$ olhar de Jaques Tati. São Paulo: Anna Bule, 1998.

LUZ, Ana Maria de C. (Org.). Quem faz Salvador? Salvador: UFBA, 2002.

MACHADO, Roberto. Ciência e saber: a trajetória da arqueologia de Foucault. Rio de Janeiro: Graal, 1981.

MADRUGA, G. et al. Comprensión y adquisición de conocimientos a partir de textos. Madrid: Ed. Siglo XXI, 1995.

MAGALHÃES, Belmira. Uma análise da representação de gênero na literatura brasileira contemporânea. Revista Exu, Salvador, FCJA, n.35, 1997.

MAINGUENEAU, Dominique. Análise do discurso. Campinas: Pontes, 1989.

MAINGUENEAU, Dominique. Analyse des textes de comunication. Paris: Dumod, 1998.

MAINGUENEAU, Dominique. Elementos de lingüística para o texto literário. São Paulo: Pontes, 1996.

MAINGUENEAU, Dominique. Termos-chave da Análise do Discurso. Tradução de Márcio Barbosa e Maria E. Lima. Belo Horizonte: Editora da UFMG, 1998.

MANUAL de Redação: Folha de São Paulo. São Paulo: Publifolha, 2001 .

MARC, Legrain. Promoção de vendas. São Paulo: Makron Books, 1992.

MARCONDES FILHO, Ciro. Comunicação e Jornalismo: a saga dos cães perdidos. São Paulo: Hacher, 2000.

MARCONDES FILHO, Ciro. Política e imaginário nos meios de comunicação para massa no Brasil. São Paulo: Summus, 1985.

MARCONDES FILHO, Ciro. Quem manipula quem? Petrópolis: Vozes, 1991.

MARCUSCHI, L. A. Análise da conversação. São Paulo: Ática, | 99 | .

MARTIN-BARBERO, Jesús. Dos meios às mediações: comunicação cultura e hegemonia. Tradução de Ronald Polito e Sérgio Alcides. Rio de Janeiro: Editora da UFRJ, 1997.

MARTIN-BARBERO, Jesús. Os exercícios de ver: hegemonia audiovisual e ficção televisiva. Tradução de Jacob Gorender. São Paulo: Ed. Senac, 2001 .

MARTINS, Wilson. A palavra escrita: história do livro da imprensa e da biblioteca. São Paulo: Ática, 1996.

MASSIRONI, M. Ver pelo desenho. Tradução de Cláudia de Brito. São Paulo: Martins Fontes, 1982.

MERTEN. Luiz Carlos. Cinema: um zaping de Lumiére a Tarantino. Porto Alegre: Artes e Ofícios, 1995.

MESTRINER, Fábio. Design de embalagem: curso básico. São Paulo: Makron Books, 2001 . 
MESTRINER, Fábio. Design de embalagem: curso avançado. São Paulo: Pearson Education Brasil, 2002.

MIÉGE, Bernard. La societé conquise par la communication. France: Pug, 1989.

MIGNOLO. Walter. La razón postcolonial: herencias coloniales y teorías postcolniales. Gragoatá, Feira de Santana, UEFS, n. I , 1996.

MORIN, Edgard. Cultura de massa no século XX. 9.ed. Rio de Janeiro: Forense Universitária, 1997.

MOSCA, Lineide do Lago Salvador (Org.). Retóricas de ontem e de hoje. São Paulo, Humanista: USP, 1997.

MUNARI, Bruno. Design e comunicação visual. Tradução de Daniel Santana. São Paulo: Martins Fontes, 1968.

NACHMANOVICH, Stephem. Ser criativo: o poder da informação na vida e na arte. São Paulo: Summus, 1994.

NASCIMENTO, Evandro. Derrida e a literatura: notas de literatura e filosofia nos textos da desconstrução. Niteroi: EDUFF, 1999.

NEIVAJr., Eduardo. A imagem. São Paulo: Ática, 1986.

NETTO, Samuel Fromm. Tecnologia da comunicação de massas. São Paulo: Pioneira, 1932.

NEWTON, I. Óptica. São Paulo: Edusp, 1996.

NÖTH, Winfied. A semiótica do século XX. São Paulo: Annablume, 1996.

NOVAES, Adauto (Org.). Rede imaginária: televisão e democracia. São Paulo: Companhia das Letras, |99|.

NUNES FILHO, Pedro. Cinema e poética. Maceió: Trilha Editorial, 1993.

NUNES, Benedito. A filosofia contemporânea: trajetos iniciais. São Paulo: Ática, 199| .

OECH, Roger von. Um toc na cuca: técnicas para quem quer ter mais criatividade na vida. São Paulo: Livraria Cultura, 1988.

OKASABE, Haquira. Argumentação e discurso político. São Paulo: Kairos, 1979.

OLINTO, Heidrum. Histórias de literatura: as novas teorias alemãs. São Paulo: Ática, 1996.

OLIVEIRA, Ana C.; FECHINE, Yomar. Semiótica da arte: teorizações, análises e ensino. São Paulo: Hacker, 1998.

ORLANDI, Eni Pucinetti. Interpretação: autoria, leitura e efeitos do trabalho simbólico. 2. ed. Petrópolis: Vozes, 1996.

ORLANDI, Eni P. (Org.). Gestos de leitura: da história no discurso. Campinas: Unicamp, 1994.

ORLANDI, Eni P. (Org.). Palavra, fé e poder. Campinas: Pontes, 1987.

ORLANDI, Eni P. A linguagem e seu funcionamento. Campinas: Pontes, 1987. 
ORLANDI, Eni P. As formas do silêncio. Campinas: Unicamp, 1995.

ORLANDI, Eni P. Discurso e leitura. São Paulo: Cortez, 1993.

ORLANDI, Eni P. Discurso fundador. São Paulo: Cortez, 1993.

ORLANDI, Eni P. Discurso indígena. Campinas: Editora da Unicamp, | 991.

ORLANDI, Eni P. et al. Leitura, perspectivas interdisciplinares. São Paulo: Ática, 1991.

ORLANDI, Eni P. Língua e cidadania. Campinas: Pontes, 1996.

ORLANDI, Eni P. Terra à vista. Campinas: Cortez, 1990.

ORTIZ, Renato. A moderna tradição brasileira: cultura brasileira e indústria cultural. São Paulo: Brasiliense, 1995.

PAGLIARO, Antônio. A vida do sinal. Tradução de Cenibal Pinto de Castro. Lisboa: Ed. Fundação Calouste Gulbekian, 1952.

PAIVA, Vera Lucia Meneses (Org.). Metáforas do cotidiano. Belo Horizonte: Editora da UFMG, 1998.

PALMER, F.R. Semantics. Cambridge: Cambridge University Press, 1976.

PALMER, Richard. Hermenêutica. Rio de Janeiro: Edições 70, 1989.

PARENTE, André. Imagem máquina. Rio de Janeiro: Editora 34, 1993.

PATRÍCIO, Rosana. R. Imagens de mulher em Gabriela de Jorge Amado. Salvador: Editora da FCJA, 1999.

PAULINO, Graça et al. Intertextualidades. Belo Horizonte: Lê, 1995.

PEASE, Allan. A linguagem do corpo: como entender as mensagens dos outros pelos gestos. Tradução de Lia Faleck. Rio de Janeiro: Record, 1995.

PÊCHEUX, Michel. O discurso. Campi-nas: Pontes, 1990.

PÊCHEUX, Michel. O discurso: estrutura ou acontecimento. Tradução de Eni P. Orlandi. Campinas, 1990.

PÊCHEUX, Michel. Semântica e discurso. Campinas: Unicamp, 1988.

PEDREIRA, Lícia. Gabriela e os filhos de Calvino: uma leitura da versão de Gabriela, Cravo e Canela em língua inglesa. 200 I . Dissertação (Mestrado em Letras)-Instituto de Letras, Universidade Federal da Bahia, 200I . Área de Estudos Culturais.

PEDROSA, Israel. Da cor à cor inexistente. Rio de Janeiro: Léo Cristiano Editorial, 1982.

PENTEADO, J. R. Whitaker. A técnica da comunicação humana. 13.ed. São Paulo: Pioneira, 1997.

PEREIRA, Carlos M. P.; NETO, Antônio F. (Org.). Comunicação e cultura contemporâneas. Rio de Janeiro: Nortrya, 1993. 
PERELMAM, C.H.; TYTECA-OLBRECTS, L. Tratado da argumentação: a nova Retórica. Tradução de Maria Ermantina Galvão Pereira. São Paulo: Martins Fontes, 1996.

PERETTI, Cristina. Jacques Derrida, texto y deconstrucción. Barcelona: Editorial Anthropos, 1989.

PERUZZO, Cicília M. K.; ALMEIDA, Fernando F. de A. A mídia impressa. In: . O livro e as tecnologias. São Paulo; Intercom: Uniderp, 2002.

PETRI, Maria José Constantino. Argumentação lingüística e discurso jurídico. São Paulo: Selinunte, 1994.

PICCHIO, Lucciana. História da literatura brasileira. Tradução de Pérola Carvalho e Alice Kyoko. Rio de Janeiro: Nova Aguilar, 1997.

PIGNATARI, Décio. Semiótica e literatura: econômico e verbal, Oriente e Ocidente. São Paulo: Cortez: Moraes, 1979.

PINHO, I.B. (Org.). Trajetória e questões Contemporâneas da publicidade brasileira. São Paulo: Intecom, 1995.

PLEBE, A.; EMANUELE, P. Manual de retórica. São Paulo: Martins Fontes, 1992.

PONTES, Eunice. Sujeito da sintaxe ao discurso. São Paulo: Ática, 1986.

POSSENTI, Sírio. Discurso, estilo e subjetividade. São Paulo: Martins Fontes, 1993.

PRADO Jr., Caio. História econômica do Brasil. I8. ed. São Paulo: Brasiliense, 1976.

PRESSCOTT, Orville. Books of the times. The New York Times, New York, Sept. 12, 1962.

PRIORE, Mary del (Org.). História das mulheres no Brasil. São Paulo: Contexto, 2001.

PROUST, Marcel. Sobre a leitura. São Paulo: Pontes, 1991.

PRYSTHON, Ângela (Org.). Interferências contemporâneas: comunicação, estudos culturais e pós-moderno. Recife: Bagaço, 2002.

RABAÇA, Carlos Alberto; BARBOSA, Gustavo. Dicionário de Comunicação. Rio de Janeiro: Codecri, 1978.

RAILLARD, Alice. Conversando com Jorge Amado. Tradução de Dymetman. Rio de Janeiro: Record, 1990.

RAMOS, Fernão (Org.). História do cinema brasileiro. São Paulo: Círculo do livro, 1987.

RAMOS, José Mário Ortiz. Televisão, publicidade e cultura de massa. Petrópolis: Vozes, 1995.

RANDAZZO, Sal. A criação dos mitos na publicidade: como os publicitários usam o poder do mito para criar marcas de sucesso. Tradução de Mário Fondelli. Rio de Janeiro: Rocco, 1996.

RANTER, Carl. A psicologia sócio-histórica de Vigotsky: aplicações contemporâneas. Tradução de Lólio Lourenço de Oliveira. Porto Alegre: Artes Médicas, 1995.

READ, Herbert. Arte e alienação, o papel do artista na sociedade. Tradução de Hames and Hudson. Rio de Janeiro: Zahar, 1983. 
RECTOR, Mônica; TRUILA, Aluizio Ramos. Comunicação do corpo. São Paulo: Ática, 1990.

REIS, Carlos. Técnicas de análise textual 3. Coimbra: Liv. Almedina, 1981.

REIS, Roberto. A redoma e o bumerangue: assédio à cultura brasileira: Brazil Brasil, ano 8, n. I3, 1998.

REIS, Roberto. Por sobre os ombros: leituras do discurso cultural brasileiro. Rio de Janeiro: Editora da UFRJ, 1995.

REVISTA BRASILEIRA DE CIÊNCIAS DE COMUNICAÇÃO. São Paulo: Intercom, v. | 8, n. I, 2000.

REVISTA DO CHAME. Salvador: Chame - Centro Comunitário de Apoio à Mulher, 1998.

REVISTA DA FAEEBA. Salvador: Departamento de Educação I/UNEB, ano I , n. I , 1992.

RIBEIRO, Gustavo Leris. A condição da transnacionalidade. Brasília: Editora da Universidade de Brasília, 1997.

RIBEIRO, Milton. Planejamento visual gráfico. Brasília: Linha Gráfica e Editora, 1987.

RICOEUR, Paul. El discurso de la acción. Madrid: Ed. Cátedra, 1988.

RICOEUR, Paul. Interpretação e ideologias. Tradução de Francisco Alves. Rio de Janeiro: Graal, 1990.

RINALDI, Doris. A ética da diferença: um debate entre psicanálise e antropologia. Rio de Janeiro: Jorge Zahar: Editora da UFRJ, 1996.

ROCHA, Carlos de Sousa; NOGUEIRA, Mario Marcelo. Panorama das artes gráficas. Lisboa: Plátano Edições Técnicas, 1993.

ROCHA, E.P.G. Magia e Capitalismo: um estudo antropológico da publicidade. São Paulo: Brasiliense, 1984.

ROCHA, Everardo. O que é o mito. São Paulo: Brasiliense, 1996.

RODRIGUES, Urbano T. Gabriela, cravo e canela: um novo mito brasileiro. Diário de Lisboa, Portugal, 8 out. 1958.

ROLLEMBERG, Vera (Org.). Um Grapiuna no país do carnaval: Atas do Simpósio Internacional de Estudos Jorge Amado. Salvador: Ed. FCJA-EDUFBA, 2000.

RORTY, Richard. Pragmatismo: a filosofia da criação e da mudança. Tradução de Cristina Magro e Antônio M. Belo Horizonte: Ed. UFMG, 2000.

ROSA, Margaret. Marcadores de atenuação. São Paulo: Contexto, 1992.

RUFINO TAMAYO. Bibliografia. Disponível em: < http://www.sol jaguar.com.mx/articles/l 899 199 l ing.htm >. Acesso em: I ${ }^{\circ}$ maio, 2000.

RUIZ, João Álvaro. Metodologia científica. São Paulo: Atlas, 1966.

SACHS, Sheldon (Org.). Da metáfora. Campinas: Pontes, 1992. 
SAFFIOTI, Heleieth I. B. O poder do macho. São Paulo: Moderna, 1987.

SAID, Edward W. Cultura e Imperialismo. Tradução de Denise Bottmam. São Paulo: Companhia das Letras, 1990.

SAID, Edward W. Orientalismo: o Oriente como invenção do Ocidente. Tradução de Tomás R. Bueno. São Paulo: Companhia das Letras, 1995.

SAMPAIO, Aluysio M. Jorge Amado, o romancista. São Paulo: Mattese, 1996.

SANT'ANNA, Affonso Romano de. O canibalismo amoroso. Rio de Janeiro: Rocco, 1993.

SANTANA NETO, João Antônio de. Semióticas: verbal e não-verbal. Revista de Letras, Alagoinhas, UNEB-FFPA, n. 5, p.24-29, 1995.

SANTAELLA, Lucia. O que é semiótica. São Paulo: Brasiliense, 1985.

SANTIAGO, Silviano. Nas malhas da letra. São Paulo: Companhia das Letras, 1990.

SANTIAGO, Silviano. Uma literatura nos trópicos. São Paulo: Perspectiva, 1978.

SANTIAGO, Silviano. Vale quanto pesa. Rio de Janeiro: Paz e Terra, 1982.

SANTOS, Jair Ferreira. O que é pós-moderno. São Paulo: Brasiliense, 1986.

SANTOS, José Luiz dos. O que é cultura. São Paulo: Brasiliense, 1992.

SCHIMIDT, J. Siegrried. Lingüística e teoria de texto. São Paulo: Pioneira, 1978.

SCHULER, Donaldo. Teoria do romance. São Paulo: Ática, 1989.

SCHWARZ, Roberto. O pai de família e outros estudos. 2. ed. São Paulo: Paz e Terra, 1992.

SEIXAS, Cid. Triste Bahia. Oh! quão dessemelhante: notas sobre a literatura da Bahia. Salvador: EGBA, 1996.

SEVERINO, Antônio Joaquim. Metodologia do trabalho científico. São Paulo: Cortez, 1993.

SKIDMORE, Thomas. De Getúlio a Castelo. 5. ed. Rio de Janeiro: Paz e Terra, 1976.

SILVA, Ezequiel da. $O$ ato de ler: fundamentos para uma nova pedagogia da leitura. São Paulo: Cortez, 1984.

SILVA, Rafael Souza. Diagramação: o planejamento visual gráfico na comunicação impressa. São Paulo: Summus, 1985.

SILVA, Tomaz Tadeu da (Org.). Identidade e diferença: a perspectiva dos estudos culturais. Petrópolis: Vozes, 2000.

SILVERMANN, Malcolm. Moderna ficção brasileira: ensaios. Rio de Janeiro: Civilização Brasileira, 1990.

SIMÕES, EddaA. Quirino; TIEDEMENN, Klaus B. Psicologia da percepção. São Paulo: EPU, 1985.

SITYA, Celestina V. Moraes. A lingüística textual e a análise do discurso: uma abordagem interdisciplinar. Rio Grande do Sul: URI, 1995. 
SODRÉ, Muniz. Televisão e psicanálise. São Paulo: Ática, 1987.

SOUSA, Mauro Wilton de (Org.). Sujeito: o lado oculto do receptor. Tradução de Silvia Cristina Dolta e Kiel Pimenta. São Paulo: Brasiliense, 1995.

STAM, Robert. Bakhtin: da teoria à cultura de massa. São Paulo: Ática, 1992.

TAHARA, Mizuno. Contato imediato com a midia São Paulo: Global, 1998.

TANNEN, Deborah. Coherence in spoken and written discourse. New Jersey: Ablex, 1984.

TANNEN, Deborah. Spoken and written language. New Jersey: Ablex, 1982.

TEIXEIRA, Lúcia. As cores do discurso. Niterói: EDUFF, 1996.

TERRARA, Lucrécia D’Alessio. A estratégia dos signos. São Paulo: Pespectiva, 198 I.

THOMPSOM, John B. A mídia e a modernidade: uma teoria social da mídia. Petrópolis: Vozes, 1998.

TOSCANI, Oliviero. A publicidade é um cadáver que nos sorri. 2. ed. Rio Janeiro: Ediouro, 1996.

VALENTE, André. A linguagem nossa de cada dia. Petrópolis: Vozes, 1997.

VAZ, Gil. Marketing turístico: receptivo e emissivo: um roteiro estratégico para projetos mercadológicos públicos e privados. São Paulo: Pioneira, 1999.

VEIGAS, Waldyr. Fundamentos da metodologia científica. Brasília: Universidade de Brasília, 1990.

VENUTI, Lawrence. Scandals of translalion. London: New York: Routledge, 1998.

VIEGAS, Waldyr. Fundamentos de metodologia cientifica. Brasília: Universidade de Brasília, 1999.

VILLAS BOAS, André. Utopia e disciplina. Rio de Janeiro: 2AB, 1998.

VOGT, Carlos. Linguagem, pragmática e ideologia. São Paulo: Hucitec, 1980.

WALTY, Saete L. C. Palavra e imagem: culturas cruzadas. Tradução de Maria N.S. Fonseca e Maria Z. F. Cury. Belo Horizonte: Autêntica, 2000.

WATZLAWICK, P. et al. Pragmática da comunicação humana. São Paulo: Cultrix, 1967.

WESTERGARD, Torben; SCHRODER, Kim. A Linguagem da propaganda. Tradução de João Alves dos Santos. São Paulo: Martins Fontes, 1988.

WOLF, Mauro. Teorias da comunicação. Tradução de Maria Jorge Velar Figueredo. Lisboa: Editorial Presença, 1994.

ZIBERMAN, R.; SILVA, E.T. da. Leitura: perspectivas interdisciplinares. São Paulo, Ótica: 1988.

ZUMTHOR, P. A letra e a voz. São Paulo: Companhia das Letras: 1993. 
Colofão

\begin{tabular}{|c|c|}
\hline Formato & $19,2 \times 23,4 \mathrm{~cm}$ \\
\hline Tipologia & $\begin{array}{l}\text { DeVinne BT, Hmanst52 I LtBT, } \\
\text { Hmanst52tBT }\end{array}$ \\
\hline Papel & $\begin{array}{l}\text { Couchê fôsco II } 15 \mathrm{~g} / \mathrm{m}^{2} \text { (miolo) } \\
\text { Triplex } 250 \mathrm{~g} / \mathrm{m}^{2} \text { (capa) }\end{array}$ \\
\hline Impressão & Gráfica Santa Marta \\
\hline Tiragem & 600 exemplares \\
\hline
\end{tabular}

